UNIVERSIDADE DE SÃO PAULO

FACULDADE DE FILOSOFIA, CIÊNCIAS E LETRAS DE RIBEIRÃO PRETO

DEPARTAMENTO DE FÍSICA

PROGRAMA DE PÓS-GRADUAÇÃO EM FÍSICA APLICADA À MEDICINA E BIOLOGIA

PRISCILLA FREDDI

\title{
Interações moleculares no mecanismo de ação de peptídeos de fusão e complexos metálicos de interesse farmacológico
}

Tese apresentada ao Programa de Pós-Graduação em Física Aplicada à Medicina e Biologia da Faculdade de Filosofia, Ciências e Letras de Ribeirão Preto da Universidade de São Paulo, para a obtenção do título de Doutora em Ciências.

Ribeirão Preto 



\section{PRISCILLA FREDDI}

\section{Interações moleculares no mecanismo de ação de peptídeos de fusão e complexos metálicos de interesse farmacológico}

Tese apresentada ao Programa de Pós-Graduação em Física Aplicada à Medicina e Biologia da Faculdade de Filosofia, Ciências e Letras de Ribeirão Preto da Universidade de São Paulo, para a obtenção do título de Doutora em Ciências.

Orientador; Antonio José da Costa Filho

Co-orientador: Eduardo Feztoso Vicente 
AUTORIZO A REPRODUÇÃO E DIVULGAÇÃO TOTAL OU PARCIAL DESTE TRABALHO, POR QUALQUER MEIO CONVENCIONAL OU ELETRÔNICO, PARA FINS DE ESTUDO E PESQUISA, DESDE QUE CITADA A FONTE.

\section{FICHA CATALOGRÁFICA}

Freddi, Priscilla

Interações moleculares no mecanismo de ação de peptídeos de fusão e complexos metálicos de interesse farmacológico / Priscilla Freddi; Orientador Antonio José da Costa Filho; Co-orientador Eduardo Festozo Vicente - Ribeirão Preto, 2018

150 p.: il.; $30 \mathrm{~cm}$

Tese (Doutorado em Ciências) - Programa de Física Aplicada à Medicina e Biologia, Faculdade de Filosofia, Ciências e Letras de Ribeirão Preto, Universidade de São Paulo, Ribeirão Preto, 2018

Versão corrigida

1. Peptídeo de fusão da Dengue 2. Complexos metálicos 3. Cobre 4. Membrana-modelo 5. Espectroscopia I. Costa-Filho, Antonio José, orient. II. Título 
Dedico esta tese ao meu marido Luís Felipe

"Pra você guardei o amor que aprendi vendo os meus pais. $O$ amor que tive e recebi E hoje posso dar livre e feliz."

Nando Reis 



\section{AGRADECIMENTOS}

Agradeço a todos aqueles que contribuíram de forma direta e indireta para a realização deste projeto. Em especial:

Ao meu orientador Antonio José da Costa Filho, Jabah. Obrigada pela oportunidade e confiança dadas a mim. Por todo o ensinamento e paciência em todos esses anos de orientação.

Ao meu co-orientador Eduardo Festozo Vicente, Lentilha. Obrigada por toda a ajuda deste a preparação deste projeto, além dos ensinamentos, conversas e amizade.

A todos os colegas que fazem e fizeram parte do Laboratório de Biofísica Molecular nesses quase 8 anos, entre mestrado e doutorado, pela colaboração cientifica, conversas do dia-a-dia e todos os momentos em que sempre seguimos à risca o nosso famoso lema "work hard, party hard". Em especial ao Assuero, Rafael, Paty e Militar por toda a ajuda ao longo dos anos. Haroldo (compadre), por todas as conversas e pelas horas de "bolo no Valter" pra desestressar (sempre com fofocas), à Natália por me abrigar sempre que eu precisei! Além do pessoal da salinha mais legal do DF: Éder, Sudi, Ana Helena e Haroldo, pelas fofocas e bate-papo na hora da preguiça da tarde! Enfim, a todo pessoal do DF e agregados que fizeram parte da minha história esses anos todos.

Ao Danilo, pelas conversas, ajuda e dicas e pelas simulações por dinâmica molecular que contribuíram com a finalização desta tese.

À Prof.(a) Dr(a) Gianella Facchin da Universidade de La Republica do Uruguai, por ter cedido os complexos estudados nesta tese e por toda a ajuda desde meu mestrado.

À Natália por toda a ajuda e parceria nos estudos dos complexos, além de todas as conversas regadas à cerveja e gordices! 
Ao Prof. Dr. Eduardo Cilli, do IQ da UNESP/Araraquara, por ter cedido os peptídeos de estudo desta tese, além de abrir as portas de seu laboratório para mim e das conversas e ensinamentos a mim concedidos.

Aos colegas do IQ/UNESP, Esteban, Norival, Crusca, por toda a ajuda no processo da síntese dos peptídeos, e em especial à Julia (a mais nova "co-co-orientadora" da história) por toda a ajuda, conversas e ombros para eu chorar quando algo que não tinha como dar errado, dava!

Aos colegas da Biofísica do IFSC/USP, obrigada por todas as boas conversas nos momentos de café; em especial ao Wesley e Paty pela companhia dos almoços. E aos técnicos, Bel, Andressa e Fernando, por toda a ajuda, resolvendo sempre prontamente todos os nossos problemas, além de me cederem um cantinho para chamar de meu e me sentir parte do laboratório.

Ao Prof. Dr. Otaciro Nascimento por ceder o equipamento de EPR para as medidas.

Ao Prof. Dr. Pietro Ciancaglini por ceder o equipamento de DSC, onde realizei meus testes iniciais do doutorado.

Ao Prof. Dr. Amando Ito por ceder o fluorímetro, além da ajuda e discussões.

A todos os amigos que conquistei ao longo da vida, na universidade e fora dela, aos amigos de infância sempre presentes, aos amigos que agora são compadres de casamento, que talvez nunca leiam esse agradecimento, mas gostaria de registrar o meu muito obrigada, sem vocês já seria a "física louca" que vocês tanto brincam que eu vou virar um dia. Em especial, às amigas, aquelas que me ouvem a toda hora, inclusive em crises de madrugada hehe e sempre estão prontas pros conselhos, broncas e o que eu precisar, Marissol e Lulu (vou deixar o apelido sim, porque é assim que vou sempre me lembrar de vocês). E Marissol, vou deixar registrado aqui, pra ser eterno, que venha a trilogia!

Deixo mais para o fim, por serem os mais importantes e mais difíceis de agradecer, já que sem o apoio e amor deles não chegaria até este momento da minha vida: agradeço aos meus pais por todo o apoio, emocional e financeiro, ao longo de todos esses anos, que 
mesmo sendo um caminho tão diferente da vida de vocês, nunca me disseram para desistir. À minha irmã, Pércia, obrigada por toda as conversas, companheirismo e gordices que me proporciona! Amo vocês!

À toda a minha família, em especial às minhas avós Anna e Teresa (in memoriam), que sempre torceram por mim, rezando pelas minhas conquistas.

Além da família que não "veio de nascença", mas que escolhi, em especial aos cunhadinhos Carol, Davi, Matheus e Nana, que estão sempre presentes. E Miguel e Alice que são meus amorecos e nem tem idade para ler isso, mas quem sabe um dia decidem ler sobre física e param nesta tese hehe

Por último e o mais importante, agradeço ao meu marido, Luís Felipe, por todo o apoio e paciência, por sempre acreditar em mim, mesmo quando eu não acredito, por ser essa pessoa que me impulsiona a ser sempre melhor, por estar sempre por perto, mesmo a quilômetros de distância. Que esse ano casados, cada um em um hemisfério, seja só um ano que contaremos no futuro com orgulho, de "que deu certo e valeu a pena". E o meu mais profundo obrigada pelo Tycho e Lisa, minha vida é mais colorida agora!

À Faculdade de Filosofia, Ciências e Letras de Ribeirão Preto.

À CAPES (O presente trabalho foi realizado com apoio da Coordenação de Aperfeiçoamento de Pessoal de Nível Superior - Brasil (CAPES) - Código de Financiamento 001), FAPESP e CNPq pelo apoio financeiro fundamental para a realização do projeto. Além da bolsa-marido, que sem ela não terminaria esse último ano de doutorado!

Enfim, agradeço a todos que me ajudaram e contribuíram de alguma forma nesta caminhada. 

"We cannot all succeed when

half of us are held back."

Malala Yousafzai

Nobel da Paz - 2014 



\section{RESUMO}

FREDDI, P. Interações moleculares no mecanismo de ação de peptídeos de fusão e complexos metálicos de interesse farmacológico. 2018. 145 p. Tese (Doutorado em Ciências) - Faculdade de Filosofia, Ciências e Letras de Ribeirão Preto, Universidade de São Paulo, Ribeirão Preto, 2018.

O entendimento em nível molecular da interação tanto de vírus causadores de doenças (ou parte deles, como proteínas e peptídeos) quanto de moléculas candidatas a fármacos, é de suma importância para a terapia e tratamento de doenças. Neste trabalho, utilizamos técnicas biofísicas e bioquímicas para o estudo da interação entre miméticos de membrana e dois grupos de pequenas moléculas. A primeira relacionada a uma doença, o peptídeo de fusão da Dengue, sequência putativa da glicoproteína E do vírus da Dengue, e que se conserva entre outros flavivírus, como o vírus da Zika. Já o segundo grupo é formado por compostos de coordenação de cobre, Fenantrolina e os dipeptídeos Ala-Gly e Ala-Phe: Cu(L-dipeptídeo)(Fenantrolina), e que são potenciais candidatos a fármacos antitumorais. Nossos resultados mostram que as moléculas de ambos os grupos são capazes de interagir e modificar as propriedades do sistema mimético de membrana. Indicando que, por um lado, se pode pensar em estratégias de bloqueio da interação para evitar infecção pelo vírus e, por outro lado, se pode usar nossos resultados para melhor planejar formas de potencializar a interação em mecanismos de entrega de fármaco e/ou de difusão pela barreira física representada pelo sistema de membranas da célula tumoral.

Palavras-chave: Peptídeo de fusão da Dengue. Complexos metálicos. Cobre. Membranamodelo. Espectroscopia. 



\begin{abstract}
FREDDI, P. Molecular interactions in the action mechanism of fusion peptides and metal complexes of pharmacological interest. 2018. 145 p. Tese (Doutorado em Ciências) Faculdade de Filosofia, Ciências e Letras de Ribeirão Preto, Universidade de São Paulo, Ribeirão Preto, 2018.
\end{abstract}

The understanding at the molecular level of the interaction of both disease-causing viruses (or part thereof, such as proteins and peptides) and drug-candidate molecules is of paramount importance for the therapy and treatment of such diseases. In this work, we use biophysical techniques to study the interaction between membrane mimetics and two groups of small molecules. The first one is related to a disease, the Dengue fusion peptide, putative sequence of Dengue virus glycoprotein E, which is conserved among other flaviviruses, such as the Zika virus. The second group consists of coordination compounds of copper, Phenantroline and the dipeptides Ala-Gly and Ala-Phe: $\mathrm{Cu}$ (L-dipeptide) (phenanthroline), which are potential candidates for antitumor drugs. Our results show that the molecules form both groups are capable of interacting and modifying the physicchemical properties of the mimetic membrane system. This indicates that, on one hand, one can think in strategies of blocking the interaction to avoid virus infection and, on the other hand, one can use our results to improve membrane interaction in drug delivery mechanisms and/or for facilitating diffusion through the physical barrier represented by the membranes in tumor cells.

Keywords: Dengue fusion peptide. Metal complexes. Copper. Model-membrane. Spectroscopy. 



\section{LISTA DE FIGURAS}

Figura 1 - Modelo para a estrutura da membrana. (A) - Modelo de mosaico-fluido de Singer-Nicholson. (B) - Versão ATUALIZADA PARA O MODELO DA ESTRUTURA. FIGURA RETIRADA DE (3).

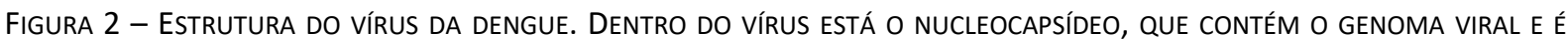
Cercado pelo envelope VIRAL, uma bicamada lipídica que É Retirada do hospedeiro. As proteínas E e M ATRAVESSAM A MEMBRANA E PROTEGEM A CAMADA EXTERNA QUE CONTROLA A ENTRADA DO VÍRUS EM CÉLULAS HUMANAS. FIGURA ADAPTADA DE (31). .31

Figura 3 - OS tRÊS dOMÍNIOS DA GLICOPROTEÍNA E do ENVELOPE VIRAL DO SOROTIPO 3 DA DENGUE. DOMÍNIO I EM VERMELHO, DOMínIo II EM AMARELO E dOMínIO III EM AZUL. A REGIÃo do PEPTídeO dE FUSÃo ESTÁ DESTACADA COM AS SETAS EM VERDE. FIGURA ADAPTADA DE (35).

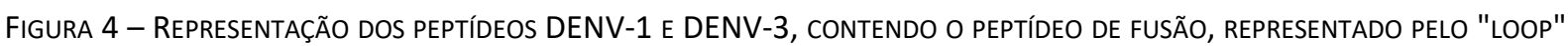
QUE ESTÁ INDICADO PELA SETA NA FIGURA APRESENTAdA. DESTACAdO EM VERMELHO ESTÃo REPRESENTADAS AS LIGAÇÕES DISSULFETO QUE ESTABILIZAM AS REGIÕES FLANQUEAdORAS AO PEPTídeO DE FUSÃo. FiguRA ELABORADA PELA AUTORA E

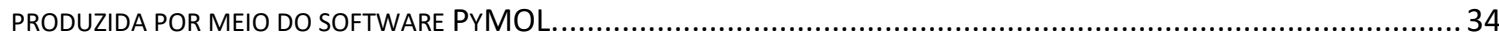

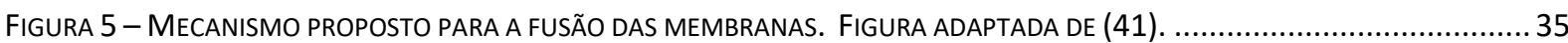

FIGURA 6 - ESTRUTURAS QUÍMICAS DE TODOS OS FOSFOLIPÍDIOS E SONDAS FLUORESCENTES E DOIS EXEMPLOS DOS MARCADORES PARAMAGNÉTICOS N-PCSL UTILIZADOS NESTE TRABALHO. FIGURA ADAPTADA DE (72).

FiguRA 7 - SEQUÊNCIAS PRIMÁRIAS NATIVAS dOS PEPTídeOS DENV-1 (88-123) E DEN-3 (88-123) CONTENDO O PEPTídeO DE FusÃo (98-113) E SUAS REgIÕES FLANQUEAdORAS. NOTA-SE QUE AS CISTEínAS (DESTACAdAS EM AZUL) SITUAM-SE NA MESMA POSIÇÃO, EM AMBAS AS SEQUÊNCIAS dOS SOROTIPOS 1 E 3: 92, 105, 116 E 121. FIGURA ELABORAdA PELA AUTORA.

FiguRA 8 - Esquema do COMPLEXo de COORDENAÇÃo [Cu(DIPEPTídeO)(PHEN)]. ONDE R2 $=$ H PARA L-ALA-GLY E R ${ }_{2}=\mathrm{CH}_{2}-\mathrm{PHENYL}$ PARA L-Ala-PHE. FiguRA ADAPTADA DE (66)

FIGURA 9 - ESPECTRO DE CD ASSOCIADO A REGIÃO UV DISTANTE COM OS DIVERSOS TIPOS DE ESTRUTURAS SECUNDÁRIAS. LINHA SÓlIDA, A-HÉliCE; LINHA TRACEJADO LONGO, FOLHA-B ANTI-PARALELA; LINHA PONTILHADA, VOLTA-B TIPO I; LINHA PONTILHADA CRUZADA, 3-1-HÉLICE ESTENDIDA OU POLI (PRO) II HÉLICE; LINHA PONTILHADO CURTO, ESTRUTURA IRREGULAR. FIGURA ADAPTADA DE (78).

FIGURA 10 - REPRESENTAÇÃO DE UM ENSAIO DE MISTURA LIPÍDICA BASEADO EM FRET. COM OS FLUORÓFOROS NA MESMA VESÍCULA, OCORRE A TRANSFERÊNCIA DE ENERGIA DO NBD-PE (DOADOR) PARA O RH-PE (RECEPTOR); COM A FUSÃO DAS VESÍCULAS, A DISTÂNCIA ENTRE AS SONDAS AUMENTA, O QUE RESULTA EM UM FRET MENOR, COM O AUMENTO NA FLUORESCÊNCIA DO NBD-PE. FIGURA ADAPTADA DE (83).

Figura 11 - Esquema Representativo de um termograma. A difERENÇA NA CAPACIDAde CALORíFICA, $\Delta$ Cp, DO EVENTO TÉRMICO É CARACTERIZADA PELA TEMPERATURA DE TRANSIÇÃO DE FASE TM, ONDE A CAPACIDADE CALORIFICA ATINGE UM

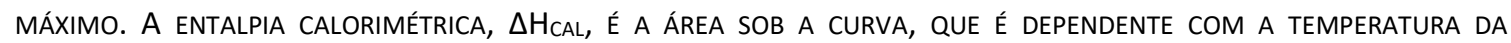
CAPACIDADE CALORÍFICA DA AMOSTRA À PRESSÃO CONSTANTE. FIGURA ELABORADA PELA AUTORA. 
FIgURA 12 - DEFINIÇões dOS PARÂMETROS EMPÍRICOS UTILIZAdOS PARA A ANÁLISE DOS ESPECTROS DE RPE PARA O RADICAL NITRÓXIDO EM MEMBRANAS, NO REGIME (A) MAIS RÁPIDO E (B) MAIS LENTO. FIGURA ELABORADA PELA AUTORA. 58

FIGURA 13 - REAÇÃO dA LIGAÇÃO dO MARCADOR DE SPIN MTSSL ÀS CADEIAS LATERAIS DA CISTEÍNA. FIGURA ADAPTADA DE (97). 59

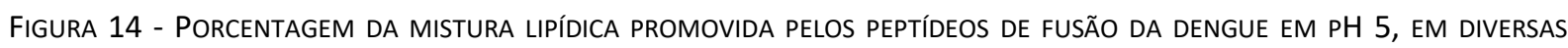
RAZÕES MOLARES LIPÍDIO/PEPTídeO $(45,100,150,200)$. AS RAZÕES MÁXIMA E MÍNIMA FORAM ESCOLHIDAS POIS SÃO AS RAZÕES L/P CRÍTICAS, ONDE ABAIXO DISSO NÃO HÁ MISTURA LIPÍDICA DETECTADA E ACIMA DA RAZÃO MÁXIMA HÁ UMA MAIOR AGREGAÇÃO DOS PEPTÍDEOS, IMPOSSIBILITANDO DIFERENCIAR ESTE EVENTO DA MISTURA LIPÍDICA. FIGURA ELABORADA PELA AUTORA.

FiguRA 15 - PORCENTAGEM dA MISTURA LIPÍDICA PROMOVIDA PELOS PEPTídEOS DE FUSÃo DA DENGUE EM PH 7,4, NAS RAZÕES MOLARES L/P 45 E 100. NÃO CONSEGUIMOS DETECTAR MISTURA LIPÍDICA COM CONCENTRAÇÕES MENORES DE PEPTíDEO. FIGURA ELABORADA PELA AUTORA. .65

FigURA 16 - DistribuIÇÃo do VolUME (RELATIVO\%) DE LUVS DE POPC/POPG, NA AUSÊNCIA E NA PRESENÇA DOS PEPTídEOS DE FusÃo dos SOROTIPOS 1 e 3 dA DENGUE. FIgURA ELABORAdA PELA AUTORA. 68

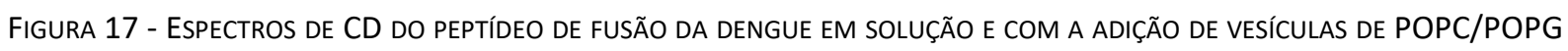
NOS PHS 5 E 7,4. FIGURA ELABORADA PELA AUTORA.

FiguRA 18 - ESPECTROS DE CD dO PEPTÍdEO dE FUSÃO E SUAS REGIÕES FLANQUEADORAS DOS SOROTIPOS 1 E 3 DA DENGUE, EM SOLUÇÃO E COM A ADIÇÃO DE VESÍCULAS DE POPC/POPG NOS PHS 5 E 7,4. FIGURA ELABORADA PELA AUTORA. 70

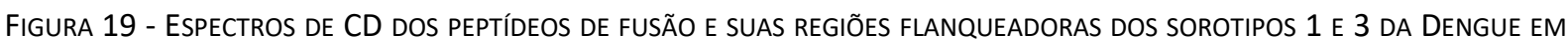
SOLUÇÃO TAMPÃO FOSFATO PH 7,4 E COM DIFERENTES CONCENTRAÇÕES DE TFE. FIGURA ELABORADA PELA AUTORA..........71

Figura 20 - ESPECTROS de EMISSÃo do TRP dos PEPtídeOS DENV-1 E 3 NA AUSÊNCIA E NA PRESENÇA DE DIVERSAS CONCENTRAÇÕES DE LUVS DE POPC/POPG EM PH 5. FIGURA ELABORADA PELA AUTORA. 73

FIGURA 21 - DETERMINAÇÃO DA CONSTANTE DE PARTIÇÃO, Kp, DOS PEPTíDEOS EM ESTUDO, ATRAVÉS DA MUDANÇA DA INTENSIDADE DE FLUORESCÊNCIA DO TRP NA PRESENÇA DAS VESÍ́CULAS EM PH 5. FIGURA ELABORADA PELA AUTORA.

FIGURA 22 - EsPeCtRos de EMISSÃo dOS PEPTídeOS PFDEN NA AUSÊNCIA (LINHA PRETA) E NA PRESENÇA (LINHA VERMELHA) DAS VESÍ́CULAS DE POPC/POPG, NOS PHS 5 (LINHA SÓLIDA) E 7,4 (LINHA TRACEJADA). FIGURA ELABORADA PELA AUTORA........75

FIGURA 23 - ESPECTROS DE EMISSÃO DOS PEPTídEOS DENV-1, NA AUSÊNCIA E NA PRESENÇA DAS VESÍCULAS DE POPC/POPG, NOS PHS 5 (LINHA SÓLIDA) E 7,4 (LINHA TRACEJADA). FIGURA ELABORADA PELA AUTORA. 76

FiguRA 24 - ESPECTROS dE EMISSÃo dOS PEPTídeOS DENV-3, NA AUSÊNCIA E NA PRESENÇA DAS VESíCULAS DE POPC/POPG, NOS PHS 5 (LINHA SÓLIDA) E 7,4 (LINHA TRACEJADA). FIGURA ELABORADA PELA AUTORA. 76

FIGURA 25 - GRÁFICO DE STERN-VOLMER DA SUPRESSÃO DE FLUORESCÊNCIA PELA ACRILAMIDA DO PEPTídEO DE FUSÃo DA DENGUE EM SOLUÇão AQUOSA E NA PRESENÇA DE VESÍCULAS DE POPC/POPG (4/1) NOS PHS 5 E 7,4. FIGURA ELABORADA PELA AUTORA.

Figura 26 - GRÁfICO de SteRn-Volmer dA SUPRESSÃo dE FLUORESCÊNCIA PELA ACRILAMIDA dOS PEPTídEOS DE FUSÃO DO SOROTIPO 1 e 3 dA DENGUE EM SOLUÇÃo AQUOSA E NA PRESENÇA DE VESíCULAS DE POPC/POPG (4/1) NO PH 5. FIGURA ELABORADA PELA AUTORA.

Figura 27 - GRÁFICO de SteRn-Volmer dA SUPRESSÃO DE FLUORESCÊNCIA PELA ACRILAMIDA dOS PEPTídEOS DE FUSÃO DO SOROTIPO 1 E 3 dA DENGUE EM SOLUÇão AQUOSA E NA PRESENÇA DE VESÍCULAS DE POPC/POPG (4/1) NO PH 7,4. FIGURA ELABORADA PELA AUTORA. 
Figura 28 - Espectros de RPE PARA os MARCADORES 5, 7, 10, 12, 14 e 16-PCSL E DOPTC eM Vesículas COMPOSTAS POR POPC/POPG, ANTES E APÓS A ADIÇÃO DOS PEPTÍDEOS, EM PH 5. FIGURA ELABORADA PELA AUTORA..............................81

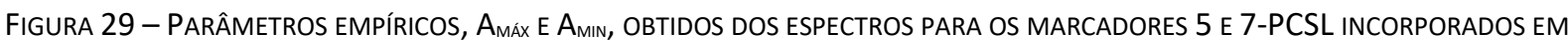
VESÍCULAS DE POPC/POPG, NA AUSÊNCIA E NA PRESENÇA DOS PEPTÍDEOS EM PH 5. FIGURA ELABORADA PELA AUTORA..... 82 FiguRA 30 - PARÂMETROS H-1/Ho E H+1/Ho PARA OS MARCADORES 10, 12, 14 E 16-PCSL E DOPTC INCORPORADOS EM VESí́CULAS DE POPC/POPG, NA AUSÊNCIA E NA PRESENÇA DOS PEPTÍDEOS EM PH 5. FIGURA ELABORADA PELA AUTORA. .83

Figura 31 - Espectros de EPR dos ANÁlogos dos peptídeos de fusão de fusão PFDEN maRCAdos PELA SONDA PARAMAGNÉTICA MTSSL, NA AUSÊNCIA E NA PRESENÇA DE VESíCULAS DE POPC:POPG NA RAZÃo MOLAR L/P DE 45 EM PH 5. FIGURA ELABORADA PELA AUTORA.

FIGURA 32 - TERMOGRAMA DE DSC ILUSTRANDO OS EFEITOS DOS PEPTÍDEOS NO COMPORTAMENTO TERMOTRÓPICO DA BICAMADA LIPÍDICA DE DPPC/DPPG EM PH 5. FIGURA ELABORADA PELA AUTORA. 86

Figura 33 - TeRmograma de DSC ILUSTRANDO os EFEITOS dOS PEPTídeOS NO COMPORTAMENTO TERMOTRÓPICO DA PRÉTRANSIÇÃO (INSET) E TRANSIÇÃO PRINCIPAL DA BICAMADA LIPÍDICA DE DPPC/DPPG EM PH 7,4. FIGURA ELABORADA PELA AUTORA.

Figura 34 - Perfil de Densidade eletrônica para os peptídeos em interação com a bicamada lipídica. Parte superior: DECOMPOSIÇÃO DOS LIPÍDIOS, ÁGUA E POSICIONAMENTO DO ÁTOMO DE FÓSFORO; PARTE INFERIOR: POSICIONAMENTO DOS PEPTídEOS. FIGURA ELABORADA POR DANILO OLIVIER.

FIGURA 35 - VARIAÇÃo TEMPORAL dA ÁREA MÉDIA POR CABEÇA LIPÍDICA PARA BICAMADA DE POPC/POPG NA PRESENÇA DE PEPTÍDEOS. FIGURA ELABORADA POR DANILO OLIVIER

Figura 36 - PARÂMETRO de ORdeM PARA A BICAMAdA LIPÍdICA DE POPC/POPG NA AUSÊNCIA E NA PRESENÇA DOS PEPTídEOS. PARÂMETRO DE ORDEM PARA AS CADEIAS SN-1 E SN-2 E ESQUEMA REPRESENTATIVO DAS CADEIAS SN-1 E SN-2 PARA O LIPÍDIO DE POPC. FIGURA ELABORADA POR DANILO OLIVIER.

Figura 37 - MAPA dA EVOLUÇão temporal dA ESTRUTURA SECUNDÁRIA PARA OS PEPTídeOS VIRAIS. FiguRA ELABORADA POR DANILO OLIVIER. 95

FIGURA 38 - INSERÇÃO do RESÍdUO TRIPTOFANO (W101) NA BICAMADA LIPÍDICA AO LONGO DA SIMULAÇÃO. FIGURA ELABORADA POR DANILO OLIVIER.

Figura 39 - IMAgenS REPRESENTATIVAS dOS SISTEMAS AO LONGO dA SIMULAÇÃO. A - PFDEN, B - DENV-1C, C -DENV-1S, D DENV-3C, E - DENV-3S. FIGURA ELABORADA POR DANILO OLIVIER.

FIgURA 40 - TERMOGRAMAS DE DSC DAS MLVS DE DPPC NA AUSÊNCIA E NA PRESENÇA DOS COMPOSTOS. FIGURA ELABORADA PELA AUTORA. 99

FIGURA 41 - TERMOGRAMA dAS MLVS DE DPPG NA AUSÊNCIA E NA PRESENÇA DOS COMPOSTOS. FIGURA ELABORADA PELA AUTORA.

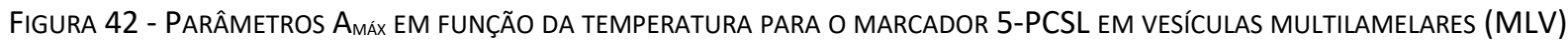
DE DPPC E DPPG, NA AUSÊNCIA E NA PRESENÇA DOS COMPOSTOS. FIGURA ELABORADA PELA AUTORA. 104

Figura 43 - PARÂMETROS H+1/Ho EM FUNÇÃO DA TEMPERATURA PARA O MARCADOR 16-PCSL EM MLVS DE DPPC E DPPG, NA AUSÊNCIA E NA PRESENÇA DOS COMPOSTOS, ONDE O INSET MOSTRA OS PARÂMETROS NORMALIZADOS. FIGURA ELABORADA PELA AUTORA. 
Figura 44 - PARÂMETROS H+1/Ho EM FUnÇÃo dA TEMPERATURA PARA O MARCADOR DOPTC EM MLVS DE DPPC E DPPG, NA AUSÊNCIA E NA PRESENÇA DOS COMPOSTOS, ONDE O INSET MOSTRA OS PARÂMETROS NORMALIZADOS. FIGURA ELABORADA PELA AUTORA.

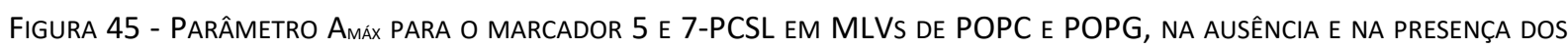
COMPOSTOS. AS MEDIDAS FORAM REALIZADAS A $25^{\circ} \mathrm{C}$, ONDE OS DOIS MIMÉTICOS DE MEMBRANA ESTÃO NA FASE FLUIDA. FIGURA ELABORADA PELA AUTORA. 106

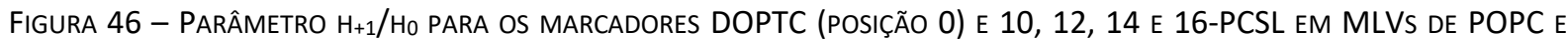
POPG, NA AUSÊNCIA E NA PRESENÇA DOS COMPOSTOS. AS MEDIDAS FORAM REALIZADAS A $25^{\circ} \mathrm{C}$, ONDE OS DOIS MIMÉTICOS DE MEMBRANA ESTÃO NA FASE FLUIDA. FIGURA ELABORADA PELA AUTORA. 106

FIGURA 47 - ESPECTROS DE RPE EM FUNÇÃO DA TEMPERATURA DAS MODELOS DE MEMBRANA CONTENDO DPPC E A SONDA 5PCSL. FIGURA ELABORADA PELA AUTORA. 129

FIGURA 48 - ESPECTROS DE RPE EM FUNÇÃO DA TEMPERATURA DAS MODELOS DE MEMBRANA CONTENDO DPPC E A SONDA 5-PCSL NA PRESENÇA DO LIGANTE PHEN. FIGURA ELABORADA PELA AUTORA. 130

FIGURA 49 - ESPECTROS DE RPE EM FUNÇÃO DA TEMPERATURA DAS MODELOS DE MEMBRANA CONTENDO DPPC E A SONDA 5-PCSL NA PRESENÇA DO COMPLEXO CU(PHEN). FIGURA ELABORADA PELA AUTORA. 130

FIGURA 50 - ESPECTROS DE RPE EM FUNÇÃO DA TEMPERATURA DAS MODELOS DE MEMBRANA CONTENDO DPPC E A SONDA 5-PCSL NA PRESENÇA DO COMPLEXO Cu(AG)(PHEN). FIGURA ELABORADA PELA AUTORA. 131

FIGURA 51 - ESPECTROS DE RPE EM FUNÇÃO DA TEMPERATURA DAS MODELOS DE MEMBRANA CONTENDO DPPC E A SONDA 5-PCSL NA PRESENÇA DO COMPLEXO CU(AP)(PHEN). FIGURA ELABORADA PELA AUTORA.

FIGURA 52 - ESPECTROS DE RPE EM FUNÇÃO DA TEMPERATURA DAS MODELOS DE MEMBRANA CONTENDO DPPC E A SONDA 16PCSL. FIGURA ELABORADA PELA AUTORA. 132

FiguRA 53 - ESPECTROS DE RPE EM FUNÇÃO DA TEMPERATURA DAS MODELOS DE MEMBRANA CONTENDO DPPC E A SONDA 16PCSL NA PRESENÇA DA MOLÉCULA PHEN. FIGURA ELABORADA PELA AUTORA. 132

FIGURA 54 - ESPECTROS DE RPE EM FUNÇÃO DA TEMPERATURA DAS MODELOS DE MEMBRANA CONTENDO DPPC E A SONDA 16PCSL NA PRESENÇA DO COMPLEXO CU(PHEN). FIGURA ELABORADA PELA AUTORA...... 133

FIGURA 55 - ESPECTROS DE RPE EM FUNÇÃO DA TEMPERATURA DAS MODELOS DE MEMBRANA CONTENDO DPPC E A SONDA 16PCSL NA PRESENÇA DO COMPLEXO CU(AG)(PHEN). FIGURA ELABORADA PELA AUTORA. 133

FiguRA 56 - ESPECTROS DE RPE EM FUNÇÃO DA TEMPERATURA DAS MODELOS DE MEMBRANA CONTENDO DPPC E A SONDA 16PCSL NA PRESENÇA DO COMPLEXO CU(AP)(PHEN). FIGURA ELABORADA PELA AUTORA. 134

FIGURA 57 - ESPECTROS DE RPE EM FUNÇÃO DA TEMPERATURA DAS MODELOS DE MEMBRANA CONTENDO DPPC E A SONDA DOPTC. FIGURA ELABORADA PELA AUTORA. 134

FiguRA 58 - ESPECTROS DE RPE EM FUNÇÃO DA TEMPERATURA DAS MODELOS DE MEMBRANA CONTENDO DPPC E A SONDA DOPTC, NA PRESENÇA DA MOLÉCULA DE PHEN. FIGURA ELABORADA PELA AUTORA. 135

FiguRA 59 - ESPECTROS DE RPE EM FUNÇÃO DA TEMPERATURA DAS MODELOS DE MEMBRANA CONTENDO DPPC E A SONDA DOPTC, NA PRESENÇA DO COMPLEXO CU(PHEN). FIGURA ELABORADA PELA AUTORA.

FiguRA 60 - EsPECTROS DE RPE EM FUnÇÃo dA TEMPERATURA DAS MODELOS DE MEMBRANA CONTENDO DPPC E A SONDA DOPTC, NA PRESENÇA DO COMPLEXO CU(AG)(PHEN). FIGURA ELABORADA PELA AUTORA. 136 
FiguRA 61 - ESPECTROS DE RPE EM FUnÇÃo DA TEMPERATURA DAS MODELOS DE MEMBRANA CONTENDO DPPC E A SONDA DOPTC, NA PRESENÇA DO COMPLEXO CU(AP)(PHEN). FIGURA ELABORADA PELA AUTORA. 136

FIGURA 62 - ESPECTROS DE RPE EM FUNÇÃO DA TEMPERATURA DAS MOdELOS DE MEMBRANA CONTENDO DPPG E A SONDA 5-

PCSL. FIGURA ELABORADA PELA AUTORA.

FIGURA 63 - ESPECTROS DE RPE EM FUNÇÃO DA TEMPERATURA DAS MODELOS DE MEMBRANA CONTENDO DPPG E A SONDA 5-PCSL NA PRESENÇA DA MOLÉCULA PHEN. FIGURA ELABORADA PELA AUTORA.

FIGURA 64 - ESPECTROS DE RPE EM FUNÇÃO DA TEMPERATURA DAS MODELOS DE MEMBRANA CONTENDO DPPG E A SONDA 5-PCSL NA PRESENÇA DO COMPLEXO CU(PHEN). FIGURA ELABORADA PELA AUTORA.

FIGURA 65 - ESPECTROS DE RPE EM FUNÇÃO DA TEMPERATURA DAS MODELOS DE MEMBRANA CONTENDO DPPG E A SONDA 5PCSL NA PRESENÇA DO COMPLEXO CU(AG)(PHEN). FIGURA ELABORADA PELA AUTORA. 138

FigURA 66 - ESPECTROS DE RPE EM FUnÇÃO DA TEMPERATURA DAS MODELOS DE MEMBRANA CONTENDO DPPG E A SONDA 5PCSL NA PRESENÇA DO COMPLEXO Cu(AP)(PHEN). FIGURA ELABORADA PELA AUTORA. 139

FIGURA 67 - ESPECTROS DE RPE EM FUNÇÃO DA TEMPERATURA DAS MODELOS DE MEMBRANA CONTENDO DPPG E A SONDA 16PCSL. FIGURA ELABORADA PELA AUTORA. 139

FIGURA 68 - ESPECTROS DE RPE EM FUNÇÃO DA TEMPERATURA DAS MODELOS DE MEMBRANA CONTENDO DPPG E A SONDA 16PCSL NA PRESENÇA DO LIGANTE PHEN. FIGURA ELABORADA PELA AUTORA. 140

FIGURA 69 - ESPECTROS DE RPE EM FUNÇÃO DA TEMPERATURA DAS MODELOS DE MEMBRANA CONTENDO DPPG E A SONDA 16PCSL NA PRESENÇA DO COMPLEXO CU(PHEN). FIGURA ELABORADA PELA AUTORA.. 140

FIGURA 70 - ESPECTROS DE RPE EM FUNÇÃO DA TEMPERATURA DAS MODELOS DE MEMBRANA CONTENDO DPPG E A SONDA 16PCSL NA PRESENÇA DO COMPLEXo Cu(AG)(PHEN). FiguRA ELABORADA PELA AUTORA. 141

FIGURA 71 - ESPECTROS DE RPE EM FUNÇÃO DA TEMPERATURA DAS MODELOS DE MEMBRANA CONTENDO DPPG E A SONDA 16PCSL NA PRESENÇA DO COMPLEXO CU(AP)(PHEN). FIGURA ELABORADA PELA AUTORA. 141

FiguRA 72 - ESPECTROS DE RPE EM FUNÇÃO DA TEMPERATURA DAS MODELOS DE MEMBRANA CONTENDO DPPG E A SONDA DOPTC. FIGURA ELABORADA PELA AUTORA. 142

FIGURA 73 - ESPECTROS DE RPE EM FUNÇÃO DA TEMPERATURA DAS MODELOS DE MEMBRANA CONTENDO DPPG E A SONDA DOPTC NA PRESENÇA DA MOLÉCULA PHEN. FIGURA ELABORADA PELA AUTORA.

FIGURA 74 - ESPECTROS DE RPE EM FUNÇÃO DA TEMPERATURA DAS MODELOS DE MEMBRANA CONTENDO DPPG E A SONDA DOPTC NA PRESENÇA DO COMPLEXO CU(PHEN). FIGURA ELABORADA PELA AUTORA.

FIGURA 75 - ESPECTROS DE RPE EM FUNÇÃO DA TEMPERATURA DAS MODELOS DE MEMBRANA CONTENDO DPPG E A SONDA DOPTC NA PRESENÇA DO COMPLEXO Cu(AG)(PHEN). FIGURA ELABORADA PELA AUTORA.

FIGURA 76 - ESPECTROS DE RPE EM FUNÇÃO DA TEMPERATURA DAS MODELOS DE MEMBRANA CONTENDO DPPG E A SONDA DOPTC NA PRESENÇA DO COMPLEXO CU(AP)(PHEN). FIGURA ELABORADA PELA AUTORA.

FIGURA 77 - ESPECTROS DE RPE dO MODELO DE MEMBRANA CONTENDO POPC E A SONDA DOPTC NA AUSÊNCIA E NA PRESENÇA DAS MOlÉCULAS DE ESTUdo. FiguRA ELABORADA PELA AUTORA. 145

FIGURA 78 - ESPECTROS DE RPE dO MOdELO DE MEMBRANA CONTENDO POPC E A SONDA 5-PCSL NA AUSÊNCIA E NA PRESENÇA DAS MOLÉCULAS DE ESTUdO. FIgURA ELABORAdA PELA AUTORA.

FiguRA 79 - ESPECTROS DE RPE DO MODELO DE MEMBRANA CONTENDO POPC E A SONDA 7-PCSL NA AUSÊNCIA E NA PRESENÇA DAS MOLÉCULAS DE ESTUDO. FIGURA ELABORADA PELA AUTORA. 
FiguRA 80 - EsPeCtros de RPE do MODELO dE MEMBRANA CONTENDO POPC E A SONDA 10-PCSL NA AUSÊNCIA E NA PRESENÇA

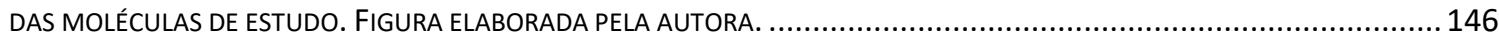

FIGURA 81 - ESPECTROS DE RPE dO MODELO DE MEMBRANA CONTENDO POPC E A SONDA 12-PCSL NA AUSÊNCIA E NA PRESENÇA DAS MOLÉCULAS DE ESTUdO. FIGURA ELABORADA PELA AUTORA

FigURA 82 - ESPECTROS DE RPE dO MODELO DE MEMBRANA CONTENDO POPC E A SONDA 14-PCSL NA AUSÊNCIA E NA PRESENÇA DAS MOLÉCULAS DE ESTUdO. FIGURA ELABORADA PELA AUTORA.

FIGURA 83 - ESPECTROS DE RPE dO MODELO DE MEMBRANA CONTENDO POPC E A SONDA 16-PCSL NA AUSÊNCIA E NA PRESENÇA DAS MOLÉCULAS DE ESTUDO. FIGURA ELABORADA PELA AUTORA.

FiguRA 84 - ESPECTROS DE RPE DO MODELO DE MEMBRANA CONTENDO POPG E A SONDA DOPTC NA AUSÊNCIA E NA PRESENÇA DAS MOLÉCULAS DE ESTUDO. FIGURA ELABORADA PELA AUTORA. 148

FiguRA 85 - ESPECTROS DE RPE dO MODELO DE MEMBRANA CONTENDO POPG E A SONDA 5-PCSL NA AUSÊNCIA E NA PRESENÇA DAS MOLÉCULAS DE ESTUdO. FIGURA ELABORADA PELA AUTORA.

FIGURA 86 - ESPECTROS DE RPE dO MODELO DE MEMBRANA CONTENDO POPG E A SONDA 7-PCSL NA AUSÊNCIA E NA PRESENÇA DAS MOLÉCULAS DE ESTUdO. FIGURA ELABORADA PELA AUTORA. 149

FiguRA 87 - ESPECTROS DE RPE DO MODELO DE MEMBRANA CONTENDO POPG E A SONDA 10-PCSL NA AUSÊNCIA E NA PRESENÇA DAS MOLÉCULAS DE ESTUDO. FIGURA ELABORADA PELA AUTORA. 149

FIGURA 88 - ESPECTROS DE RPE DO MODELO DE MEMBRANA CONTENDO POPG E A SONDA 12-PCSL NA AUSÊNCIA E NA PRESENÇA DAS MOLÉCULAS DE ESTUDO. FIGURA ELABORADA PELA AUTORA. 149

FigURA 89 - ESPECTROS DE RPE DO MODELO DE MEMBRANA CONTENDO POPG E A SONDA 14-PCSL NA AUSÊNCIA E NA PRESENÇA DAS MOLÉCULAS DE ESTUdO. FIGURA ELABORADA PELA AUTORA. 150

FIGURA 90-ESPECTROS DE RPE DO MODELO DE MEMBRANA CONTENDO POPG E A SONDA 16-PCSL NA AUSÊNCIA E NA PRESENÇA DAS MOLÉCULAS DE ESTUDO. FIGURA ELABORADA PELA AUTORA. 150 


\section{LISTA DE TABELAS}

TABela 1 - SequÊnClas nativas de peptídeos de fusão de alguns flaVivírus, tRanSmitidos por difERENTES Vetores (MOSQUITOS E CARRAPATOS). OS AMINOÁCIDOS EM NEGRITO SÃO AS MUDANÇAS QUE OCORREM DE UMA SEQUÊNCIA PARA OUTRA. TABELA ADAPTADA DE (33).

TABELA 2 - FOSFOLIPÍDIOS, SONDAS FLUORESCENTES E PARAMAGNÉTICAS, UTILIZADAS NESTE TRABALHO, ADQUIRIDOS COMERCIALMENTE. TABELA ELABORADA PELA AUTORA.

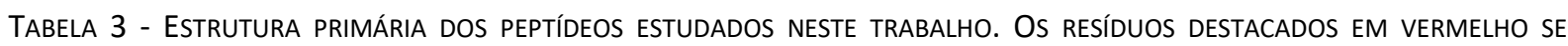
REFEREM ÀS SUBSTITUIÇÕES CISTEÍNA-SERINA QUE FORAM REALIZADAS PARA A CONVENIÊNCIA DA SÍNTESE E/OU DO ESTUDO. TABELA ELABORADA PELA AUTORA.

TABELA 4 - COMPOSTOS METÁLICOS ESTUDADOS NESTE TRABALHO. TABELA ELABORADA PELA AUTORA..... .47

TABELA 5 - COMPOSIÇÃO DOS SISTEMAS SIMULADOS. TABELA ELABORADA PELA AUTORA.

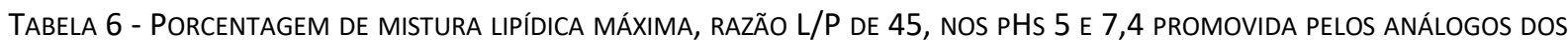
PEPTídEOS DE FUSÃo DA DENGUE SOROTIPOS $1 \mathrm{E}$ 3. TABELA ELABORADA PELA AUTORA. 66

TABELA 7 - CARGA dOS PEPTídeOS EM ESTUdO NOS PHS 5 E 7,4, ONDE AS CORES DIFERENTES DOS RESÍDUOS INDICAM: VERMELHO RESÍDUOS ÁCIDOS, AZUL - RESÍDUOS BÁSICOS E LARANJA - RESÍDUOS NÃO CARREGADOS HIDROFÓBICOS. DADOS OBTIDOS

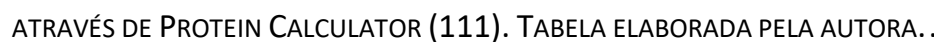

TABELA 8 - DistribuIÇÃo do tAMANHO DAS VESíCULAS EXPRESSO COMO O RAIO HIDRODINÂMICO (NM), OBTIDOS NOS EXPERIMENTOS DE DLS, COMPOSTAS POR POPC/POPG, PURAS E COM A ADIÇÃO DOS PEPTídEOS DENV-1 e 3 EM PH 5. TABELA ELABORADA PELA AUTORA.

TABela 9 - Constante de partição e fração molar dos Peptídeos DENV-1 e 3 ligados À membrana, em PH 5. TABela ELABORADA PELA AUTORA.

TABela 10 - Valores de Ksv para os peptídeos em miméticos de membrana e em Solução aquosa em pH 5. TABela ELABORADA PELA AUTORA.

Tabela 11 - Valores de Ksv para os peptídeos em miméticos de membrana e em Solução aquosa em pH 7,4. TABela ELABORADA PELA AUTORA.

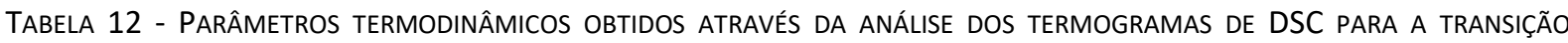
PRINCIPAL DO FOSFOLIPÍDIO DPPC, NA PRESENÇA E NA AUSÊNCIA DOS COMPOSTOS. TABELA ELABORADA PELA AUTORA..... 100

TABELA 13 - PARÂMETROS TERMOdINÂMICOS ObTIDOS ATRAVÉS DA ANÁlISE DOS TERMOGRAMAS DE DSC DA PRÉ-TRANSIÇÃO DO FOSFOLIPÍDIO DPPC, NA PRESENÇA E NA AUSÊNCIA DOS COMPOSTOS. TABELA ELABORADA PELA AUTORA. 101

TABELA 14 - PARÂMETROS TERMODINÂMICOS OBTIDOS ATRAVÉS DA ANÁLISE DOS TERMOGRAMAS DE DSC DA TRANSIÇÃO PRINCIPAL DO FOSFOLIPÍDIO DPPG NA PRESENÇA E NA AUSÊNCIA DOS COMPOSTOS. TABELA ELABORADA PELA AUTORA. 103 



\section{LISTA DE ABREVIATURAS E SIGLAS}

PFDEN Peptídeo de fusão da Dengue

DENV-nC Peptídeo de fusão da dengue e suas regiões flanqueadoras dos sorotipos 1 ou 3 contendo as cisteínas que formam a ponte dissulfeto $(n=1$ ou3)

DENV-nS Peptídeo de fusão da dengue e suas regiões flanqueadoras dos sorotipos 1 ou 3 com as cisteínas mutadas por serina $(n=1$ ou3 $)$

$\mathrm{Cu} \quad$ Cobre

phen Fenantrolina

Cu-phen Complexo de coordenação contendo cobre e Fenantrolina

RPE Ressonância Paramagnética Eletrônica

DSC Calorimetria Diferencial de Varredura (do inglês, Differential Scanning Calorimetry)

n-PCSL 1-Palmitoil-2-(n-doxil estearoil) Fosfatidilcolina $(n=5,12$ e 16)

$\mathbf{T}_{\mathbf{M}} \quad$ Temperatura de transição de fase principal ou temperatura de melting

Tp Temperatura da pré-transição

$\Delta \mathbf{H} \quad$ Entalpia calorimétrica da transição de fase principal

$\Delta \mathrm{T}_{\mathbf{1} 2 \mathbf{2}} \quad$ Largura da transição principal à meia altura

A $\quad$ Déx $\quad$ Desdobramento hiperfino máximo

$\mathbf{h}_{+1} / \mathbf{h}_{0} \quad$ Razão entre as amplitudes das linhas de campo baixo e central

$\mathbf{h}_{-1} / \mathbf{h}_{\mathbf{0}} \quad$ Razão entre as amplitudes das linhas de campo alto e central 
Vesícula unilamelar grande

MLV

Vesícula multilamelar grande

L/P Razão molar lipídio/peptídeo 


\section{LISTA DE AMINOÁCIDOS}

\begin{tabular}{|c|c|c|}
\hline Aminoácido & Sigla de uma letra & Sigla de três letras \\
\hline Alanina & $A$ & Ala \\
\hline Arginina & $\mathrm{R}$ & Arg \\
\hline Asparagina & $\mathrm{N}$ & Asn \\
\hline Aspartato ou ácido aspártico & $\mathrm{D}$ & Asp \\
\hline Cisteína & C & Cys \\
\hline Fenilalanina & $\mathrm{F}$ & Phe \\
\hline Glicina & G & Gly \\
\hline Glutamato ou Ácido glutâmico & $\mathrm{E}$ & Glu \\
\hline Glutamina & Q & Gln \\
\hline Histidina & $\mathrm{H}$ & His \\
\hline Isoleucina & 1 & Ile \\
\hline Leucina & $\mathrm{L}$ & Leu \\
\hline Lisina & K & Lys \\
\hline Serina & $S$ & Ser \\
\hline Tirosina & Y & Tyr \\
\hline Treonina & $\mathrm{T}$ & Thr \\
\hline Triptofano & W & Trp \\
\hline Valina & V & Val \\
\hline
\end{tabular}





\section{SUMÁRIO}

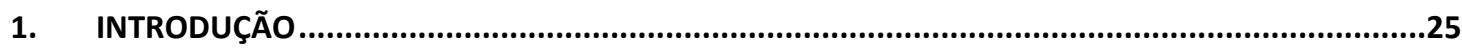

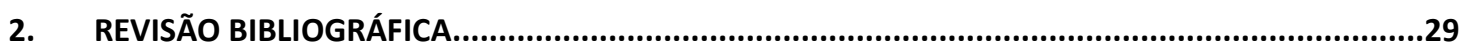

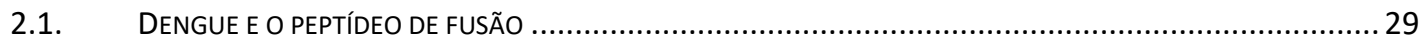

2.2. COMPOSTOS DE COORDENAÇÃO: COBRE, FENANTROLINA E DIPEPTÍDEOS........................................ 35

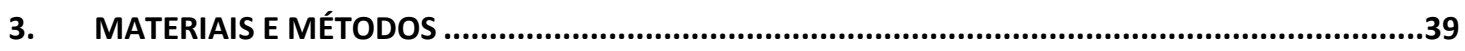

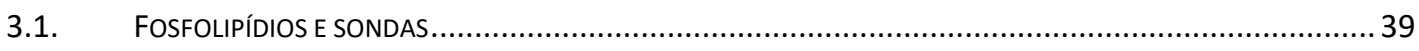

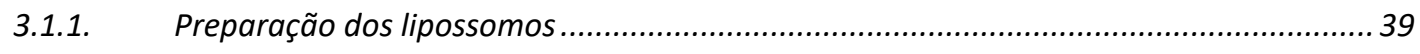

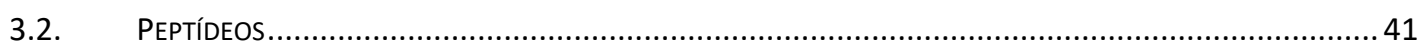

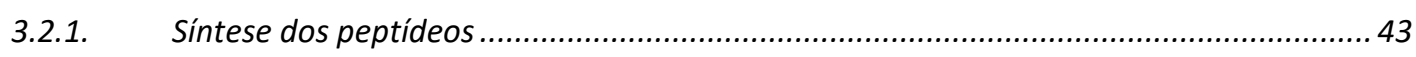

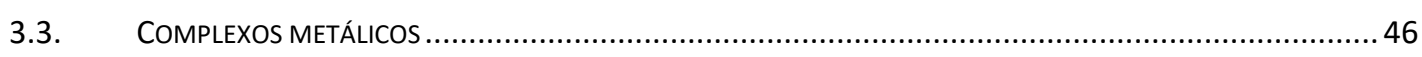

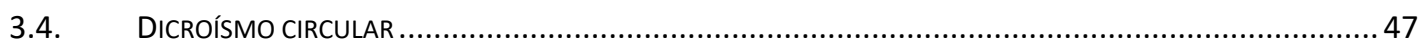

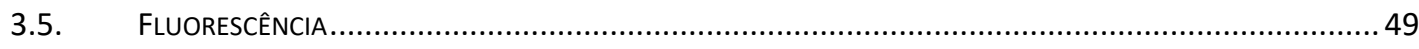

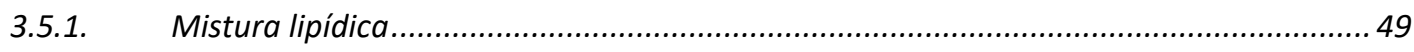

3.5.2. Fluorescência do Triptofano ......................................................................... 51

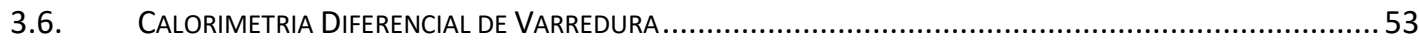

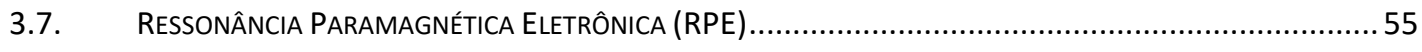

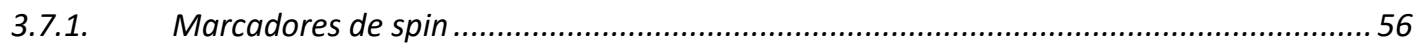

3.7.2. Marcação de spin sítio-dirigida ..................................................................... 58

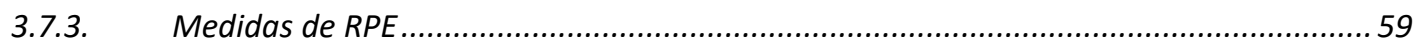

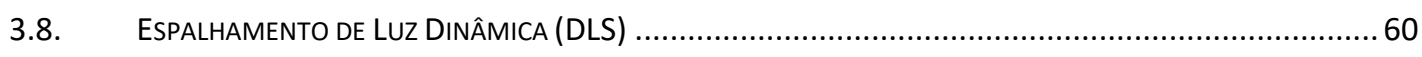




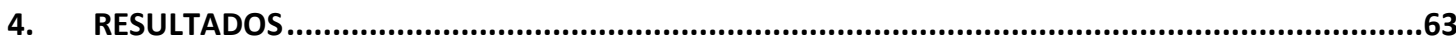

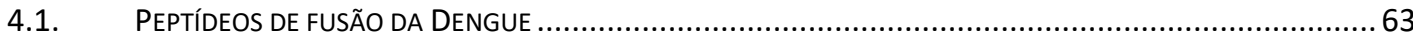

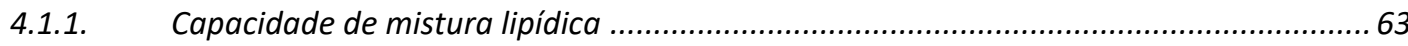

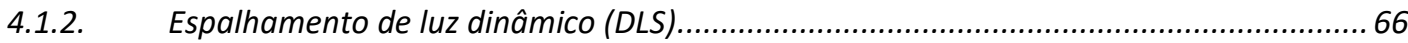

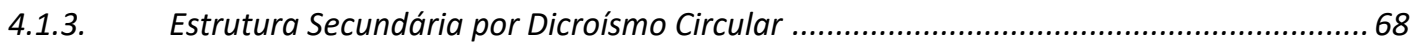

4.1.4. Constantes de partição e localização do $\operatorname{Trp}$ - Fluorescência ......................................... 72

4.1.5. Ressonância paramagnética eletrônica ........................................................................ 80

4.1.6. Calorimetria Diferencial de Varredura (DSC) ............................................................. 84

4.1.7. Simulações computacionais por Dinâmica Molecular ................................................... 88

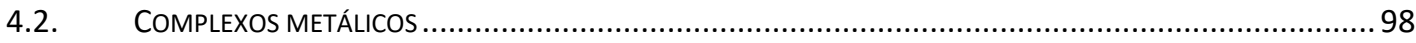

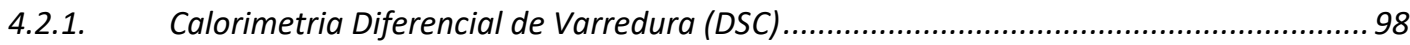

4.2.2. Análise dos parâmetros empíricos dos espectros de RPE ........................................ 103

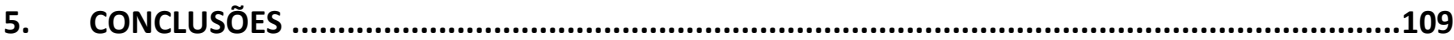

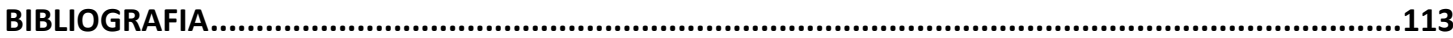

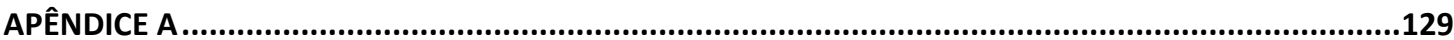

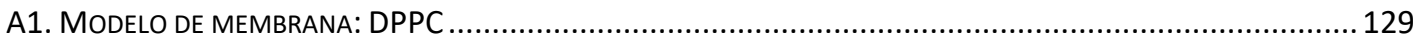

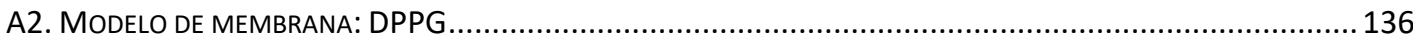

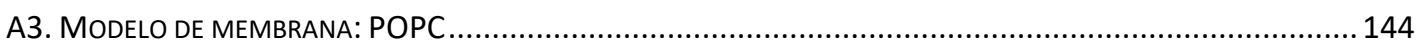

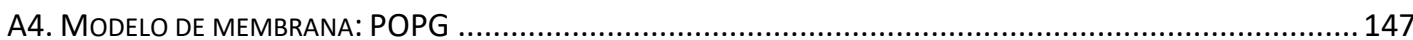






\section{Introdução}

A principal característica de todos os organismos vivos é que são constituídos por células envoltas por membranas, onde a função das membranas biológicas é delimitar tanto o espaço intracelular, quanto extracelular, definindo o dentro/fora da célula, bem como suas organelas. Tal compartimentalização é importante em muitos processos celulares e estabelece barreiras à comunicação e ao transporte através das membranas. (1) Ao longo dos anos foram propostos muitos modelos para o papel e a constituição das membranas celulares, assumindo-se a bicamada lipídica como base estrutural das membranas biológicas, e que representava uma estrutura rígida para a fixação das proteínas. Em 1972, o modelo do mosaico fluido conferiu uma certa dinâmica à membrana com as proteínas agora dispersas em um mar de moléculas lipídicas organizadas em uma bicamada lipídica (Figura 1). (2) Até hoje este é o modelo mais aceito para explicar a estrutura e dinâmica das membranas biológicas, porém nos últimos anos, alguns ajustes foram sendo propostos para os mecanismos de interação entre os lipídios e as proteínas. (3-6)

Devido ao papel tão fundamental e complexo das membranas biológicas, foram criadas muitas estratégias diferentes para o estudo destas, nas quais se retêm a estrutura essencial da bicamada lipídica, mas se simplificam o sistema para que os papéis dos componentes individuais possam ser avaliados e sua organização e dinâmica possa ser visualizada. Os lipossomos são altamente adequados para avaliar diferentes parâmetros biofísicos e são, de longe, os modelos mais utilizados para estudar as interações com membranas. Podem ser classificados de acordo com tamanho e lamelaridade por: vesículas multilamelares grandes (MLVs) e as vesículas unilamelares, que se dividem em pequenas (SUVs, 20-50 nm), grandes (LUVs. 50-100 nm) e gigantes (GUVs, 10-100 $\mu \mathrm{M}$ ). Enquanto as GUVs estão próximas do tamanho real das membranas celulares, as LUVs por sua vez possuem uma curvatura similar. (7) A escolha do tipo de lipossomo depende tanto do tipo de membrana a ser estudada, quanto da técnica a ser utilizada. Por exemplo, MLVs são uma boa escolha para técnicas como espalhamento de raio-X a baixos ou grandes ângulos (SAXS e WASX), calorimetria diferencial de varredura (DSC) e ressonância magnética nuclear e/ou 
paramagnética eletrônica (RMN e RPE, respectivamente), devido à grande quantidade de material neste tipo de lipossomos. Já as GUVs são candidatas a técnicas relacionadas à microscopia, e as LUVs e SUVs a técnicas relacionadas à absorção de luz, como fluorescência e dicroísmo circular (CD), devido ao fato de serem uniformes, levando a amostras mais homogêneas e evitando o espalhamento da luz que dificulta essas técnicas.

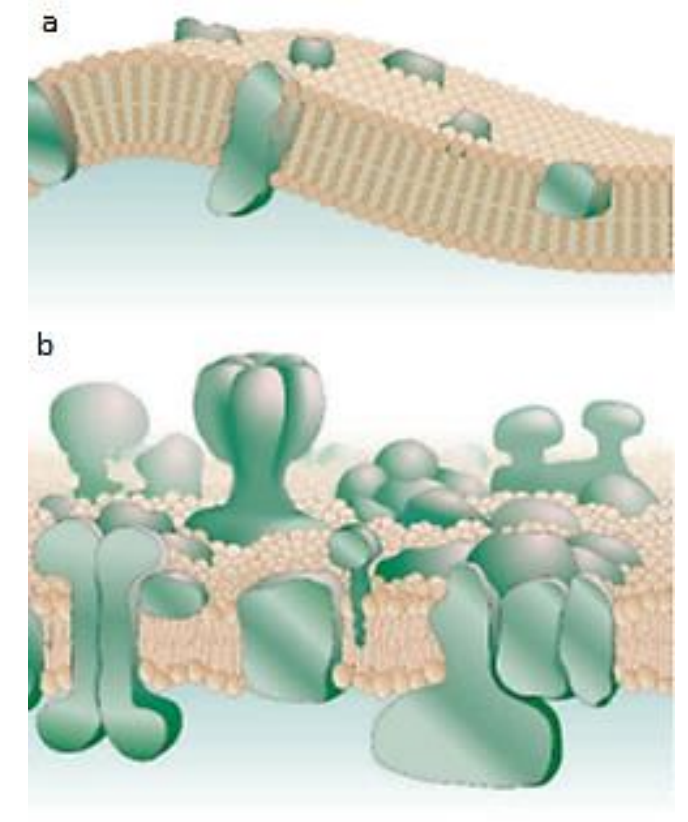

Figura 1 - Modelo para a estrutura da membrana. (a) - Modelo de mosaico-fluido de Singer-Nicholson. (b) Versão atualizada para o modelo da estrutura. Figura retirada de (3).

A presente tese teve como objetivo entender melhor o mecanismo de interação com miméticos de membranas de dois grupos diferentes de pequenas moléculas, que encontram seu ponto de intersecção em sua participação em doenças que afligem o ser humano. Onde o primeiro grupo atua na causa e o segundo grupo em uma potencial solução. Em ambos os grupos, o interesse geral reside no processo de transporte através da barreira representada pela membrana celular.

O primeiro grupo consiste no peptídeo de fusão do vírus da Dengue, onde vale ressaltar ser a mesma sequência do peptídeo de fusão do vírus Zika, situado no domínio II da glicoproteína $E$, além das regiões flanqueadoras a ele, do sorotipo 1 e 3 . Estudamos as variações na bicamada lipídica devido à interação com os peptídeos, através de 
experimentos de fluorescência, calorimetria diferencial de varredura (DSC), espalhamento da luz dinâmica (DLS). Realizamos também experimentos de dicroísmo circular (CD), que nos mostra a conformação da estrutura secundária dos peptídeos, tanto sozinhos, quanto na presença dos lipídios. Também foram feitas medidas de ressonância paramagnética eletrônica (RPE), onde observamos a interação peptídeo-membrana, tanto do ponto de vista dos miméticos, com as membranas marcadas por sondas paramagnéticas, quanto do ponto de vista dos peptídeos, utilizando da metodologia de marcação de spin sitio-dirigida (SDSL) com a sonda metanotiosulfonato (MTSSL). Para complemento dos resultados experimentais e fins de comparação, utilizamos também simulações por dinâmica molecular para entender um pouco melhor o processo de interação.

O segundo grupo de moléculas estudado são de compostos de coordenação, candidatos a drogas antitumorais, os complexos ternários dipeptídicos com Fenantrolina (phen), Cu(L-Ala-Phe)(phen) e Cu(L-Ala-Gly)(phen). Avaliamos a interação complexosmembrana através de experimentos de DSC e RPE, onde comparamos os efeitos dos compostos na bicamada ao longo da variação da temperatura, com os do ligante Fenantrolina (phen) sozinho, e do composto homoléptico, contendo apenas cobre e Fenantrolina, $[\mathrm{Cu}(\text { phen })]^{2+}$.

As etapas desenvolvidas neste trabalho de doutorado são detalhadas e organizadas nesta tese em 5 capítulos. No que se segue, apresentamos uma rápida revisão bibliográfica sobre o peptídeo de fusão do vírus da Dengue e compostos de coordenação, em especial complexos metálicos com phen, potenciais candidatos a fármacos quimioterápicos.

No capítulo 3, apresentamos as etapas desenvolvidas no trabalho experimental e computacional, com a descrição da preparação das amostras de interesse, além de alguns fundamentos teóricos das técnicas utilizadas e da metodologia para a análises dos resultados.

No capítulo4, temos a apresentação e discussão dos resultados obtidos em ambos os estudos desta tese, correlacionando-os com dados da literatura.

E por fim no capítulo 5 são discutidas as informações obtidas e detalhadas dos capítulos anteriores e as conclusões finais.

No apêndice a esta tese são apresentados alguns resultados experimentais obtidos nos experimentos de RPE. 


\section{Revisão bibliográfica}

Nesta seção apresentamos uma breve revisão bibliográfica sobre os dois grupos estudados nesta tese: peptídeo de fusão do vírus da Dengue, onde estudamos a sequência putativa do peptídeo de fusão e as regiões flanqueadoras dos sorotipos 1 e 3 e os compostos de coordenação, de cobre com Fenantrolina, que são candidatos a fármacos quimioterápicos.

\subsection{Dengue e o peptídeo de fusão}

Uma característica comum das doenças causadas por vírus é que elas surgem sem aviso prévio e podem se espalhar rapidamente, e com efeitos devastadores. Um exemplo são os mais recentes surtos na África, com o Ebola em 2014, e no Brasil, com o Zika em 2015 e a Febre Amarela em 2017. (8-10)

Neste trabalho nosso interesse é a Dengue, que é endêmica em mais de 100 países, com ocorrências mais comuns nas regiões do sudeste da Ásia, nas Américas, Pacífico Ocidental, África e Mediterrâneo Oriental. Sua rápida emersão global está relacionada às mudanças demográficas e sociais das últimas décadas, como o intenso crescimento populacional, aumento do movimento de pessoas, urbanização descontrolada, mudanças climáticas, além do colapso na infraestrutura da saúde pública e de programas de controle de vetores. (11) Estima-se que mais de 2,5 bilhões de pessoas estão em risco de serem infectadas e mais de 50 milhões de infecções ocorrem por ano no mundo todo. Há ainda estudos que mostram que pode haver até 28 vezes mais ocorrências de casos de dengue do que os reportados pelos sistemas de vigilâncias nacionais. (12)

A dengue é uma doença não contagiosa, causada pelo vírus da Dengue, tendo como vetores os mosquitos Aedes, sendo no Brasil, o Aedes aegypti, seu vetor principal, que é menos suscetível à infecção viral que o Aedes albopictus Podendo este ser um mecanismo 
de seleção para cepas mais virulentas do vírus, já que com a menor susceptibilidade é necessário uma maior carga viral no hospedeiro humano para infectar o mosquito. $(13,14)$

Até há pouco tempo conheciam-se quatro sorotipos diferentes do vírus, DENV-1 a 4, que compartilham cerca de $60-65 \%$ de sua identidade em nível da estrutura primária, e, portanto, são vírus distintos. (15) Em 2013, foi isolado o quinto sorotipo, detectado durante análises de uma amostra viral coletada de um fazendeiro da Malásia em 2007, onde foi visto que o DENV-5 é geneticamente similar aos outros quatro sorotipos, mas ainda não se sabe claramente se o vírus é capaz de sustentar a transmissão em humanos. $(16,17)$ Cientistas supõem que os vírus da dengue evoluíram em primatas não-humanos e saltaram desses primatas para humanos na África ou no sudeste da Ásia entre 500 e 1.000 anos atrás.

Após a incubação do vírus, entre 4 a 10 dias, a infecção pode produzir um amplo espectro de sintomas, como febre alta, enjoos, dores no fundo dos olhos, manchas vermelhas na pele em todo o corpo, dores nas articulações e ossos e sangramentos pelo nariz, olhos e gengivas, embora a maioria das infecções sejam assintomáticas. $(18,19)$

A infecção primária a um dos sorotipos confere imunidade permanente ao mesmo, no entanto, é geralmente fraca às outras cepas, durando de 2 a 3 meses, no máximo. As formas mais graves da doença, denominada Dengue Hemorrágica ou Síndrome de Choque da Dengue, ocorrem devido à reinfecção, nas quais os anticorpos existentes anteriormente não neutralizam o sorotipo diferente do vírus, aumentando assim a infecção e facilitando a penetração do vírus nas células do hospedeiro, podendo levar à morte, principalmente em crianças. $(20,21)$

Ainda não há tratamento antiviral específico e totalmente eficaz para a dengue. 0 manejo da doença faz-se com o acompanhamento clínico, principalmente no monitoramento criterioso da reposição do volume intravascular, que pode reduzir a fatalidade da doença. (22) Ainda hoje, a melhor abordagem para controlar e prevenir a transmissão do vírus é através de intervenções direcionadas ao vetor. (23)

O grupo farmacêutico Sanofi Pasteur trabalha no desenvolvimento de uma vacina tetravalente contra a dengue há cerca de vinte anos. Atualmente, a vacina Dengvaxia está na fase 3 de testes em diversos países da Ásia e América Latina, porém após o aumento da incidência de casos severos da doença em pessoas vacinadas, que nunca haviam sido 
infectadas, os testes com a nova vacina estão sendo recomendados apenas para pessoas com histórico de infecção de dengue confirmada anteriormente. (24-26)

O vírus da dengue pertence à família Flaviviridae, do gênero Flavivírus, que inclui mais de 70 vírus diferentes, em que mais da metade estão associados a doenças humanas, sendo os principais vetores mosquitos e carrapatos. (27)

Os flavivírus são vírus envelopados e pequenos, cerca de $50 \mathrm{~nm}$, de fita simples positiva de RNA, que contêm aproximadamente 10.700 nucleotídeos (Figura 2). Sua tradução resulta em uma poliproteína, contendo 3.411 aminoácidos, que é modificada na co- e pós-tradução, produzindo três proteínas estruturais: capsídeo (C - 120 aminoácidos), membrana ( $M$ - 75 aminoácidos, que é expressada como prM, um precursor de $M$ ) e envelope (E - 495 aminoácidos). A proteína C está envolvida com o acondicionamento do genoma viral e forma a parte central do nucleocapsídeo. Já prM (165 aminoácidos) e são glicoproteínas e cada uma contém duas hélices transmembranas. A proteína prM, durante a sua passagem pelo complexo de Golgi sofre clivagens pela enzima furino protease, promovendo a reorganização da superfície do vírus e resultando na capacidade de induzir a fusão celular. (28) Além dessas, existem ainda sete proteínas não-estruturais (NS1, NS2a, NS2b, NS3, NS4a, NS4b e NS5), as quais são essenciais para a replicação do vírus dentro da célula hospedeira. $(29,30)$

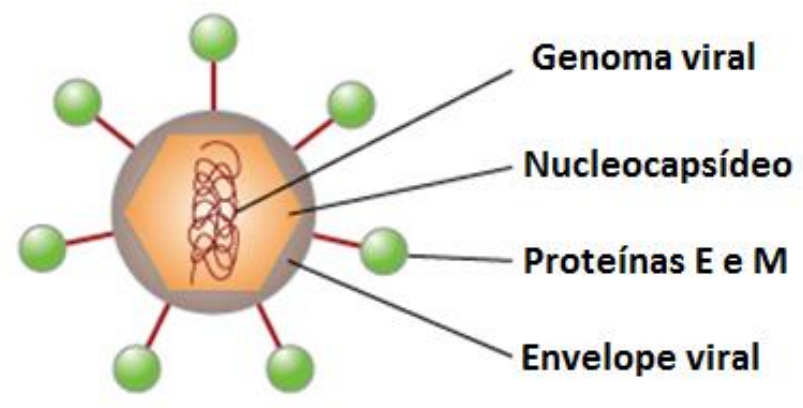

Figura 2 - Estrutura do vírus da dengue. Dentro do vírus está o nucleocapsídeo, que contém o genoma viral e é cercado pelo envelope viral, uma bicamada lipídica que é retirada do hospedeiro. As proteínas $\mathrm{E}$ e $\mathrm{M}$ atravessam a membrana e protegem a camada externa que controla a entrada do vírus em células humanas. Figura adaptada de (31). 
Vírus envelopados normalmente entram nas células hospedeiras através da fusão das membranas mediada pela glicoproteína $E$, situada na superfície do envelope viral. Esta proteína possui três domínios: I, II e III, basicamente estruturados em folhas- $\beta$ (Figura 3) e compartilham, entre os sorotipos, uma sequência interna situada no domínio II, conhecida como peptídeo de fusão. Tal sequência é altamente conservada nos flavivírus (32) e compreende os resíduos 98 a 113, tendo como estrutura primária DRGWGNXCGXFGKGXX, onde $0 \mathbf{X}$ representa os resíduos de aminoácidos que variam entre os diferentes vírus (33), na Tabela 1 são apresentados alguns exemplos. Esse peptídeo de fusão, contendo uma sequência altamente hidrofóbica e em forma de loop, é responsável pela interação direta dos domínios da proteína de fusão com a membrana alvo, quando a conformação fusogênica é ativada. (34). Na Figura 4 mostramos uma representação do loop de fusão e das regiões flanqueadoras referentes aos sorotipos 1 e 3 da Dengue.

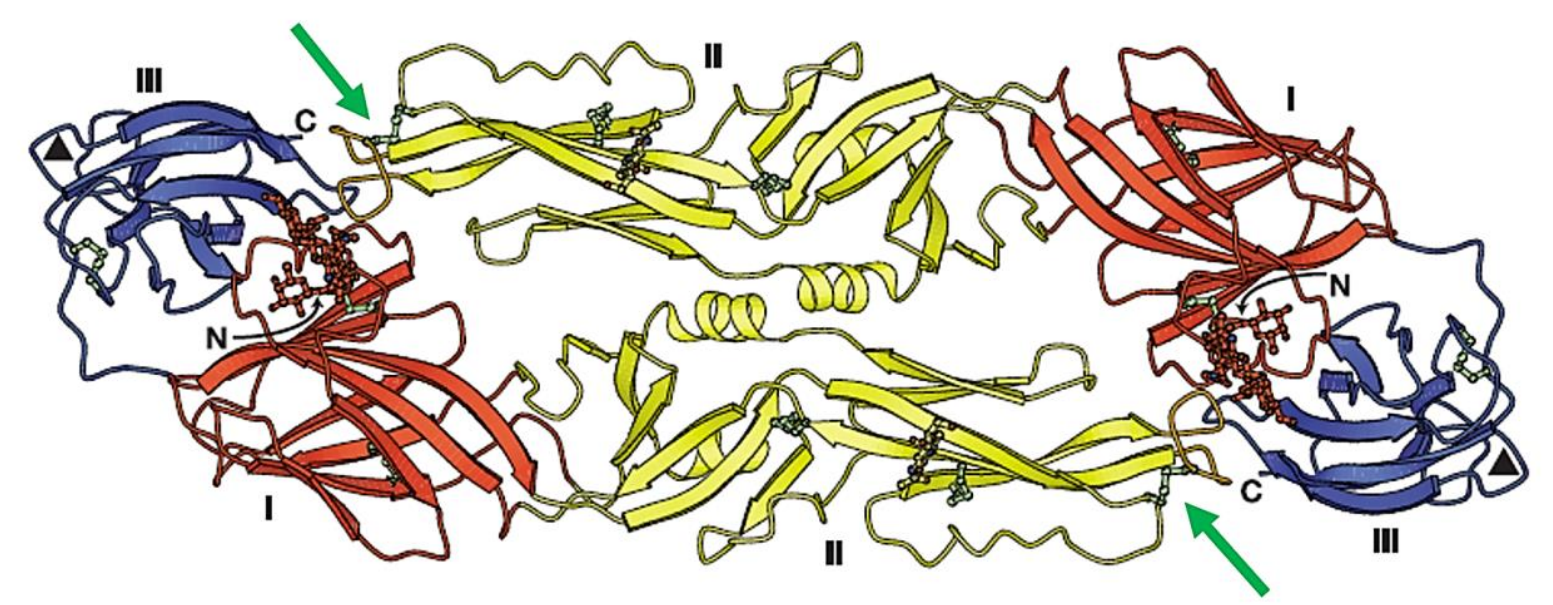

Figura 3 - Os três domínios da glicoproteína E do envelope viral do sorotipo 3 da dengue. Domínio I em vermelho, domínio II em amarelo e domínio III em azul. A região do peptídeo de fusão está destacada com as setas em verde. Figura adaptada de (35).

É importante ressaltar que a escolha da sequência primária do peptídeo de fusão é baseada na conservação dos aminoácidos entre os flavivírus, tendo já sido estudada como sendo os resíduos de 98-120, 98-110 e 99-116 da glicoproteína E. (36-38) E em nosso caso foi escolhida devido a igualdade da sequência para ambos os sorotipos 1 e 3 da Dengue, além do vírus Zika. 
Tabela 1 - Sequências nativas de peptídeos de fusão de alguns flavivírus, transmitidos por diferentes vetores (mosquitos e carrapatos). Os aminoácidos em negrito são as mudanças que ocorrem de uma sequência para outra. Tabela adaptada de (33).

\begin{tabular}{|cc|}
\hline Flavivírus & Sequência primária nativa \\
\hline Dengue Tipo 1 & DRGWGNGCGLFGKGSL \\
\hline Dengue Tipo 2 & DRGWGNGCGLFGKGGI \\
\hline Dengue Tipo 3 & DRGWGNGCGLFGKGSL \\
\hline Dengue Tipo 4 & DRGWGNGCGLFGKGGV \\
\hline Zika $^{\text {Didos por carrapato }}{ }^{\text {a }}$ & DRGWGNGCGLFGKGSL \\
\hline Powassan $^{\text {b }}$ & DRGWHNGCGLFGKGSI \\
\hline Transmitido $^{2}$ & DRGWHNGCGFFGKGSI \\
\hline
\end{tabular}

${ }^{a}$ exceto Powassan; ${ }^{b}$ incluindo o carrapato de veado

Nos vírus maduros, a glicoproteína $\mathrm{E}$ forma dímeros que se depositam na membrana viral. A determinação da estrutura dessa proteína na conformação pós-fusão revela que os dímeros são convertidos a trímeros, com o peptídeo de fusão localizado na extremidade do trímero. O mecanismo fusional propõe que a conversão de dímeros para trímeros é um processo que envolve dois passos: o primeiro sendo uma dissociação reversível dos ectodomínios, que são importantes para a exposição da extremidade do domínio II (que é a sequência putativa do peptídeo de fusão), tornando-a acessível às interações com a membrana alvo; e o segundo passo é a trimerização, processo irreversível. Acredita-se que este processo forneça energia para "puxar" as membranas revestidas e conduzir à fusão da membrana (Figura 5). Além disto, três resíduos são indispensáveis para esta interação: triptofano (Trp 101), leucina (Leu 107) e fenilalanina (Phe 108), os quais estão totalmente expostos à superfície molecular, próximo ao eixo de trímeros formado, denominados de tríade hidrofóbica, pois são responsáveis por manter a conformação de loop entre as glicinas nas posições 102 e 106, promovendo a inserção do peptídeo de fusão na membrana 
endossomal hospedeira. Após isto, o nucleocapsídeo pode ser liberado no citoplasma. (39, 40)

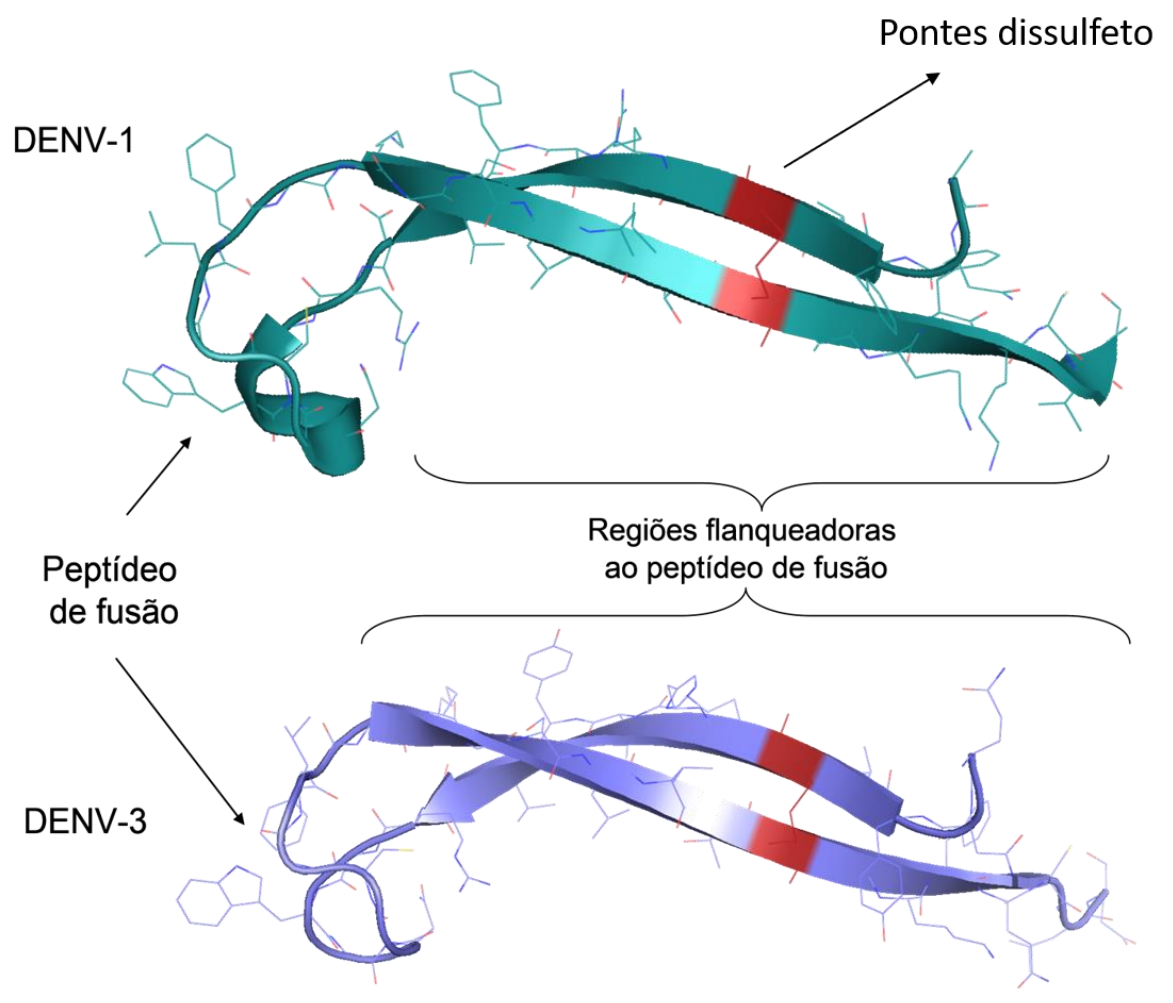

Figura 4 - Representação dos peptídeos DENV-1 e DENV-3, contendo o peptídeo de fusão, representado pelo "loop" que está indicado pela seta na figura apresentada. Destacado em vermelho estão representadas as ligações dissulfeto que estabilizam as regiões flanqueadoras ao peptídeo de fusão. Figura elaborada pela autora e produzida por meio do software PyMOL.

Porém, o mecanismo exato de como as proteínas de fusão de membrana medeiam a fusão real das membranas e o papel preciso dos peptídeos de fusão nesse processo ainda não está claro. Logo, a importância de estudos como este para tentar elucidar o processo a nível molecular, em que interações dos peptídeos com membranas modelo podem ser o primeiro passo para o entendimento das mudanças estruturais da ligação peptídeomembrana. 

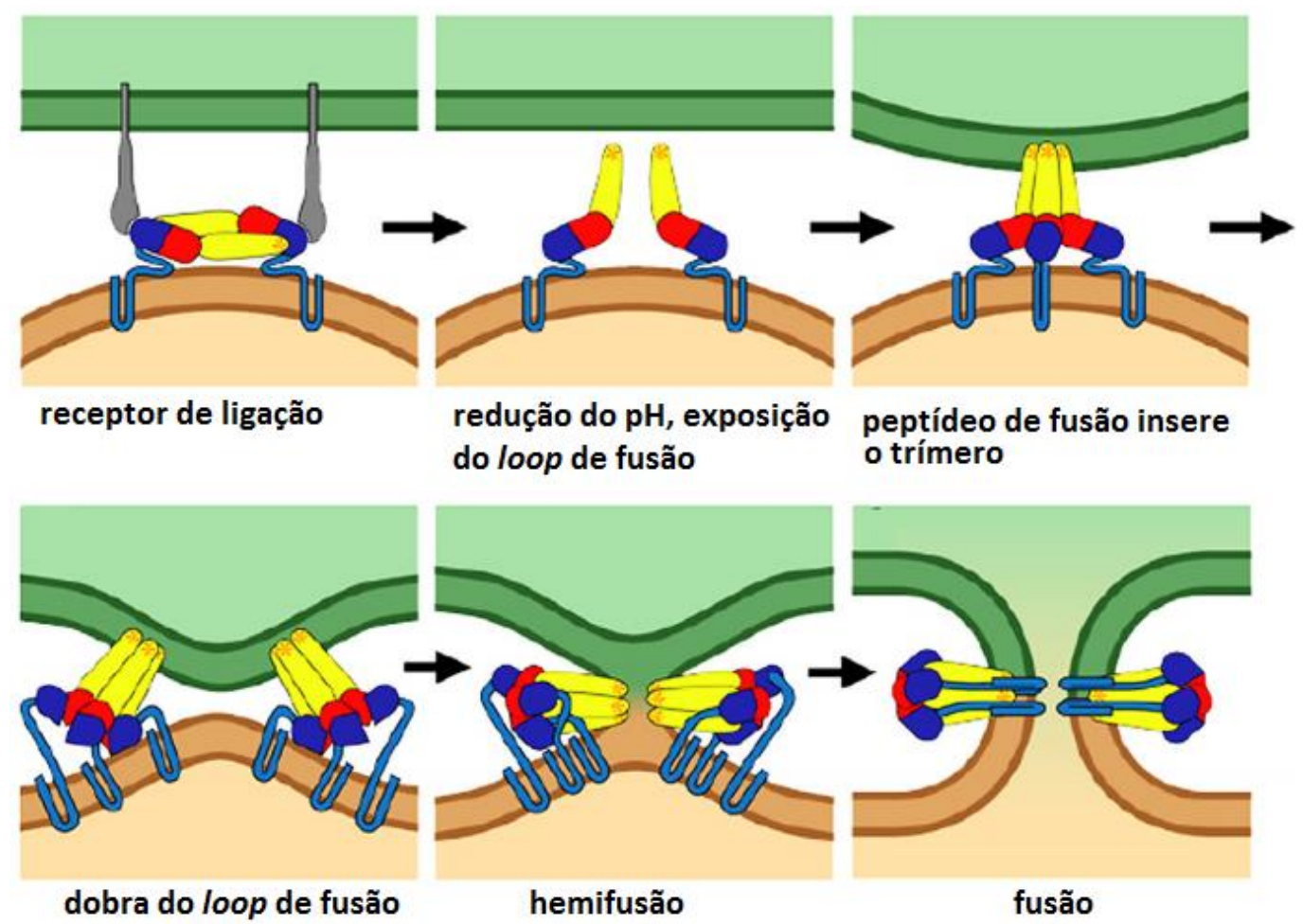

Figura 5 - Mecanismo proposto para a fusão das membranas. Figura adaptada de (41).

\subsection{Compostos de coordenação: cobre, Fenantrolina e dipeptídeos}

Há relatos do uso terapêutico de compostos metálicos de cerca de 4 a 5 mil anos. Os chineses acreditavam que o ouro, por ser um metal nobre, trazia benefícios à saúde. No século 15, Paracelsus, um famoso alquimista, utilizava a mistura de vários metais pesados, como o ferro, cádmio, arsênio e mercúrio, para o tratamento de seus pacientes. (42)

Com a descoberta dos compostos de coordenação de metais de transição e da Teoria da Química de Coordenação, no final do século 19, por Werner, essas moléculas começaram a ser amplamente estudadas. E ganhou impulso, com a introdução, por Ehrlich, considerado o criador da quimioterapia moderna, de um composto com várias combinações de arsênio para o tratamento da sífilis, sendo bem-sucedida e utilizada até a descoberta da penicilina. 
O composto de coordenação cis-diaminodicloroplatina (II), conhecido como cisplatina, vem sendo utilizada na quimioterapia, por quase 40 anos, contra vários tipos de câncer, como os de ovários, cabeça e pescoço, bexiga e linfomas. Porém, alguns efeitos colaterais e o surgimento de resistência tumoral ao longo do tratamento vem limitando suas aplicações. (44)

O sucesso obtido com a cisplatina e outros compostos contendo a platina para o tratamento de câncer levou a intensas pesquisas sobre a possível utilidade de novas moléculas contendo elementos tipicamente inorgânicos para esse fim, principalmente compostos de coordenação, com metais essenciais. A hipótese seria de que complexos com esses íons poderiam levar a compostos de menor toxicidade, devido à pré-existência de vias estabelecidas de absorção, distribuição e armazenamento no organismo, com enzimas e proteínas específicas para cada metal geneticamente destinado para esses fins.

Aproximadamente um terço de todas as proteínas e enzimas contêm e/ou necessitam de um ou mais metais para realizar suas funções especificas. Onde o cálcio, sódio, potássio e magnésio, que estão presentes em larga escala nos organismos, são essências para os animais e plantas; além dos metais traços: cobre, vanádio, cromo, manganês, molibdênio, ferro, cobalto, níquel e zinco, que aparecem em pequenas quantidades. (45) A carência ou excesso desses metais pode produzir desordens metabólicas, enfermidades e outras disfunções. Um exemplo é a deficiência de ferro que resulta na anemia perniciosa, já a ingestão por acidente ou suplementação em excesso do mesmo pode acarretar em envenenamento. (46)

O estudo de novos compostos de coordenação com metais que participe endógena ou exogenamente de processos do organismo vivo, se mostra importante para a obtenção de novos compostos de suplementação na deficiência dos mesmos. Além de poder melhorar a disponibilidade dos fármacos, eliminando os efeitos secundários de resistência ou aumentando a estabilidade de um medicamento no corpo. $(47,48)$ A síndrome de Menkes, por exemplo, que é hereditária, afeta os níveis de cobre no organismo, onde o complexo $\left[\mathrm{Cu}(\mathrm{His})_{2}\right]$ vem sendo utilizado para reverter esta deficiência. (49)

Atualmente, no desenvolvimento de novos agentes quimioterápicos, prioriza-se a busca por compostos com alvos moleculares específicos, ao contrário de compostos com baixa seletividade em termos de seus alvos moleculares, como muitos dos fármacos 
metálicos em uso clínico e em pesquisa já existentes. Entre os metais essenciais para os quais foram desenvolvidos compostos com importante atividade antitumoral estão o Cu (II), Co (II) e Fe (II).

O cobre é provavelmente um dos metais de transição cuja química de coordenação foi mais estudada, possuindo compostos em fases clínicas de investigação. $(50,51)$ Dos metais de transição, é caracterizado como o menos reativo, apresentando estados de oxidação de 0 a +4. Atualmente é utilizado no desenvolvimento de compostos organometálicos aplicados à catálise homogênea, compostos de cobre (III) com tetrapeptídeos estáveis em solução aquosa, além de óxidos e fluoretos de cobre (IV). Devido à diversidade de estados de oxidação que determinam a geometria e o índice de coordenação, o cobre possui uma grande variedade estrutural. (52-54)

A participação do cobre em numerosos processos biológicos é reconhecida, integrando os centros redox ativos de várias proteínas e em meio biológico é predominantemente coordenado para três tipos de ligantes: histidina, cisteína e resíduos de metionina. (55)

Existem inúmeros relatos de níveis elevados de Cu (II) para pacientes com câncer, devido ao fato de estar ativamente envolvido nos processos de vascularização dos tumores; logo uma das estratégias é o uso de agentes complexantes para remoção do íon. (56)

A biodisponibilidade e distribuição no organismo dos compostos de coordenação também depende dos ligantes utilizados, que são capazes de promover variações significativas no metabolismo dos íons metálicos. Na busca de compostos menos tóxicos do que a cisplatina, tem aumentado os estudos de novas moléculas, com ligantes como a Fenantrolina (phen), que é um ligante quelante de metais, dando origem a complexos estáveis, apresentando atividade biológica contra células cancerígenas e alguns microrganismos. $(57,58)$ Em especial, o mecanismo molecular de ação de compostos derivados de Cu-phen inclui ligação ao DNA e produção de espécies reativas ao oxigênio levando a morte celular. $(51,59,60)$ As Casiopeínas, desenvolvidas por Ruiz e colaboradores são um dos exemplos de sucesso desses complexos de Cu-phen, onde algumas delas estão na fase de testes clínicos no México. (61)

Neste trabalho estudamos complexos ternários de Cu-phen e dipeptídeos (Ala-Phe e Ala-Gly) com potencial aplicação para o tratamento de câncer. As moléculas foram 
sintetizadas pelo grupo da Prof(a). Dr(a). Gianella Facchin, que estudam há algum tempo esses tipos de compostos. (62-65) Estudos anteriores desses complexos mostraram que o ligante de phen está exposto e supostamente disponível para interação com moléculas biológicas e o ambiente de coordenação do metal observado no estado solido é mantido em solução aquosa. Eles observaram que todos os complexos são ativos contra as linhas celulares tumorais testadas. Além do ligante de phen melhorar a citoxicidade comparado aos análogos dos complexos Cu-dipeptídeo homolépticos, sendo o [Cu(Ala-Phe)(phen)] o mais citotóxico contra as linhas celulares de câncer, mais até que a cisplatina, podendo ser um bom candidato a testes de atividade antitumorais in vivo. Porém, nenhuma relação com a maior citotoxicidade e a interação com o DNA foram estabelecidas. (66) A procura de melhor entendimento da base molecular que modula sua atividade, neste trabalho estudamos a interação dos compostos Cu(L-Ala-Gly) e Cu(L-Ala-Phe) com miméticos de membranas. Além da interação com o ligante sozinho, phen, e as espécies homolépticas $[\mathrm{Cu}(\text { phen })]^{2+}$, considerando que são fragmentos comuns em uma infinidade de compostos com atividade biológica, bem como para fins comparativos.

A interação de compostos biologicamente ativos com membranas celulares influencia sua biodisponibilidade, mesmo quando as membranas não são consideradas alvo biológico deste tipo de compostos. Por exemplo, há uma crescente conscientização sobre a importância dos mecanismos de absorção celular e efluxo como fatores que controlam a resistência clínica aos medicamentos de platina. (67) Também pode ser o determinante da atividade antitumoral observada como recentemente proposto para alguns dos compostos da família Casiopeína (68). Neste caso, a posição dos grupos metila no ligante de Fenantrolina comprovadamente influencia fortemente a atividade in vivo, que parece ser modulada pela capacidade diferente dos complexos de serem retidos na membrana celular como sugerido pela dinâmica molecular. Em contraste com o grande número de estudos sobre a interação dos compostos de coordenação com o DNA, existem poucos relatos de estudos experimentais sobre a interação desses compostos com modelos de membranas lipídicas. $(69,70)$ 


\section{Materiais e métodos}

Neste capítulo serão descritos todos os procedimentos envolvidos nas preparações das amostras, algumas considerações teóricas sobre as técnicas empregadas e as metodologias utilizadas para o tratamento e análises dos dados experimentais obtidos.

\subsection{Fosfolipídios e sondas}

Os fosfolipídios, bem como as sondas fluorescentes e paramagnéticas, foram adquiridos comercialmente das empresas Avanti Polar Lipids e Sigma Chemical. Todos esses materiais foram utilizados sem outros procedimentos de purificação que não aqueles realizados pelos respectivos fabricantes e estão apresentados na Tabela 2 e suas estruturas químicas na Figura 6.

\subsubsection{Preparação dos lipossomos}

Os lipossomos são preparados através do método de hidratação de filmes finos. (71) Os lipídios são dissolvidos em clorofórmio/metanol (2/1, v/v) e misturados nas proporções adequadas, em um tubo de vidro e evaporados sob fluxo de gás nitrogênio. Em seguida, são submetidos à centrifugação sob vácuo em um Speedvac da empresa Savant, modelo SC200, por pelo menos duas horas, para a garantia da eliminação dos resíduos dos solventes orgânicos. Após isto, os filmes são hidratados com volume adequado de solução tampão 5 mM HEPES, 10 mM MES, em pH apropriado (5 ou 7,4), no caso dos estudos dos peptídeos de fusão e tampão HEPES pH 7,4 para os estudos dos complexos metálicos. Então, as dispersões lipídicas são agitadas em vórtex a fim de produzir vesículas multilamelares (MLVs). Para a formação de vesículas unilamelares grandes (LUVs), as MLVs são sujeitas a ciclos de freezethaw, mergulhando-se o tubo com a solução lipídica em nitrogênio líquido e, em seguida, em 
um banho quente, com temperatura acima da transição de fase dos lipídios utilizados, para o rápido descongelamento, a fim de aumentar a eficiência de encapsulamento da solução aquosa. Após esta etapa, a solução é submetida a um sistema de alta pressão utilizando um extrusor, contendo filtro de policarbonato com poros de $100 \mathrm{~nm}$ de diâmetro, ambos adquiridos da empresa Avanti Polar Lipids. Para a homogeneização do tamanho das vesículas, foram realizados, no mínimo, 11 ciclos de extrusão nas membranas de policarbonato. Os tamanhos das vesículas foram confirmados posteriormente por experimentos de espalhamento de luz dinâmico através do equipamento Zetasizer $\mu V$ da empresa Malvern Instruments.

Tabela 2 - Fosfolipídios, sondas fluorescentes e paramagnéticas, utilizadas neste trabalho, adquiridos comercialmente. Tabela elaborada pela autora.

\begin{tabular}{|c|c|c|}
\hline & Material & Sigla \\
\hline \multirow{4}{*}{ Fosfolipídios } & 1-palmitoil-2-oleoil-sn-glicero-3-fosfocolina & POPC \\
\hline & $\begin{array}{l}\text { 1-palmitoil-2-oleoil-sn-glicero-3-fosfo-(1'-rac- } \\
\text { glicerol) }\end{array}$ & POPG \\
\hline & 1,2-dipalmitoil-sn-glicero-3-fosfocholina & DPPC \\
\hline & 1,2-dipalmitoil-sn-glicero-3-fosfo-(1'-rac-glicerol) & DPPG \\
\hline \multirow{2}{*}{ Sondas fluorescentes } & $\begin{array}{l}\text { 1,2-dipalmitoil-sn-glicero-3-fosfoetanolamina-N- } \\
\text { (7-nitro-2-1,3-benzoxadiazol-4-il) }\end{array}$ & NBD-PE \\
\hline & $\begin{array}{l}\text { 1,2-dipalmitoil-sn-glicero-3-fosfoetanolamina-N- } \\
\text { (lissamina rodamina B sulfonil) }\end{array}$ & Rh-PE \\
\hline \multirow{3}{*}{$\begin{array}{c}\text { Marcadores } \\
\text { paramagnéticos }\end{array}$} & 1-palmitoil-2-estearoil-(n-doxil)-fosfatidilcolina & $\begin{array}{c}n=5,7,10,12 \\
14 \text { e } 16-P C S L\end{array}$ \\
\hline & 1,2-dioleoil-sn-glicero-3-fosfo(tempo)colina & DOPTC \\
\hline & $\begin{array}{l}\text { S-(1-oxil-2,2,5,5-tetrametill-2,5-dihidro-1H- } \\
\text { pirrol-3-il)metil-metanosulfonotiato }\end{array}$ & MTSSL \\
\hline
\end{tabular}

Os lipossomos marcados, para as medidas de mistura lipídica (fluorescência) e RPE, são preparados através do mesmo protocolo descrito acima, onde são adicionadas quantidades (\% em massa) adequadas das sondas fluorescentes (1\%) ou paramagnéticas 
$(0,5 \%)$ em clorofórmio, antes da secagem do filme lipídico, a fim de se obter as devidas razões molares marcador/lipídio.

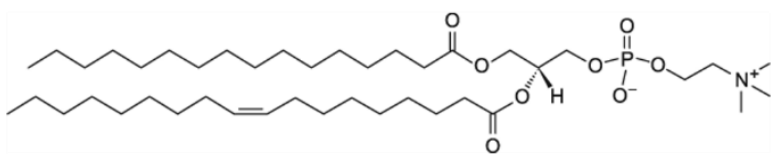

POPC

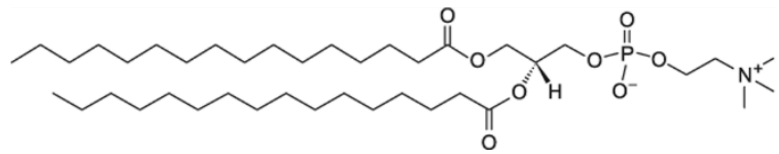

DPPC

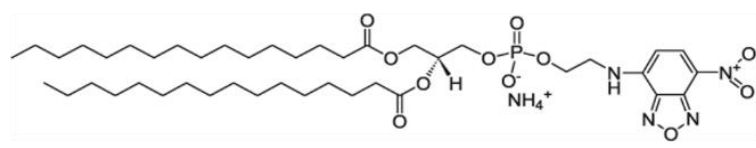

NBD_PE

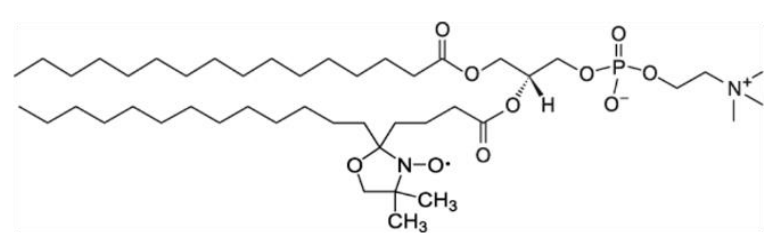

5-PCSL

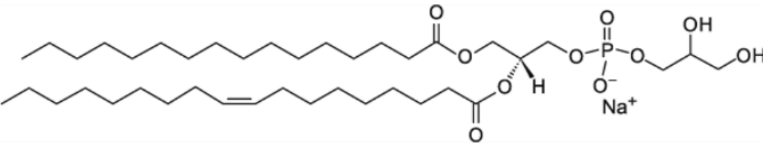

POPG

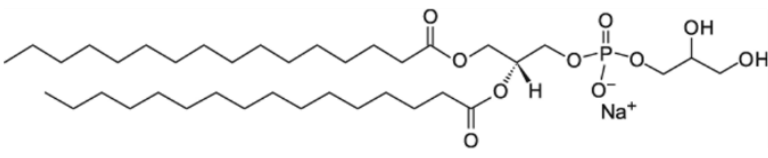

DPPG

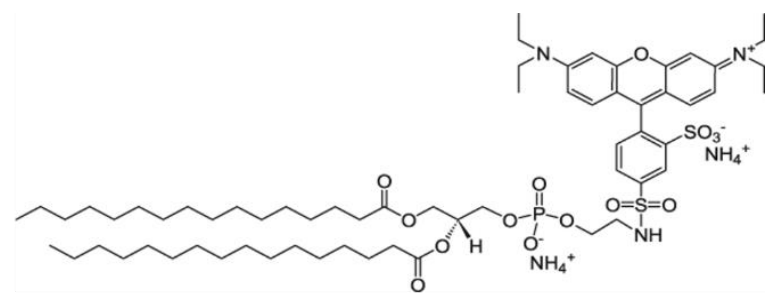

Rh-PE

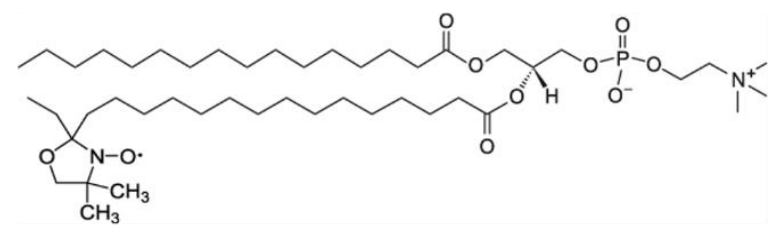

16-PCSL

Figura 6 - Estruturas químicas de todos os fosfolipídios e sondas fluorescentes e dois exemplos dos marcadores paramagnéticos n-PCSL utilizados neste trabalho. Figura adaptada de (72).

\subsection{Peptídeos}

Os peptídeos de interesse do presente trabalho correspondem à sequência putativa do peptídeo de fusão, resíduos 98-113, do domínio II da glicoproteína E do vírus da Dengue. Além do peptídeo de fusão em si, estudamos a influência da presença de suas regiões 
flanqueadoras, resíduos 88-123 dos sorotipos 1 e 3 da Dengue, cujas sequências primárias estão mostradas na Figura 7.

DENV-1 (88-123)

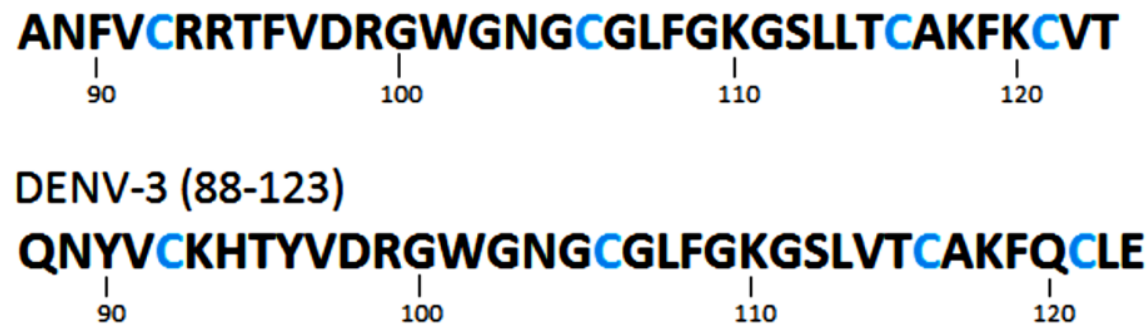

Figura 7 - Sequências primárias nativas dos peptídeos DENV-1 (88-123) e DEN-3 (88-123) contendo o peptídeo de fusão (98-113) e suas regiões flanqueadoras. Nota-se que as cisteínas (destacadas em azul) situam-se na mesma posição, em ambas as sequências dos sorotipos 1 e 3: 92, 105, 116 e 121 . Figura elaborada pela autora.

Os peptídeos DENV-1C e DENV-3C (Tabela 3) foram adquiridos comercialmente da empresa GenOne Biotechnologies, já sintetizados e ciclizados com a formação da ponte dissulfeto, que é uma ligação covalente resultante da junção de dois grupos sulfidrilas através da sua oxidação, formada entre as cisteínas 92 e 116 de ambas as sequências. Essa ligação é responsável pela formação do loop do peptídeo de fusão, quando inserido na glicoproteína E.

Os outros peptídeos utilizados neste trabalho, DENV-1S, DENV-3S, PFDEN (Tabela 3) e os análogos paramagnéticos, foram sintetizados em colaboração com o grupo do Prof. Dr. Eduardo Cilli, do Instituto de Química da Universidade Estadual Paulista "Júlio de Mesquita Filho", campus de Araraquara, onde fiz um breve estágio para aprender os protocolos de síntese de peptídeos por fase sólida, e pelo Prof. Dr. Eduardo Festozo Vicente, da Faculdade de Ciências e Engenharia, da Universidade Estadual Paulista "Júlio de Mesquita Filho", campus de Tupã.

Com o intuito de se estudar a dinâmica e as modificações causadas pelo mimético de membrana no peptídeo de fusão foram sintetizadas as sequências PFDEN e, em seguida, realizado o procedimento de marcação de spin de sítio dirigida (SDSL) com o reagente metanotiosulfonato (MTSSL), processo que será descrito na seção 3.7.2. 
Tabela 3 - Estrutura primária dos peptídeos estudados neste trabalho. Os resíduos destacados em vermelho se referem às substituições cisteína-serina que foram realizadas para a conveniência da síntese e/ou do estudo. Tabela elaborada pela autora.

\begin{tabular}{|cc|}
\hline & Sequência \\
\hline DENV-1C & ANFVC*RRTFVDRGWGNGSGLFGKGSLLTC*AKFKSVT \\
\hline DENV-1S & ANFVSRRTFVDRGWGNGSGLFGKGSLLTSAKFKSVT \\
\hline DENV-3C & QNYVC*KHTYVDRGWGNGSGLFGKGSLVTC*AKFQSLE \\
\hline DENV-3S & QNYVSKHTYVDRGWGNGSGLFGKGSLVTSAKFQSLE \\
\hline PFDEN & DRGWGNGCGLFGKGSL \\
\hline Cys $^{105}$ (MTSSL)PFDEN & DRGWGNGC ${ }^{\text {MTSSLGLFGKGSL }}$ \\
\hline Ser $^{105}$ Cys $^{112}$ (MTSSL)PFDEN & DRGWGNGSGLFGKGMTSSLL \\
\hline
\end{tabular}

Obs.: * cisteínas que formam a ponte dissulfeto.

Destacando que as sequências DENV-nC e DENV-nS ( $n=1$ ou 3) foram sintetizadas com o intuito de comparação e estudo da importância da ponte dissulfeto formada pelas cisteínas nas posições 92 e 116.

O processo de síntese dos peptídeos inicia-se com a construção da sequência de aminoácidos, seguido da clivagem dos subprodutos e termina com a purificação do produto final. Cada etapa da síntese requer procedimentos e técnicas particulares que serão descritos a seguir.

\subsubsection{Síntese dos peptídeos}

Para a síntese dos peptídeos, utilizamos a metodologia denominada "Síntese de Peptídeos em Fase Sólida" (SPFS) (73), que se baseia no crescimento, resíduo por resíduo, da cadeia peptídica ligada covalentemente pelo seu aminoácido carboxi-terminal aos sítios reativos existentes em um suporte sólido polimérico (resina). A estratégia utilizada, e mais 
empregada atualmente, é a da química Fmoc, que tem como princípio utilizar o grupo 9fluorenilmetiloxicarbonila (Fmoc) como protetor temporário da porção N-terminal dos aminoácidos. (74) As cadeias laterais reativas dos aminoácidos também são protegidas por compostos estáveis à base utilizada, como os grupos $t$-butiloxicarbonila, tritila e t-butila, que são lábeis ao ácido trifluoracético (TFA). As reações são realizadas em placas porosas, permitindo a separação da resina e dos componentes em solução por simples filtração. Para a realização do acoplamento, os grupos carboxila dos aminoácidos devem ser ativados por reagentes ativantes, usados geralmente em excesso. Logo, a síntese obedece a um ciclo de desproteção (retirada do grupo Fmoc), onde utilizamos piperidina, seguida de acoplamento do aminoácido, com lavagens intercaladas, com diclorometano (DCM) e dimetilformamida (DMF), para a retirada dos subprodutos, até o término da sequência desejável, sendo o próximo passo, a clivagem. Para obter o peptídeo na forma livre, a amida é clivada usando condições fortemente ácidas. Após esta etapa, o peptídeo separado é então liofilizado, obtendo-se o peptídeo bruto.

Para a síntese dos peptídeos utilizados neste trabalho (DENV-1S, DENV-3S, PFDEN) usou-se a resina Rink Amida, própria da técnica Fmoc. Foi usado um excesso de 2 vezes de aminoácidos e agentes acoplantes diisopropilcarbodiimida (DIC)/N-hidroxibenzotriazol (HOBt). A mistura foi agitada durante duas horas, utilizando como solvente uma mistura de $20 \%$ de DCM em DMF. A desproteção do grupo amino após o acoplamento (retirada do grupo Fmoc base-lábil) foi feita por uma solução de $20 \%$ de piperidina em DMF por 20 minutos. As lavagens entre cada passo para a retirada dos subprodutos foram feitas com DMF e DCM. Todos os aminoácidos e ativadores foram adquiridos comercialmente das empresas NovaBiochem Corp, Synpep e Advanced Chem Tech; os solventes utilizados foram adquiridos do laboratório LabSynth e da empresa Acros Organics. O monitoramento do sucesso das etapas de acoplamento ou desproteção foi realizado pelo teste de Kaiser, também conhecido como teste de Ninidrina, que seria um teste de cor para monitorar a integridade do acoplamento de aminoácidos, onde uma cor azul intensa é gerada pela reação da ninidrina com aminas primárias livres após a desproteção e a cor amarela indicaria o acoplamento completo do aminoácido. (75)

Após o término da síntese é feita a clivagem da resina e remoção dos grupos protetores das cadeias laterais com uma solução ácida adequada, em nosso caso foi utilizado 
uma solução de clivagem contendo 92,5\% de TFA, 2,5\% água, 2,5\% de triisopropilsilano (TIS), 2,5\% 1,2-etanoditiol (EDT), em uma agitação branda por $2 \mathrm{~h}$. Após este procedimento o peptídeo bruto foi precipitado com éter etílico anidro gelado, separado do material nãopeptídico solúvel por centrifugação e extraído em uma solução, onde a proporção é dependente da polaridade do peptídeo, e em nosso caso foi de 0,045\% (v/v) TFA/ $\mathrm{H}_{2} \mathrm{O}$ (solvente $A$ ) e $0,036 \%(v / v)$ acetonitrila $(A C N) / \mathrm{H}_{2} \mathrm{O}$ (solvente $B$ ), e então liofilizado.

O peptídeo bruto foi então dissolvido nos solventes A e B, já mencionados acima, e purificados por meio de Cromatografia Líquida de Alta Eficiência em fase reversa (HPLC, do inglês High Performance Liquid Chromatography), utilizando um equipamento System Gold Beckman, em coluna reversa $\mathrm{C} 18$, de dimensão $1,0 \times 25 \mathrm{~cm}$, onde foi utilizado um programa gradiente, adequado para cada peptídeo, de solvente B. O material foi detectado por sua absorção no comprimento de onda de $220 \mathrm{~nm}$ e, a pureza determinada em modo analítico com um programa isocrático, com porcentagem adequada de solvente B. O conteúdo dos tubos foi reunido de acordo com o grau de pureza encontrado e, então, liofilizados. Após a liofilização dos materiais purificados, a análise de pureza de cada fração foi realizada por meio de HPLC analítica em um aparelho analítico Shimadzu, em coluna 4,6 mm x $25 \mathrm{~cm}$ de fase reversa C18, com a detecção ajustada em $220 \mathrm{~nm}$, utilizando um programa gradiente de 5 a $95 \%$ de solvente $B$ em 30 minutos com fluxo de $5 \mathrm{~mL}$ por minuto.

A identificação do peptídeo foi confirmada por espectrometria de massas em um equipamento Bruker, injeção íon trap. Esta técnica permite determinar a razão massa molecular/carga das amostras analisadas e baseia-se em uma câmera injetora que ioniza a amostra por um método chamado eletrospray, um quadrupolo simples e um detector, todos dentro de um sistema a vácuo. O espectro de massas permite assim o cálculo das massas moleculares através da equação:

$$
M M_{\text {pept }}=\frac{M M_{z}+z M M_{H^{\prime}}}{Z}
$$

onde $M M_{\text {pept }}$ é a massa molecular do peptídeo analisado, $M M_{z}$ é a massa molecular quando o peptídeo está ionizado com carga z, z é a quantidade de cargas em que está o peptídeo e $M M_{H^{\prime}}$ é a massa molecular do hidrogênio protonado, de valor $1,008 \mathrm{~g} / \mathrm{mol}$. 
Todos os equipamentos mencionados nesta seção estão localizados no Departamento de Bioquímica e Tecnologia Química no Instituto de Química da UNESP Campus Araraquara.

\subsection{Complexos metálicos}

Os complexos metálicos utilizados foram cedidos pela Prof(a) $\operatorname{Dr}(a)$. Gianella Facchin, da Universidade de La Republica do Uruguai, e são sintetizados rotineiramente por nossos colaboradores através de procedimentos que envolvem a interação de ligantes com uma solução de $\mathrm{Cu}(\mathrm{II})$, segundo protocolo descrito anteriormente nas referências. $(66,76) 0$ ligante Fenantrolina, além dos complexos ternários de Cu-dipeptídeo-Fenantrolina (Figura 8) utilizados neste trabalho são apresentados na Tabela 4.

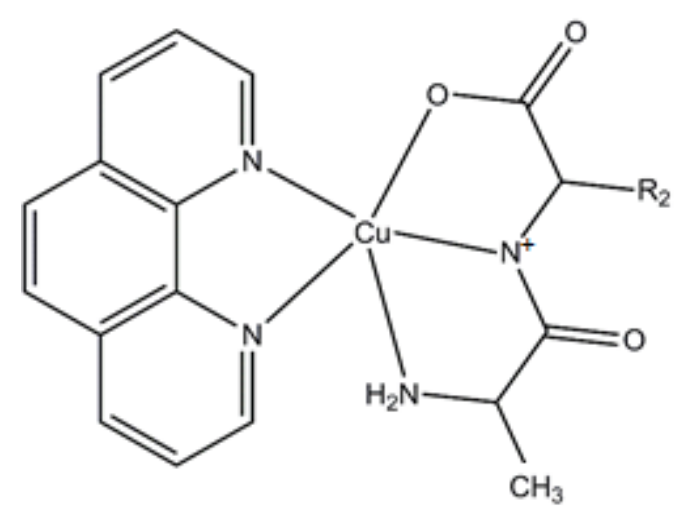

Figura 8 - Esquema do complexo de coordenação [Cu(dipeptídeo)(phen)]. Onde $R_{2}=H$ para L-Ala-Gly e $\mathbf{R}_{2}=\mathrm{CH}_{2}$-phenyl para L-Ala-Phe. Figura adaptada de (66). 
Tabela 4 - Compostos metálicos estudados neste trabalho. Tabela elaborada pela autora.

\begin{tabular}{cc}
\hline Composto & Sigla \\
\hline 1,10-Fenantrolina & Phen \\
\hline$\left[\mathrm{Cu}_{2} \mathrm{Cl}_{4}(\text { phen })_{2}\right]$ & $\mathrm{Cu}($ phen $)$ \\
\hline$\left[\mathrm{Cu}(\right.$ Ala-Gly)(phen) $) \cdot 5 \mathrm{H}_{2} \mathrm{O}$ & $\mathrm{Cu}(\mathrm{AG})($ phen) \\
\hline$\left[\mathrm{Cu}(\right.$ Ala-Phe)(phen) $) \cdot 4 \mathrm{H}_{2} \mathrm{O}$ & $\mathrm{Cu}(\mathrm{AF})$ (phen) \\
\hline
\end{tabular}

\subsection{Dicroísmo circular}

O sinal de dicroísmo circular ( $C D$, do inglês circular dichroism) é a diferença na absorção da luz polarizada circularmente à direita e à esquerda, e é medido em função de diferentes comprimentos de onda. O espetro de CD na região ultravioleta é frequentemente utilizado para se determinar o conteúdo de estrutura secundária de peptídeos e proteínas em solução, que podem conter estruturas em $\alpha$-hélice, folha- $\beta$ e desestruturadas, onde cada um tem um perfil de espectro diferenciado, como podemos observar na Figura 9.

Essa técnica espectroscópica é usada em estudos de moléculas quirais de todos os tipos, porém sua aplicação mais importante é no estudo de moléculas biológicas, devido à sua sensibilidade às mudanças conformacionais das biomoléculas, que não são percebidas facilmente com outras técnicas. (77) A absorção na região abaixo de $240 \mathrm{~nm}$ é devida, principalmente, às ligações peptídicas, nos possibilitando assim a caracterização do tipo de estrutura secundária formada pelo peptídeo. (78) 


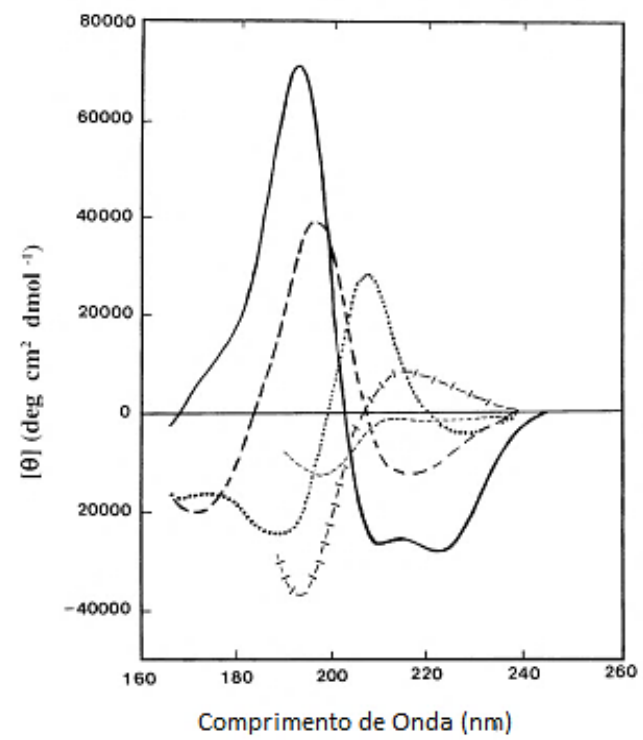

Figura 9 - Espectro de CD associado a região UV distante com os diversos tipos de estruturas secundárias. Linha sólida, $\alpha$-hélice; linha tracejado longo, folha- $\beta$ anti-paralela; linha pontilhada, volta- $\beta$ tipo I; linha pontilhada cruzada, 3-1-hélice estendida ou poli (Pro) II hélice; linha pontilhado curto, estrutura irregular. Figura adaptada de (78).

Os espectros de CD foram medidos no intervalo de comprimento de onda de 190 a $260 \mathrm{~nm}$ em um espectropolarímetro Jasco J720 ou J815, ambos situados no grupo de Biofísica Molecular "Sérgio Mascarenhas", no Instituto de Física de São Carlos (IFSC) - USP. Todas as medidas foram realizadas à temperatura ambiente, com passo de 0,1 nm, velocidade de $50 \mathrm{~nm} / \mathrm{min}$, largura de banda de $2 \mathrm{~nm}, 8 \mathrm{~s}$ de resposta e $100 \mathrm{mdeg}$ de sensibilidade. Os espectros são retirados da média de, no mínimo, 6 varreduras independentes; as contribuições do tampão foram subtraídas e os espectros normalizados com relação à concentração, ao comprimento da cubeta e ao número de ligações peptídicas de cada peptídeo, ou seja, estão em elipticidade molar por resíduo. O tratamento dos dados foi realizado pelo software CDTool (79) (80). A concentração de peptídeo foi de $1 \mathrm{mg} / \mathrm{mL}$ em solução tampão, em pHs 5 ou 7,4, ou na presença de vesículas de POPC/POPG na razão L/P de 45. Além dos testes realizados com concentrações diferentes de TFE (2,2,2Trifluoroethanol), adicionados aos peptídeos em solução, para a investigação do potencial dos peptídeos se estruturarem. 


\subsection{Fluorescência}

Os experimentos de fluorescência foram realizados em um espectrofluorímetro ISS K2, modo estático, que possui um agitador magnético na cela da cubeta e está equipado com um sistema de controle de temperatura Neslab RTE-210, situado no grupo de Biofísica Molecular "Sérgio Mascarenhas", no Instituto de Física de São Carlos (IFSC) - USP. Foram utilizadas fendas de emissão e excitação de 0,5 e $1 \mathrm{~nm}$, respectivamente, e todos os experimentos foram realizados à temperatura ambiente e em triplicatas.

\subsubsection{Mistura lipídica}

A fusão de membranas é um processo essencial para a infecção viral da Dengue, pois representa o mecanismo de entrada do vírus na célula hospedeira, sendo, assim, de grande importância estudarmos tal evento. A metodologia de Transferência de Energia por Ressonância Förster (FRET, do inglês Förster resonance energy transfer) é normalmente utilizada para monitorar a dinâmica e as interações em nível molecular. Esse mecanismo ocorre quando uma molécula de um fluoróforo doador, no seu estado excitado, transfere energia não-radiativamente a uma molécula de um fluoróforo receptor, em seu estado fundamental. Quando estes dois fluoróforos estão muito próximos (entre 10 a $100 \AA ̊$ ), no nosso caso, juntos na mesma vesícula, a fluorescência do doador é suprimida pelo receptor; ou seja, para o FRET ocorrer é necessário que haja uma "sobreposição" entre a banda de emissão da molécula doadora e a de excitação da molécula aceitadora. (81)

Como esse processo é dependente da separação espacial entre as sondas, Struck et al. desenvolveram um ensaio conveniente, baseado no FRET entre as sondas fluorescentes N-NBD-PE e N-Rh-PE para o monitoramento da mistura lipídica durante a fusão de membranas, que ainda é um dos ensaios mais populares empregados atualmente. Os estudos mostram que as mudanças observadas na intensidade de fluorescência entre esses fluoróforos indicam apenas eventos de fusão e não estão relacionadas com outros efeitos, como troca de lipídios, por exemplo. (82) 
Em uma população de lipossomos sob excitação, contendo ambas as sondas fluorescentes, em concentrações adequadas, tal que os fluoróforos individuais estão dentro do raio Förster, ocorre a transferência de energia do doador para o receptor e este fluoresce como se estivesse sendo diretamente excitado. Após a diluição, a distância entre as sondas aumenta, o que resulta em um FRET menor, com o aumento na fluorescência do doador, como vemos na Figura 10. Por razões de sensibilidade, é geralmente monitorada a mudança na fluorescência do doador para os ensaios de fusão.

Neste trabalho utilizamos LUVs de POPC/POPG (4/1, mol/mol) dopadas com $1 \%$ de NBD-PE e 1\% de Rh-PE e vesículas da mesma composição não-marcadas, na proporção molar 1/9, respectivamente. Em seguida, foram adicionadas diferentes concentrações dos peptídeos em estudo para o monitoramos da cinética de fusão. As amostras são excitadas em $467 \mathrm{~nm}$, com emissão em $530 \mathrm{~nm}$, emissão do doador. A porcentagem de mistura lipídica foi calculada pela Equação 1:

$$
\% \text { mistura lipídica }=100 \times \frac{I-I_{0}}{I_{100}-I_{0}}
$$

onde $I_{0}$ e $I_{100}$ correspondem à intensidade de fluorescência das vesículas antes da adição do peptídeo e após a adição de 1\% de triton x-100 (v/v), respectivamente, e $I$ é a intensidade de fluorescência em dado instante de tempo. É importante ressaltar que a mistura lipídica corresponde à hemifusão, que é um passo intermediário para a fusão total das membranas. 

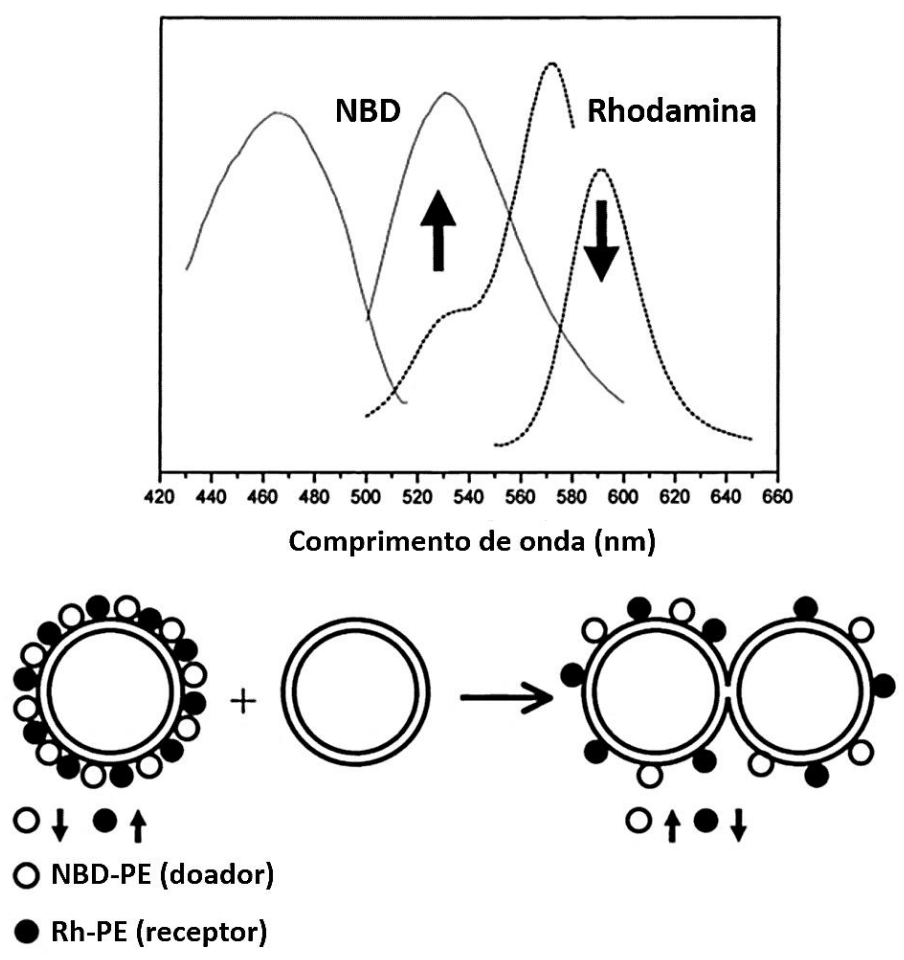

Figura 10 - Representação de um ensaio de mistura lipídica baseado em FRET. Com os fluoróforos na mesma vesícula, ocorre a transferência de energia do NBD-PE (doador) para o Rh-PE (receptor); com a fusão das vesículas, a distância entre as sondas aumenta, o que resulta em um FRET menor, com o aumento na fluorescência do NBD-PE. Figura adaptada de (83).

\subsubsection{Fluorescência do Triptofano}

A fluorescência intrínseca de proteínas e peptídeos é devida aos aminoácidos aromáticos, principalmente o triptofano (Trp), já que a emissão da tirosina (Tyr) é frequentemente suprimida e a fenilalanina (Phe) tem um rendimento quântico muito baixo (84) .

Pode-se medir seletivamente apenas a fluorescência devido a resíduos de Trp através da excitação em 295 nm, pois neste comprimento de onda não há absorção da Tyr. Em solução aquosa o Trp apresenta uma banda de fluorescência larga, com máximo em torno de $350 \mathrm{~nm}$ (podendo variar de equipamento para equipamento, com máximo entre 348-353 $\mathrm{nm}$, aproximadamente). Este resíduo é muito sensível à mobilidade e polaridade do meio, sendo o espectro de emissão deslocado para comprimentos de onda menores (blue shift) 
quando a hidrofobicidade do meio aumenta. Logo, o monitoramento da fluorescência deste resíduo possibilita estudos da dinâmica e estrutura de proteínas e peptídeos. (85)

A quantidade de peptídeo ligado à bicamada, como uma fração do total de peptídeo presente no sistema, é estimada de maneira quantitativa pelo coeficiente de partição, $K_{P}$, (86) e pode ser obtido pela Equação 2:

$$
\frac{I}{I_{0}}=1+\left[\left(\frac{I_{\text {máx }}}{I_{0}}-1\right) \times\left(\frac{K_{P}[L]}{[W]+K_{P}[L]}\right)\right]
$$

onde $I_{0}$ e $I$ representam as intensidades de fluorescência na ausência e na presença do

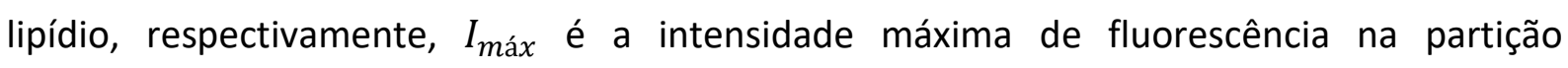
determinada pelo ajuste da equação pelos dados experimentais, $[L]$ é a concentração do lipídio, e $[W]$ é a concentração da água $\left(55,5 \mathrm{M}\right.$ a $25^{\circ} \mathrm{C}$ e $55,3 \mathrm{M}$ a $\left.37^{\circ} \mathrm{C}\right)$. É importante ressaltar que este coeficiente não contém qualquer tipo de informação topográfica sobre a localização do soluto na membrana, que pode ser adsorvido na interface ou internalizado.

Para uma melhor avaliação da acessibilidade do peptídeo ao solvente podemos realizar experimentos de supressão da fluorescência. A emissão de fluorescência do Trp pode ser suprimida por uma variedade de substâncias, como oxigênio, iodeto e acrilamida, que são supressores extrínsecos. (87) A acrilamida é um supressor neutro polar, altamente eficiente. Ela não é capaz de penetrar em grande parte no núcleo hidrofóbico da bicamada lipídica, podendo nos dar informações sobre a localização do resíduo de Trp em relação à fase aquosa.

A supressão da fluorescência ocorre devido ao contato físico, ou seja, das colisões, da acrilamida com o anel indol do Trp excitado. Uma maior supressão da fluorescência indica uma alta exposição do resíduo ao solvente, logo uma menor inserção na bicamada. A razão entre as intensidades na ausência $\left(I_{0}\right)$ e na presença $(I)$ do supressor à concentração $[Q]$ é usada para determinar a constante de Stern-Volmer, $K_{S V}$, mostrada na Equação 3 :

$$
\frac{I_{0}}{I}=1+K_{S V}[Q]
$$

Para um resíduo de Trp totalmente exposto ao solvente a acrilamida apresenta um alto valor de $K_{S V}$, da ordem de $25 \mathrm{M}^{-1}$. (84) 
É importante ressaltar que nem a distância nos experimentos de FRET, nem a taxa de supressão ou coeficiente de partição, são medidos diretamente nos experimentos de fluorescência, todos são parâmetros derivados das medidas das intensidades.

Em nosso trabalho, a partição dos peptídeos nas membranas foi monitorada através da mudança da fluorescência do Trp através de titulações de pequenos volumes de LUVs de POPC/POPG na amostra contendo os peptídeos. Nos ensaios de supressão, alíquotas de uma solução $4 \mathrm{M}$ de acrilamida foram tituladas em uma solução contendo os peptídeos em estudo, na ausência e na presença de vesículas de POPC/POPG (4/1) na razão molar L/P de $45 / 1$

Em ambos os experimentos, as medidas foram realizadas excitando-se a amostra em 280 nm e observando a emissão entre 300 e 450 nm, utilizando um filtro cutoff em 295 nm, com passos de $1 \mathrm{~nm}$. Os resultados obtidos foram corrigidos pela diluição e pela contribuição de espalhamento das vesículas

\subsection{Calorimetria Diferencial de Varredura}

A calorimetria diferencial de varredura (DSC, do inglês differential scanning calorimetry) é a técnica mais utilizada para estudos de efeitos térmicos em diversos materiais, incluindo sistemas biologicamente relevantes. Ela mede diretamente as mudanças de calor que ocorrem em biomoléculas durante uma variação controlada de temperatura e, com isso, é possível se determinar dados termodinâmicos absolutos para transições termicamente induzidas. (88)

O princípio de funcionamento do DSC é a comparação simultânea do calor recebido pela amostra, no nosso caso, a suspensão lipídica, com o da referência inerte, que não sofre transição de fase em função da variação de temperatura. Nesta técnica, a amostra e a referência são aquecidas simultaneamente de maneira controlada, tal que as celas são mantidas à mesma temperatura. Quando há uma transição de fase na amostra, há uma diferença no calor fornecido entre as duas celas. Essa diferença, à pressão constante, é então monitorada e convertida, nos dando a capacidade calorifica em função da 
temperatura. Logo, o resultado obtido do DSC é uma medida da energia transferida para a amostra.

Em um único experimento pode-se obter o ponto de transição média $\left(T_{M}\right)$, a entalpia e a mudança na capacidade calorífica, que à pressão constante, pode ser definida por:

$$
C_{P}=(\partial q / \partial T)_{P}
$$

onde $T$ é a temperatura e $q$ é o calor absorvido à pressão constante. Se a temperatura varia de $T_{i}$ a $T_{f}$ a entalpia calorimétrica da reação é:

$$
\Delta H_{C A L}=\int_{T_{i}}^{T_{f}} C_{P}(T) d T
$$

Através destes valores, a entropia da transição de fase pode ser determinada como:

$$
\Delta S=\frac{\Delta H_{C A L}}{T_{M}}
$$

As comparações entre esses parâmetros nos dão os efeitos das modificações estruturais na termodinâmica das transições de fase. Outro parâmetro importante que podemos determinar através do termograma é a largura à meia altura da transição de fase, $\Delta T_{1 / 2}$, que está relacionada ao grau de cooperatividade do processo experimentado pelas moléculas na amostra. Quanto menor esta largura, maior será a cooperatividade nesse processo termodinâmico. (89)

Na Figura 11, temos um termograma que ilustra o pico característico de uma mudança de fase. A diferença na linha de base, antes e depois dessa transição, reflete a diferença das capacidades caloríficas das duas fases.

Os efeitos dos peptídeos e complexos, estudados nesta tese, nas transições de fase dos lipossomos foram observados utilizando um microcalorímetro VP-DSC da empresa MicroCal, situado no grupo de Biofísica Molecular "Sérgio Mascarenhas", no IFSC - USP. Foi escolhida uma taxa de fornecimento de calor de $20{ }^{\circ} \mathrm{C}$ por hora em um intervalo de temperatura de $25{ }^{\circ} \mathrm{C}$ a $50{ }^{\circ} \mathrm{C}$ e os termogramas foram registrados apenas durante $\mathrm{O}$ aquecimento das amostras.

Para garantirmos a reprodutibilidade dos termogramas, antes de cada medida as amostras foram mantidas em equilíbrio térmico a $50{ }^{\circ} \mathrm{C}$ durante, aproximadamente, 15 
minutos e um número suficiente de termogramas foi registrado até haver a reprodutibilidade entre os mesmos.

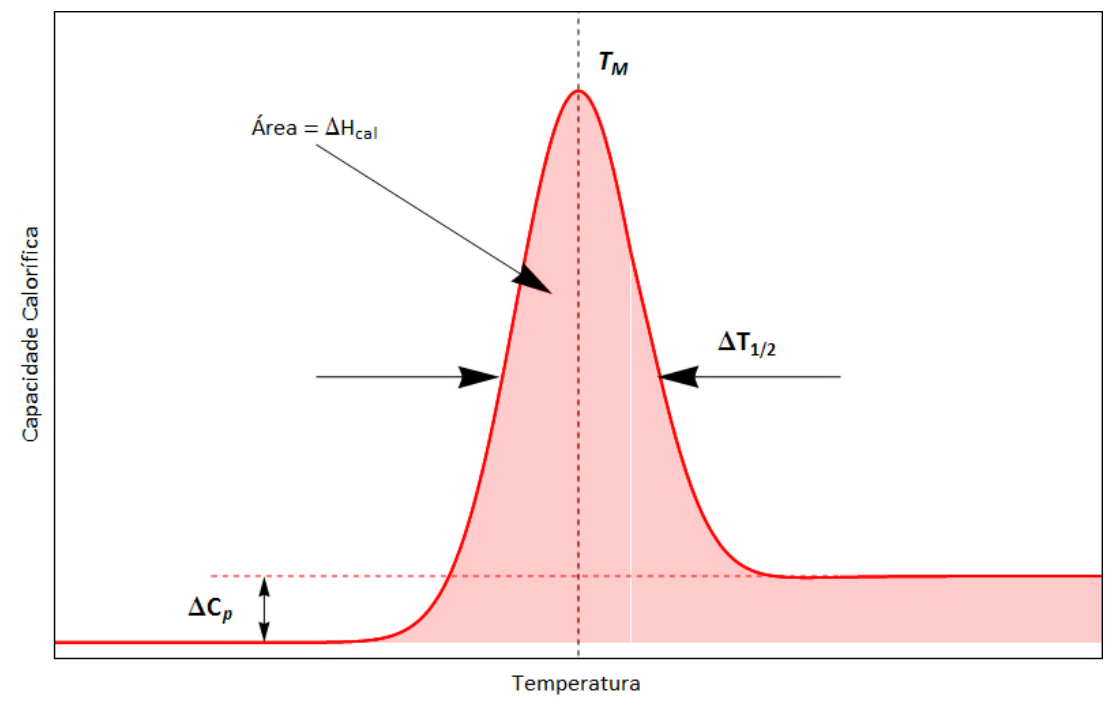

Figura 11 - Esquema representativo de um termograma. A diferença na capacidade calorífica, $\Delta C_{p}$, do evento térmico é caracterizada pela temperatura de transição de fase $T_{M}$, onde a capacidade calorifica atinge um máximo. A entalpia calorimétrica, $\Delta \mathrm{H}_{\mathrm{CAL}}$, é a área sob a curva, que é dependente com a temperatura da capacidade calorífica da amostra à pressão constante. Figura elaborada pela autora.

O tratamento e análise dos dados, como a subtração e correção da linha de base e integração dos picos calorimétricos, foram realizados usando-se o software fornecido pela MicroCal, desenvolvido dentro do pacote Origin 7.0.

\subsection{Ressonância Paramagnética Eletrônica (RPE)}

A Ressonância Paramagnética Eletrônica (RPE; comumente denominado EPR, do inglês electron paramagnetic resonance ou ESR, de electron spin resonance) é uma espectroscopia que detecta espécies que contém elétrons desemparelhados, como íons metálicos, radicais orgânicos e antioxidantes. Esta técnica vem sendo utilizada para caracterizar as interações desses tipos de moléculas com o ambiente ao seu redor. Além de contribuir no estudo da estrutura e dinâmica molecular de sistemas biológicos relevantes, caracterizando as espécies paramagnéticas intrinsicamente presentes, como centros 
metálicos ou extrinsecamente introduzidas, como marcadores de spin ligados covalentemente. É uma técnica altamente sensível e não está limitada pelo tamanho da molécula estudada, nem por suas propriedades óticas.

Esta técnica se baseia na aplicação de um campo magnético estático no qual os níveis de energia do momento magnético associado ao spin eletrônico se desdobram. Para que haja transição entre estes níveis deve ser feita a excitação da amostra com radiação de frequência tal que seja obedecida a condição de ressonância,

$$
h v=g \beta H=\Delta E
$$

onde $h$ é a constante de Planck, $v$ é a frequência da radiação eletromagnética, $H$ é o campo magnético, $\beta$ é o magnéton de Bohr e $g$, uma constante de proporcionalidade, cujo valor depende das espécies magnéticas em consideração.

\subsubsection{Marcadores de spin}

A maioria dos materiais químicos e biológicos não possuem um elétron desemparelhado, ou seja, não são paramagnéticos, não produzindo assim um sinal de RPE. Em 1965, foi proposta uma alternativa para se estudar estes materiais, através do método de marcador de spin. Esses marcadores podem, a princípio, ser qualquer molécula paramagnética, porém o mais utilizado são os do tipo nitróxido, que são radicais livres estáveis. (90)

Uma das vantagens é que este fragmento $\mathrm{N}-\mathrm{O}$ pode ser introduzido em moléculas orgânicas maiores, ficando estáveis em temperatura e pH fisiológicos, possibilitando uma gama de estudos biológicos. Como estamos interessados no estudo de interações de pequenas moléculas com modelos de membranas, é comum se utilizar o radical N-O ligado a fosfolipídios. Como essas sondas são muito sensíveis ao ambiente em que estão inseridos, nos possibilita monitorar a estrutura dinâmica do ambiente lipídico no seu entorno. 0 ordenamento e a dinâmica do marcador, no sistema de interesse, refletem contribuições tanto da estrutura molecular em torno do centro paramagnético quanto da fluidez desse microambiente. (91) 
Obtidos os espectros, duas metodologias são utilizadas para a análise dos dados experimentais: a análise convencional, baseada na definição de alguns parâmetros empíricos sobre os próprios espectros e a utilização de simulações espectrais. $(92,93)$ Neste trabalho utilizamos apenas a análise dos parâmetros empíricos, que são definidos sobre o próprio espectro de RPE e nos fornecem informações importantes sobre a dinâmica e a estrutura do marcador de spin na membrana.

Os parâmetros a serem utilizados na análise depende da localização da sonda na bicamada lipídica e são apresentados na Figura 12. Os espectros do radical nitróxido apresentam três picos, que representam as linhas de campo baixo $\left(h_{+1}\right)$, central $\left(h_{0}\right)$ e alto $\left(h_{-1}\right)$, onde os índices se originam do número quântico associado ao estado de spin nuclear do nitrogênio, que caracteriza cada uma das ressonâncias oriundas do desemparelhamento dos spins. A largura relativa dessas linhas depende da velocidade de tombamento da sonda, que são estreitas para movimentos rápidos, em sondas com maior mobilidade, próximas ao meio da bicamada ou na cabeça polar do fosfolipídio; e se alargam à medida que o movimento se torna mais lento, para sondas localizadas em meios que oferecem maior impedimento ao movimento, ou seja, no início da cadeia carbônica do fosfolipídio.

Para sondas localizadas em regiões com maior fluidez, os melhores parâmetros para a análise empírica são as razões entre as amplitudes das linhas de campo, $h_{+1} / h_{0}$ e $h_{-1} / h_{0}$. Com o aumento da temperatura a linha de campo alto se estreita mais do que a de campo baixo, fazendo com que seja mais sensível para análises acima da temperatura de transição. Já para marcadores de spin com movimentos mais restritos, o melhor parâmetro para a análise é o desdobramento hiperfino máximo, $A_{M A ́ X}$, que aumenta com o empacotamento do meio. 

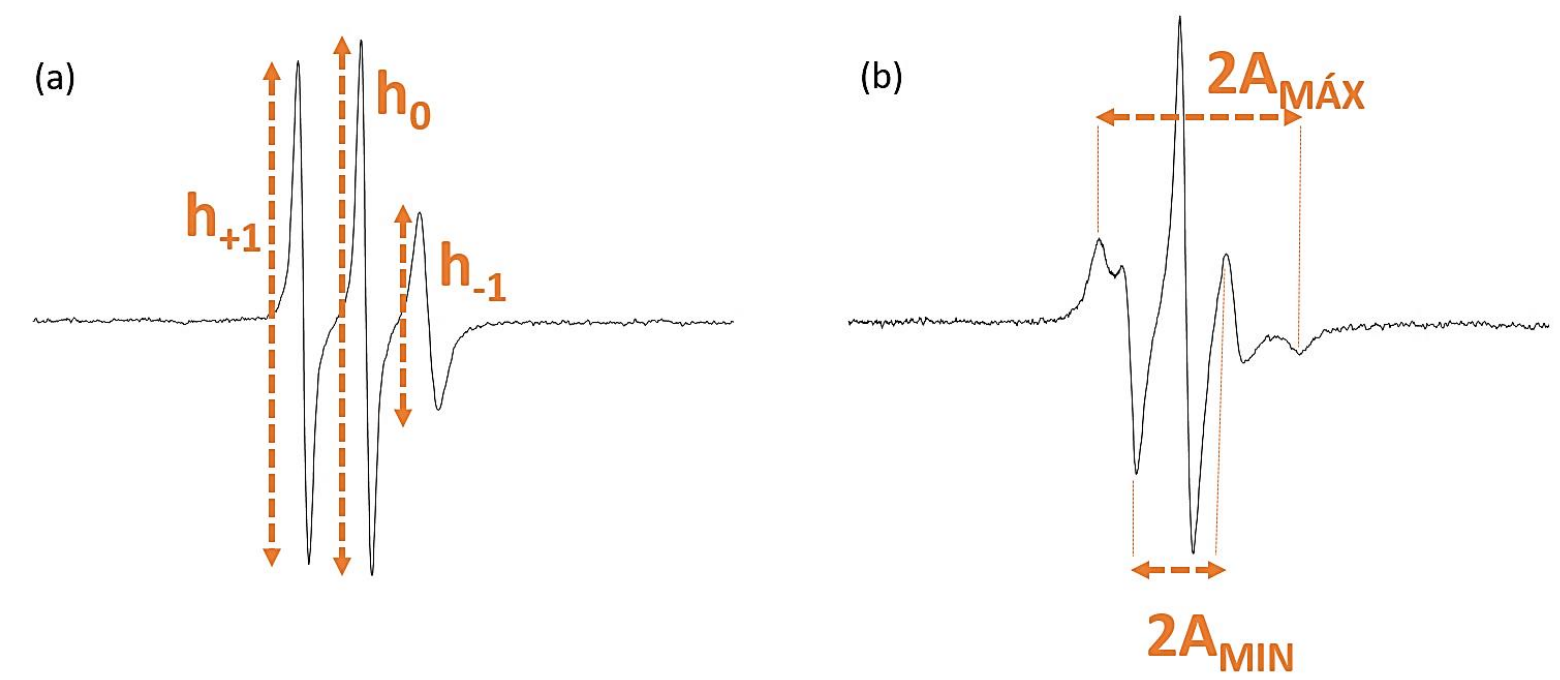

Figura 12 - Definições dos parâmetros empíricos utilizados para a análise dos espectros de RPE para o radical nitróxido em membranas, no regime (a) mais rápido e (b) mais lento. Figura elaborada pela autora.

\subsubsection{Marcação de spin sítio-dirigida}

Proteínas, peptídeos e ácidos nucleicos não possuem elétrons desemparelhados, logo para conseguirmos estudar esses tipos de moléculas podemos fazer uso da marcação de spin sítio-dirigida (SDSL, do inglês site-directed spin labeling). A técnica consiste em ligar covalentemente uma cadeia lateral, por exemplo, com um marcador de spin a um sítio específico de uma proteína ou peptídeo. (94)

O marcador mais comumente utilizado é o MTSSL. Esta molécula reage com resíduos de cisteína, uma vez que é a única cadeia lateral de aminoácido que contém um grupo sulfidrila (-SH). Como o método SDSL requer uma única cisteína (Cys) na sequência para a reação, para que não ocorra a formação de pontes dissulfeto e com isso não haja acessibilidade da sonda ao grupo - $\mathrm{SH}$, é necessário que todas as outras cisteínas da sequência, que não serão marcadas com o MTSSL, sejam trocadas por outros resíduos.

Neste trabalho, substituímos a cisteína nativa da sequência do peptídeo de interesse por um resíduo de serina (Ser), por apresentarem estrutura e polaridade semelhante, como realizado anteriormente por Cespedes e Stauffer. $(95,96)$ A reação da ligação da sonda de spin à cadeia lateral do resíduo de Cys é apresentada na Figura 13, onde o protocolo que foi 
seguido requer um excesso de 5 vezes do marcador em relação à quantidade de peptídeo purificado, em uma solução tampão Tris- $\mathrm{HCl} 10 \mathrm{mM}$ e $\mathrm{NaCl} 10 \mathrm{mM}$, em pH 7, por 4 h. É importante ressaltar que se deve adicionar o MTSSL imediatamente após a solubilização do peptídeo, para evitar a formação de dímeros. A reação deve ser protegida da luz, feita sob agitação e à temperatura ambiente por $4 \mathrm{~h}$. Após este processo, o peptídeo é novamente purificado, obtendo-se assim a fração pura do peptídeo marcado.

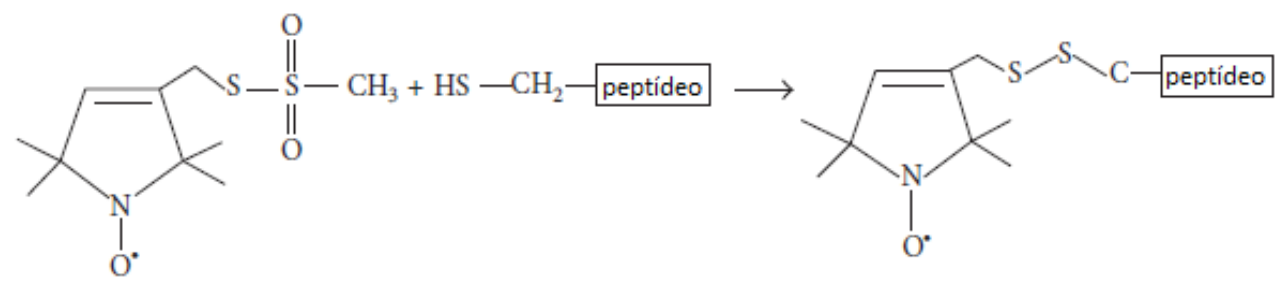

Figura 13 - Reação da ligação do marcador de spin MTSSL às cadeias laterais da cisteína. Figura adaptada de (97).

\subsubsection{Medidas de RPE}

As medidas de RPE foram realizadas no espectrômetro Varian E109, situado no grupo de Biofísica Molecular "Sérgio Mascarenhas", no Instituto de Física de São Carlos (IFSC) USP. O equipamento opera em banda $X(9,4 \mathrm{GHz})$, no modo de onda contínua (CW) e possui controlador de temperatura acoplado.

As amostras, todas em solução, foram transferidas para tubos capilares da marca Satelit, com diâmetro de 1,5 mm e volume de $50 \mu \mathrm{L}$, para garantir a concentração da dispersão lipídica em uma de suas extremidades e aumentar a relação sinal-ruído das amostras nas medidas.

Os parâmetros de operação do equipamento comuns a todas as amostras foram: varredura do campo magnético de $160 \mathrm{G}$, frequência de modulação de $100 \mathrm{kHz}$, constante de tempo de 0,064 s, amplitude de modulação do campo de $1 \mathrm{G}$, tempo de varredura de $60 \mathrm{~s}$, potência de microondas entre 10 e $20 \mathrm{~mW}$. 
O capilar com a amostra foi colocado em um tubo de quartzo contendo um banho de óleo mineral comercial, para garantir a estabilização da temperatura dentro do capilar e aumentar a confiabilidade das medidas, e posicionado no centro da cavidade ressonante.

Para as medidas com vesículas de POPC/POPG foi mantida a temperatura a $25^{\circ} \mathrm{C}$ e para as medidas com DPPC e DPPG, houve variação da temperatura no intervalo ente 20 a $50^{\circ} \mathrm{C}$.

Para a análise dos espectros obtidos foi utilizada , a análise convencional, baseada na definição de parâmetros empíricos, que já foram mencionadas na seção 3.7.1.

\subsection{Espalhamento de Luz Dinâmica (DLS)}

O espalhamento de luz dinâmica (DLS, do inglês dynamic light scattering), também conhecido como Espectroscopia de Correlação de Fótons (PCS, do inglês photon correlation spectroscopy), é amplamente utilizado para a avaliação sobre o tamanho de partículas ou moléculas em suspensão. O espalhamento da luz é uma consequência da interação da luz com o campo elétrico de uma partícula pequena.

A técnica consiste na análise das flutuações de intensidade da luz espalhada em um determinado ângulo. Mede a velocidade de partículas em movimento aleatório (Browniano) devido ao bombardeamento pelas moléculas de solvente do meio. (98) A relação entre a velocidade devido ao movimento Browniano, coeficiente de difusão (D), e o tamanho das partículas em dispersão pode ser definida pela equação de Stokes-Einstein: $(99,100)$

$$
d_{H}=\frac{k T}{3 \pi \eta D}
$$

onde diâmetro $d_{H}$ é o diâmetro hidrodinâmico, que é o diâmetro de uma esfera dura que difunde à mesma velocidade que a partícula sendo medida, $\mathrm{k}$ é a constante de Boltzmann $\left(1,38 \times 10^{-23} \mathrm{~J} \cdot \mathrm{K}^{-1}\right), \mathrm{T}$ a temperatura e $\eta$ a viscosidade do meio.

Os experimentos foram realizados no equipamento Zetasizer $\mu \mathrm{V}$ da Malvern Instruments localizado no grupo de Biofísica Molecular "Sérgio Mascarenhas", no Instituto de Física de São Carlos (IFSC) - USP. As medidas foram feitas à temperatura ambiente, para 
avaliar a influência dos peptídeos de fusão no tamanho das vesículas puras de POPC/POPG em duas proporções L/P, 200 e 45.

\subsection{Simulação computacional de Dinâmica Molecular}

A interação entre os peptídeos virais e as bicamadas lipídicas foi investigada através da técnica de simulação computacional de Dinâmica Molecular (DM), realizadas em colaboração pelo Dr. Danilo da Silva Olivier, do Instituto de Biociências, Letras e Ciências Exatas de São José do Rio Preto da Universidade Estadual Paulista Júlio de Mesquita Filho (IBILCE/UNESP). Estudamos o peptídeo putativo de fusão (PFDEN) e os peptídeos com as regiões flanqueadoras dos sorotipos 1 e 3, DENV-1 e DENV-3, nativos e mutados com a serina.

As sequências primárias dos peptídeos foram retiradas de dois arquivos disponíveis no Protein Data Bank (PDB) e que correspondiam à glicoproteína do vírus da Dengue do sorotipo 1 (PDB: 3G7T) e sorotipo 3 (PDB: 1UZG). Duas modificações foram realizadas nos peptídeos: o estado de protonação das histidinas foi modificado de modo a mimetizar o pH do meio onde o vírus é ativo, pH 5, e a segunda mudança foi a mutação das cisteínas por serinas, eliminando as pontes dissulfetos e gerando os peptídeos DENV-1S e 3S. Os peptídeos DENV-1C e 3C foram obtidos diretamente dos PDB's e o peptídeo de fusão foi obtido a partir da sequência que se mantém em todas as glicoproteínas dos vírus da Dengue.

A bicamada lipídica utilizada, foi uma mistura entre POPC e POPG na proporção de 4/1, visando a mimetização dos experimentos de bancada. A bicamada lipídica mista foi construída contendo 80 lipídios de POPC e 20 lipídios de POPG por monocamada, totalizando 200 lipídios na membrana. Assim, a bicamada contém uma carga negativa total de -40. Para cada lipídio foram adicionadas 36 moléculas de água e íons de sódio ( $\mathrm{Na}$ ) para neutralização do sistema. Os critérios para avaliação da estabilidade da membrana foram: área por cabeça lipídica, parâmetro de ordem e densidade eletrônica conforme proposto por Porasso e Cascales (101). 
Um total de cinco sistemas foram construídos utilizando os peptídeos citados anteriormente em conjunto com a bicamada lipídica de POPC/POPG (4/1). Em todas as simulações foram utilizadas a razão L/P de 200/1. Na Tabela 5 representamos as informações relativas à composição dos sistemas simulados.

Tabela 5 - Composição dos sistemas simulados. Tabela elaborada pela autora.

\begin{tabular}{|ccccc|}
\hline Sistema & Designação & Átomos & $\begin{array}{c}\text { Carga } \\
\text { Peptídeo }\end{array}$ & Íons Na \\
\hline POPC/POPG+PFDEN & FP & 48260 & 1 & 39 \\
\hline POPC/POPG +DENV-1C & $1 C$ & 48307 & 5 & 35 \\
\hline POPC/POPG + DENV-1S & $1 S$ & 48584 & 5 & 35 \\
\hline POPC/POPG+DENV-3C & $3 C$ & 48583 & 3 & 37 \\
\hline POPC/POPG+DENV-3S & $3 S$ & 48581 & 3 & 37 \\
\hline
\end{tabular}

As simulações por DM foram realizadas com o pacote computacional NAMD (102) em conjunto com o campo de força CHARMM 36. $(103,104)$ O ensemble NPT (temperatura de 298 K, e pressão de 1 bar) foi aplicado aos sistemas. Os banhos de Nosé-Hoover e Langevin foram aplicados para o controle da pressão e temperatura, respectivamente. As interações eletrostáticas entre átomos não ligados foram tratadas pelo método de Particle-Mesh Ewald (PME) e truncadas em $12 \AA$, com decaimento a partir de $10 \AA$. . A etapa de minimização de energia foi aplicada aos sistemas para eliminação dos maus contatos e, posteriormente, a dinâmica foi realizada em 400 ns, com passo de integração de 2 fs. As simulações foram analisadas com o pacote de ferramentas LOOS.V.2.2.5 e o programa de visualização e análise de sistemas moleculares VMD. (105) 


\section{Resultados}

Nesta seção, são apresentados os resultados obtidos a partir dos estudos da interação com miméticos de membranas e os dois grupos de interesse desta tese: peptídeos de fusão da Dengue e complexos ternários de cobre, Fenantrolina e dipeptídeos.

\subsection{Peptídeos de fusão da Dengue}

Aqui apresentamos os resultados experimentais obtidos a partir dos ensaios com o peptídeo de fusão e as sequências com as regiões flanqueadoras dos sorotipos 1 e 3 do vírus da Dengue. São discutidos os efeitos dos peptídeos nos miméticos de membrana e as possíveis mudanças nos peptídeos através dos estudos das sequências marcadas com as sondas paramagnéticas. Além disso, são feitas comparações entre os resultados experimentais e os das simulações de dinâmica molecular.

\subsubsection{Capacidade de mistura lipídica}

Para os testes de capacidade de fusão das vesículas induzida pelos peptídeos em estudo foram realizados experimentos de FRET, como já mencionado anteriormente. A escolha da composição das vesículas, POPC/POPG (4/1), foi guiada pelos estudos de Stauffer, que demonstraram que o peptídeo de fusão da Dengue é hábil em induzir fusão em vesículas compostas pelo fosfolipídio aniônico POPG e foram corroborados pelos estudos de Olivier. $(96,106)$ Além disso, ensaios realizados reportaram que a fusão do vírus da Dengue com a membrana do hospedeiro é dependente da composição lipídica do endossoma, independente de colesterol e fortemente promovida em células de insetos, que são ricas em lipídios aniônicos. (107-109). 
Em nosso caso, os ensaios foram realizados em dois valores de $\mathrm{pH}$ diferentes, do

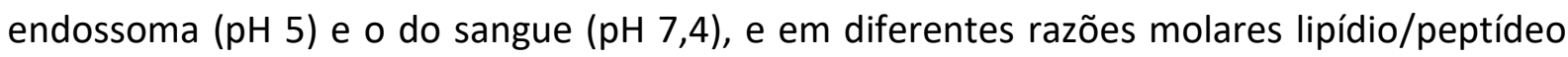
(L/P). Os resultados obtidos estão apresentados nas Figura 14 e Figura 15, para os peptídeos de fusão da dengue, sorotipo 1 e 3, contendo cisteína, com a formação da ponte dissulfeto entre elas e seus análogos contendo serina.

Como era esperado a mistura lipídica é maior em $\mathrm{pH}$ mais ácido. $\mathrm{E}$ os resultados obtidos estão de acordo com os estudos de Cespedes (95), sendo maior para o sorotipo 1 do que para o sorotipo 3. Em pH 5, para o DENV-1 há uma maior mistura lipídica para o DENV1C, o que acreditamos ser pelo fato da sequência ser mais próxima da nativa presente na proteína de fusão do vírus. Já para o DENV-3 não foi observada nenhuma mudança entre as sequências com e sem a ponte dissulfeto, o que supomos ser pelo fato da mistura lipídica ser baixa, então não conseguimos observar uma diferença significativa entre os resultados obtidos, já que os valores se encontram dentro do erro experimental.

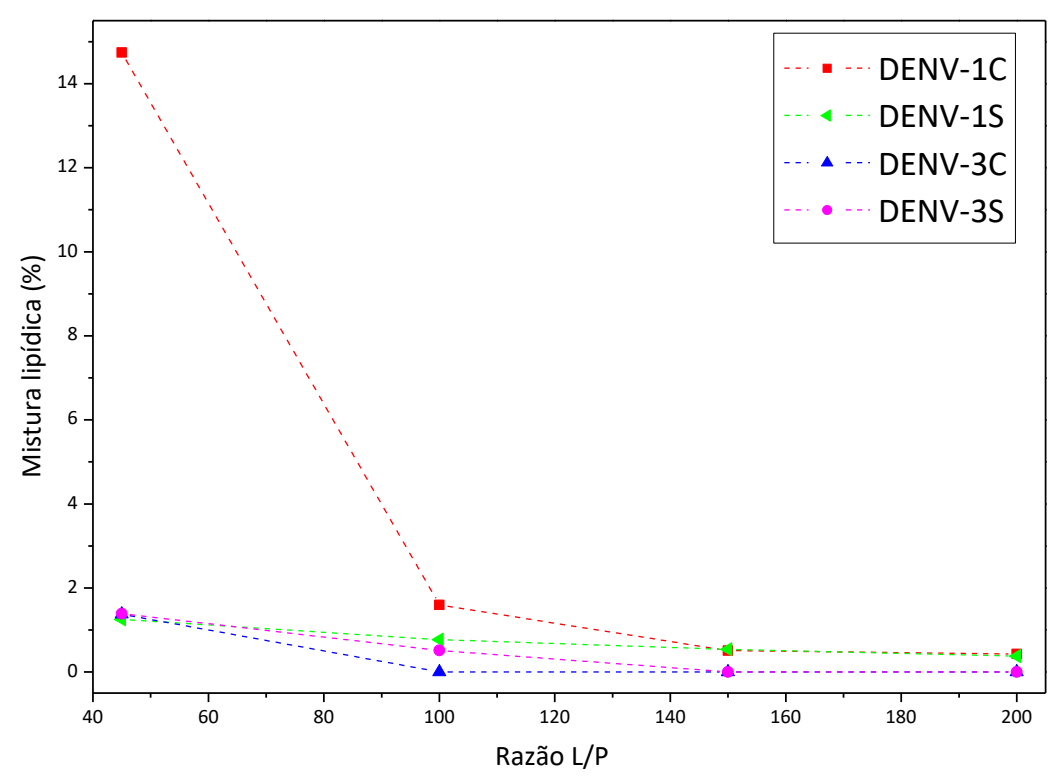

Figura 14 - Porcentagem da mistura lipídica promovida pelos peptídeos de fusão da dengue em pH 5, em diversas razões molares lipídio/peptídeo $(45,100,150,200)$. As razões máxima e mínima foram escolhidas pois são as razões L/P críticas, onde abaixo disso não há mistura lipídica detectada e acima da razão máxima há uma maior agregação dos peptídeos, impossibilitando diferenciar este evento da mistura lipídica. Figura elaborada pela autora. 
No pH 7,4, observamos uma baixa fusão das membranas, sendo que para os análogos contendo as serinas (sem ponte dissulfeto) não conseguimos detectar nenhuma mistura lipídica, como vemos na Tabela 6.

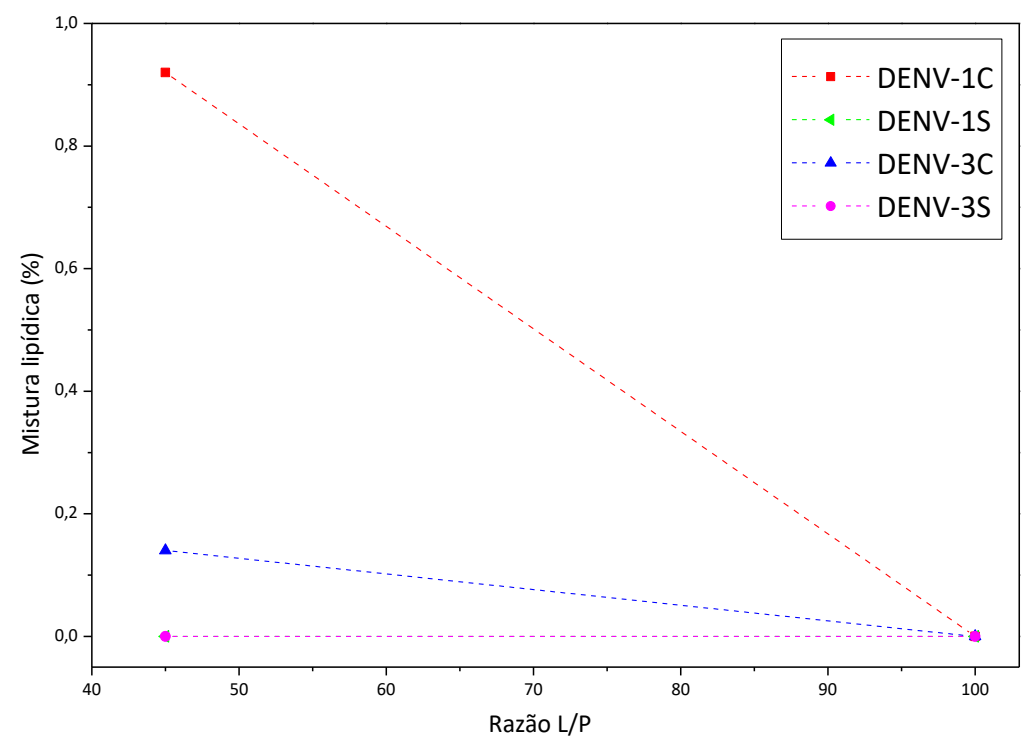

Figura 15 - Porcentagem da mistura lipídica promovida pelos peptídeos de fusão da dengue em pH 7,4, nas razões molares L/P 45 e 100. Não conseguimos detectar mistura lipídica com concentrações menores de peptídeo. Figura elaborada pela autora.

Segundo Torres e Bong (110), a estrutura secundária de um peptídeo está relacionada à sua atividade de partição na membrana, logo para um peptídeo enovelado é energeticamente mais favorável se inserir na membrana que um desestruturado, como é o caso dos peptídeos em estudo, como será mostrado na seção seguinte através dos experimentos de $C D$, podendo a baixa estruturação contribuir para a baixa mistura lipídica que obtivemos. Torres e Bong também afirmam que a habilidade de um peptídeo em induzir uma mistura lipídica não depende somente do comprimento da sequência, mas também da carga total, da polaridade e da presença de resíduos de glicina, sendo estes os requisitos responsáveis pela infecção viral, apresentando papel central na fusão da membrana com o envelope do vírus, logo esperamos a maior fusão para o sorotipo 1, que apresenta uma carga maior em pH 5 do que a sequência do sorotipo 3, como podemos ver na Tabela 7. 
Tabela 6 - Porcentagem de mistura lipídica máxima, razão L/P de 45, nos pHs 5 e 7,4 promovida pelos análogos dos peptídeos de fusão da dengue sorotipos 1 e 3 . Tabela elaborada pela autora.

\begin{tabular}{|ccc|}
\hline Peptídeos & $\begin{array}{c}\text { \% mistura lipídica } \\
\text { máxima em pH 5 }\end{array}$ & $\begin{array}{c}\text { \% mistura lipídica } \\
\text { máxima em pH 7,4 }\end{array}$ \\
\hline DENV-1C & 14,7 & 0,9 \\
\hline DENV-1S & 1,3 & $0^{*}$ \\
\hline DENV-3C & 1,4 & 0,1 \\
\hline DENV-3S & 1,4 & $0^{*}$ \\
\hline
\end{tabular}

(*) Níveis da porcentagem de mistura lipídica não detectados.

Tabela 7 - Carga dos peptídeos em estudo nos pHs 5 e 7,4, onde as cores diferentes dos resíduos indicam: vermelho - resíduos ácidos, azul - resíduos básicos e laranja - resíduos não carregados hidrofóbicos. Dados obtidos através de Protein Calculator. (111) Tabela elaborada pela autora.

\begin{tabular}{|c|c|c|c|}
\hline Peptídeos & Sequência & $\begin{array}{l}\text { Carga } \\
\text { (pH 5) }\end{array}$ & $\begin{array}{c}\text { Carga } \\
\text { (pH 7,4) }\end{array}$ \\
\hline PFDEN & DRGWGNGCG $L F G K G S\llcorner$ & 1,2 & 0,7 \\
\hline DENV-1C & ANFVCRRTFVDRGWGNGSGLFGKGSLLTCAKFKSVT & 5,2 & 4,6 \\
\hline DENV-1S & ANFVSRRTFVDRGWGNGSGLFGKGSLLTSAKFKS VT & 5,2 & 4,8 \\
\hline DENV-3C & QNYVCKHTYVDRGWGNGSGLFGKGS LVTCAKFQS LE & 3,4 & 1,8 \\
\hline DENV-3S & QNY VSKHTYVDRGWGNGSG $L F G K G S \perp \vee T S A K F Q S\llcorner E$ & 3,4 & 1,9 \\
\hline
\end{tabular}

\subsubsection{Espalhamento de luz dinâmico (DLS)}

Observada a capacidade dos peptídeos de induzir a mistura lipídica, utilizamos o método de espalhamento dinâmico de luz (DLS) para agora estudarmos esse evento através da quantificação do aumento do tamanho das LUVs com a adição dos peptídeos. Na Figura 16, vemos que os resultados de DLS nos mostram o que já esperávamos vendo os experimentos de mistura lipídica, onde a razão mínima L/P igual a 200 não causa mudanças 
significativas nos tamanhos das vesículas, apenas com a adição do DENV-1C que possui uma capacidade fusogênica maior que os demais peptídeos. Já para a razão L/P igual a 45, vemos um aumento no tamanho das vesículas, em que podemos considerar um efeito de fusão, porém sem descartar a agregação dos lipossomos. Isto está de acordo com Olivier (106), que observou em seus estudos com o peptídeo de fusão para o sorotipo 2 da Dengue através de experimentos por Crio-Microscopia Eletrônica de Transmissão (Cryo-TEM) que o DENV-2 induz não somente a fusão entre as vesículas, mas também a formação de clusters vesiculares. Comportamento similar pode ser visto nos valores dos tamanhos das vesículas puras, que tem um diâmetro de $42,9 \mathrm{~nm}$, e na presença dos peptídeos que são apresentados na Tabela 8. Na adição dos peptídeos na razão L/P de 45, observamos que há vesículas com um pequeno aumento no raio, que não chega nem ao dobro, na maioria dos casos; mas também temos vesículas 10 vezes maiores, que ao tudo indica são os agregados vesiculares.

Tabela 8 - Distribuição do tamanho das vesículas expresso como o raio hidrodinâmico (nm), obtidos nos experimentos de DLS, compostas por POPC/POPG, puras e com a adição dos peptídeos DENV-1 e 3 em pH 5. Tabela elaborada pela autora.

\begin{tabular}{ccc}
\hline & $\begin{array}{c}\text { Raio (nm) } \\
\text { 200:1 }\end{array}$ & Raio (nm) \\
\hline +DENV-1C & 116,1 & 65,0 \\
& & 531,9 \\
\hline & & 54,0 \\
+DENV-1S & 51,6 & 91,9 \\
& & 422,0 \\
\hline +DENV-3C & 55,3 & 51,6 \\
& & 412,4 \\
\hline & & 74,6 \\
+DENV-3S & 54,0 & 496,2 \\
\hline
\end{tabular}



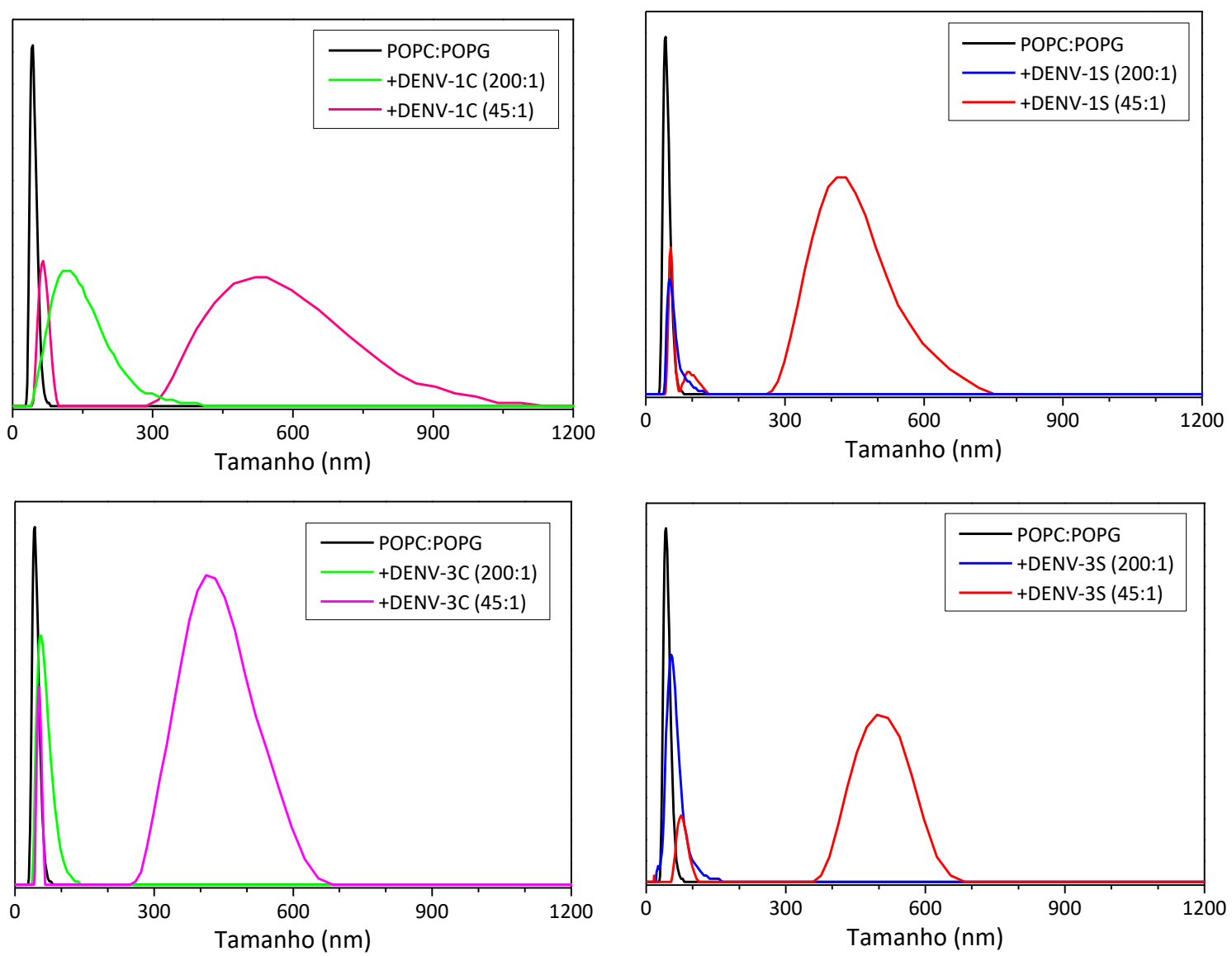

Figura 16 - Distribuição do volume (relativo\%) de LUVs de POPC/POPG, na ausência e na presença dos peptídeos de fusão dos sorotipos 1 e 3 da Dengue. Figura elaborada pela autora.

\subsubsection{Estrutura Secundária por Dicroísmo Circular}

Para avaliarmos a estrutura secundária dos peptídeos e as modificações que eles sofrem ao interagir com modelos de membranas, realizamos experimentos de dicroísmo circular (CD). Os espectros são apresentados nas Figuras 17 e 18 e os dados estão em elipticidade molar por resíduo.

Segundo Modis, na glicoproteína E, encontram-se três domínios com enovelamentos baseados em grande parte em folha- $\beta$, como mostrados anteriormente na Figura 9. 0 domínio II, que apresenta o peptídeo de fusão, suporta um loop no seu topo com uma sequência conservada em todas as flaviviroses e estes resíduos hidrofóbicos são essenciais 
para sua atividade de fusão. (41) Em nosso caso, estruturas secundárias não foram encontradas nos espectros obtidos, tendo sido o sinal detectado típico de uma estrutura desordenada, que é caracterizada por uma única banda em torno de $200 \mathrm{~nm}$. (112) $\mathrm{Na}$ presença dos modelos de membrana, não percebemos alterações significativas nos espectros, ou seja, os peptídeos mantiveram estruturas majoritariamente desordenadas mesmo na presença dos lipossomos. Mendes mostrou que o peptídeo de fusão com 13 resíduos (98-110) exibe estrutura desordenada em solução, o que ele supôs ser devido ao alto conteúdo de glicinas presente no peptídeo. (34)

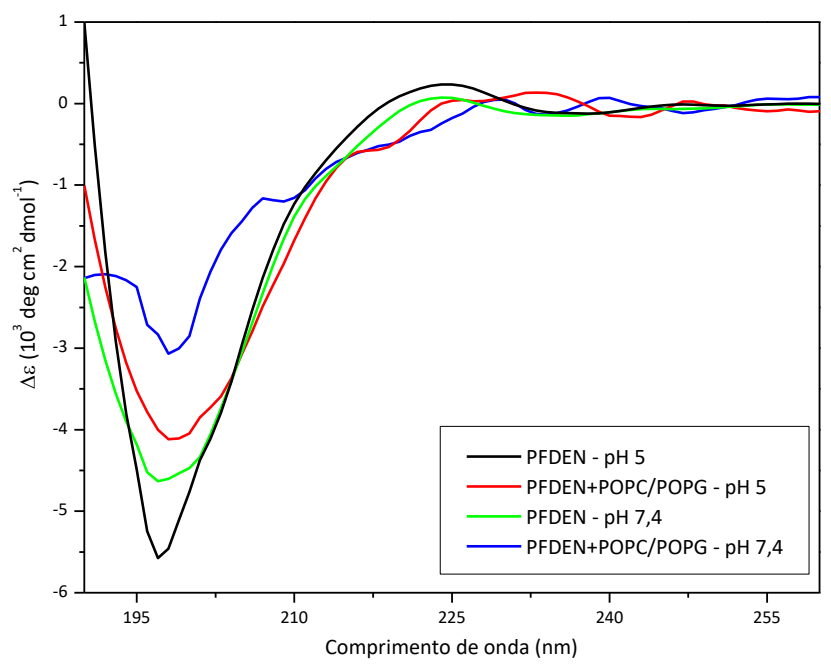

Figura 17 - Espectros de CD do peptídeo de fusão da dengue em solução e com a adição de vesículas de POPC/POPG nos pHs 5 e 7,4. Figura elaborada pela autora. 

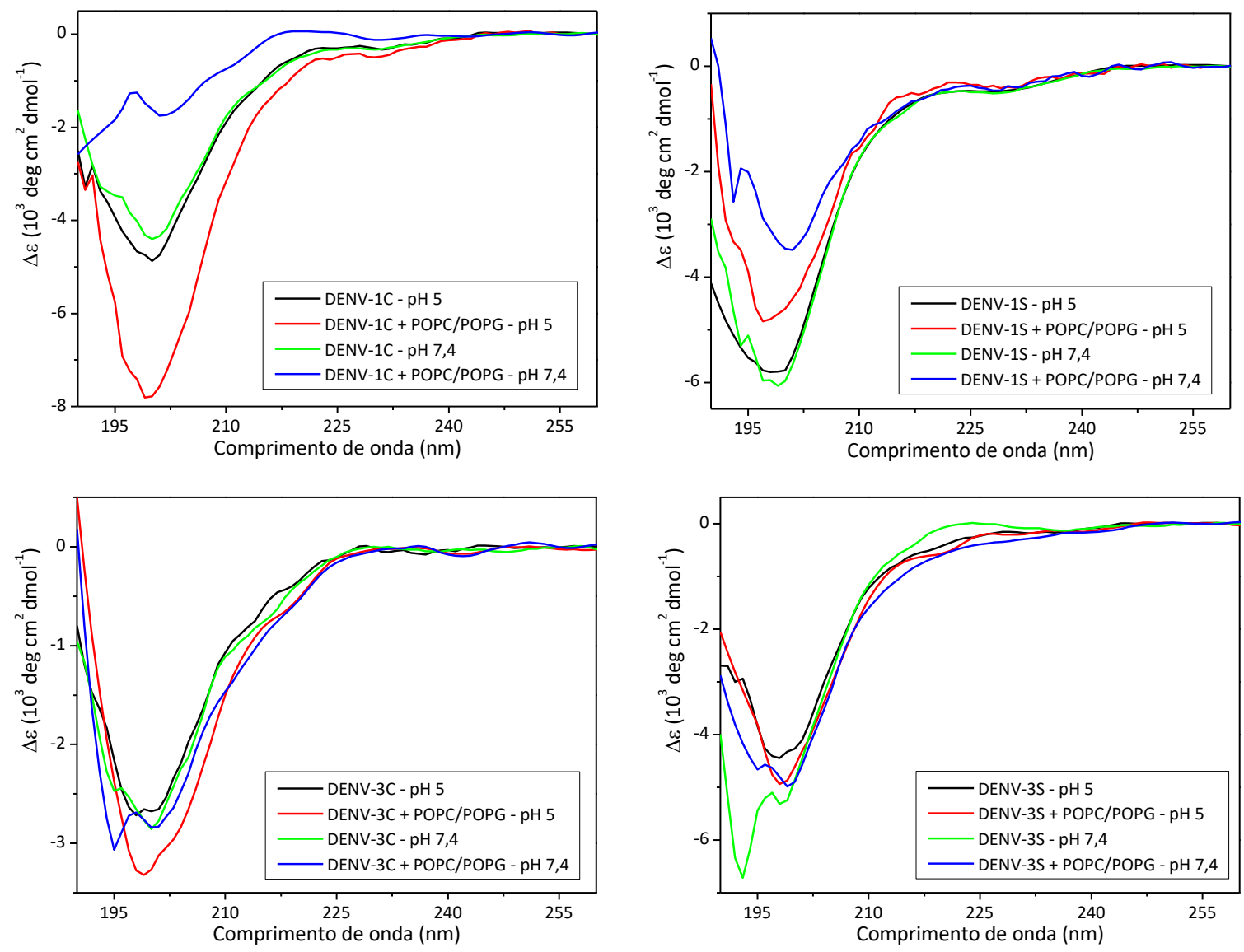

Figura 18 - Espectros de CD do peptídeo de fusão e suas regiões flanqueadoras dos sorotipos 1 e 3 da dengue, em solução e com a adição de vesículas de POPC/POPG nos pHs 5 e 7,4. Figura elaborada pela autora.

A falta de estruturação dos peptídeos na presença dos miméticos de membrana nos levou a questionar a sua capacidade de se enovelar em alguma condição. Para investigarmos o potencial dos peptídeos de se estruturarem, utilizamos o agente indutor de estrutura secundária TFE (113) em diferentes proporções e os espectros daí resultantes são apresentados na Figura 19. Como podemos notar, o TFE foi capaz de promover a estruturação de todos os peptídeos, que mostram bandas típicas de estruturas em $\alpha$-hélice em torno de 205 e $220 \mathrm{~nm}$. Uma diferença interessante entre os peptídeos contendo a ponte dissulfeto (DENV-1C e DENV-3C) e aqueles em que a ponte está ausente está na melhor definição da banda em torno de $220 \mathrm{~nm}$ para os últimos. Isto sugere que a presença da ponte dissulfeto na estrutura inicialmente desordenada na ausência de TFE de alguma 
forma trava o arranjo estrutural, não permitindo que o peptídeo adquira o mesmo grau de estruturação em hélice observado para os peptídeos sem a ponte dissulfeto.
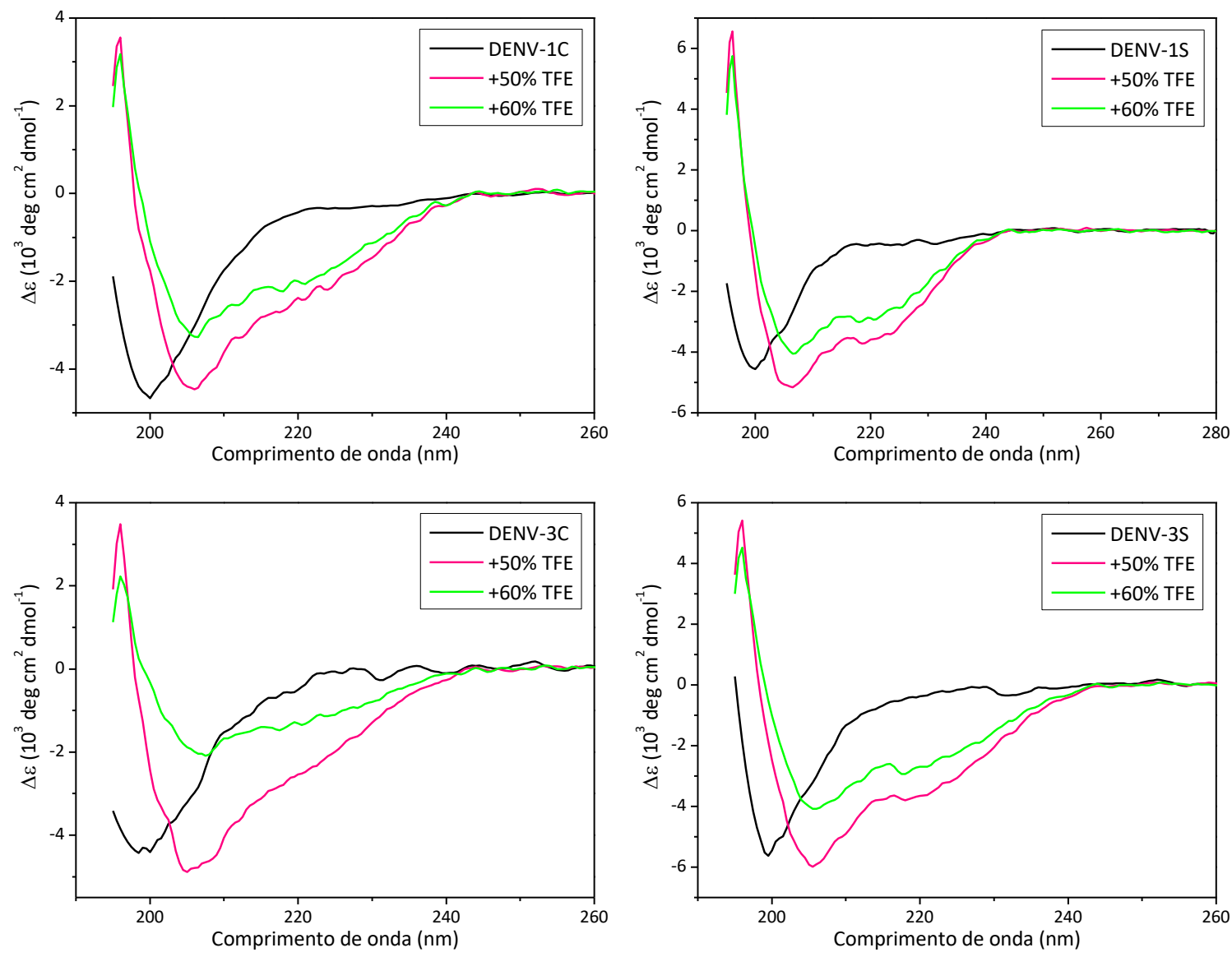

Figura 19 - Espectros de CD dos peptídeos de fusão e suas regiões flanqueadoras dos sorotipos 1 e 3 da Dengue em solução tampão fosfato pH 7,4 e com diferentes concentrações de TFE. Figura elaborada pela autora.

Os resultados de CD e de capacidade fusogênica (Seção 4.1.1) como um todo mostram que os peptídeos são capazes de promover a mistura lipídica entre vesículas, mesmo não adotando grau de estruturação secundária significativo. A capacidade de adquirir estrutura helicoidal na presença de TFE sugere que a manutenção de estruturas desordenadas quando na presença dos miméticos de membrana deva advir de alguma relevância funcional oriunda da maior flexibilidade experimentada por estruturas desordenadas. 


\subsubsection{Constantes de partição e localização do Trp - Fluorescência}

Sackett afirma que a ligação do peptídeo na vesícula é um pré-requisito para a fusão. (114) Para quantificarmos essa ligação, realizamos experimentos monitorando as variações na intensidade do espectro de fluorescência do resíduo de Trp presente nos peptídeos DENV-1 e 3, na concentração de $1 \mu \mathrm{M}$, enquanto titulávamos soluções de vesículas de POPC/POPG em diversas concentrações, entre 30 e 400-500 $\mu \mathrm{M}$. Lembrando, como mencionado anteriormente, não detectamos mistura lipídica abaixo de uma razão L/P igual a 200, razão mínima para que o evento ocorra e acima de 45, por não conseguirmos diferenciar a mistura lipídica da agregação das vesículas. Os espectros de emissão são apresentados na Figura 20 e as curvas para cálculo da constante de partição, obtidas a partir das intensidades desses espectros, assim como os seus ajustes pela Equação 2 estão apresentados na Figura 21. Os valores de $K_{p}$ obtidos são mostrados na Tabela 9.

Através do valor de $K_{p}$ podemos obter a fração molar de peptídeo ligado à membrana, $x_{L}$, que é dada pela equação

$$
x_{L}=\frac{K_{P}[L]}{[W]+K_{P}[L]}
$$

e que nos dá uma informação mais quantitativa da ligação peptídeo-membrana. Foram obtidos valores de $K_{p}$ da ordem de $10^{6}$, indicando que o peptídeo se ligou à superfície da membrana com alta afinidade, sendo maior para o DENV-1 e quando comparados entre as sequências análogas, maior para os peptídeos com a ponte dissulfeto, como vemos na Tabela 9. 

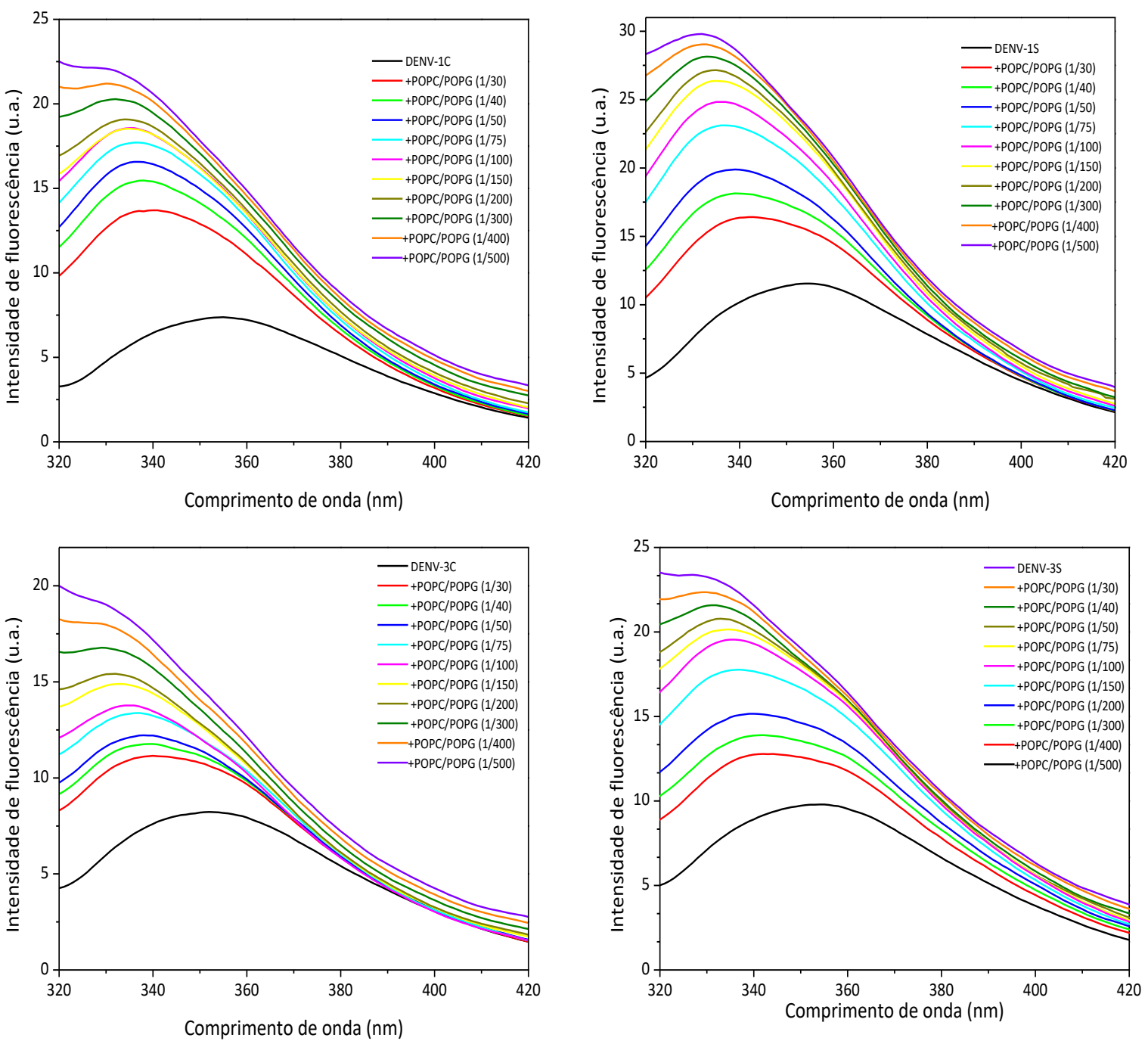

Figura 20 - Espectros de emissão do Trp dos peptídeos DENV-1 e 3 na ausência e na presença de diversas concentrações de LUVs de POPC/POPG em pH 5. Figura elaborada pela autora. 


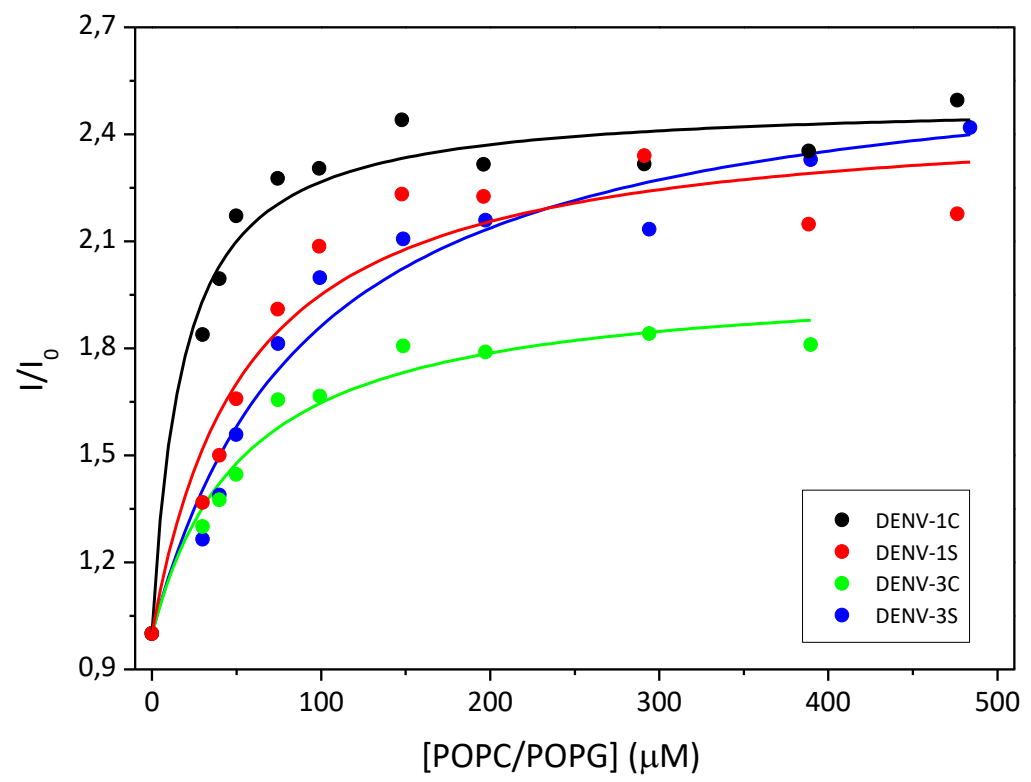

Figura 21 - Determinação da constante de partição, $K_{p}$, dos peptídeos em estudo, através da mudança da intensidade de fluorescência do Trp na presença das vesículas em pH 5. Figura elaborada pela autora.

Tabela 9 - Constante de partição e fração molar dos peptídeos DENV-1 e 3 ligados à membrana, em pH 5. Tabela elaborada pela autora.

\begin{tabular}{ccc}
\hline Peptídeo & $K_{\mathrm{P}}\left(\times 10^{6}\right)$ & $\mathrm{x}_{\mathrm{L}}$ \\
\hline DENV-1C & $3,1 \pm 0,6$ & 0,20 \\
\hline DENV-1S & $1,1 \pm 0,3$ & 0,08 \\
\hline DENV-3C & $1,0 \pm 0,2$ & 0,08 \\
\hline DENV-3S & $0,6 \pm 0,1$ & 0,05 \\
\hline
\end{tabular}

Uma vez determinado o valor da constante de partição do peptídeo entre o meio e a vesícula modelo, interessamo-nos por investigar o grau de inserção dos peptídeos no mimético de membrana utilizado. Para tanto, estudamos a acessibilidade do resíduo de Trp ao meio aquoso através de estudos de supressão da fluorescência do Trp pela acrilamida. A acrilamida é uma molécula solúvel e sua acessibilidade ao Trp leva a um processo de supressão de sua fluorescência.

Os espectros de emissão dos peptídeos, na ausência e na presença das vesículas (razão molar L/P de 45) são apresentados nas Figuras 22-24 e indicam que o peptídeo de 
fusão PFDEN interage com a membrana em ambos os $\mathrm{pHs}$, devido ao grande deslocamento do comprimento de onda máximo de emissão do Trp que foi de $12 \mathrm{~nm}$ para o pH 5 e $4 \mathrm{~nm}$ para o pH 7,4, implicando que o Trp no PFDEN está em um ambiente mais hidrofóbico quando adicionadas as vesículas. Para os peptídeos maiores, os DENVs, há uma menor inserção do Trp na membrana em pH 5, pois não há um deslocamento significativo para o espectro de emissão. Já no pH 7,4, observamos uma inserção nas vesículas para o peptídeo DENV-1, mas não para o DENV-3, como vemos na Tabela 11.

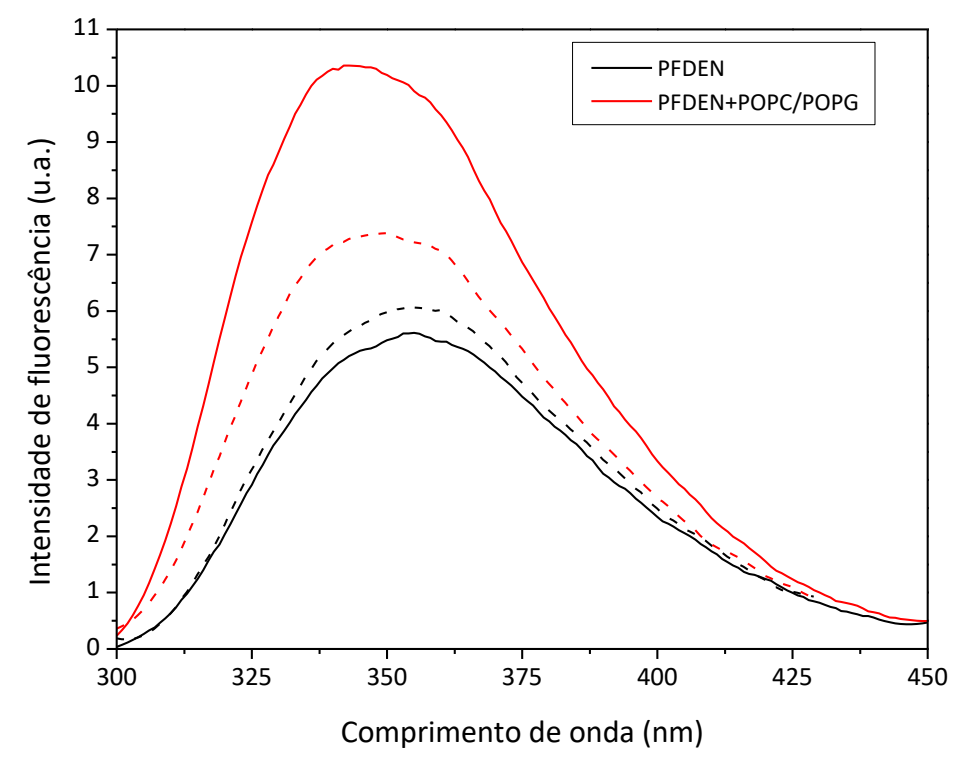

Figura 22 - Espectros de emissão dos peptídeos PFDEN na ausência (linha preta) e na presença (linha vermelha) das vesículas de POPC/POPG, nos pHs 5 (linha sólida) e 7,4 (linha tracejada). Figura elaborada pela autora.

A partir dos espectros de fluorescência do Trp na presença de concentrações crescentes de acrilamida, podemos construir as curvas de Stern-Volmer. Os resultados para a supressão do Trp presente nos peptídeos pela acrilamida, na ausência e na presença das vesículas de POPC/POPG estão apresentadas nas Figuras 25-27, e as constantes resultantes do ajuste da curva são mostradas nas Tabelas 10 e 11, para os pHs 5 e 7,4, respectivamente. 


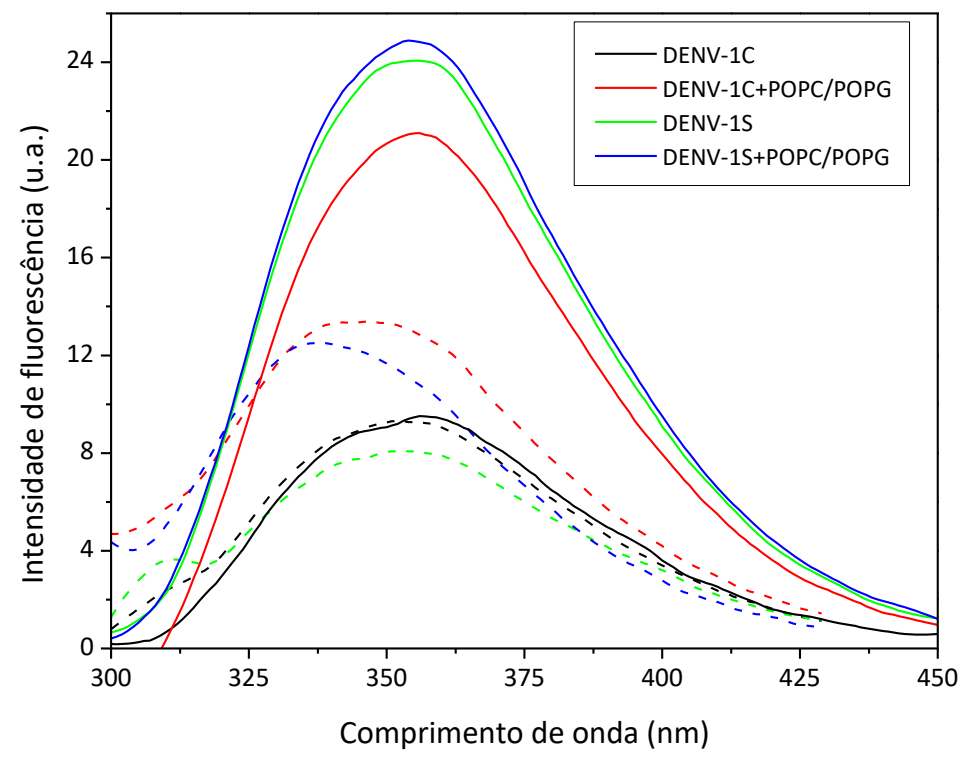

Figura 23 - Espectros de emissão dos peptídeos DENV-1, na ausência e na presença das vesículas de POPC/POPG, nos pHs 5 (linha sólida) e 7,4 (linha tracejada). Figura elaborada pela autora.

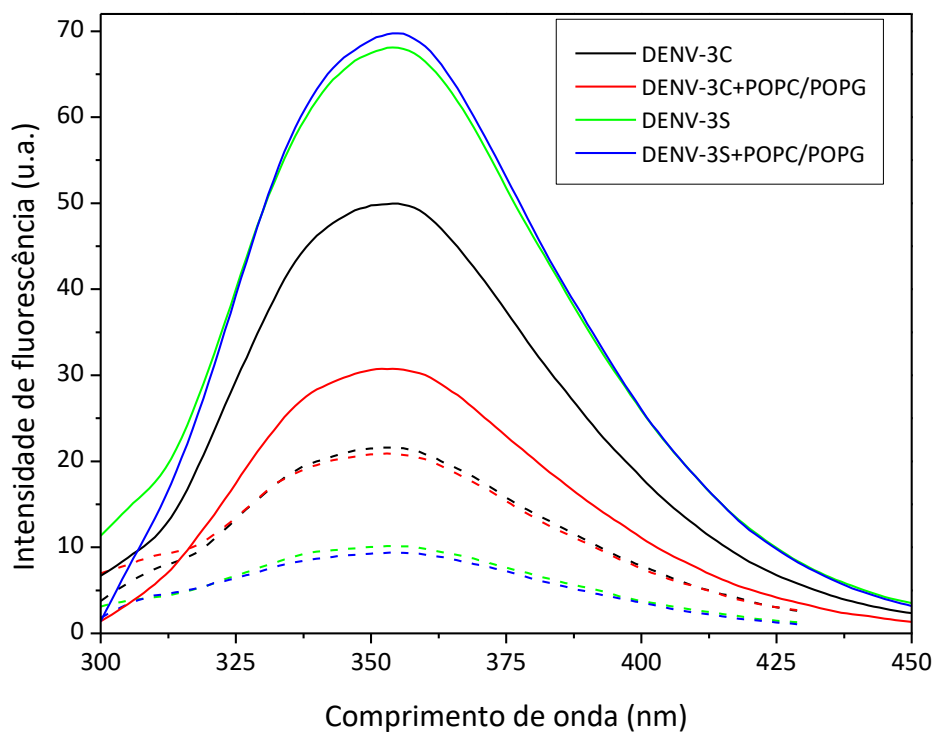

Figura 24 - Espectros de emissão dos peptídeos DENV-3, na ausência e na presença das vesículas de POPC/POPG, nos pHs 5 (linha sólida) e 7,4 (linha tracejada). Figura elaborada pela autora. 


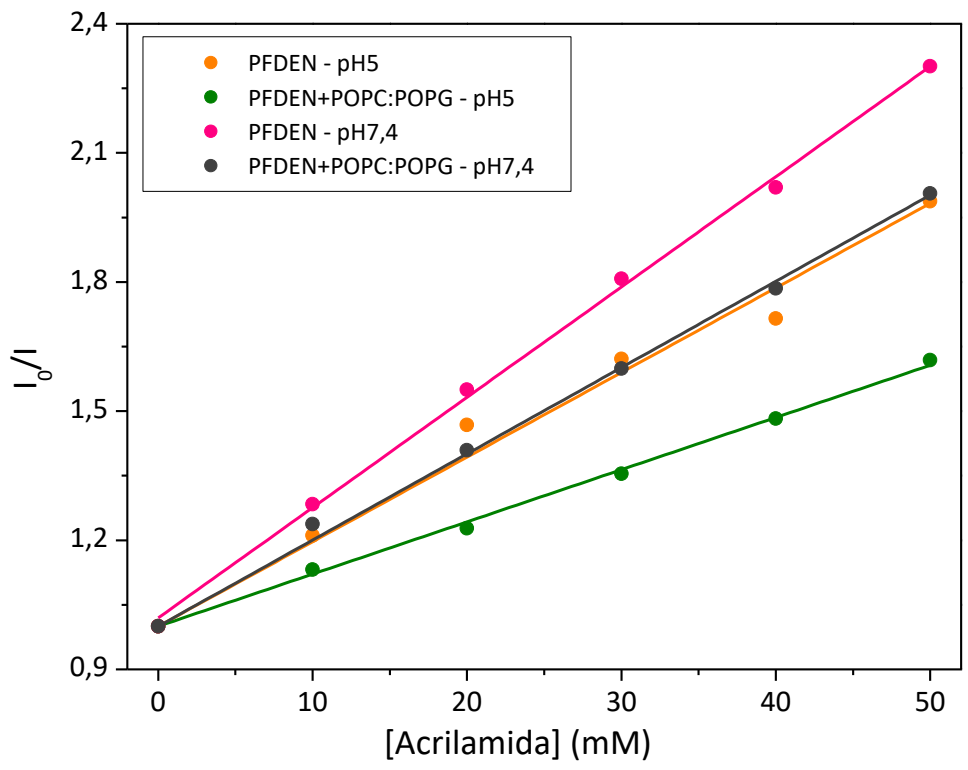

Figura 25 - Gráfico de Stern-Volmer da supressão de fluorescência pela acrilamida do peptídeo de fusão da dengue em solução aquosa e na presença de vesículas de POPC/POPG (4/1) nos pHs 5 e 7,4. Figura elaborada pela autora.
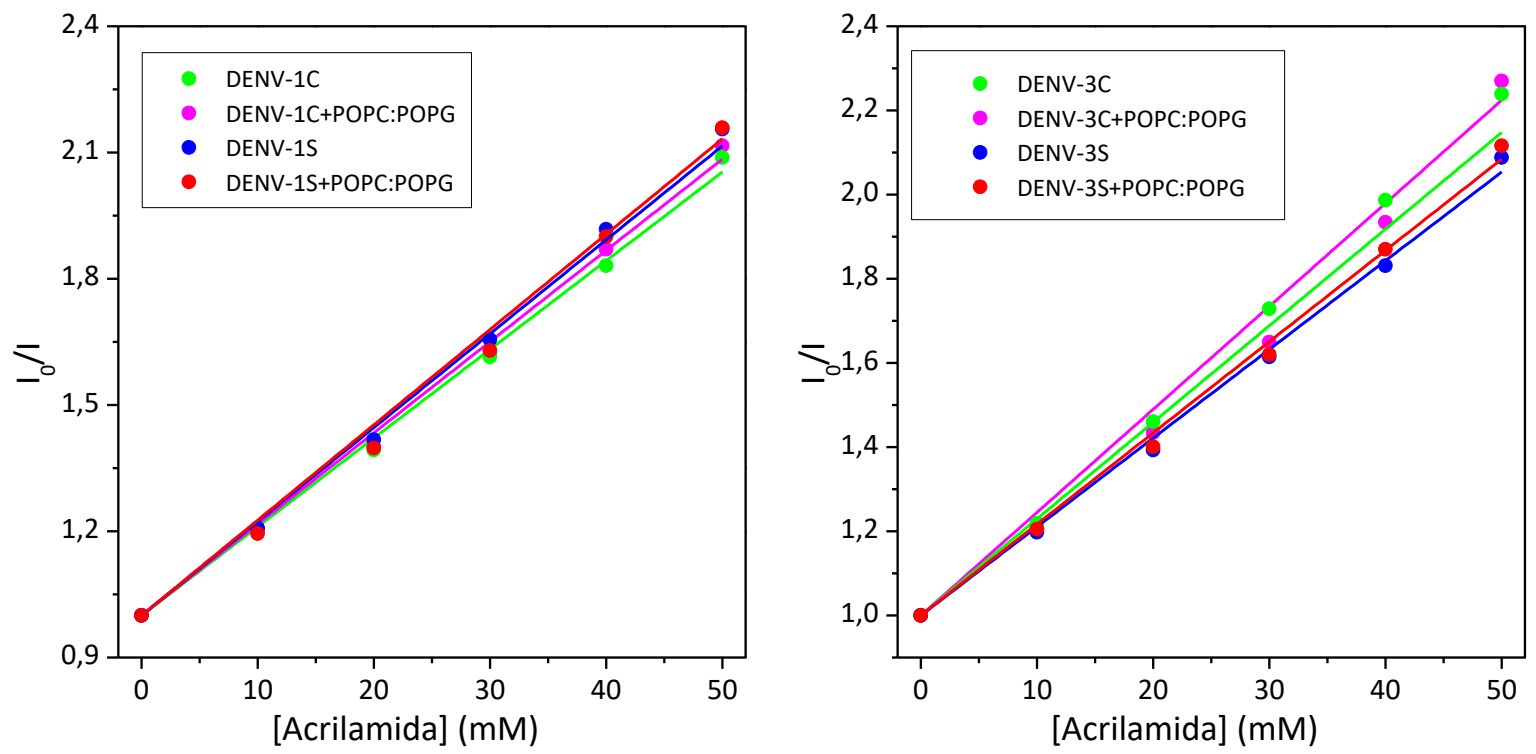

Figura 26 - Gráfico de Stern-Volmer da supressão de fluorescência pela acrilamida dos peptídeos de fusão do sorotipo 1 e 3 da dengue em solução aquosa e na presença de vesículas de POPC/POPG (4/1) no pH 5. Figura elaborada pela autora. 

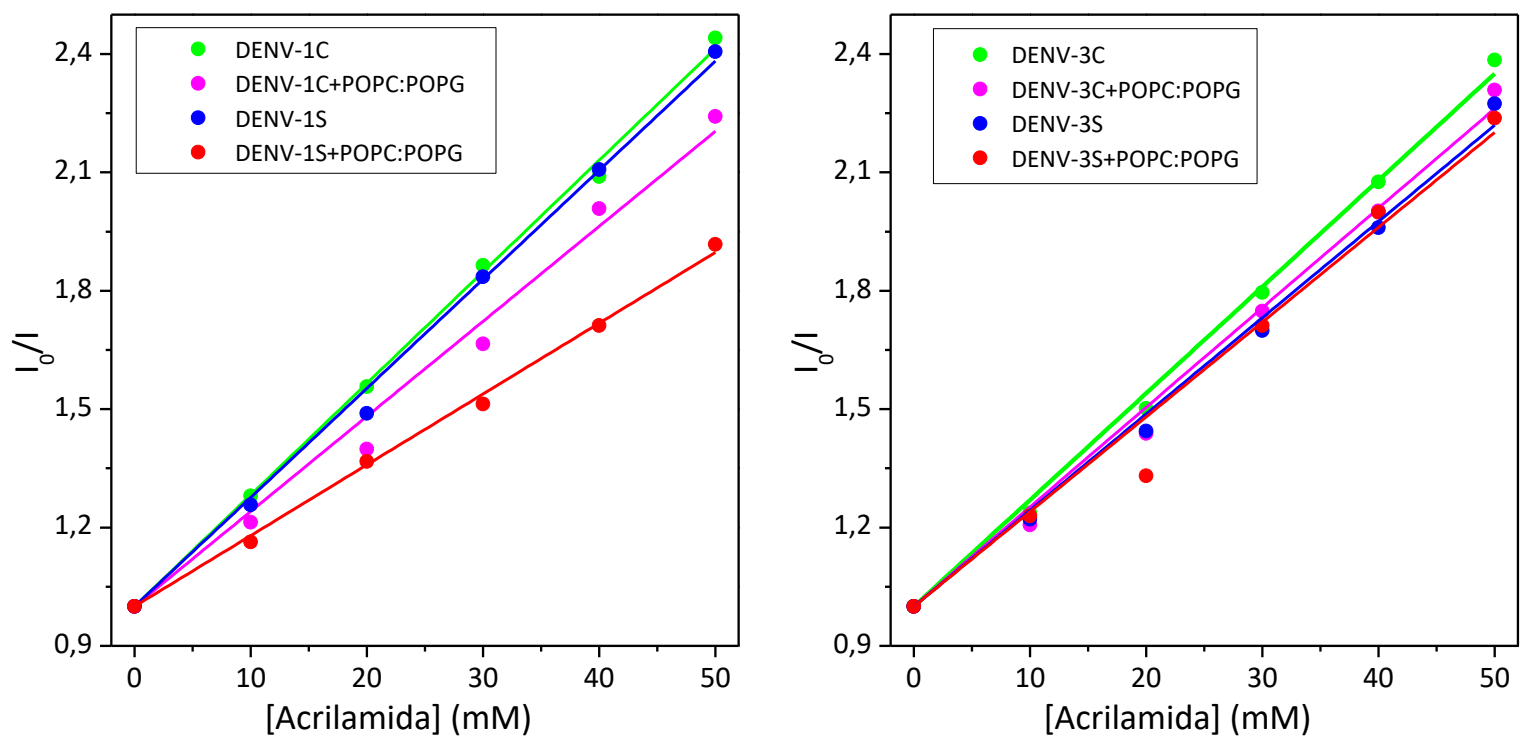

Figura 27 - Gráfico de Stern-Volmer da supressão de fluorescência pela acrilamida dos peptídeos de fusão do sorotipo 1 e 3 da dengue em solução aquosa e na presença de vesículas de POPC/POPG (4/1) no pH 7,4. Figura elaborada pela autora.

Dos valores da constante de supressão nas Tabelas 10 e 11, vemos que os peptídeos em solução possuem altos valores de $\mathrm{K}_{s v}$, indicando alta exposição do fluoróforo ao solvente, sendo maiores para os peptídeos de fusão com as regiões flanqueadoras (DENV-1 e 3). Quando adicionadas às vesículas, há uma diminuição significativa do Ksv para o PFDEN, nos dois pHs, sugerindo que o peptídeo ao interagir com os modelos de membrana muda a exposição de seu resíduo de Trp ao solvente. Já para os peptídeos com as regiões flanqueadoras, vemos que o DENV-1 na presença dos miméticos não tem a exposição do Trp alterada em pH 5, mas apresenta uma mudança significativa em $\mathrm{pH}$ 7,4. O peptídeo DENV-3 não experimenta alterações na acessibilidade do Trp em nenhum pH. Em vários dos casos em que não percebemos mudanças de acesso do solvente ao Trp, temos a alteração da intensidade de fluorescência como mudança mais marcante nos espectros, indicando que há a interação peptídeo-membrana. 
Tabela 10 - Valores de Ksv para os peptídeos em miméticos de membrana e em solução aquosa em pH 5. Tabela elaborada pela autora.

\begin{tabular}{ccccc}
\hline Peptídeos & $\lambda_{\boldsymbol{m a ́ x}}^{\text {solução }}(\mathrm{nm})$ & $\boldsymbol{K}_{\boldsymbol{S V}}^{\boldsymbol{s o l u c ̧ a ̃ o}}\left(\mathbf{M}^{-\mathbf{1}}\right)$ & $\lambda_{\boldsymbol{m a ́ x}}^{P O P C: P O P G}(\mathbf{n m})$ & $\boldsymbol{K}_{S V}^{P O P C: P O P G}\left(\mathbf{M}^{-1}\right)$ \\
\hline PFDEN & 355 & 19,7 & 343 & 12,1 \\
\hline DENV-1C & 356 & 21,1 & 356 & 21,7 \\
\hline DENV-1S & 356 & 22,6 & 354 & 22,3 \\
\hline DENV-3C & 354 & 24,5 & 352 & 23,8 \\
\hline DENV-3S & 354 & 21,1 & 354 & 21,7 \\
\hline
\end{tabular}

Tabela 11 - Valores de Ksv para os peptídeos em miméticos de membrana e em solução aquosa em pH 7,4. Tabela elaborada pela autora.

\begin{tabular}{ccccc}
\hline Peptídeos & $\lambda_{\boldsymbol{m a ́ x}}^{\text {soluc̃a }}(\mathbf{n m})$ & $\boldsymbol{K}_{\boldsymbol{S V}}^{\text {solução }}\left(\mathbf{M}^{-\mathbf{1}}\right)$ & $\lambda_{\text {máx }}^{P O P C: P O P G}(\mathbf{n m})$ & $\boldsymbol{K}_{\boldsymbol{S V}}^{P O P C: P O P G}\left(\mathbf{M}^{-\mathbf{1}}\right)$ \\
\hline PFDEN & 354 & 26,2 & 350 & 20,0 \\
\hline DENV-1C & 355 & 28,3 & 346 & 24,1 \\
\hline DENV-1S & 353 & 27,6 & 339 & 17,9 \\
\hline DENV-3C & 354 & 27,0 & 353 & 25,0 \\
\hline DENV-3S & 354 & 24,4 & 354 & 24,0 \\
\hline
\end{tabular}

Esses resultados sugerem que os diferentes peptídeos possam ter distintos mecanismos de docking na vesícula lipídica, que é dependente de $\mathrm{pH}$ e da sequência primária. Com estas comparações vemos que o PFDEN é mais acessível à membrana do que quando observamos o peptídeo de fusão com suas regiões flanqueadoras, o que sugere que quando inserido na glicoproteína E (ou seja, na presença das regiões flanqueadoras), o peptídeo não se insere totalmente na membrana, necessitando provavelmente de alguma outra mudança conformacional da proteína que catalise a interação. 


\subsubsection{Ressonância paramagnética eletrônica}

Com a finalidade de aprofundarmos os estudos anteriores, obtendo agora informações em nível molecular acerca da interação entre os peptídeos e os miméticos de membrana, foram realizadas medidas de RPE em LUVs de POPC/POPG (4/1) contendo sondas magnéticas na ausência e na presença dos peptídeos PFDEN, DENV-1C, DENV-1C, DENV-3C e DENV-3S, na razão molar L/P de 45/1. As mudanças foram monitoradas pelas moléculas de fosfolipídios marcadas nas posições 5, 7, 10, 12, 14 e 16 (n-PCSL) da cadeia lipídica e na cabeça do fosfolipídio (DOPTC). Nesta seção são apresentados os espectros obtidos (Figura 28) e os resultados da análise desses espectros baseada em parâmetros empíricos, definidos sofre o próprio espectro (v. seção 3.7.1) mostrados nas Figuras 29 e 30.

As medidas foram realizadas à temperatura ambiente, onde todos os lipídios utilizados para mimetizar a membrana estão em sua fase fluida. Pela análise dos espectros podemos observar que não há uma mudança significativa na forma das linhas quando da adição dos peptídeos.

Para obtermos uma investigação mais quantitativa do sistema em estudo, utilizamos o uso de parâmetros empíricos, na Figura 29 são apresentadas o desdobramento hiperfino máximo $\left(A_{\text {máx }}\right)$ e mínimo $\left(A_{\min }\right)$ que podem ser obtidos para marcadores que possuem um regime de movimento mais restrito e nos dão uma visão da viscosidade e empacotamento do microambiente sentido pelo marcador. 

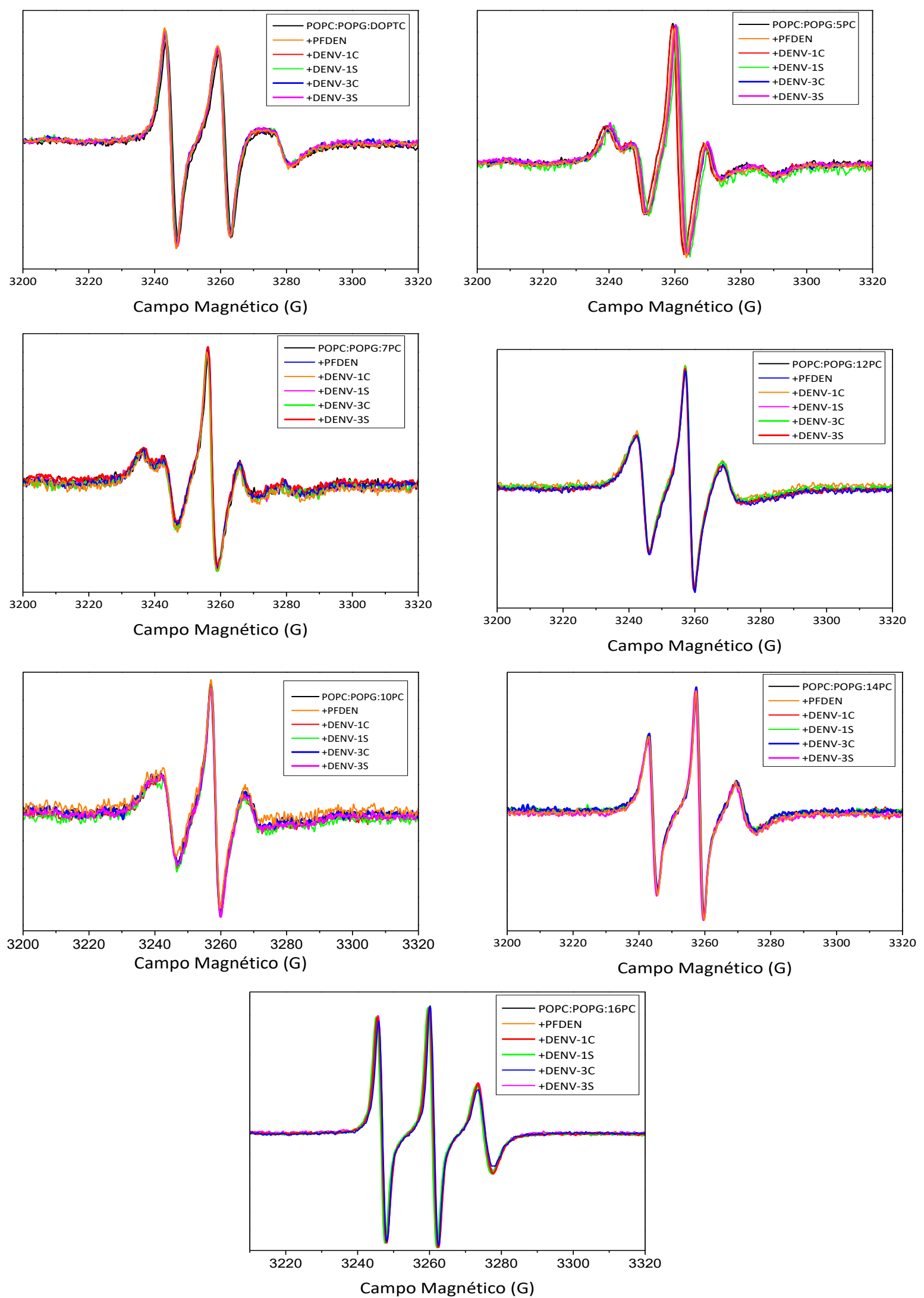

Figura 28 - Espectros de RPE para os marcadores 5, 7, 10, 12, 14 e 16-PCSL e DOPTC em vesículas compostas por POPC/POPG, antes e após a adição dos peptídeos, em pH 5. Figura elaborada pela autora. 

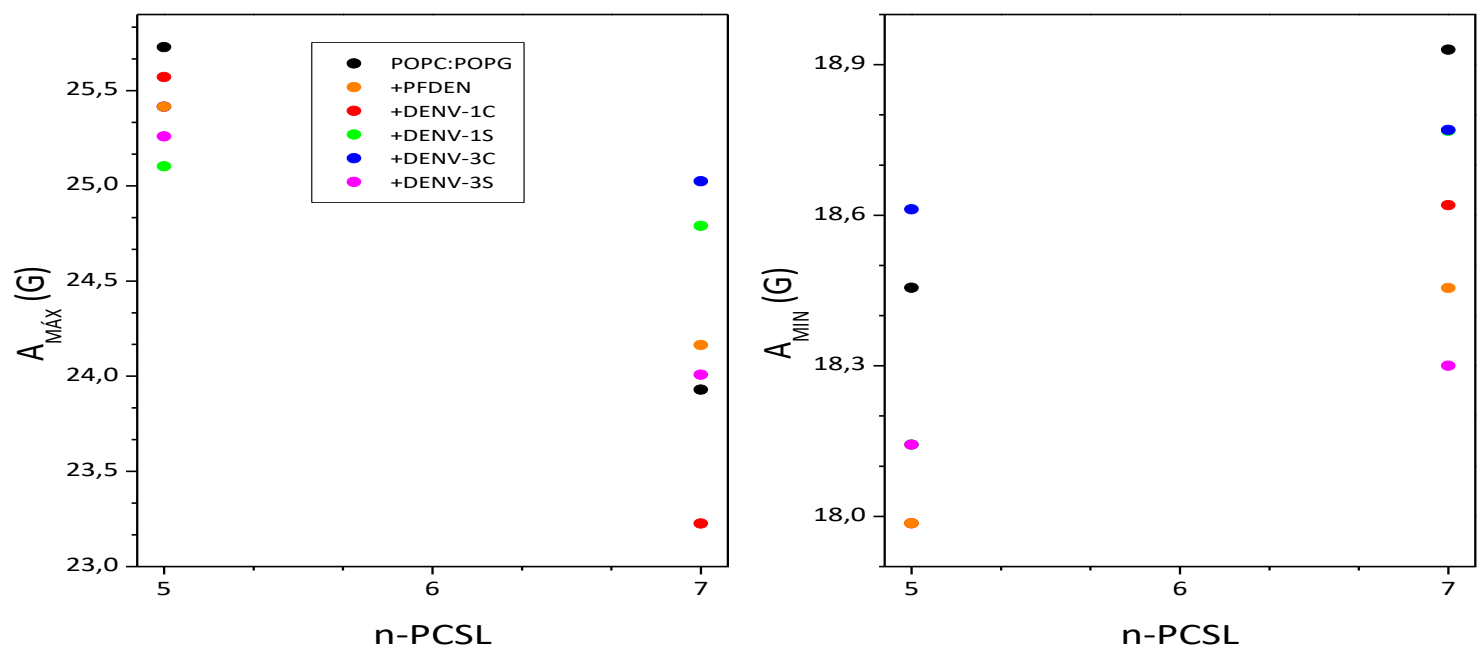

Figura 29 - Parâmetros empíricos, $A_{\text {máx }}$ e $A_{\min }$, obtidos dos espectros para os marcadores 5 e 7-PCSL incorporados em vesículas de POPC/POPG, na ausência e na presença dos peptídeos em pH 5. Figura elaborada pela autora.

Na Figura 30 estão apresentados os parâmetros $h_{-1} / h_{0}$ e $h_{+1} / h_{0}$ que são obtidos através das alturas das linhas de campo alto $\left(h_{+1}\right)$, central $\left(h_{0}\right)$ e baixo $\left(h_{-1}\right)$ dos espectros e podem ser utilizadas para a análise de espectros de sistemas com movimento anisotrópico, para marcadores com grande mobilidade.

Os resultados com a sonda magnética presente no mimético de membrana não foram capazes de reportar alterações significativas na organização dinâmica dos lipídios com a adição dos peptídeos. Os maiores efeitos provocados pela presença dos peptídeos, mesmo que discretos, aconteceram nas regiões próximas à interface membrana-solvente, monitoradas pelas sondas 5-PCSL e 7-PCSL (Figura 29). Essas observações corroboram o que foi observado em nossos experimentos de CD (pouca ou nenhuma estruturação dos peptídeos na presença dos miméticos de membrana) e pouca alteração da acessibilidade do resíduo de Trp ao solvente, indicando, de maneira geral, que os peptídeos são capazes de se particionar na membrana, mas adotam uma conformação não estruturada na superfície da vesícula lipídica. 

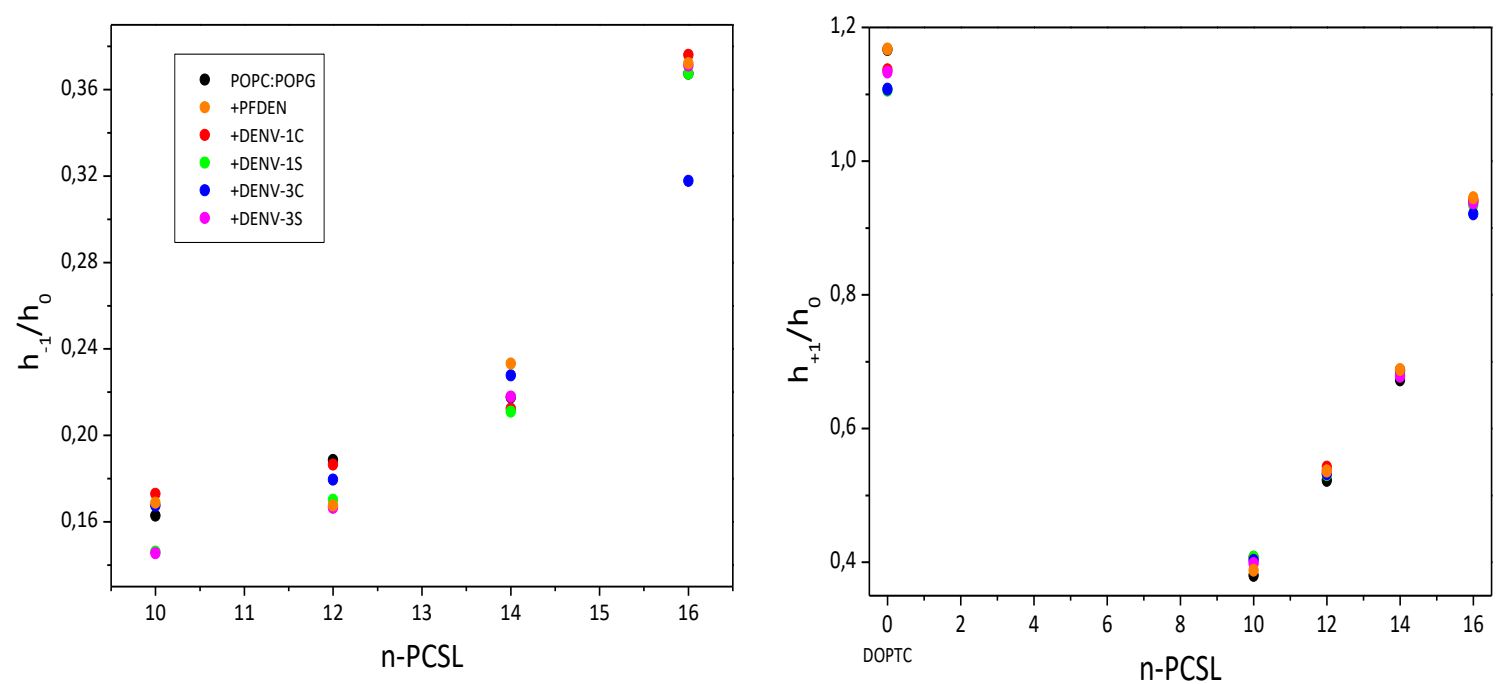

Figura 30 - Parâmetros $h_{-1} / h_{0}$ e $h_{+1} / h_{0}$ para os marcadores 10,12 , 14 e 16-PCSL e DOPTC incorporados em vesículas de POPC/POPG, na ausência e na presença dos peptídeos em pH 5. Figura elaborada pela autora.

Para tentarmos obter informação acerca da estrutura local do peptídeo (em torno de uma sonda magnética), decidimos monitorar, também através do RPE, as mudanças na presença das vesículas utilizando análogos do peptídeo de fusão PFDEN marcados com a sonda paramagnética MTSSL, com as sequências mostradas na Tabela 3. Os espectros obtidos nessa situação são apresentados na Figura 31, onde podemos observar que não há mudanças significativas nas formas dos mesmos com a adição dos miméticos de membrana, o que concorda com os dados anteriores obtidos por CD que apontam para a manutenção da estrutura desordenada dos peptídeos quando da presença das vesículas. 

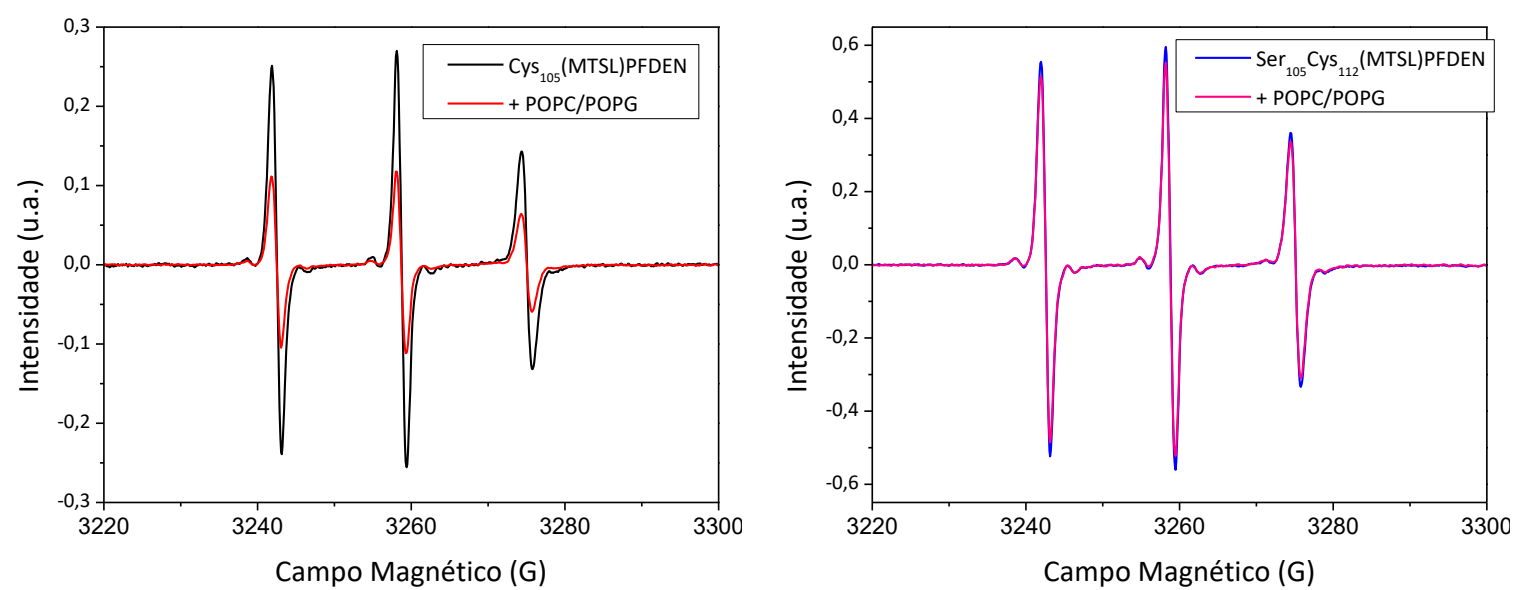

Figura 31 - Espectros de EPR dos análogos dos peptídeos de fusão de fusão PFDEN marcados pela sonda paramagnética MTSSL, na ausência e na presença de vesículas de POPC:POPG na razão molar L/P de 45 em pH 5. Figura elaborada pela autora.

\subsubsection{Calorimetria Diferencial de Varredura (DSC)}

Agora, para examinarmos a interação dos peptídeos com os miméticos de membrana do ponto de vista de alterações promovidas pelos peptídeos no comportamento termotrópico do sistema de vesículas, realizamos experimentos de DSC, desta vez, utilizando vesículas constituídas de DPPC/DPPG, na ausência e na presença dos peptídeos. Esta alteração na composição dos miméticos se fez necessária para que tivéssemos um sistema de membrana que apresentasse transições de fase em torno da temperatura fisiológica e que pudessem, assim, serem usadas para monitorar os efeitos da interação com os peptídeos de interesse. Mantivemos os grupos das cabeças polares (PC e PG) e optamos por cadeias saturadas de dipalmitoil no lugar das cadeias insaturadas de palmitoil-oleil, que apresentam temperaturas negativas da transição para fase fluida. As mudanças estruturais nas bicamadas causadas por agentes externos podem provocar variações na temperatura de transição de fase do fosfolipídio e as alterações do empacotamento lipídico das bicamadas levam a mudanças no comportamento termotrópico dos lipossomos. (115)

As Figuras 32 e 33 mostram os termogramas da mistura binária de lipídios DPPC/DPPG em pH 5 e 7,4, respectivamente, e os efeitos dos peptídeos em seu comportamento 
termotrópico. Primeiramente, podemos verificar que os termogramas correspondentes às amostras sem peptídeo apresentam, ao serem aquecidas, sinais largos e contendo mais de um pico. Isto já foi observado em outros casos de vesículas lipídicas e é sinal de uma mistura lipídica não-ideal. (116-118) Por mistura não-ideal se entende que os lipídios não estão distribuídos de forma aleatória na bicamada, mas sim formando domínios, o que leva a um comportamento termotrópico distinto do que é observado em vesículas contendo apenas um tipo de fosfolipídio. Além desse padrão de picos mais largos, os termogramas apresentam mais de um pico para o que deveria ser a transição principal de uma vesícula de DPPC puro ou DPPG puro. Em particular, as amostras sem peptídeo, nos dois valores de pH, mostram sinais que parecem ser constituídos pela sobreposição de dois picos, um mais estreito e outro mais largo (Figuras 32 e 33). Aqui, adotamos as ideias de Barroso et. al (116), que estudaram misturas de DPPC e DPPS, de que um dos picos se refere à transição de domínios ricos em DPPC e o outro à transição de domínios ricos em DPPG. Como nosso interesse está em identificar potenciais indicações de interação e efeitos oriundos da presença dos peptídeos, não investigamos em maiores detalhes o comportamento termotrópico dessas misturas na ausência dos peptídeos.

$\mathrm{Na}$ presença dos diferentes peptídeos de interesse, vemos que há mudanças substanciais nos termogramas de DSC em todas as condições. Um fato digno de nota está no deslocamento das temperaturas de transição de fase principal para valores maiores do que aqueles observados na ausência dos peptídeos na maior parte das situações estudadas. Ou seja, os peptídeos tornam mais difícil a fluidificação da membrana através da transição do que seria uma fase gel dos domínios lipídicos para uma fase fluida (ou mais fluida). 


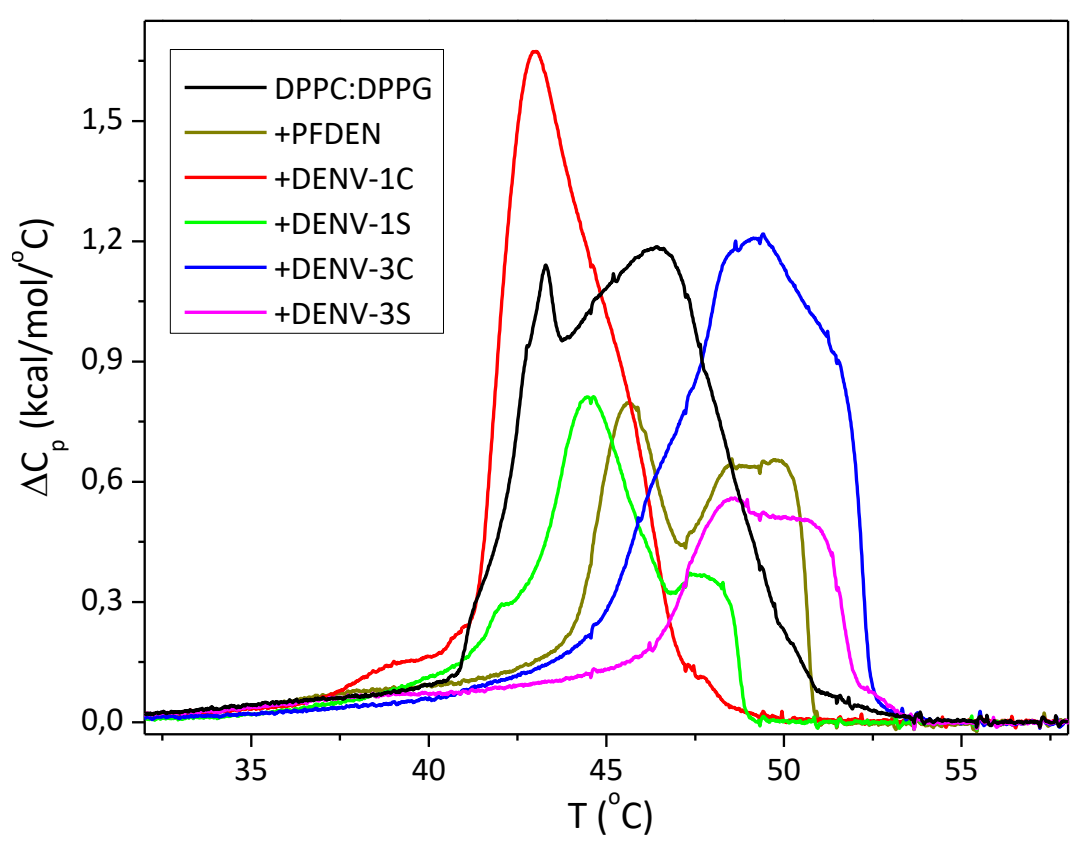

Figura 32 - Termograma de DSC ilustrando os efeitos dos peptídeos no comportamento termotrópico da bicamada lipídica de DPPC/DPPG em pH 5. Figura elaborada pela autora.

Os peptídeos DENV-1C e DENV-3C parecem ser aqueles capazes de promover um maior efeito homogeneizante das vesículas em ambos os pHs, já que é na sua presença que os picos assimétricos de DSC se tornam mais parecidos com um único pico, principalmente em $\mathrm{pH}$ 5. Isto está de acordo com a maior capacidade fusogênica e de ligação às vesículas observada para os peptídeos contendo a ponte dissulfeto nos experimentos anteriores e sugere que tal efeito homogeneizante e capacidade de fusão estejam atrelados, sendo a homogeneização parte do processo de fusão entre as membranas, apesar de não podermos estabelecer, com base nesses experimentos, o que viria primeiro. 


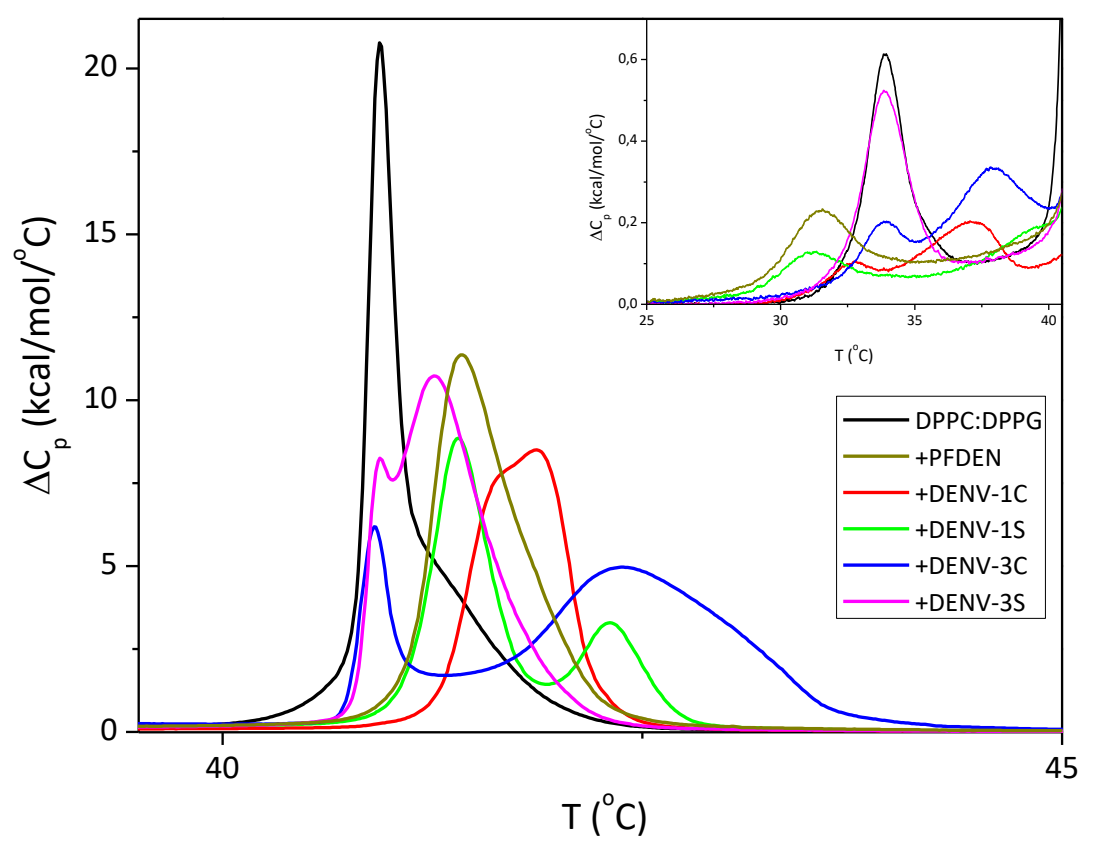

Figura 33 - Termograma de DSC ilustrando os efeitos dos peptídeos no comportamento termotrópico da prétransição (inset) e transição principal da bicamada lipídica de DPPC/DPPG em pH 7,4. Figura elaborada pela autora.

Ao compararmos os termogramas obtidos em pH 5 com aqueles obtidos em $\mathrm{pH} 7,4$, vemos que parece haver uma maior tendência de separação dos picos associados às transições em pH 7,4 como, por exemplo, observado nos traços de DSC para os peptídeos DENV-1S, DENV-3C e DENV-3S (Figura 33), em que os dois picos estão perfeitamente visíveis. O mesmo não é percebido em pH 5, onde se vê que há uma tendência de sobreposição dos picos e prevalecem traços de DSC com forma de linha bem assimétrica e com presença de "ombros". Assim, se tomarmos a diminuição da separação entre os picos das transições como um efeito associado à atividade fusogênica, teremos uma boa correlação entre os traços de DSC medidos em pH 5 e a sabida (e por nós também observada) maior capacidade de fusão de membrana desses peptídeos no mesmo $\mathrm{pH}$. 


\subsubsection{Simulações computacionais por Dinâmica Molecular}

Para complementarmos os resultados experimentais apresentados e discutidos até agora e para tentarmos obter informações em nível molecular de que tipo de alterações ocorrem quando peptídeos e modelos de membrana estão juntos em solução, realizamos simulações de dinâmica molecular, cujos resultados são agora apresentados e foram obtidos como parte de uma colaboração com o Dr. Danilo Olivier.

Todas as figuras desta seção foram elaboradas por Danilo Olivier e os sistemas em estudo são designados por diferentes siglas do restante do texto e são apresentadas na Tabela 5.

\subsubsection{Alterações Estruturais da Bicamada Lipídica}

A ação dos peptídeos durante a interação com a bicamada lipídica de POPC/POPG pode alterar as características estruturais da membrana, bem como pode levar a mudanças conformacionais nos mesmos. A partir do perfil de distribuição de densidade eletrônica é possível verificarmos se a bicamada lipídica sofreu alguma alteração estrutural e entendermos como os componentes do sistema estão interagindo. Na Figura 34 apresentamos a decomposição em componentes dos diferentes sistemas estudados considerando apenas os 30 ns finais de simulação. Ao considerar apenas a porção final da DM estamos considerando apenas a região de equilíbrio. A composição da bicamada conta com 80 lipídios de POPC e 20 lipídios de POPG por monocamada, como já mencionado anteriormente. Pela distribuição de densidade dos lipídios, é possível notarmos que ao final do processo de simulação por DM não há mudanças na proporção de lipídios nas monocamadas, isto é, a razão POPC/POPG continua 4/1. Além disso, não houve alteração na simetria da bicamada em relação ao eixo z. Há uma faixa de transição (de -30 a $-10 \AA$ e +10 a +30 Å) entre os lipídios e o solvente. Na representação da Figura 34, a densidade dos lipídios e solvente são uma sobreposição entre todas as simulações realizadas, indicando que não 
houve mudança no formato da bicamada ao longo da simulação. O posicionamento dos peptídeos (Figura 34 - parte inferior) mostra uma interação na região de interface lipídioágua sem inserção dentro da bicamada lipídica.

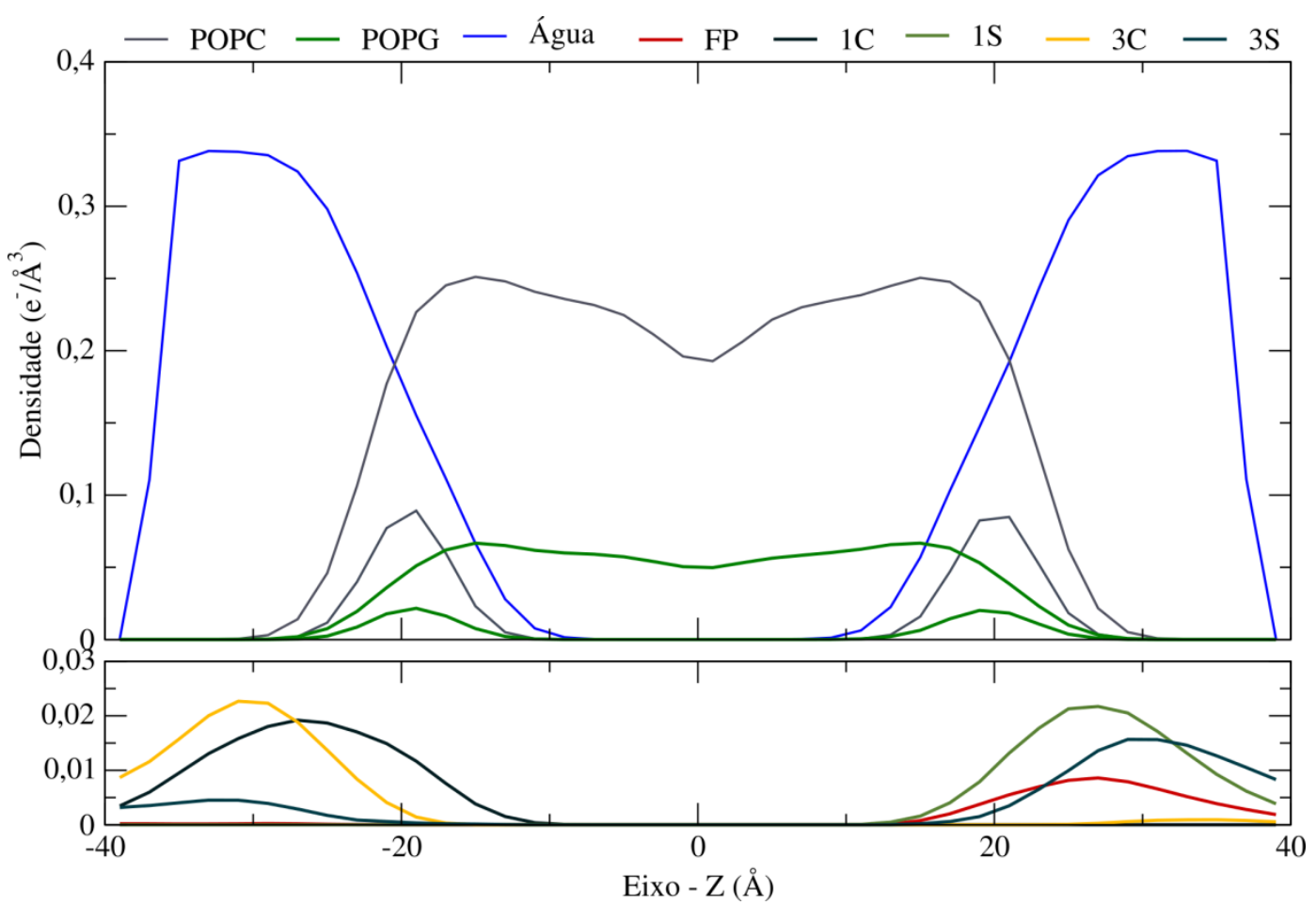

Figura 34 - Perfil de Densidade eletrônica para os peptídeos em interação com a bicamada lipídica. Parte superior: decomposição dos lipídios, água e posicionamento do átomo de fósforo; parte inferior: posicionamento dos peptídeos. Figura elaborada por Danilo Olivier.

A partir do perfil de densidade eletrônica é possível investigar outra propriedade importante da bicamada, a sua espessura. Neste caso, utiliza-se a distância entre os átomos de fósforo em lados opostos da bicamada para estimar a espessura média da bicamada lipídica. Na Figura 34 há uma flutuação ao redor de dois picos (-20 e +20 Å) que representam o posicionamento médio espacial, isto é, por monocamada, e temporal, considerando os 30 ns finais de simulação. Os valores médios para a espessura da bicamada lipídica não foram alterados quando comparados na presença e na ausência dos peptídeos, ficando próximo de $40 \AA ̊$. Em ambos os casos, o valor médio para espessura da bicamada mista de POPC/POPG apresentou valor semelhante à média ponderada dos valores experimentais para os lipídios puros de POPC e POPG, com valor de $39 \AA$. 
Considerando que não houve alteração na espessura média das bicamadas e o posicionamento final dos peptídeos foi próximo à área de interface bicamada-água, é interessante avaliar qual a influência dos peptídeos na área superficial da bicamada de POPC/POPG.

Na ausência dos peptídeos, a bicamada de POPC/POPG apresentou a área por cabeça lipídica com valor médio de $63 \pm 1 \AA^{2}$. O valor médio para área em equilíbrio é condizente com o valor obtido a partir da média ponderada dos dados experimentais para os lipídios de POPC e POPG (119) (120). Na Figura 35 é possível notar que há uma flutuação nos valores médios da área ao longo dos 400 ns de simulação dos peptídeos na presença da bicamada lipídica. Entretanto, a presença dos peptídeos não alterou o valor médio da área por cabeça lipídica, permanecendo o mesmo valor que na ausência, $63 \pm 1 \AA^{2}$. Essas flutuações são inerentes à bicamada lipídica e as mesmas podem ser observadas em dados experimentais.

Os peptídeos não induziram mudanças na densidade eletrônica, área por cabeça lipídica e espessura da bicamada lipídica. Porém, é interessante verificarmos se na interação peptídeo-bicamada houve alguma mudança na orientação das caudas dos lipídios devido à presença dos peptídeos. Para isto utilizamos o parâmetro de ordem que é uma medida do vetor Carbono-Deutério (C-D) em relação ao vetor normal à bicamada lipídica e que é descrito pela $S_{C D}=\left\langle\frac{3 \cos ^{2} \theta-1}{2}\right\rangle$, onde o ângulo $\theta$ é dependente do tempo e refere-se ao ângulo entre o vetor formado pelos átomos C-D e a normal à bicamada, enquanto os brackets denotam a média temporal e espacial (121). 


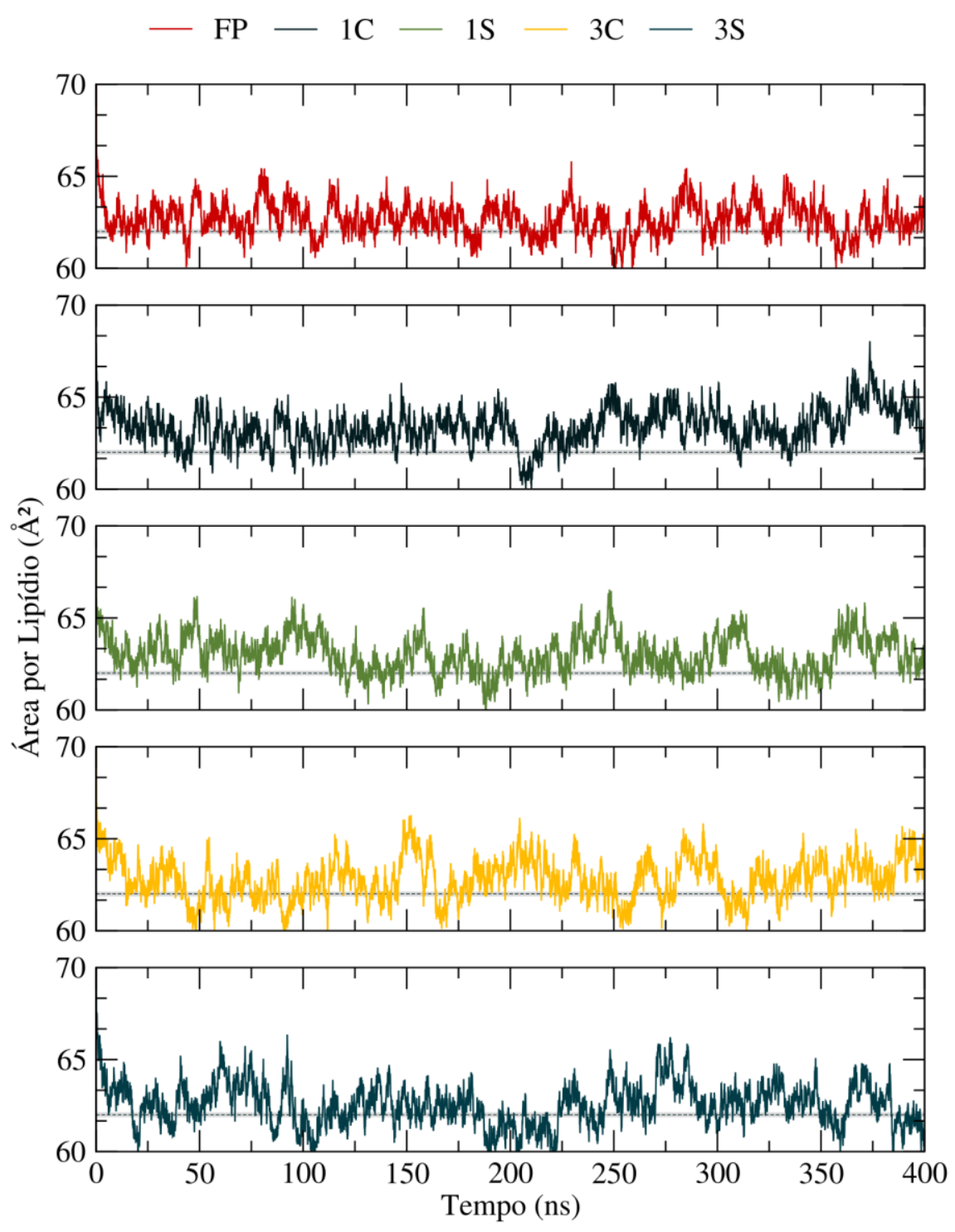

Figura 35 - Variação temporal da área média por cabeça lipídica para bicamada de POPC/POPG na presença de peptídeos. Figura elaborada por Danilo Olivier.

Na Figura 36 apresentamos o parâmetro de ordem para a bicamada pura e na presença dos peptídeos. Além disso, as cadeias hidrocarbônicas são diferentes entre si para os lipídios estudados. Assim, apresentamos o parâmetro de ordem para a cadeia 1 (sn-1) e cadeia 2 (sn-2). O perfil apresentado para o parâmetro de ordem SC-D é semelhante ao encontrado na literatura para simulações de outras bicamadas lipídicas contendo POPC ou POPG (122). Como características das caudas desses lipídios, podemos observar que sn-1 é menor que sn-2. Somando-se a isso, temos que sn-2 possui uma insaturação que dá um 
mínimo característico ao $\mathrm{S}_{C-\mathrm{D}}$ na região dos carbonos 9 e 10. De modo geral, a presença dos peptídeos não alterou o parâmetro de ordem.
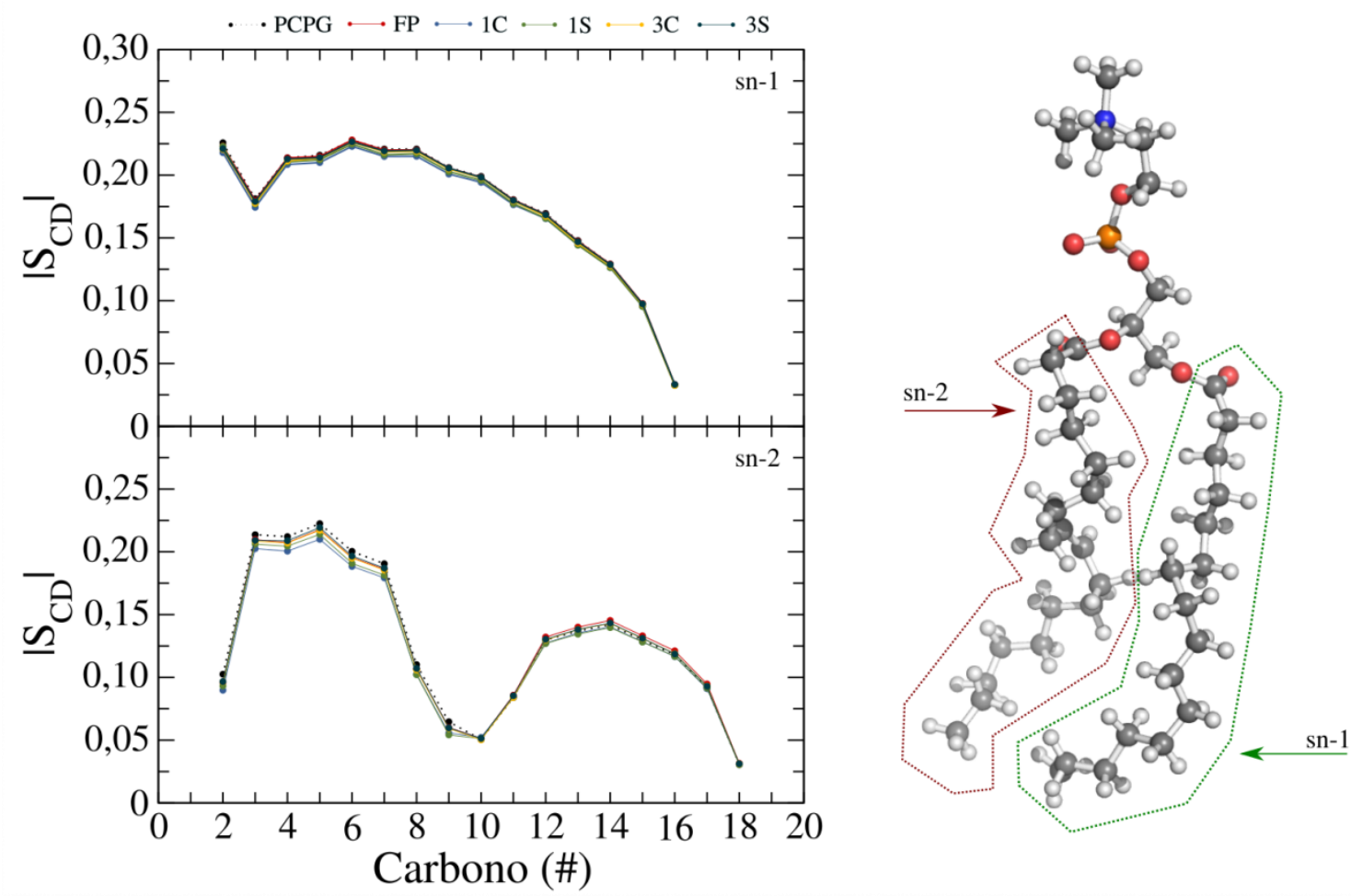

Figura 36 - Parâmetro de ordem para a bicamada lipídica de POPC/POPG na ausência e na presença dos peptídeos. Parâmetro de ordem para as cadeias sn-1 e sn-2 e esquema representativo das cadeias sn-1 e sn-2 para o lipídio de POPC. Figura elaborada por Danilo Olivier.

\subsubsection{Mudanças conformacionais e inserção dos peptídeos virais}

Durante a interação peptídeo-bicamada não foram constatadas mudanças em parâmetros essenciais da bicamada tais como área por lipídio, parâmetro de ordem e densidade eletrônica. Por outro lado, pouco pode-se afirmar sobre o peptídeo através desses parâmetros. A partir do perfil de densidade eletrônica foi observado que os peptídeos ficaram posicionados sobre a superfície da bicamada lipídica. Assim, se faz necessário uma análise sobre as mudanças sofridas pelo peptídeo, bem como, informações sobre o seu posicionamento junto às cabeças polares. 
Peptídeos e proteínas possuem uma conformação tridimensional na qual podem estar presentes diferentes estruturas secundárias, com destaque para as formações de folha- $\beta$, hélice $-\alpha$, turn (região de mudança de direção em formações $\beta$ ) ou ainda regiões sem estrutura definida.

Na Figura 37, apresentamos a evolução temporal para os 5 peptídeos estudados. Ao longo da simulação por DM, o PFDEN apresentou uma pequena faixa de formação de folha$\beta$ ao longo dos primeiros 100 ns. A formação turn foi mais destacada na vizinhança do resíduo 105 e na segunda metade da simulação. Por ser um peptídeo pequeno há uma certa dificuldade de se manter o posicionamento em uma estrutura secundária definida. Assim, uma parte dos aminoácidos permaneceram sem estrutura definida ao longo da dinâmica. $\mathrm{O}$ peptídeo DENV-1C, pertencente ao vírus da dengue do sorotipo 1 e mantendo a ponte dissulfeto entre as cisteínas, apresentou uma ampla flutuação nas formações de folha- $\beta$ e turn; e nos 100 ns finais de simulação apresentou formação de $\alpha$-hélice na região do resíduo 101 e perda de conformação na região entre os resíduos 107-123.

No peptídeo DENV-1S, as cisteínas foram mutadas por serinas, removendo as pontes dissulfeto e, teoricamente, dando maior liberdade ao peptídeo. O mapa de estrutura secundária para o peptídeo DENV-1S mostra um perfil simétrico com estreitas faixas que formam estruturas $\beta$ ao longo da simulação. Além disso, uma intensa flutuação entre turn e ausência de estrutura se apresenta na porção central do peptídeo, resíduos 100-110.

Na sequência, o peptídeo DENV-3C é uma porção retirada da glicoproteína E do vírus do dengue tipo 3, com manutenção das cisteínas. A ponte dissulfeto entre as cisteínas forma uma faixa simétrica de estrutura do tipo $\beta$ ao longo da simulação. Entretanto, a faixa diminui sua espessura e resíduos vizinhos à esta faixa apresentam conformação turn. Em sua porção central apresentou uma faixa de formação turn com pequenas flutuações de hélice- $\alpha$ e folha- $\beta$.

Por fim, tivemos o peptídeo DENV-3S representando as mutações de cisteínas por serinas no peptídeo DENV-3C. Na ausência da ponte dissulfeto, o peptídeo manteve a formação de folha- $\beta$ ao longo da simulação com reduzida perda de conformação. Nas extremidades do peptídeo e na porção central, isto é, dentro da faixa de folha- $\beta$, os resíduos visitaram os espaços conformacionais correspondentes às conformações em $\alpha$-hélice, folha- 
$\beta$, turn e ausência de estrutura, com maior proporção para ausência de estrutura nessa região.

Além da estrutura secundária, verificamos a inserção do resíduo Trp (W101) na bicamada lipídica para todos os peptídeos. A escolha deste resíduo se deve ao fato de ser uma sonda fluorescente que altera seu máximo de emissão conforme o ambiente em que está localizada. Por esta razão experimentos de fluorescência e medidas de inserção do resíduo podem ser correlacionados.

Na Figura 38 são apresentados os resultados para inserção do Trp nas bicamadas lipídicas em função do tempo. É importante ressaltar que as linhas pontilhadas representam o posicionamento dos átomos de fósforo, e consequentemente, o valor médio para espessura da bicamada. O PFDEN apresentou uma leve inserção do resíduo, a partir dos 200 ns de simulação. Entretanto, ao final da simulação o resíduo estava posicionado fora da bicamada lipídica. Para os demais peptídeos, o Trp ficou posicionado fora das bicamadas lipídicas na maior parte das simulações.

Por fim, apresentamos na Figura 39 as imagens das simulações para os peptídeos virais da dengue na presença da bicamada lipídica mista de POPC/POPG (4/1). Nos snapshots representativos é possível compilar algumas informações obtidas pelas análises anteriores, tais como o posicionamento do peptídeo viral próximo à superfície da bicamada lipídica, que mantém a sua simetria ao longo da simulação. Além disso, os peptídeos virais não apresentam uma estrutura secundária definida, tendo em destaque o resíduo fluorescente Trp posicionado próximo à bicamada lipídica, sem, no entanto, adentrar na região das cadeias hidrofóbicas. 

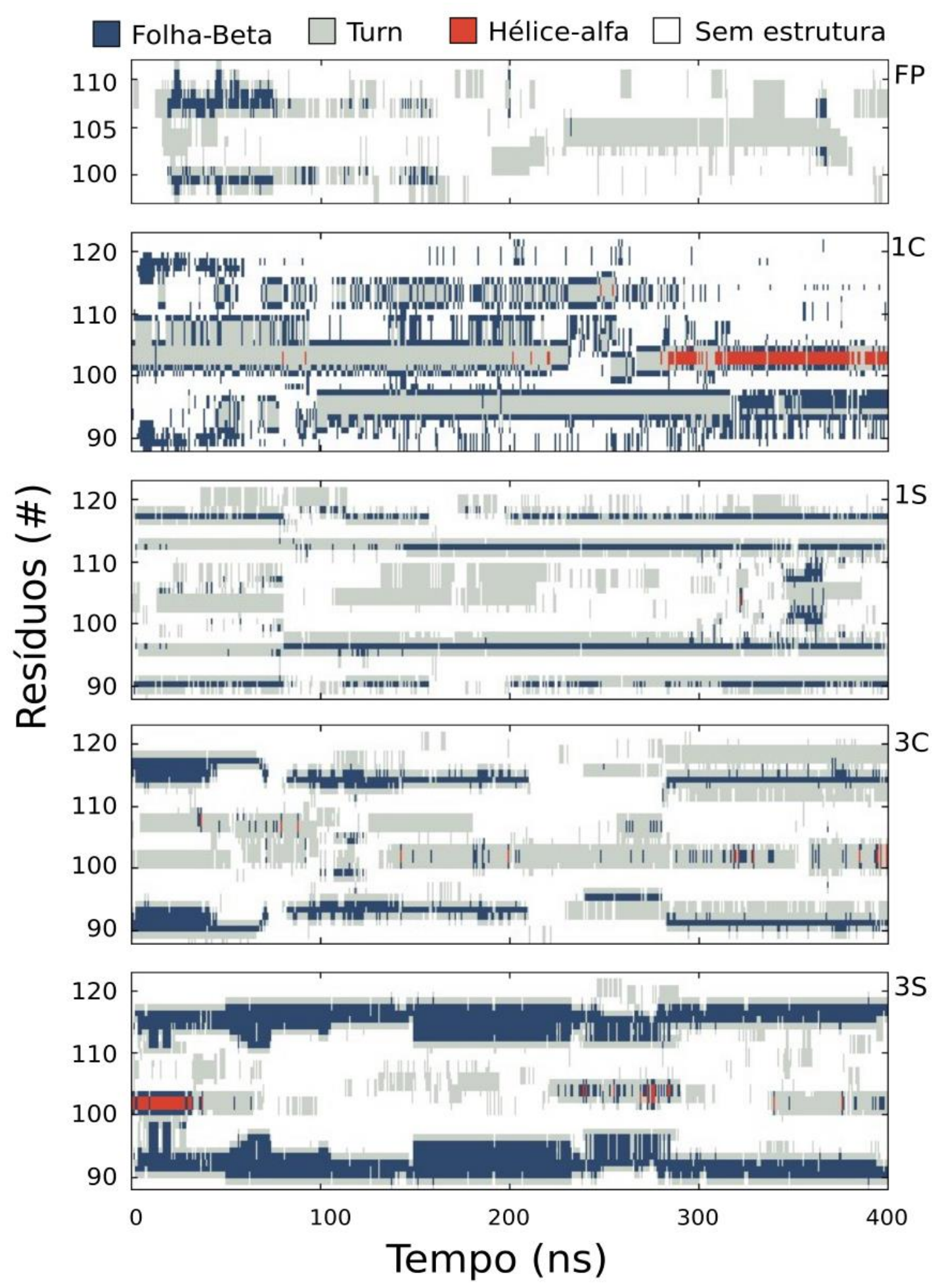

Figura 37 - Mapa da evolução temporal da estrutura secundária para os peptídeos virais. Figura elaborada por Danilo Olivier. 


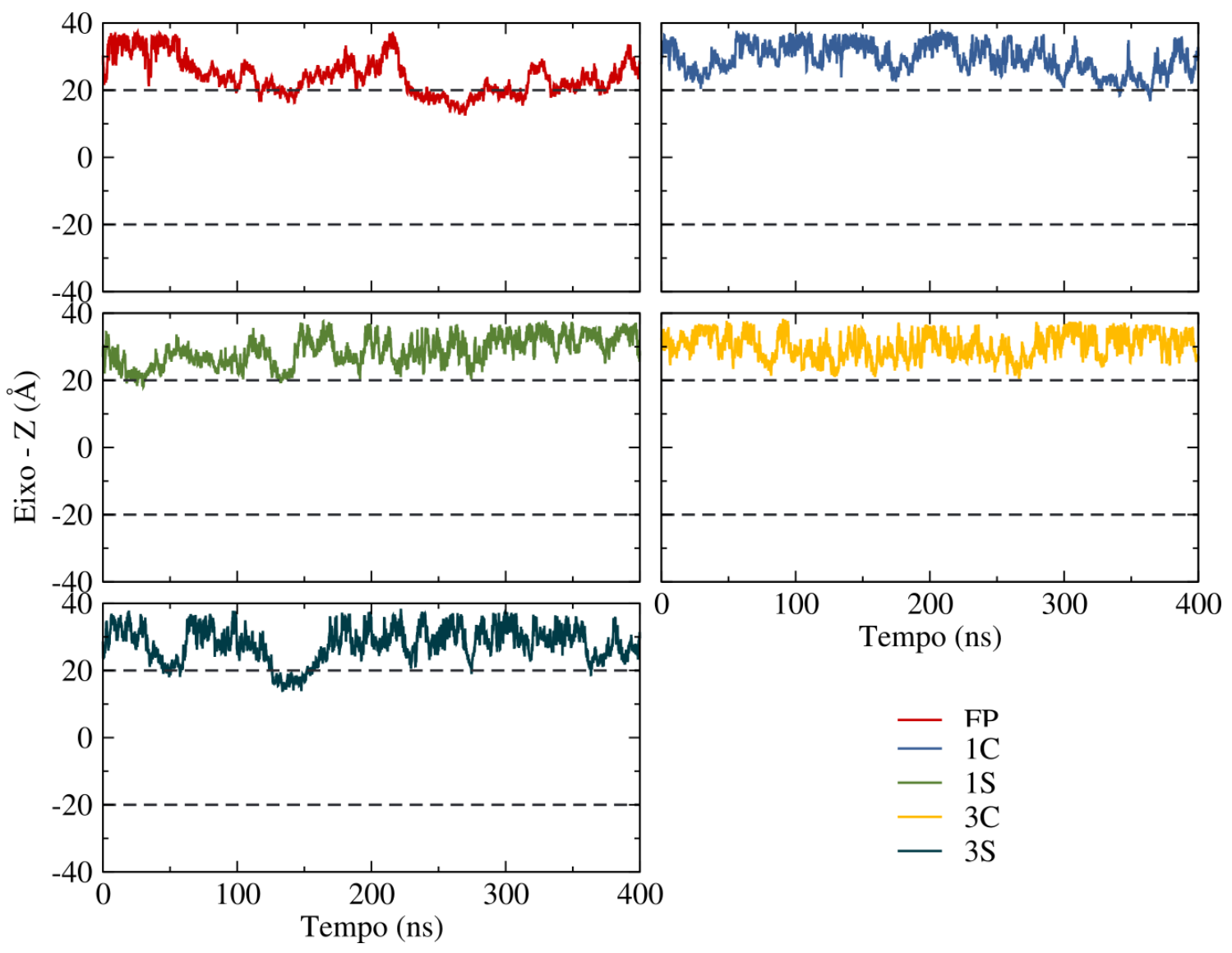

Figura 38 - Inserção do resíduo triptofano (W101) na bicamada lipídica ao longo da simulação. Figura elaborada por Danilo Olivier.

Dos resultados obtidos pela DM podemos afirmar que os peptídeos virais interagem com a bicamada lipídica de POPC/POPG. Entretanto, devido à sua constituição de aminoácidos, possuem pouca estabilidade em solvente ou na presença da bicamada lipídica, não sendo possível que o peptídeo induza mudanças estruturais tais como alteração na área por cabeça lipídica e espessura da bicamada. Estes resultados estão de acordo com dados experimentais citados na literatura para outros peptídeos virais da família dos Flavivírus e foram observados em nossos experimentos também, como no CD onde não observamos mudanças na conformação na presença das vesículas. 
A
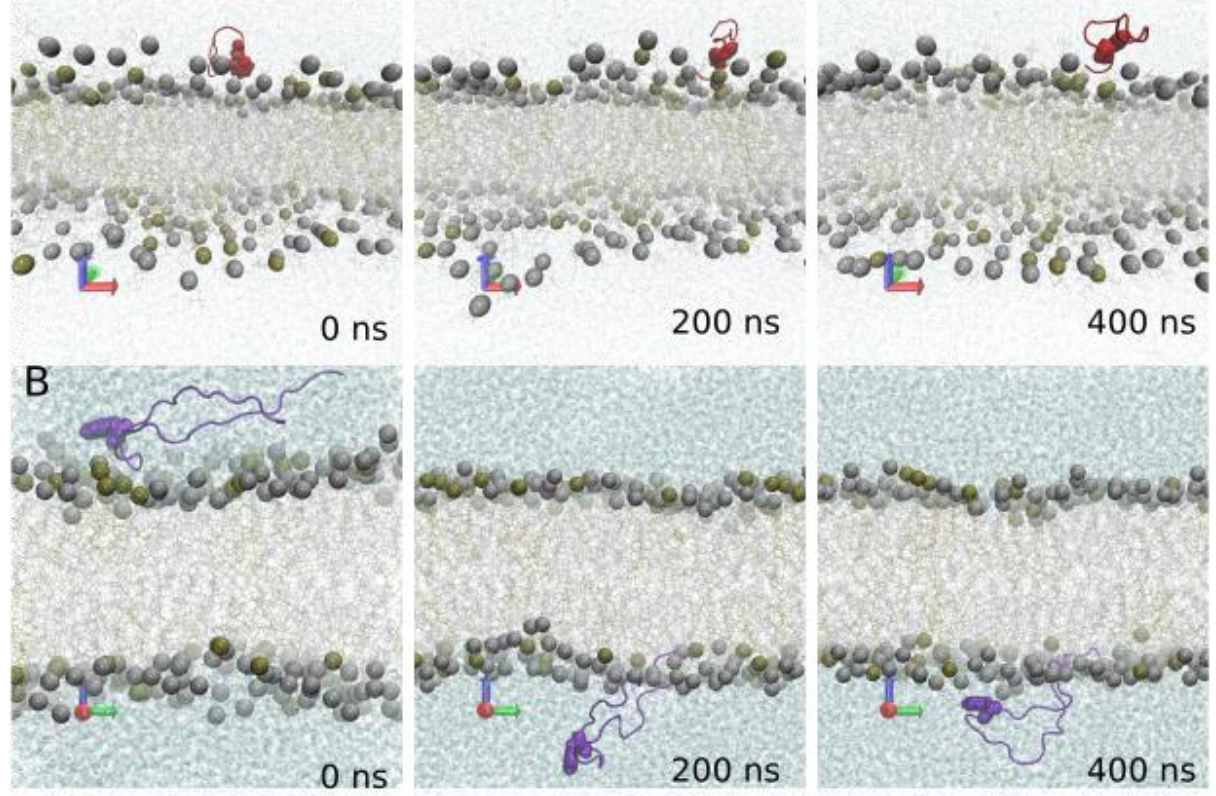

C
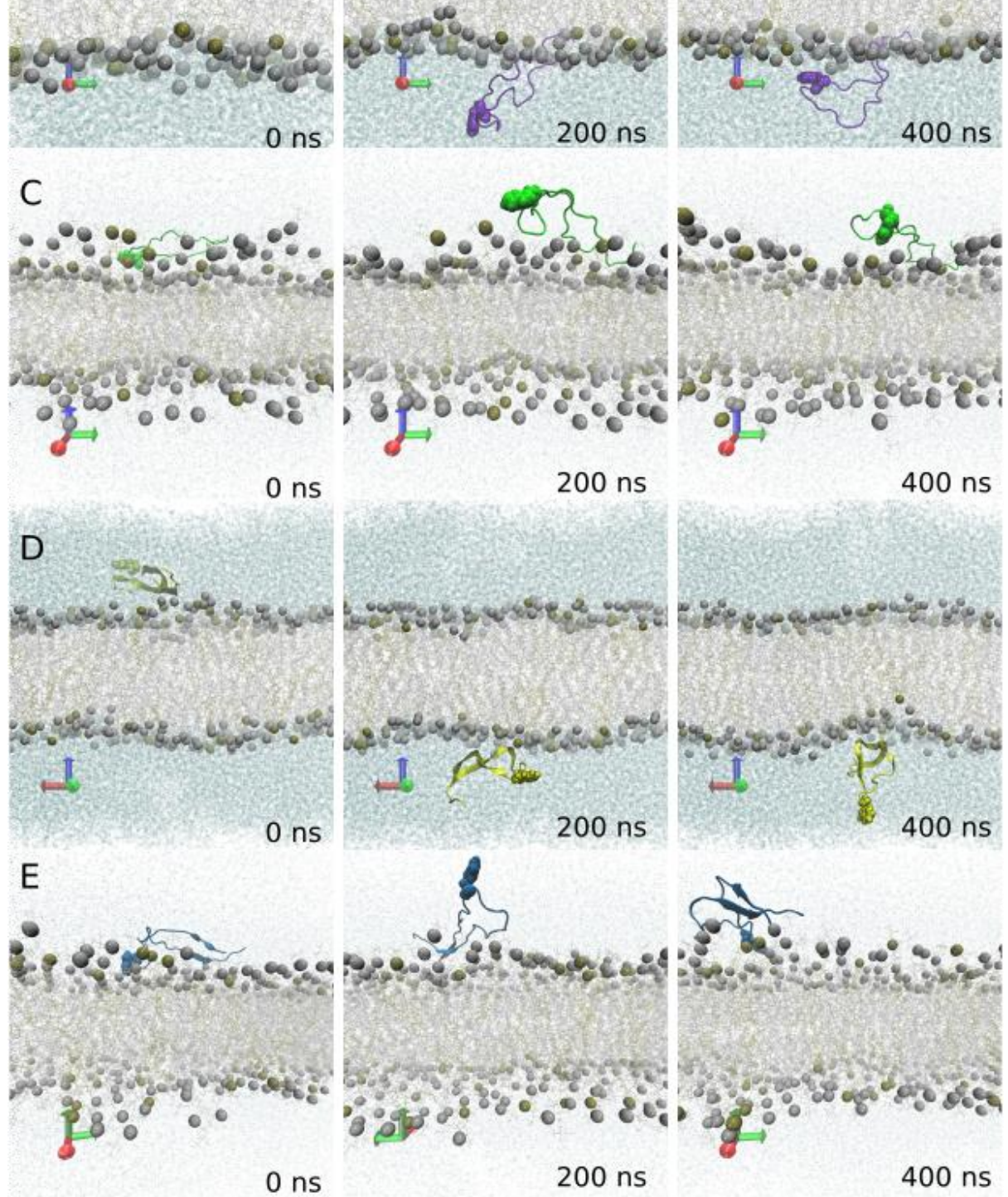

Figura 39 - Imagens representativas dos sistemas ao longo da simulação. A - PFDEN, B - DENV-1C, C -DENV1S, D - DENV-3C, E - DENV-3S. Figura elaborada por Danilo Olivier. 


\subsection{Complexos metálicos}

Nesta seção apresentamos os resultados experimentais obtidos a partir das medidas de DSC e RPE da interação dos complexos com a membrana modelo constituída pelos fosfolipídios DPPC, DPPG, POPC e POPG. São discutidos os efeitos dos complexos no comportamento termotrópico das vesículas a partir dos resultados dos estudos calorimétricos e dos resultados do estudo espectroscópico através de parâmetros empíricos obtido dos espectros de RPE.

\subsubsection{Calorimetria Diferencial de Varredura (DSC)}

Escolhemos duas composições lipídicas para o estudo da interação dos compostos com modelos de membrana: o DPPC, um fosfolipídio zwiteriônico, que representa um dos componentes lipídicos mais abundantes das membranas plasmáticas celulares e o DPPG, aniônico, que permite a comparação com o efeito na membrana superficialmente carregada negativamente, também comum em membranas celulares (123). Foi determinado o comportamento de fase dos lipossomos na ausência e na presença das moléculas de interesse.

$\mathrm{Na}$ Figura 40, temos os termogramas para o processo de transição de fase da bicamada lipídica constituída somente por DPPC e os respectivos parâmetros termodinâmicos, na ausência e na presença dos compostos, referentes à transição principal e à pré-transição, apresentados nas Tabelas 12 e 13, respectivamente. Variações na temperatura de transição de fase do lipídio podem indicar mudanças estruturais na bicamada, causadas pelos agentes externos. Bem como alterações na cooperatividade da transição e no empacotamento lipídico que podem ser observados através da mudança na entropia e/ou no formato da curva de transição. (115)

$\mathrm{Em} 35^{\circ} \mathrm{C}$, temos a temperatura de pré-transição do fosfolipídio DPPC puro, que surge da conversão da fase gel lamelar para a fase gel rippled, sendo uma transição menos energética e cooperativa que a transição principal, que corresponde à conversão da fase gel 
rippled para a fase lamelar líquido-cristalina, observada em $41^{\circ} \mathrm{C}$, concordando em boa aproximação com os dados da literatura. (124-126).

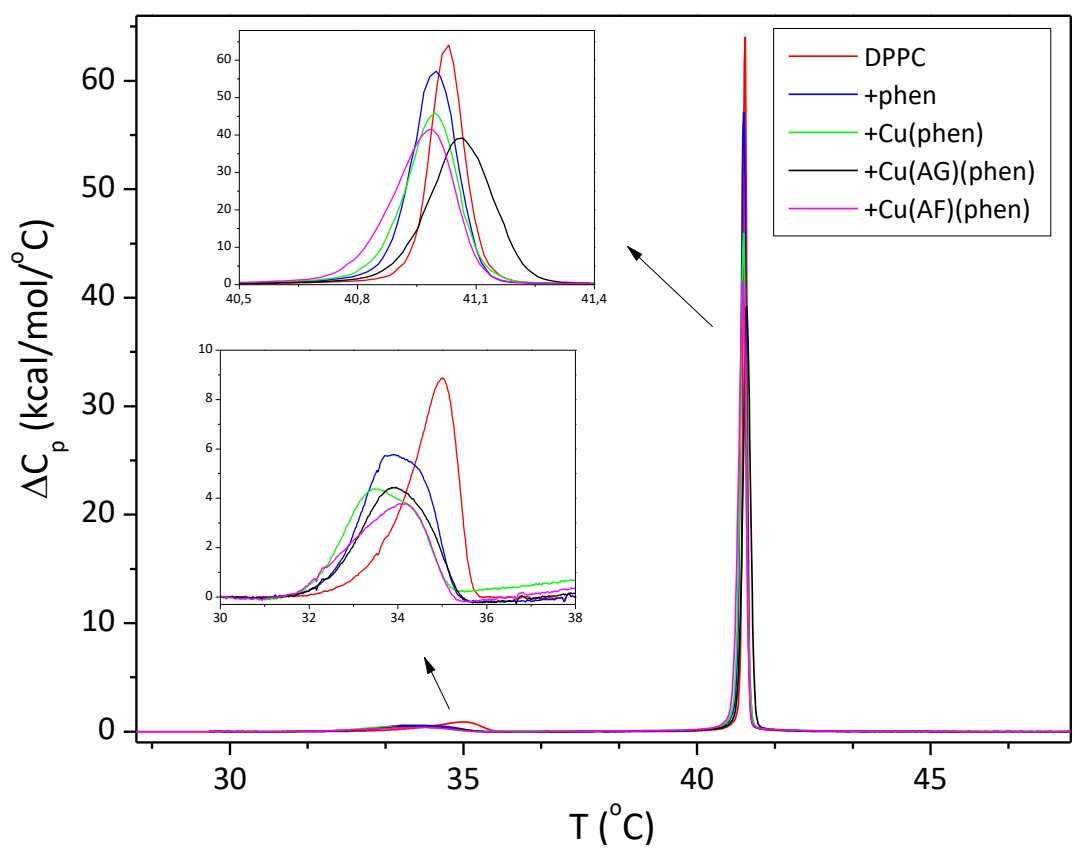

Figura 40 - Termogramas de DSC das MLVs de DPPC na ausência e na presença dos compostos. Figura elaborada pela autora.

Analisamos as alterações dos termogramas utilizando os perfis criados por Jain e $\mathrm{Wu}$ que determinam o tipo de perturbação causada e as possíveis localizações de diversos solutos em relação à bicamada de fosfolipídio a partir das alterações nos termogramas. (127) Com a adição dos compostos não houve uma mudança significativa nem na temperatura de transição, nem na largura do pico da transição principal do fosfolipídio neutro. Vemos apenas pequenas mudanças na entalpia calorimétrica, que podem indicar a ruptura das interações de van der Waals entre as cadeias carbônicas, o que leva a uma menor unidade cooperativa $\left(n_{M}\right)$, sugerindo que os compostos têm alguma capacidade de se intercalar entre as cadeias de ácidos graxos. (128) Dentre os diferentes compostos, aquele que leva às mudanças mais significativas é o $\mathrm{Cu}(\mathrm{AF})$ phen, provavelmente devido à presença do dipeptídeo contendo o aminoácido hidrofóbico fenilalanina. De forma geral, as poucas mudanças observadas na transição principal das vesículas de DPPC na presença dos 
compostos sugerem que tais compostos estão provavelmente localizados próximos à interface membrana-solvente.

Tabela 12 - Parâmetros termodinâmicos obtidos através da análise dos termogramas de DSC para a transição principal do fosfolipídio DPPC, na presença e na ausência dos compostos. Tabela elaborada pela autora.

\begin{tabular}{|c|c|c|c|c|c|}
\hline & $\begin{array}{l}\mathrm{T}_{\mathrm{M}} \\
\left({ }^{\circ} \mathrm{C}\right)\end{array}$ & $\begin{array}{c}\Delta \mathrm{T}_{1 / 2 \mathrm{M}} \\
\left({ }^{\circ} \mathrm{C}\right)\end{array}$ & $\begin{array}{c}\Delta H_{M} \\
\text { (kcal/mol) }\end{array}$ & $\begin{array}{c}\Delta \mathrm{S}_{\mathrm{M}} \\
\text { (cal/mol.K) }\end{array}$ & $\begin{array}{c}\mathrm{n}_{\mathrm{M}} \\
\left({ }^{\circ} \mathrm{C}^{-1}\right)\end{array}$ \\
\hline DPPC & 41,0 & 0,1 & 8,0 & 25,4 & 10,0 \\
\hline tphen & 41,0 & 0,1 & 9,2 & 29,1 & 7,1 \\
\hline$+\mathrm{Cu}($ phen) & 41,0 & 0,2 & 8,7 & 27,6 & 6,7 \\
\hline$+\mathrm{Cu}(\mathrm{AG})$ (phen) & 41,1 & 0,2 & 8,6 & 27,5 & 5,3 \\
\hline$+\mathrm{Cu}(\mathrm{AF})(\mathrm{phen})$ & 41,0 & 0,2 & 9,0 & 28,7 & 5,3 \\
\hline
\end{tabular}

Já na pré-transição temos alterações na temperatura de transição com a adição dos compostos que diminuem de 1 a $1,5^{\circ} \mathrm{C}$, com alargamento dos picos e a diminuição na variação de entalpia. Esta diminuição no valor de $\Delta \mathrm{H}$ resulta da modificação estrutural dos grupos da cabeça polar e sugere uma interação entre os peptídeos e os grupos cabeça do lipídio, (128) onde um perfil de transição caracteristicamente mais largo do que o perfil da transição da bicamada não modificada, sugere que os peptídeos estariam localizados entre os carbonos 2 e 8 da cadeia acila, o que concorda com o que foi descrito no parágrafo anterior sobre os efeitos na transição principal do DPPC. Mais uma vez, a cadeia lateral da fenilalanina parece ser determinante para as maiores alterações observadas nos valores de $T_{p}$ e cooperatividade.

A Figura 41 mostra os termogramas das vesículas multilamelares de DPPG e os efeitos dos compostos. Ao contrário da membrana neutra, o lipídio carregado negativamente apresentou mudanças substanciais quando da adição das moléculas de interesse. Não houve uma mudança significativa na $T_{M}$ da bicamada lipídica na presença da molécula de Fenantrolina sozinha. Já na presença dos complexos metálicos, há uma diminuição da temperatura, que podemos verificar na Tabela 14, onde são apresentados os dados termodinâmicos. 
Tabela 13 - Parâmetros termodinâmicos obtidos através da análise dos termogramas de DSC da pré-transição do fosfolipídio DPPC, na presença e na ausência dos compostos. Tabela elaborada pela autora.

\section{$\mathrm{T}_{\mathrm{P}}\left({ }^{\circ} \mathrm{C}\right) \quad \Delta \mathrm{T}_{1 / 2 \mathrm{P}}\left({ }^{\circ} \mathrm{C}\right) \quad \Delta \mathrm{H}_{\mathrm{P}}(\mathrm{kcal} / \mathrm{mol})$}

\begin{tabular}{cccc}
\hline DPPC & 35,0 & 1,2 & 1,2 \\
\hline +phen & 34,0 & 1,8 & 1,1 \\
\hline+ Cu(phen) & 33,5 & 2,0 & 0,9 \\
\hline$+\mathrm{Cu}(\mathrm{AG})$ (phen) & 34,1 & 1,9 & 0,8 \\
\hline$+\mathrm{Cu}(\mathrm{AF})$ (phen) & 33,7 & 2,1 & 0,7 \\
\hline
\end{tabular}

Na temperatura de $39,6^{\circ} \mathrm{C}$ é observada a transição de fase principal do DPPG, que está de acordo com a literatura. $(88,129)$ Na presença da molécula de Fenantrolina não houve mudanças significativas da $T_{M}$, aumentando a entalpia da transição, indicando uma maior interação de van der Waals. Já a incorporação dos complexos metálicos nas vesículas de DPPG é capaz de induzir mudanças no perfil da transição do lipídio. Observamos um deslocamento da temperatura de transição de fase principal para valores menores, cerca de $1{ }^{\circ} \mathrm{C}$ para todos os complexos, com um aumento da entropia da transição, indicando que houve uma diminuição no empacotamento global da fase gel, coerente com o perfil sugerido por Jain e Wu em que os compostos estão na região próxima ao centro da bicamada. Observamos também um aumento da largura desta transição, quando na presença de $\mathrm{Cu}($ phen), $\mathrm{Cu}(\mathrm{AF})($ phen) e $\mathrm{Cu}(\mathrm{AG})($ phen) sugerindo uma menor cooperatividade da transição, o que é consistente com a interação eletrostática entre a carga positiva do complexo e a superfície carregada negativamente da membrana. 


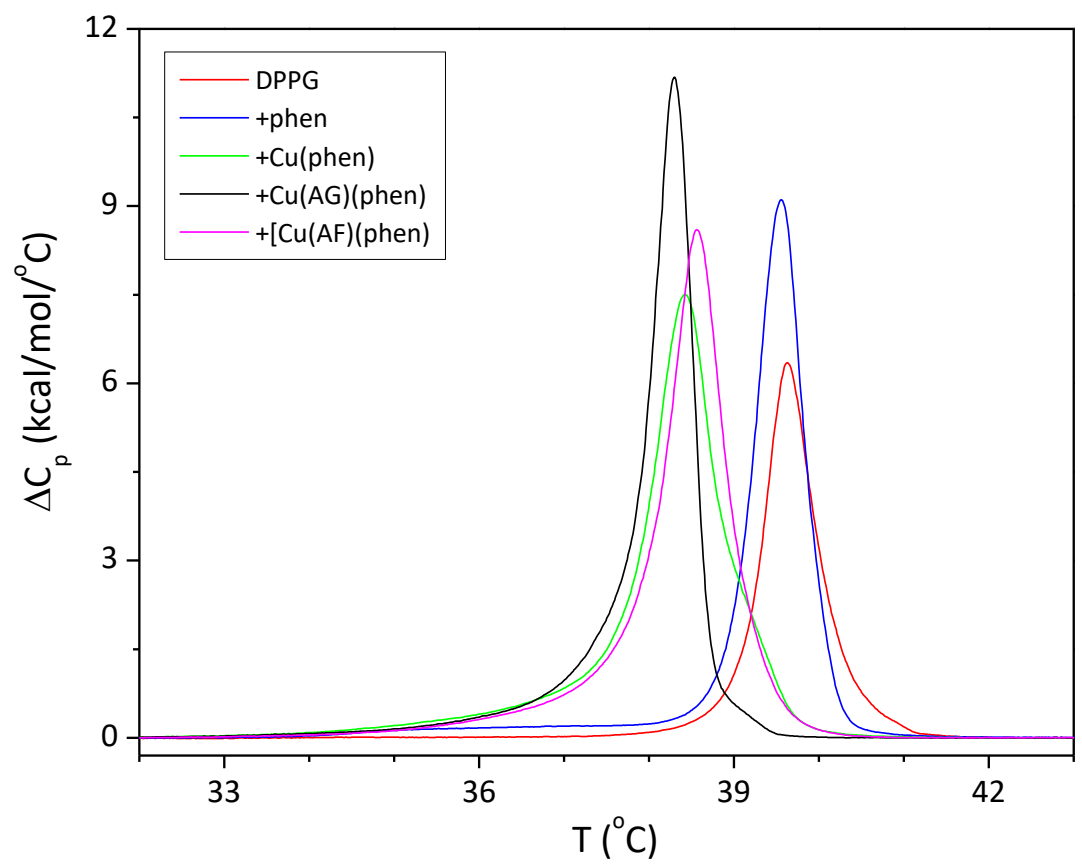

Figura 41 - Termograma das MLVs de DPPG na ausência e na presença dos compostos. Figura elaborada pela autora.

De maneira geral, analisando-se o conjunto de mudanças nos parâmetros termodinâmicos, os efeitos causados pelo composto contendo a fenilalanina parecem ser mais significativos, seguido pelo composto $\mathrm{Cu}($ phen). No caso do DPPG, percebemos claramente a relevância da adição do íon de Cu(II) para garantir a interação com o mimético de membrana e causar, por exemplo, a desestabilização da fase gel do DPPG (vista através da diminuição no valor de $T_{M}$ ), contribuindo para um efeito de fluidificação da membrana. A estratégia de incluir o íon $\mathrm{Cu}(\mathrm{II})$ se mostrou, portanto, relevante no que diz respeito à capacidade do composto em interagir com membranas negativas, o que também sugere que a interação eletrostática composto-membrana possa desempenhar um papel na seletividade de tal interação. 
Tabela 14 - Parâmetros termodinâmicos obtidos através da análise dos termogramas de DSC da transição principal do fosfolipídio DPPG na presença e na ausência dos compostos. Tabela elaborada pela autora.

\begin{tabular}{|c|c|c|c|c|c|}
\hline & $\begin{array}{l}\mathrm{T}_{\mathrm{M}} \\
\left({ }^{\circ} \mathrm{C}\right)\end{array}$ & $\begin{array}{c}\Delta \mathrm{T}_{1 / 2 \mathrm{M}} \\
\left({ }^{\circ} \mathrm{C}\right)\end{array}$ & $\begin{array}{c}\Delta \mathrm{H}_{\mathrm{M}} \\
(\mathrm{kcal} / \mathrm{mol})\end{array}$ & $\begin{array}{c}\Delta \mathrm{S}_{\mathrm{M}} \\
(\mathrm{cal} / \mathrm{mol} . \mathrm{K})\end{array}$ & $\begin{array}{c}\mathrm{n}_{\mathrm{M}} \\
\left({ }^{\circ} \mathrm{C}^{-1}\right)\end{array}$ \\
\hline DPPG & 39,6 & 0,6 & 5,8 & 18,4 & 1,6 \\
\hline tphen & 39,5 & 0,6 & 7,5 & 23,9 & 1,6 \\
\hline$+[\mathrm{Cu}(\text { phen })]^{2+}$ & 38,4 & 0,9 & 9,4 & 30,3 & 1,1 \\
\hline$+[\mathrm{Cu}(\mathrm{AG})($ phen $)]$ & 38,3 & 0,6 & 9,0 & 28,8 & 1,6 \\
\hline$+[\mathrm{Cu}(\mathrm{AF})($ phen $)]$ & 38,5 & 0,8 & 9,6 & 30,7 & 1,3 \\
\hline
\end{tabular}

\subsubsection{Análise dos parâmetros empíricos dos espectros de RPE}

A fim de obtermos informações agora em nível molecular acerca das interações entre os compostos e miméticos de membrana, foram realizadas medidas de RPE em lipossomos de DPPC, DPPG, POPC e POPG, contendo sondas, na ausência e na presença dos compostos de estudo. Os espectros medidos em cada caso estão no Apêndice a esta tese e a partir deles calculamos os parâmetros $A_{\text {máx }}$ e $h_{+1} / h_{0}$ segundo mostrados na Figura 12 da Seção 3.7.1. Os resultados obtidos para a variação desses parâmetros em função da temperatura estão mostrados nas Figuras 42-44.

Pela Figura 42 observamos que os compostos metálicos alteram discretamente os parâmetros relacionados à sonda 5-PCSL. Apesar de discretas, algumas mudanças são dignas de nota em face do que foi observado nos resultados de DSC: (1) em DPPC, as maiores mudanças advêm da presença de Cu(AG)phen (diminuição no valor de TM) e de Cu(AF)phen (diminuição na cooperatividade da transição); (2) em DPPG, os compostos contendo o metal $\mathrm{Cu}(\mathrm{II})$ causam os efeitos mais significativos, ainda que pequenos. 

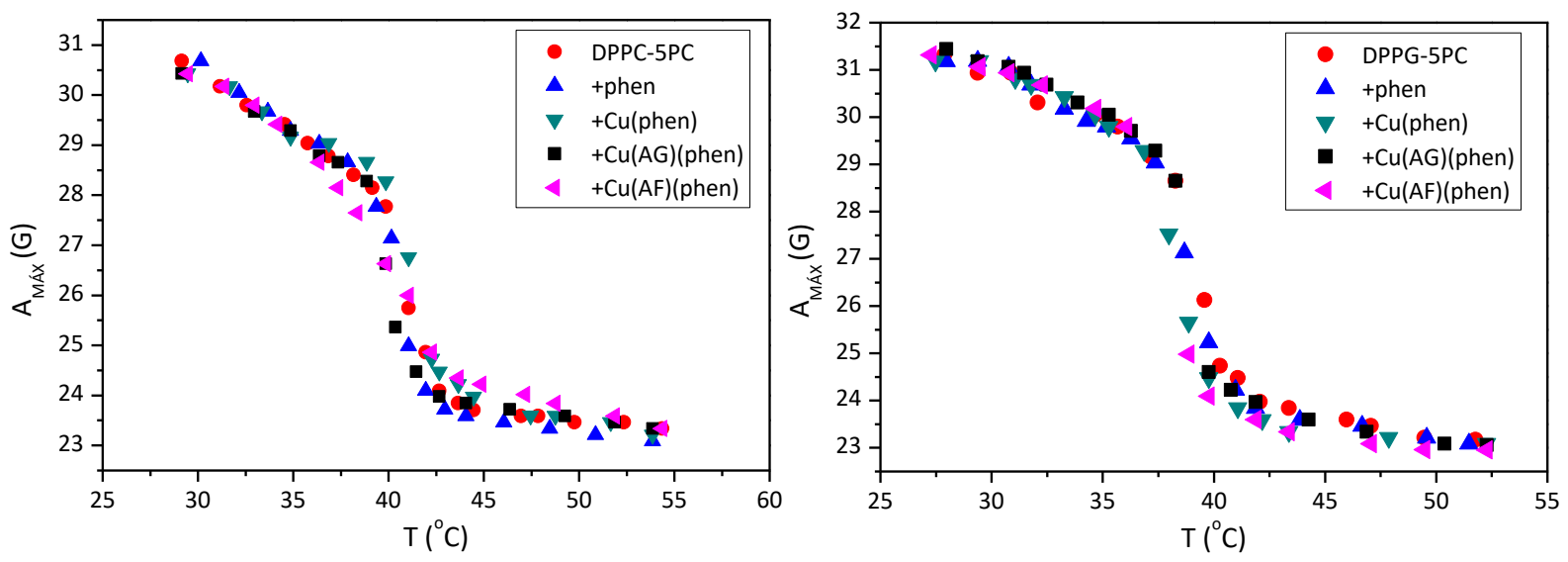

Figura 42 - Parâmetros $A_{\text {máx }}$ em função da temperatura para o marcador 5-PCSL em vesículas multilamelares (MLV) de DPPC e DPPG, na ausência e na presença dos compostos. Figura elaborada pela autora.

Já para a sonda 16-PCSL, posicionada no centro da bicamada, observamos que: (1) em DPPC, o único composto a induzir mudanças aparentes é, novamente, o Cu(AF)phen; (2) em DPPG, as temperaturas de transição monitoradas por RPE são um pouco diminuídas e vemos que os compostos contendo $\mathrm{Cu}(\mathrm{II})$ são capazes de aumentar a dinâmica da fase gel das vesículas, o que deve contribuir para o efeito de fluidificação da membrana observado pelos experimentos de DSC.

$\mathrm{Na}$ posição da cabeça polar das membranas, monitorada pela sonda DOPTC, observamos modificações parecidas em ambas as membranas, com efeitos mais discretos em DPPC do que em DPPG, onde podemos supor alguma relação com as cargas dos lipídios, PC neutra e PG carregada negativamente. Em DPPC, a alteração mais marcante vem da presença de $\mathrm{Cu}(\mathrm{II})(\mathrm{AG})$ phen (diminuição em $\mathrm{T}_{\mathrm{M}}$ ). Em DPPG, a molécula de Fenantrolina não muda o comportamento visto para a vesícula de DPPG, ao passo que os compostos contendo $\mathrm{Cu}$ (II) são capazes de diminuir a fluidez da membrana na região da cabeça polar de forma similar, provavelmente seu posicionamento nessa região da vesícula lipídica. 

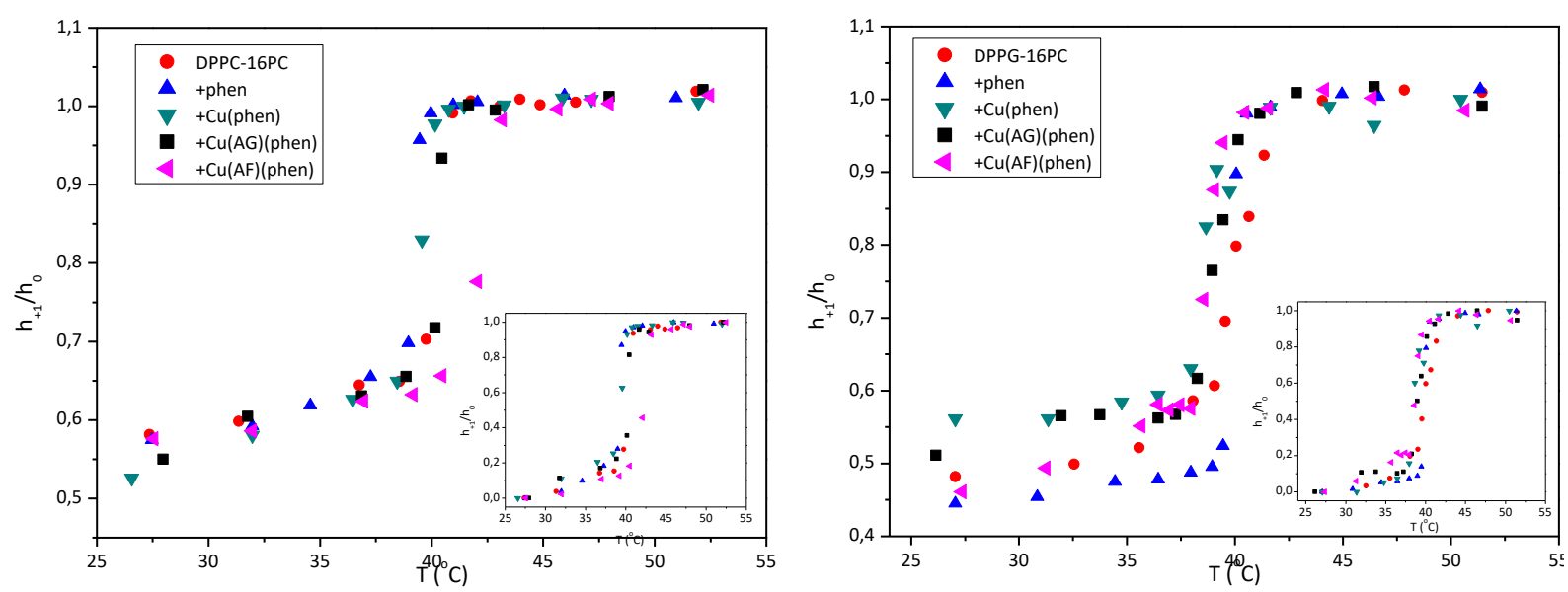

Figura 43 - Parâmetros $h_{+1} / h_{0}$ em função da temperatura para o marcador 16-PCSL em MLVs de DPPC e DPPG, na ausência e na presença dos compostos, onde o inset mostra os parâmetros normalizados. Figura elaborada pela autora.
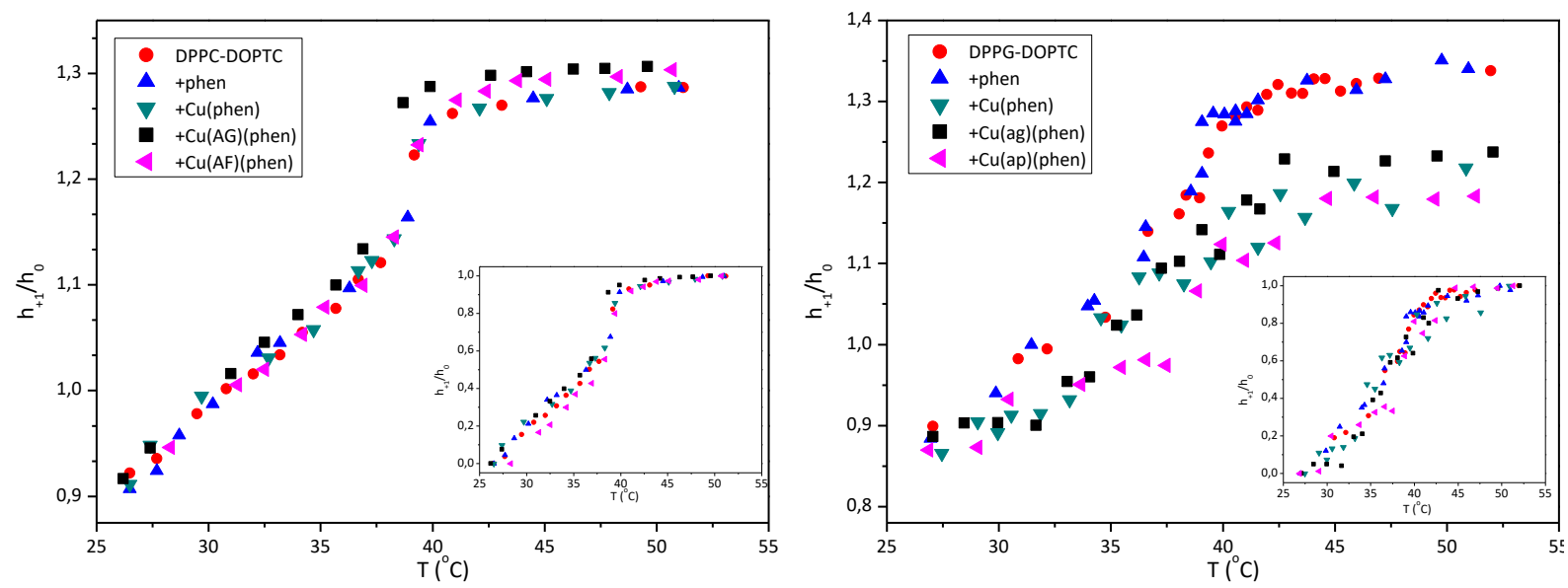

Figura 44 - Parâmetros $h_{+1} / h_{0}$ em função da temperatura para o marcador DOPTC em MLVs de DPPC e DPPG, na ausência e na presença dos compostos, onde 0 inset mostra os parâmetros normalizados. Figura elaborada pela autora.

Uma vez percebido que os complexos são capazes de alterar a temperatura de transição dos lipossomos de DPPC e DPPG e que tais alterações são vistas de forma mais clara na fase fluída (acima da temperatura de transição), decidimos investigar o efeito da presença dos compostos sobre a fase fluida em função da profundidade na bicamada. Para tanto, utilizamos lipossomos de PC e PG, formados por cadeias carbônicas insaturadas (POPC e POPG), que estão na fase fluida em temperatura ambiente, e contendo sondas magnéticas em diferentes posições ao longo dessas cadeias carbônicas $(5,7,10,12,14$ e 16) e também 
na cabeça do fosfolipídio. Os resultados obtidos para a variação desses parâmetros em função da temperatura estão mostrados nas Figuras 45 e 46.
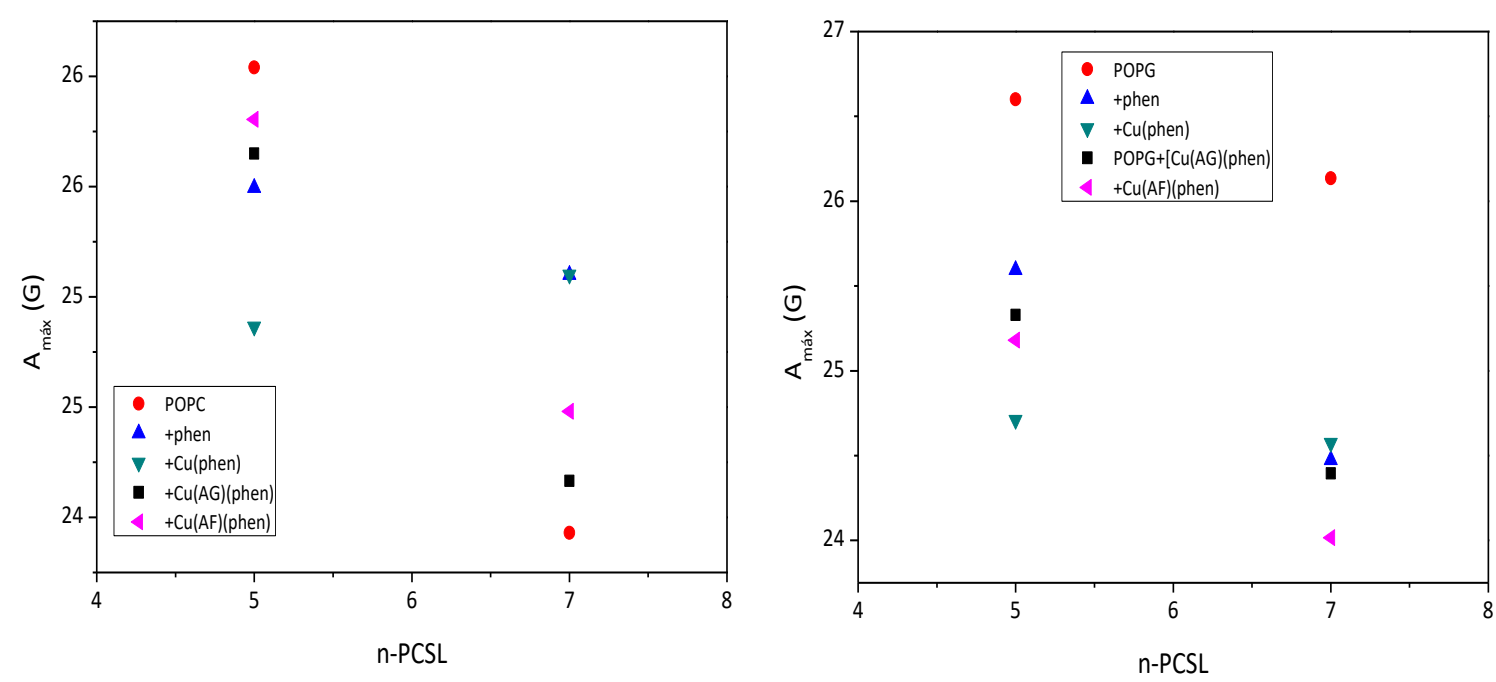

Figura 45 - Parâmetro Amáx para o marcador 5 e 7-PCSL em MLVs de POPC e POPG, na ausência e na presença dos compostos. As medidas foram realizadas a $25^{\circ} \mathrm{C}$, onde os dois miméticos de membrana estão na fase fluida. Figura elaborada pela autora.
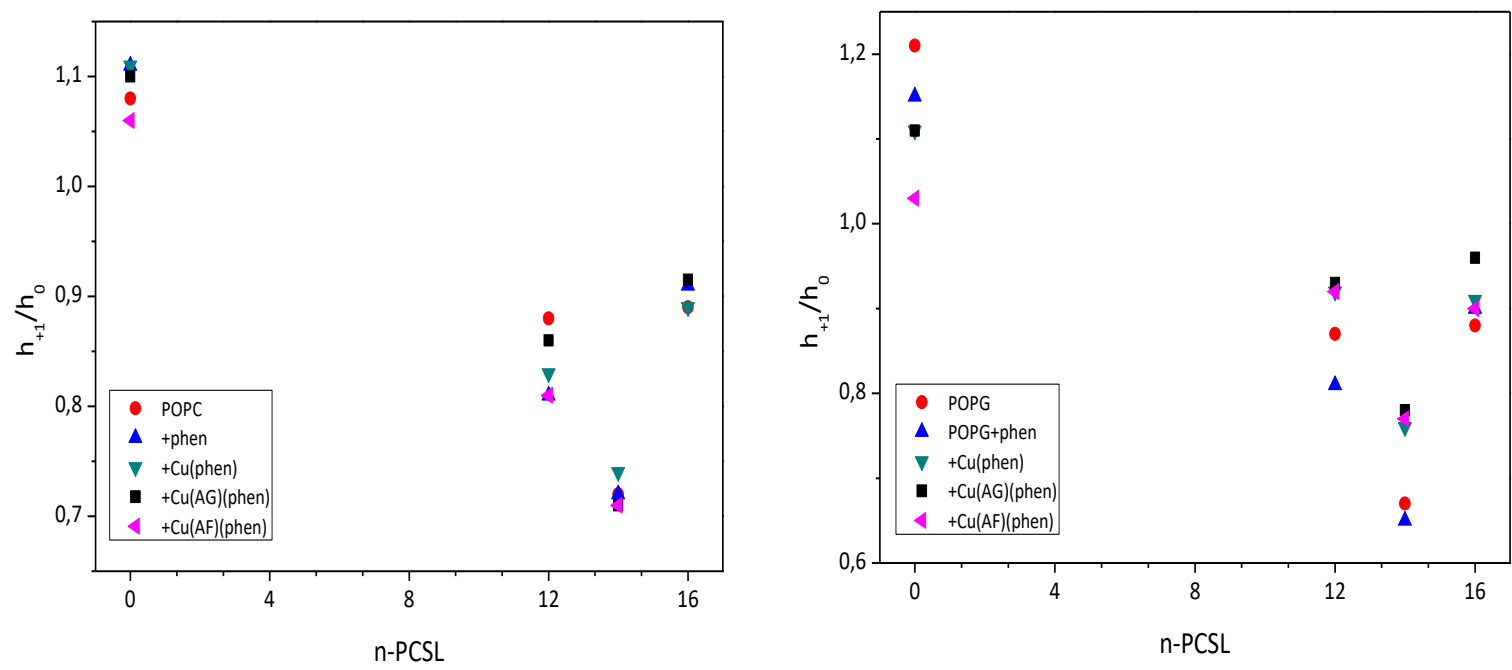

Figura 46 - Parâmetro $h_{+1} / h_{0}$ para os marcadores DOPTC (posição 0) e 10, 12, 14 e 16-PCSL em MLVs de POPC e POPG, na ausência e na presença dos compostos. As medidas foram realizadas a $25^{\circ} \mathrm{C}$, onde os dois miméticos de membrana estão na fase fluida. Figura elaborada pela autora. 
Avaliando agora ao longo de toda a cadeia acila e cabeça do fosfolipídio, porém apenas na fase fluida, observamos uma discreta interação na região mais superficial próxima à interface membrana-solvente, com as alterações nos parâmetros 5 e 7-PCSL para ambos os fosfolipídios, neutro e carregado, sendo um pouco maior para o segundo, o que concorda com as observações anteriores obtidas a partir dos dados de DSC e de RPE em função da temperatura. 


\section{Conclusões}

Este trabalho de doutorado teve como objetivo estudar a interação entre miméticos de membranas e dois grupos de pequenas moléculas de interesse biológico: o primeiro por estar ligado a uma doença, o peptídeo de fusão da Dengue, que é a parte da proteína viral que tem a função de "unir" a membrana viral com a do hospedeiro e assim ocorrer a replicação do vírus; o segundo grupo de moléculas, por estar relacionado a um potencial tratamento de doenças, sendo constituído por compostos de coordenação de cobre e Fenantrolina com dipeptídeos, Ala-Phe e Ala-Gly, potenciais candidatos a drogas antitumorais.

Nos estudos com o peptídeo de fusão, observamos a interação com vesículas de POPC/POPG (4/1), onde vimos que os peptídeos são capazes de induzir mistura lipídica em $\mathrm{pH}$ ácido, sendo maior para o DENV-1, e para os análogos contendo a ponte dissulfeto, com o mesmo perfil para a afinidade de ligação nas membranas, mostrando que a fusão está relacionada com a capacidade de se particionar na bicamada. Avaliamos também a emissão de fluorescência pelo resíduo de Trp, presente em todos os peptídeos, na ausência e na presença das vesículas e com o supressor de fluorescência acrilamida. Com isto, pudemos analisar a exposição do resíduo em solução e na presença das bicamadas; com esses dados pudemos supor que o PFDEN interage com a membrana em $\mathrm{pH} 5$, mudando a exposição do Trp na presença das vesículas. Já os resultados obtidos para os DENVs indicam que sua ligação à membrana não altera a exposição do Trp em pH 5; porém em pH 7,4, o DENV-1 interage com o lipídio alterando a exposição do Trp na presença do mesmo.

Nos experimentos de CD observamos que todos os peptídeos apresentam uma conformação desestruturada, mesmo na presença das vesículas, mas são capazes de se estruturar dependendo do meio em que estão, onde os peptídeos com a ponte dissulfeto estão mais "rígidos" e não conseguem adquirir o mesmo grau de estrutura que os análogos com a substituição por serina.

Dos experimentos de RPE podemos concluir que os peptídeos devam estar posicionados nas regiões próximas à interface da membrana-solvente, já que observamos 
apenas discretas mudanças em torno dos carbonos 5 e7 da cadeia hidrocarbônica; já com os peptídeos marcados, não observamos nenhuma mudança significativa na presença das vesículas. Estes dados corroboram o que foi observado em nossos experimentos de CD e fluorescência, ou seja, pouca ou nenhuma estruturação na presença das vesículas e pouca alteração da acessibilidade do resíduo de Trp ao solvente, indicando, de maneira geral, que os peptídeos são capazes de se particionar na membrana, mas adotam uma conformação não estruturada na superfície da vesícula lipídica.

A calorimetria entrou como mais uma técnica que corroborou os resultados anteriores, indicando que os peptídeos interagem com a bicamada, em ambos os pHs, com um efeito maior para o DENV-1C e PFDEN, onde parece que são capazes de homogeneizar a membrana no $\mathrm{pH}$ mais ácido.

Por fim, em relação aos peptídeos de fusão, as simulações por DM confirmaram nossos dados experimentais, onde observamos que os peptídeos interagem com a bicamada lipídica de POPC/POPG. Porém, de maneira geral, não induzem mudanças estruturais tais como alteração na área por cabeça lipídica e espessura da bicamada.

Estudos anteriores mostram que os peptídeos interferem na estrutura da bicamada lipídica e induzem fusão entre as vesículas, porém em menor porcentagem quando comparadas ao vírus completo, o que pode ser explicado pela diferença no tamanho do peptídeo comparado ao da glicoproteína completa, que supostamente tem outras regiões para auxiliar no processo da fusão, além de que o peptídeo sozinho não consegue manter a estrutura secundária com o loop como vimos nos experimentos de $\operatorname{CD}(130,131)$. Chegamos então a uma conclusão parecida com a de Torres e Bong sobre o peptídeo de fusão do vírus HIV, que supõem que a estrutura secundária de um peptídeo está relacionada à sua atividade de partição na membrana, onde um peptídeo desestruturado é energeticamente menos favorável em se inserir na membrana, podendo a baixa estruturação contribuir para a baixa mistura lipídica que obtivemos (110). O peptídeo PFDEN parece ter mais acessibilidade à membrana do que quando observamos o peptídeo de fusão com suas regiões flanqueadoras, sugerindo que quando inserido na glicoproteína E (ou seja, na presença das regiões flanqueadoras), o peptídeo não se insere totalmente na membrana, necessitando provavelmente de alguma outra mudança conformacional da proteína que catalise a interação. 
Dos estudos com os complexos metálicos observamos que todos são capazes de interagir com os miméticos de membrana. Entretanto, percebemos claramente que a inclusão do metal e dos dipeptídeos potencializa os efeitos observados. Aqui vale lembrar que a interação com membranas biológica é necessária para que tais moléculas alcancem seus destinos de ação nas células alvo e/ou sejam transportadas para entrega por veículos diversos.

Através dos experimentos de DSC e RPE observamos que a coordenação dos complexos com $\mathrm{Cu}(\mathrm{II})$ é relevante no que diz respeito à interação com as bicamadas negativas, supostamente devido à interação eletrostática, promovendo a seletividade na interação complexo-membrana.

Observamos nos experimentos de DSC que os complexos se intercalam na cadeia hidrocarbônica do lipídio zwiteriônico DPPC, estando mais próximos da interface membranasolvente, além de interagir com a cabeça do fosfolipídio o que pode ser relacionado com os dados de RPE, onde vemos uma maior mudança na bicamada com a adição dos complexos dipeptídicos. Já para o fosfolipídio DPPG observamos no DSC uma alteração maior com a adição dos complexos, que diminuem o empacotamento da fase gel, observado também nos experimentos de RPE, na região do centro da bicamada. Vemos um efeito oposto na cabeça polar, onde os complexos interagem de maneira a aumentar a estruturação na região.

Resumindo os efeitos dos complexos dipeptídicos nas bicamadas, podemos sugerir que $\mathrm{Cu}(\mathrm{AF})$ phen interage ao longo da bicamada acila do DPPC, com efeitos na interface membrana-solvente diminuindo a unidade cooperativa e no centro da bicamada, aumenta a dinâmica da fase gel. Já o $C u(A G)$ phen não adentra a bicamada, interagindo mais na superfície e cabeça polar. Para a bicamada carregada negativamente, vemos em geral uma maior mudança, onde ambos os complexos interagem na cabeça polar, tornando o ambiente mais empacotado, e ao longo da cadeia acila, tanto próximo a superfície, quanto no centro da bicamada aumentando a dinâmica da fase gel. 


\section{Bibliografia}

1. NELSON, D. L. AND COX, M. M. Lehninger Principles of Biochemistry. 4th. New York: W.H. Freeman and Company, 2005.

2. SINGER, S. J. AND NICOLSON, G. L. The Fluid Mosaic Model of the Structure of Cell Membranes. Science. 1972, Vol. 175, pp. 720-731.

3. ENGELMAN, D. M. Membranes are more mosaic than fluid. Nature. 2005, Vol. 438, pp. 578-580.

4. MOURTISEN, O. L. AND BLOOM, M. Matress model of lipid-protein interactiions in membranes. Biophysical Journal. 1984, Vol. 46, pp. 141-153.

5. MOURITSEN, O. G. Model Answers to Lipid Membrane Questions. Cold Spring Harbor Perspectives in Biology. 2011.

6. VEREB, G., et al. Dynamic, yet structured: The cell membrane three decades after the Singer-Nicolson model. Proceedings of the National Academy of Sciences of the United States of America. 2003, Vol. 100, 14, pp. 8053-8058.

7. PEETLA, C., STINE, A. AND LABHASETWAR, V. Biophysical Interactions with Model Lipid Membranes: Applications in Drug Discovery and Drug Delivery. Molecular Pharmaceutics. 2009, Vol. 6, 5, pp. 1264-1276.

8. LASIC, D. D. The mechanism of vesicle formation. Biochemistry Journal. 1988, Vol. 256, pp. 1-11.

9. AVANTI POLAR LIPIDS. Avanti Polar Lipids. Alabaster, Alabama, USA : Avanti Polar Lipids, Inc.

10. MERRIFIELD, R. B. Solid Phase Peptide Synthesis. I. The Synthesis of a Tetrapeptide. Journal of the American Chemical Society. 1963, Vol. 85, 14, pp. 2149-2154. 
11. ATHerton, E. AND ShepPARD, R. C. Solid Phase Peptide Synthesis: A Practical Approach. Oxford : IRL Press at Oxford University Press, 1989.

12. KAISER, E., et al. Color Test for Detection of Free Terminal Amino Groups in the Solid-Phase Synthesis of Peptides. 1970, Analytical Biochemistry, Vol. 34, pp. 595-598.

13. IGLESIAS, S., et al. Synthesis, structural characterization and cytotoxic activity of ternary copper(II)-dipeptide-phenanthroline complexes. A step towards the development of new copper compounds for the treatment of cancer. Journal of Inorganic Biochemistry. 2014, Vol. 139, pp. 117-123.

14. VIOSSAT, B., et al. Crystal structure of bis( $\mu$-chloro)bis[chloro-(o-phenanthtroline$\left.\mathrm{N}, \mathrm{N}^{\prime}\right)$-copper(II)], Cu2(C12H8N2)2(Cl2)2. Zeitschrift fur Kristallographie - New Crystal Structures. 1998, Vol. 213, pp. 329-330.

15. MARTIN, S. R. AND SCHILSTRA, M. J. Circular Dichroism and Its Application to the Study of Biomolecules. Methods in Cell Biology. 2008, Vol. 84, pp. 263-293.

16. KELLY, S. M., JESS, T. J. AND PRICE, N. C. How to study proteins by circular dichroism. Biochimica et Biophysica Acta. 2005, Vol. 1751, pp. 119-139.

17. LEES, J. G., et al. CDtool-an integrated software package for circular dichroism spectroscopic data processing, analysis, and archiving. Analytical Biochemistry. 2004, Vol. 332,2 , pp. 285-289.

18. MILES, A. J. AND WALLACE, B. A. CDtoolX, a Downloadable Software Package for Processing and Analyses of Circular Dichroism Spectroscopic Data. Protein Science. 2018.

19. FORSTER, T. Transfer mechanisms of electronic excitation. Discussion of the Faraday Society. 1959, Vol. 27, pp. 7-17.

20. STRUCK, D. K., HOEKSTRA, D. AND PAGANO, R. E. Use of Resonance Energy Transfer To Monitor Membrane Fusion. American Chemical Society. 1981, Vol. 20, pp. 40934099. 
21. MAIER, O., OBERLE, V. AND HOEKSTRA, D. Fluorescent lipid probes: some properties and applications (a review). Chemistry and Physics of Lipids. 2002, Vol. 116, pp. 3-18.

22. LAKOWICZ, J. R. Principles of Fluorescence Spectroscopy. 3. New York : Springer US, 2006.

23. LADOKHIN, A. S. Fluorescence Spectroscopy in Peptide and Protein Analysis. [book auth.] R.A. Meyers. Encyclopedia of Analytical Chemistry. Chichester : John Wiley \& Sons Ltd., 2000, pp. 5762-5779.

24. SANTOS, N. C., PRIETO, M. AND CASTANHO, A. R. B. Quantifying molecular partition into model systems of biomembranes: an emphasis on optical spectroscopic methods. Biochimica et Biophysica Acta. 2003, Vol. 1612, pp. 123- 135.

25. BUSHUEVA, T. L., BUSEL, E. P. AND BURSTEIN, E. A. Some Regularities of Dynamic Accessibility of Buried Fluorescent Residues to External Quenchers in Proteins. Archives of Biochemistry and Biophysics. 1980, Vol. 204, 1, pp. 161-166.

26. MCELHANEY, R. N. The use of differential scanning calorimetry and differential thermal analysis in studies of model and biological membranes. Chemistry and Physics of Lipids. 1982, Vol. 30, pp. 229-259.

27. CARRER, D. C. AND MAGGIO, B. Phase behavior and molecular interactions in mixtures of ceramide with dipalmitoylphosphatidylcholine. Journals of Lipid Research. 1999, Vol. 40, pp. 1978-1989.

28. PERUSSI, J. R., RUGGIERO, A. C. AND TABAK, M. O método de marcadores de spin aplicado a bioquímica. Química Nova. 1985, pp. 313-324.

29. AXEL, F. S. Biophysics with Nitroxyl Radicals. Biophysics of Structure and Mechanism. 1976, Vol. 2, pp. 181-218. 
30. SCHNEIDER, D. J. AND FREED, J. H. Calculating slow motional magnetic resonance spectra: a user's guide. [book auth.] L. J. BERLINER AND J. REUBEN. Biological magnetic resonance. New York: Plenum Publishing, 1989, Vol. 8, pp. 1-76.

31. BASSO, L. G. M., MENDES, L. F. S. AND COSTA-FILHO, A. J. The two sides of a lipidprotein story. Biophysical Reviews. 2016, Vol. 8, pp. 179-191.

32. CESPEDES, G. F. Sínteses e Estudos dos Diferentes Peptídeos de Fusão dos Flavivirus causadores da Dengue. Instituto de Química - Campus Araraquara, UNESP. Araraquara : s.n., 2013. Tese de Doutorado.

33. STAUFFER, F., et al. Interaction between dengue virus fusion peptide and lipid bilayers. Molecular Membrane Biology. 2008, Vol. 25, 2, pp. 128-138.

34. SAHU, I.. D. AND LORIGAN, G. A. Site-Directed Spin Labeling EPR for Studying Membrane Proteins. BioMed Research International. Vol. 2018, p. 3248289.

35. HALLET, F. R. Particle size analysis by dynamic light scattering. Food Research International. 1994, Vol. 27, pp. 195-198.

36. EDWARD, J. T. Molecular Volumes and the Stokes-Einstein Equation. Journal of Chemical Education. 1970, Vol. 47, 4, pp. 261-270.

37. STETEFELD, J., MCKENNA, S. A. AND PATEL, T. R. Dynamic light scattering: a practical guide and applications in biomedical sciences. Biophysical Reviews. 2016, Vol. 8, pp. 409-427.

38. PORASSO, R. D. AND CASCALES, J. J. L. A criterion to identify the equilibration time in lipid bilayer simulations. Papers in Physics. 2012, Vol. 4, p. 040005.

39. PHILLIPS, J. C., et al. Scalable molecular dynamics with NAMD. Journal of Computational Chemistry. 2005, Vol. 26, 16, pp. 1781-1802. 
40. KLAUDA, J. B., et al. Update of the CHARMM All-Atom Additive Force Field for Lipids: Validation on Six Lipid Types. Journal of Physical Chemistry B. 2010, Vol. 114, pp. 7830-7843.

41. SAPAY, N. AND TIELEMAN, D. P. Combination of the CHARMM27 force field with united-atom lipid force fields. Journal of Computational Chemistry. 2010.

42. HUMPHREY, W., DALKE, A. AND SCHULTEN, K. VMD: Visual Molecular Dynamics. Journal of Molecular Graphics. 1996, Vol. 14, 1, pp. 33-38.

43. WHO. Ebola virus disease. WHO. [Online] World Health Organization, 02 12, 2018. [Cited: 08 23, 2018.] http://www.who.int/news-room/fact-sheets/detail/ebola-virus-disease.

44. GYAWALI, N., BRADBURY, R. S. AND TAYLOR-ROBINSON, A. W. The global spread of Zika virus: is public and media concern justified in regions currently unaffected? Infectious Diseases of Poverty. 2016, Vol. 5, p. 37.

45. WHO. Yellow fever - Brazil. WHO. [Online] World Health Organization, 02 27, 2018. [Cited: 08 23, 2018.] http://www.who.int/csr/don/27-february-2018-yellow-feverbrazil/en/.

46. GUZMAN, M. G. AND HARRIS, E. Dengue. Lancet. 2015, Vol. 385, pp. 453-465.

47. SHEPARD, D. S., et al. Economic Impact of Dengue Illness in the Americas. The American Society of Tropical Medicine and Hygiene. 2011, Vol. 54, 2, pp. 200-207.

48. CLARO, L. B. L., TOMASSINI, H. C. B. AND ROSA, M. L. G. Prevenção e controle do dengue: uma revisão de estudos sobre conhecimentos, crenças e práticas da população. Cadernos de Saúde Pública. 2004, Vol. 20, 6, pp. 1447-1457.

49. BACK, A. T. AND LUNDKVIST, A. Dengue viruses - an overview. Infection Ecology \& Epidemiology. 2013, Vol. 3, p. 19839. 
50. DEJNIRATTISAI, W., et al. A new class of highly potent, broadly neutralizing antibodies isolated from viremic patients infected with dengue virus. Nature Immunology. 2015, Vol. 16, pp. 170-177.

51. NORMILE, D. Surprising New Dengue Virus Throws A Spanner in Disease Control Efforts.. 2013, Science, Vol. 342.

52. MUSTAFA, M. S., et al. Discovery of fifth serotype of dengue virus (DENV-5): A new public health dilemma in dengue control. Medical Journal Armed Forces India. 2015, Vol. 71, pp. 67-70.

53. KYLE, J. L. AND HARRIS, E. Global Spread and Persistence of Dengue. The Annual Review of Microbiology. 2008, Vol. 62, pp. 71-92.

54. WORLD HEALTH ORGANIZATION. Dengue: Guidelines for Diagnosis, Treatment, Prevention and Control. Geneva : WHO, 2009.

55. KOURI, G. P., et al. Dengue haemorrhagic fever/dengue shock syndrome: lessons from the Cuban epidemic, 1981. 1989, Bulletin of the World Health Organization, Vol. 67, pp. $375-380$.

56. ALVAREZ, M., et al. Dengue hemorrhagic fever caused by sequential Dengue 1-3 Virus infections over a long time interval: Havana epidemic, 2001-2002. 6, 2006, The American Journal of Tropical Medicine and Hygiene, Vol. 75, pp. 1113-1117.

57. SIMMONS, C. P., et al. Recent advances in dengue pathogenesis and clinical management. Vaccine. 2015, Vol. 33, pp. 7061-7068.

58. ACHEE, N. L. , et al. A Critical Assessment of Vector Control for Dengue Prevention. Plos Negleted Tropical Diseases. 2015, Vol. 9, 5, p. e0003655.

59. CAPEDING, M. R., et al. Clinical efficacy and safety of a novel tetravalent dengue vaccine in healthy children in Asia: a phase 3, randomised, observer-masked, placebocontrolled trial. The Lancet. 2014, Vol. 384, 9951, pp. 1358-1365. 
60. VILLAR, L., et al. Efficacy of a tetravalent dengue vaccine in children in Latin America. The New England Journal of Medicine. 2015, Vol. 372, pp. 113-123.

61. SANOFI. Dengvaxia ${ }^{\circledR}$ : Protective value for people with at least one prior dengue infection confirmed; vaccinating people without prior infection not recommended. [Online] 06 14, 2018. [Cited: 08 23, 2018.] https://mediaroom.sanofi.com/en/articles/2018/sanofipasteur-communication-on-the-new-england-journal-of-medicine-article/.

62. MUKHOPADHYAY, S., KUHN, R. J. AND ROSSMANN, M. G. A structural perspective of the Flavivirus life cycle. Nature Reviews Microbiology. 2005, Vol. 3, pp. 13-22.

63. KEELAPANG, P., et al. Alterations of pr-M Cleavage and Virus Export in pr-M Junction Chimeric Dengue Viruses. Journal of Virology. 2004, Vol. 78, 5, pp. 2367-2381.

64. KUHN, R. J., et al. Structure of Dengue Virus: Implications for Flavivirus Organization, Maturation, and Fusion. Cell. 2002, pp. 717-725.

65. PERERA, R. AND KUHN, R. J. Structural Proteomics of Dengue Virus. Current Opinion in Microbiology. 2008, Vol. 11, 4, pp. 369-377.

66. Dengue viruses. Nature Education. 2011.

67. TAMM, L. K. , et al. Structure and Function of Membrane Fusion Peptides. Biopolymers (Peptide Science). 2002, Vol. 66, pp. 249-260.

68. SELIGMAN, S. J. Constancy and diversity in the flavivirus fusion peptide. Virology Journal. 2008, Vol. 5, 27.

69. MENDES, Y. S., et al. The Structural Dynamics of the Flavivirus Fusion PeptideMembrane Interaction. Plos One. 2012, Vol. 7 (10), p. e47596.

70. MODIS, Y., et al. Structure of the dengue virus envelope protein after membrane fusion. Nature. 2004, Vol. 427, pp. 313-319. 
71. ROEHRIG, J. T., et al. Synthetic Peptides Derived from the Deduced Amino Acid Sequence of the E-Glycoprotein of Murray Valley Encephalitis Virus Elicit Antiviral Antibody. Virology. 1989, Vol. 171, pp. 49-60.

72. ROEHRIG, J. I. , et al. Antibodies to Dengue 2 virus E-glycoprotein synthetic peptides indentify antigenic conformation. Virology. 1990, Vol. 177, pp. 668-675.

73. LEDIZET, M., et al. Antibodies targeting linear determinants of the envelope protein protect mice against West Nile virus. The Journal of Infectious Diseases. 2007, Vol. 196, pp. 1741-1748.

74. ROGERS, D. M., KENT, M. S. AND REMPE, S. B. Molecular basis of endosomalmembrane association for the dengue virus envelope protein. Biochimica et Biophysica Acta. 2015, Vol. 1848, pp. 1041-1052.

75. MODIS, Y., et al. Variable Surface Epitopes in the Crystal Structure of Dengue Virus Type 3 Envelope Glycoprotein. Journal of Virology. 2005, Vol. 79, 2, pp. 1223-1231.

76. OLIVIER, D. DA SILVA. Interação entre peptídeos de fusão da dengue e membranas modelo: uma visão experimental e computacional. Departamento de Física Faculdade de Filosofia, Ciências e Letras de Ribeirão Preto, USP. Ribeirão Preto : s.n., 2016. Tese de Doutorado.

77. ROGERS, D. M., KENT, M. S. AND REMPE, S. B. Molecular basis of endosomalmembrane association for the dengue virus envelope protein. Biochimica et Biophysica Acta. 2015, Vol. 1848, pp. 1041-1052.

78. UMASHANKAR, M., et al. Differential Cholesterol Binding by Class II Fusion Proteins Determines Membrane Fusion Properties. Journal of Virology. 2008, Vol. 82, 18, pp. 9245-9253.

79. ZAITSEVA, E., et al. Dengue Virus Ensures Its Fusion in Late Endosomes Using Compartment-Specific Lipids. Plos Pathogens. 2010, Vol. 6, p. e100113. 
80. TORRES, O. AND BONG, D. Determinants of Membrane Activity from Mutational Analysis of the HIV Fusion Peptide. Biochemistry including biophysical chemistry \& molecular biology. 2011, Vol. 50, pp. 5195-5206.

81. Protein Calculator v3.4. Protein Calculator v3.4. [Online] 05 13, 2013. [Cited: 07 20, 2018.] http://protcalc.sourceforge.net/.

82. MODIS, Y., et al. Structure of the Dengue virus envelope protein after membrane fusion. Nature. 2004, Vol. 427, pp. 313-319.

83. GOPAL, R., et al. Applications of Circular Dichroism for Structural Analysis of Gelatin and Antimicrobial Peptides. International Journal of Molecular Sciences. 2012, Vol. 13, pp. 3229-3244.

84. SONNICHSEN, F. D., et al. Effect of Trifluoroethanol on Protein Secondary Structure: An NMR and CD Study Using a Synthetic Actin Peptide. Biochemistry. 1992, Vol. 31, pp. $8790-8798$.

85. SACKETT, K., TERBUSH, A. AND WELIKY, D. P. HIV gp41 six-helix bundle constructs induce rapid vesicle fusion at $\mathrm{pH} 3.5$ and little fusion at $\mathrm{pH}$ 7.0: understanding $\mathrm{pH}$ dependence of protein aggregation, membrane binding, and electrostatics, and implications for HIV-host cell fusion. European Biophysics Journal. 2011, Vol. 40, pp. 489-502.

86. LORINCZY, D., KISS, M. AND BELAGYI, J. DSC and EPR study on AMP.PNP, BEFX and AlF4 containing myiosin nucleotide complexes. Journal of Thermal Analysis and Calorimetry. 2003, Vol. 72, pp. 565-572.

87. BARROSO, R. P., BASSO, L. G. M. AND COSTA-FILHO, A. J. Interactions of the antimalarial amodiaquine with lipid model membranes. Chemistry and Physics of Lipids. 2015, Vol. 186, pp. 68-78.

88. GORDON, V. D., et al. Lipid organization and the morphology of solid-like domains in phase-separating binary lipid membranes. Journal of Physics: Condensed Matter. 2006, Vol. 18, pp. L415-L420. 
89. SEVCSIK, E., et al. Interaction of LL-37 with Model Membrane Systems of Different Complexity: Influence of the Lipid Matrix. Biophysical Journal. 2008, pp. 4688-4699.

90. KUČERKA, N., NIEH, M. AND KATSARAS, J. Fluid phase lipid areas and bilayer thicknesses of commonly used phosphatidylcholines as a function of temperature. Biochimica et Biophysica Acta. 2011, Vol. 1808, pp. 2761-2771.

91. PAN, J., et al. Molecular structures of fluid phase phosphatidylglycerol bilayers as determined by small angle neutron and X-ray scattering. Biochim Biophys Acta. 2012, Vol. 1818,9 , pp. 2135-2148.

92. VERMEER, L. S., et al. Acyl chain order parameter profiles in phospholipid bilayers: computation from molecular dynamics simulations and comparison with $2 \mathrm{H}$ NMR experiments. European Biophysics Journal. 2007, Vol. 36, pp. 919-931.

93. JANOSI, L. AND GORFE, A. A. Simulating POPC and POPC/POPG Bilayers: Conserved Packing and Altered Surface Reactivity. Journal of Chemical Theory and Computation. 2010, Vol. 6, pp. 3267-3273.

94. KOPF-MAIER, P. Complexes of metals other than platinum as antitumour agents. European Journal of Clinical Pharmacology. 1994, Vol. 47, pp. 1-16.

95. THORBURN, A. L. Paul Ehrlich: pioneer of chemotherapy and cure by arsenic (1854-1915). The British journal of venereal diseases. 1983, Vol. 59, pp. 404-405.

96. Van Rijt, S. H. And Sadler, P. J. Current applications and future potential for bioinorganic chemistry in the development of anticancer drugs. Drug Discovery Today. 2009, Vol. 14, 24, pp. 1089-1097.

97. WILSON, C. J., APIYO, D. AND WITTUNG-STAFSHEDE, P. Role of cofactors in metalloprotein folding. Quarterly Reviews of Biophysics. 2004, Vol. 37, pp. 285-314.

98. LIPPARD, S. J. Metals in Medicine. [book auth.] I. Bertini, et al. Bioinoranic Chemistry. Mill Valley : University Science Books, 1994, p. 505. 
99. OLIVEIRA, J. S., et al. An inorganic iron complex that inhibits wild-type and an isoniazid-resistant mutant 2-trans-enoyl-ACP (CoA) reductase from Mycobacterium tuberculosis. Chemical Communications. 2004, Vol. 3, pp. 312-313.

100. ROBERTO, A. S. D. AND ANZELlOtTI, A. Metal Complexes as Chemotherapeutic Agents Against Tropical Diseases: Trypanosomiasis, Malaria and Leishmaniasis. Medical Chemistry. 2004, Vol. 4, 1, pp. 23-30.

101. SARKAR, B. Treatment of Wilson and Menkes Diseases. Chemical Reviews. 1999, Vol. 99, 9, pp. 2535-2544.

102. RIYASDEEN, A., et al. Perspectives in Cancer Prevention-Translational Cancer Research. [ed.] P. R. Sudhakaran. New Delhi : Springer India, 2014, pp. 133-143.

103. SANTINI, C., et al. Advances in Copper Complexes as Anticancer Agents. Chemical Reviews. 2014, Vol. 114, 1, pp. 815-862.

104. CASITAS, A. AND RIBAS, X. The role of organometallic copper(iii) complexes in homogeneous catalysis. Chemical Science. 2013, Vol. 4, 6, pp. 2301-2318.

105. MCDONALD, M. R., FREDERICKS, F. C. AND MARGERUM, D. W. Characterization of Copper(III)-Tetrapeptide Complexes with Histidine as the Third Residue. Inorganic Chemistry. 1997, Vol. 36, 14, pp. 3119-3124.

106. ARJOMAND, M. AND MACHIN, D. J. Oxide chemistry. Part II. Ternary oxides containing copper in oxidation states I, II, III, and IV. Journal of the Chemical Society. 1975, Vol. 11, pp. 1061-1066.

107. SOLOMON, E. I., et al. Copper Active Sites in Biology. Chemical Reviews. 2014, Vol. 114, 7, pp. 3659-3853.

108. ZUO, X. L., et al. Levels of selenium, zinc, copper, and antioxidant enzyme activity in patients with leukemia. Biological Trace Element Research. 2006, Vol. 114, 1, p. 41. 
109. ADENIYI, A. A. AND AJIBADE, P. A. The Anticancer Activities of Some Nitrogen Donor Ligands Containing bis-Pyrazole, Bipyridine, and Phenanthroline Moiety Using Docking Methods. Bioinorganic Chemistry and Applications. 2018, Vol. 2018.

110. GANDRA, R. M., ET al. Antifungal Potential of Copper(II), Manganese(II) and Silver(I) 1,10-Phenanthroline Chelates Against Multidrug-Resistant Fungal Species Forming the Candida haemulonii Complex: Impact on the Planktonic and Biofilm Lifestyles. Frontier in Microbiology. 2017, Vol. 8, 1257.

111. MARZANO, C., et al. Copper Complexes as Anticancer Agents. Anti-Cancer Agents in Medicinal Chemistry. 2009, Vol. 9, pp. 185-211.

112. TISATO, F., et al. Copper in diseases and treatments, and copper-based anticancer strategies. Medicinal Research Reviews. 2010, Vol. 30, 4, pp. 708-749.

113. SERMENT-GUERRERO, J., et al. Genotoxicity of the copper antineoplastic coordination complexes casiopeinas ${ }^{\circledR}$. Toxicology in Vitro. 2011, Vol. 25, pp. 1376-1384.

114. FACCHIN, G., et al. Interaction of Cu-dipeptide complexes with Calf Thymus DNA and antiproliferative activity of [Cu(ala-phe)] in osteosarcoma-derived cells. Polyhedron. 2009, Vol. 28, 12, pp. 2329-2334.

115. ALVAREZ, N., et al. Synthesis, structural characterization and DNA interaction of new copper-terpyridine complexes. Polyhedron. 2013.

116. ALVAREZ, N., et al. Synthesis, structural characterization and cytotoxic activity against tumor cells of heteroleptic copper (I) complexes with aromatic diimines and phosphines. Inorganica Chimica Acta. 2017, Vol. 446, pp. 559-564.

117. IGLESIAS, S., et al. Structural Characterization and Cytotoxic Activity of Heteroleptic Copper (II) Complexes with L-Dipeptides and 5-NO2-Phenanthroline. Crystal Structure of $[\mathrm{Cu}(\mathrm{Phe}-\mathrm{Ala})(5-\mathrm{NO} 2-\mathrm{Phen})] .4 \mathrm{H} 2 \mathrm{O}$. Structural Chemistry \& Crystallography Communication. 2015, Vol. 1, 1:7. 
118. LIU, Q., et al. Mechanism of the Membrane Interaction of Polynuclear Platinum Anticancer Agents. Implications for Cellular Uptake. Biochemistry. 2006, Vol. 45, pp. 42484256.

119. GARCIA-RAMOS, J. C., et al. Isomeric Effect on the Pharmacokinetic Behavior of Anticancer Cull Mixed Chelate Complexes: Experimental and Theoretical Chelate Complexes: Experimental and Theoretical. European Journal of Inorganic Chemistry. 2017, Vol. 2017, pp. 1728-1736.

120. SELVARAJ,, S., et al. Investigations on Membrane Perturbation by Chrysin and Its Copper Complex Using Self-Assembled Lipid Bilayers. Langmuir. 2011, Vol. 27, pp. 1337413382.

121. BAL, W., et al. A Dramatic Change in the Interaction of $\mathrm{Cu}(\mathrm{I} 1)$ with 'Bio-Peptides Promoted by SDS - a Model for Complex Formation on a Membrane Surface. Journal of Inorganic Biochemistry. 1994, Vol. 55, pp. 41-52.

122. ALVES, A. C., et al. Biophysics in cancer: The relevance of drug-membrane interaction studies. Biochimica et Biophysica Acta. 2016, Vol. 1858, pp. 2231-2244.

123. ZHAO L., et al. DSC and EPR investigations on effects of cholesterol component on molecular interactions between paclitaxel and phospholipid within lipid bilayer membrane. International Journal of Pharmaceutics. 2007, Vol. 338, pp. 258-266.

124. DEMETZOS, C. Differential Scanning Calorimetry (DSC): A Tool to study the thermal behavior of lipid bilayers and lipossomal stability. Journal of Lipossome Research. 2008, Vol. 18, pp. 159-173.

125. LEWIS, R. A. A. H., Mak, N. and McElhaney, R. N. A Differential Scanning Calorimetry Study of the Thermotropic Phase behavior of Model Membranes composed of Phosphatidylcholines containing Linear Satured Acyl Chains. Biochemistry. 1987, Vol. 26, pp. 6118-6126. 
126. Jain, M. K. And Wu, N. M. Effect of Small Molecules on the Dipalmitoyl Lecithin Liposomal Bilayer: III. Phase Transition in Lipid Bilayer. Journal of Membrane Biology. 1977, Vol. 34, pp. 157-201.

127. JOBIN, M. L. , et al. The enhanced membrane interaction and perturbation of a cell penetrating peptide in the presence of anionic lipids: Toward an understanding of its selectivity for cancer cells. Biochimica et Biophysica Acta. 2013, Vol. 1828, pp. 1457-1470.

128. BASSO, L. G. M., et al. SARS-CoV fusion peptides induce membrane surface ordering and curvature. Scientific Reports. 2016, Vol. 6, p. 37131.

129. EPAND, R. M. Fusion peptides and the mechanism of viral fusion. 2003, Biochimica et Biophysica Acta, Vol. 1614, pp. 116- 121.

130. SCHIBLI, D. J. AND WEISSENHORN, W. Class I and class II viral fusion protein structures reveal similar principles in membrane fusion (Review). 2004, Molecular Membrane Biology, Vol. 21, pp. 361-371. 


\section{APÊNDICE A}

Nesta seção, apresentamos material complementar ao texto principal da tese que possa servir como suporte para o entendimento e/ou análises dos dados dos experiementos de RPE com os complexos metálicos, discutidos na seção 4.2.2, desta tese.

\section{A1. Modelo de membrana: DPPC}

Nesta seção apresentamos os espectros de RPE com o mimético de membrana DPPC e as sondas 5 e 16-PCSL e DOPTC, na ausência e na presenca dos compostos de interesse (Figuras 47-61).

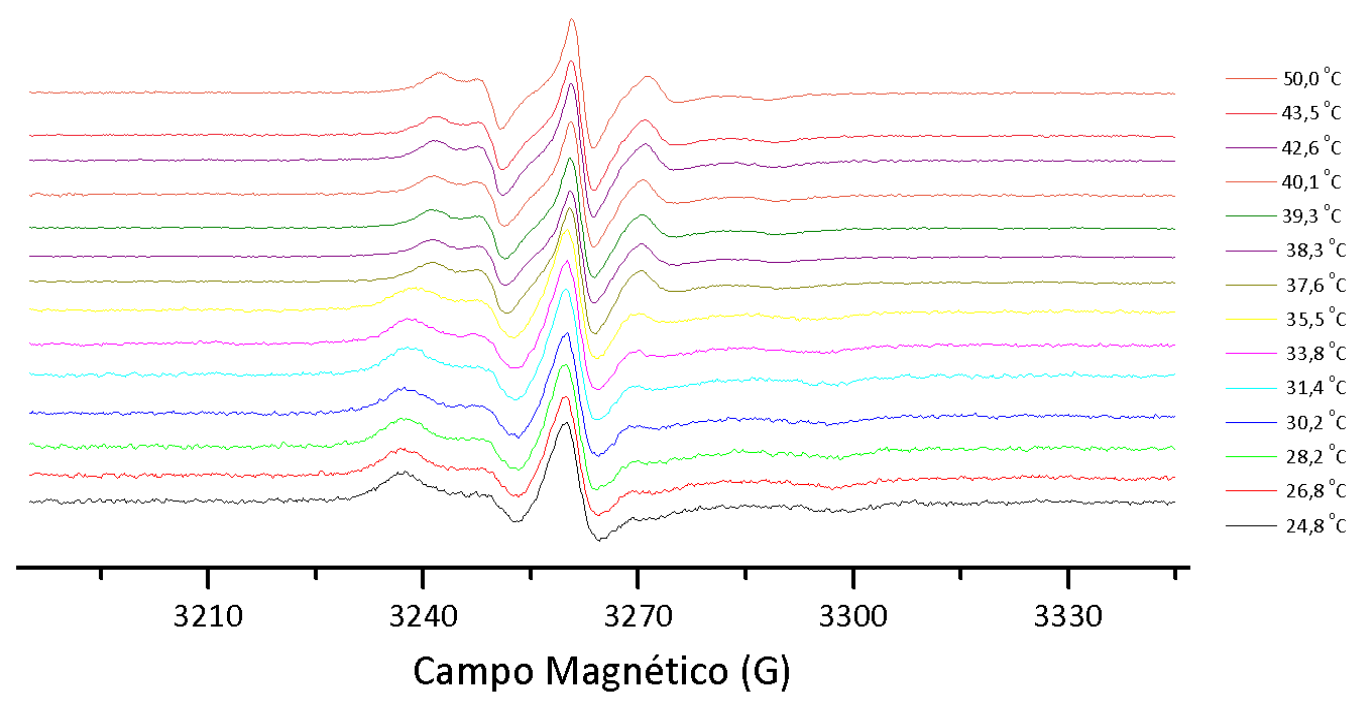

Figura 47 - Espectros de RPE em função da temperatura das modelos de membrana contendo DPPC e a sonda 5-PCSL. Figura elaborada pela autora. 


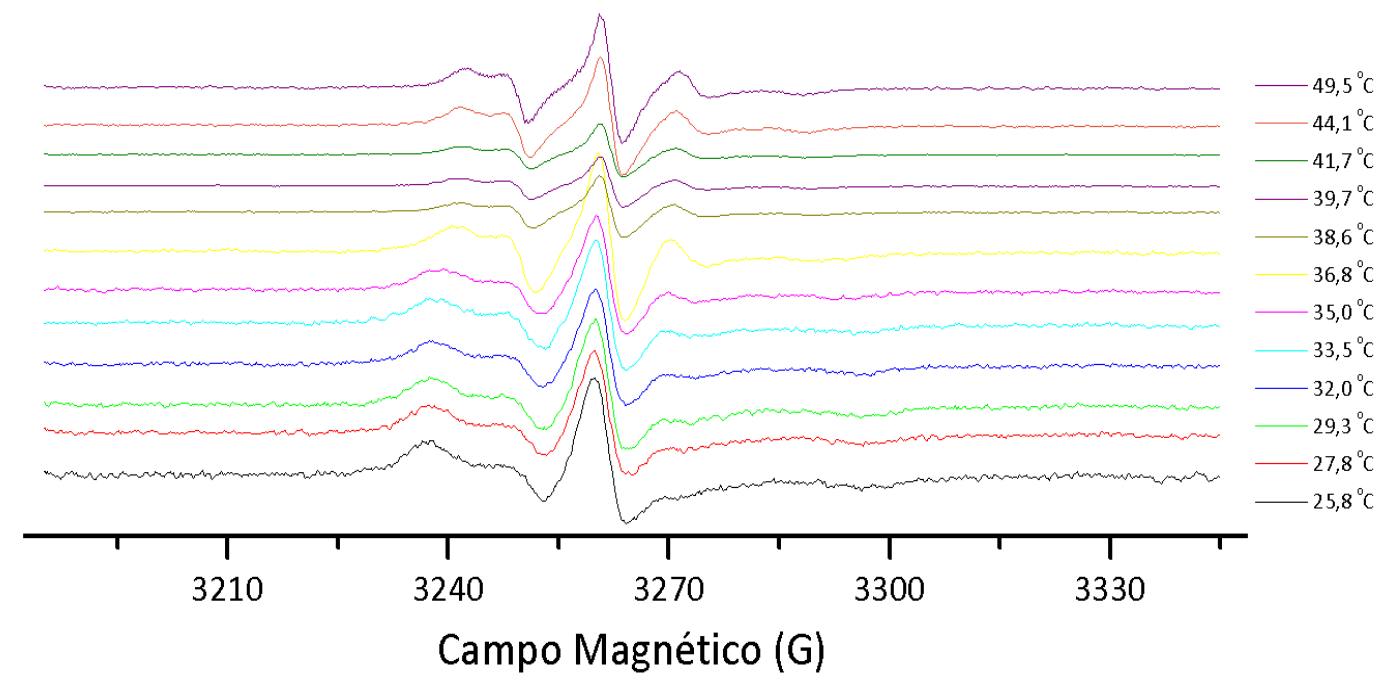

Figura 48 - Espectros de RPE em função da temperatura das modelos de membrana contendo DPPC e a sonda 5-PCSL na presença do ligante phen. Figura elaborada pela autora.

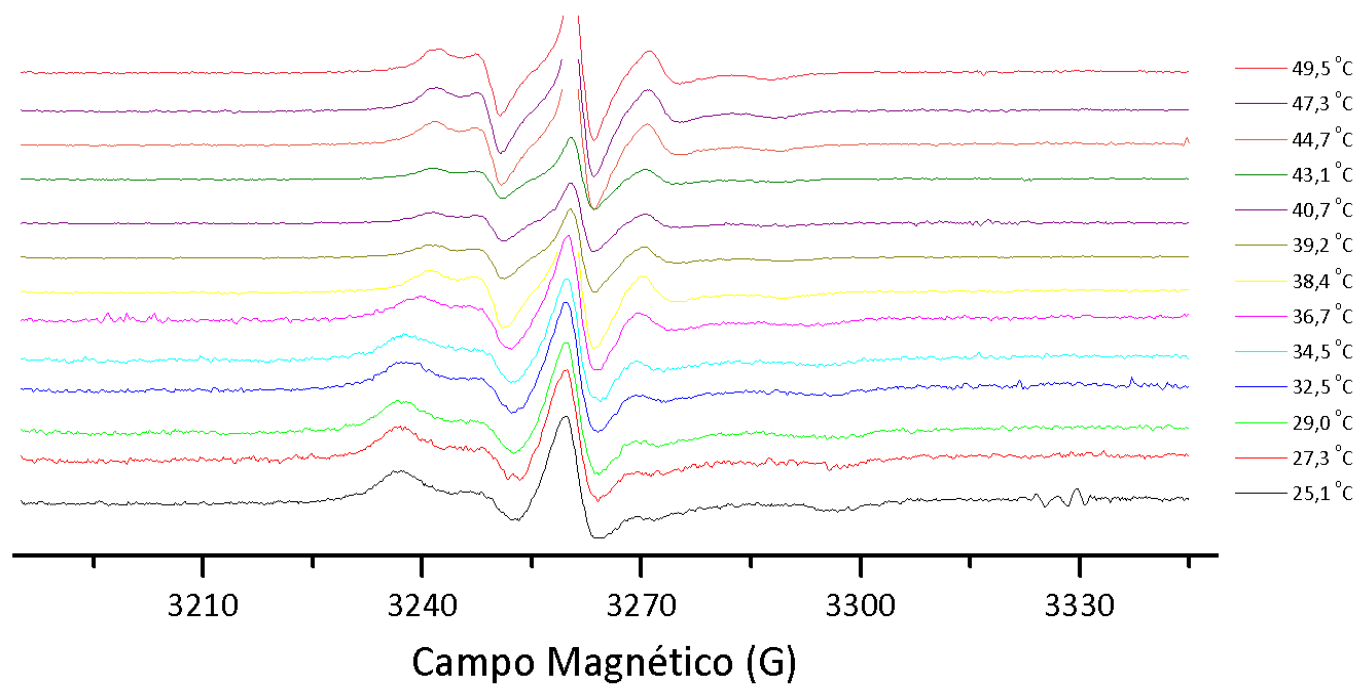

Figura 49 - Espectros de RPE em função da temperatura das modelos de membrana contendo DPPC e a sonda 5-PCSL na presença do complexo Cu(phen). Figura elaborada pela autora. 


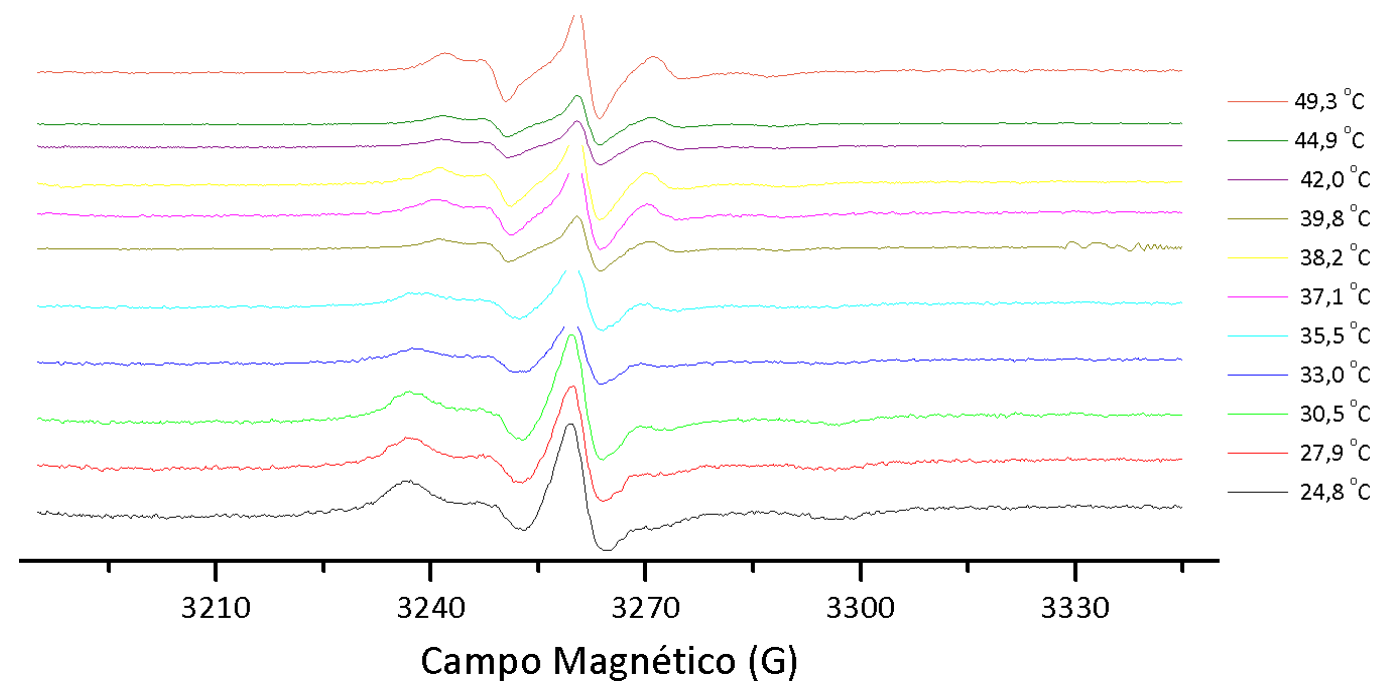

Figura 50 - Espectros de RPE em função da temperatura das modelos de membrana contendo DPPC e a sonda 5-PCSL na presença do complexo $\mathrm{Cu}(\mathrm{AG})(\mathrm{phen})$. Figura elaborada pela autora.

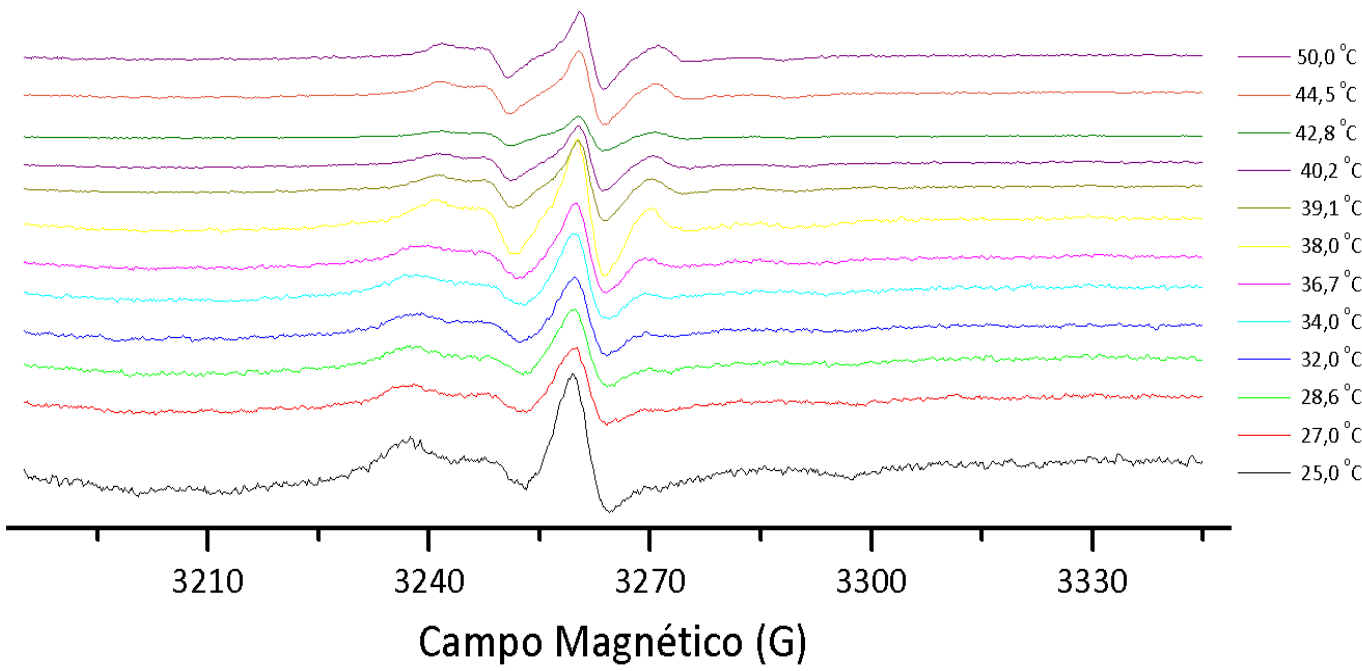

Figura 51 - Espectros de RPE em função da temperatura das modelos de membrana contendo DPPC e a sonda 5-PCSL na presença do complexo Cu(AP)(phen). Figura elaborada pela autora. 


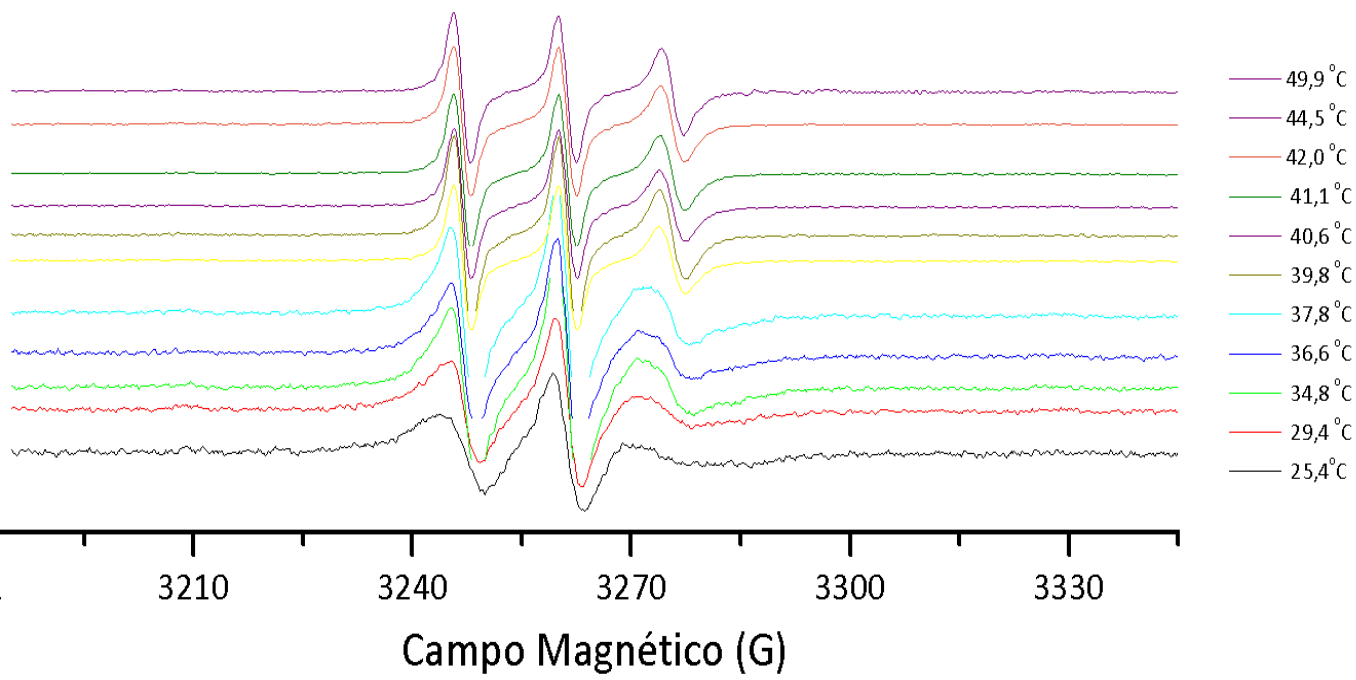

Figura 52 - Espectros de RPE em função da temperatura das modelos de membrana contendo DPPC e a sonda 16-PCSL. Figura elaborada pela autora.

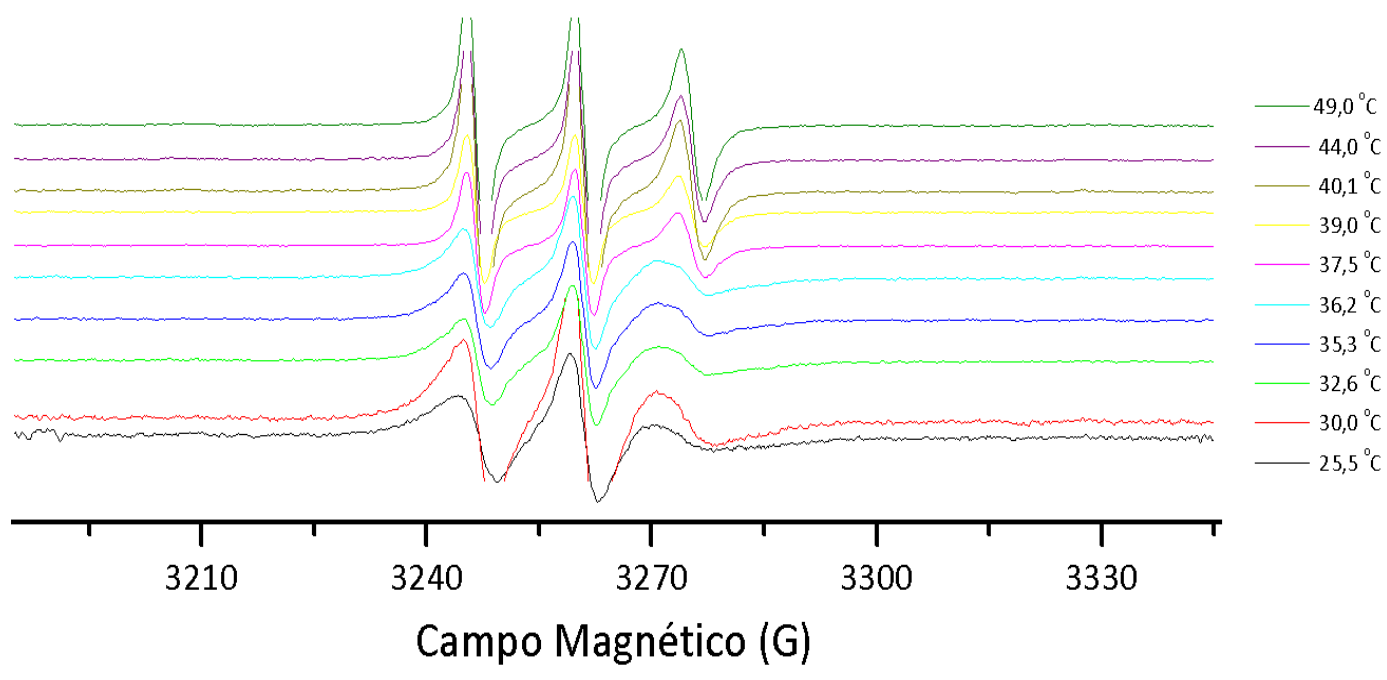

Figura 53 - Espectros de RPE em função da temperatura das modelos de membrana contendo DPPC e a sonda 16-PCSL na presença da molécula phen. Figura elaborada pela autora. 


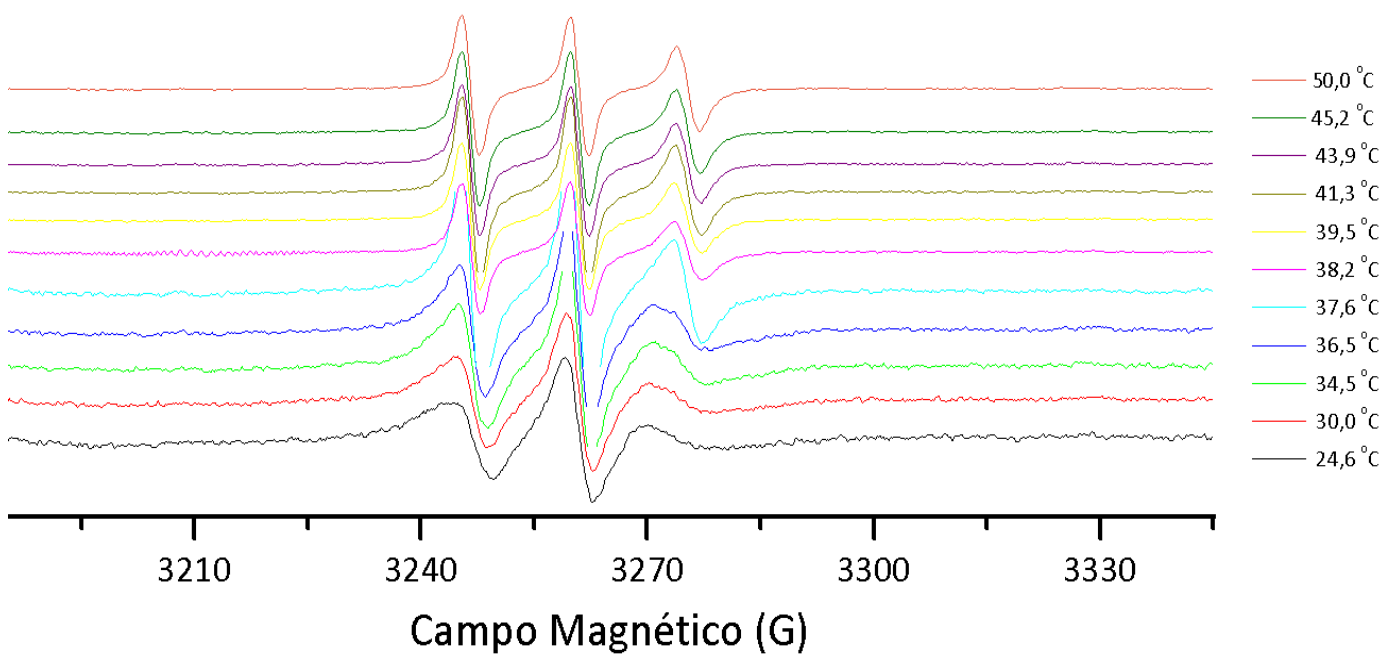

Figura 54 - Espectros de RPE em função da temperatura das modelos de membrana contendo DPPC e a sonda 16-PCSL na presença do complexo $\mathrm{Cu}($ phen). Figura elaborada pela autora.

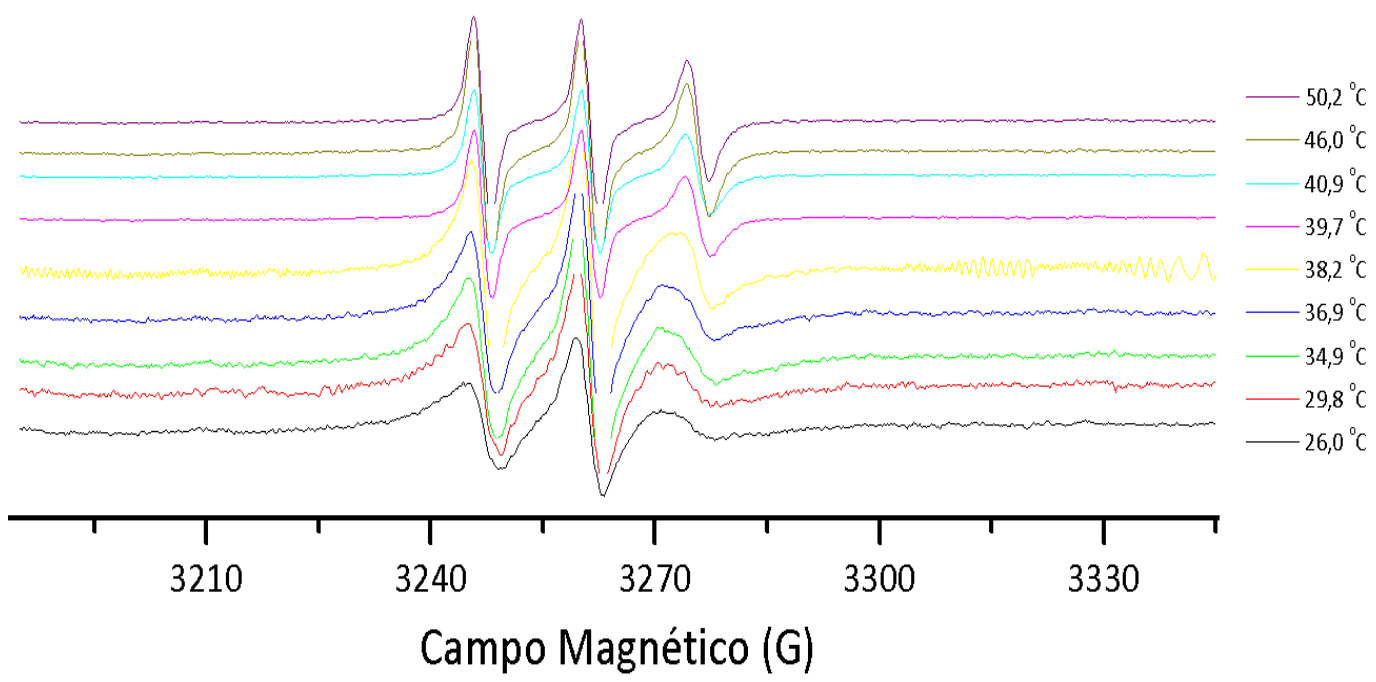

Figura 55 - Espectros de RPE em função da temperatura das modelos de membrana contendo DPPC e a sonda 16-PCSL na presença do complexo $\mathrm{Cu}(\mathrm{AG})(\mathrm{phen})$. Figura elaborada pela autora. 


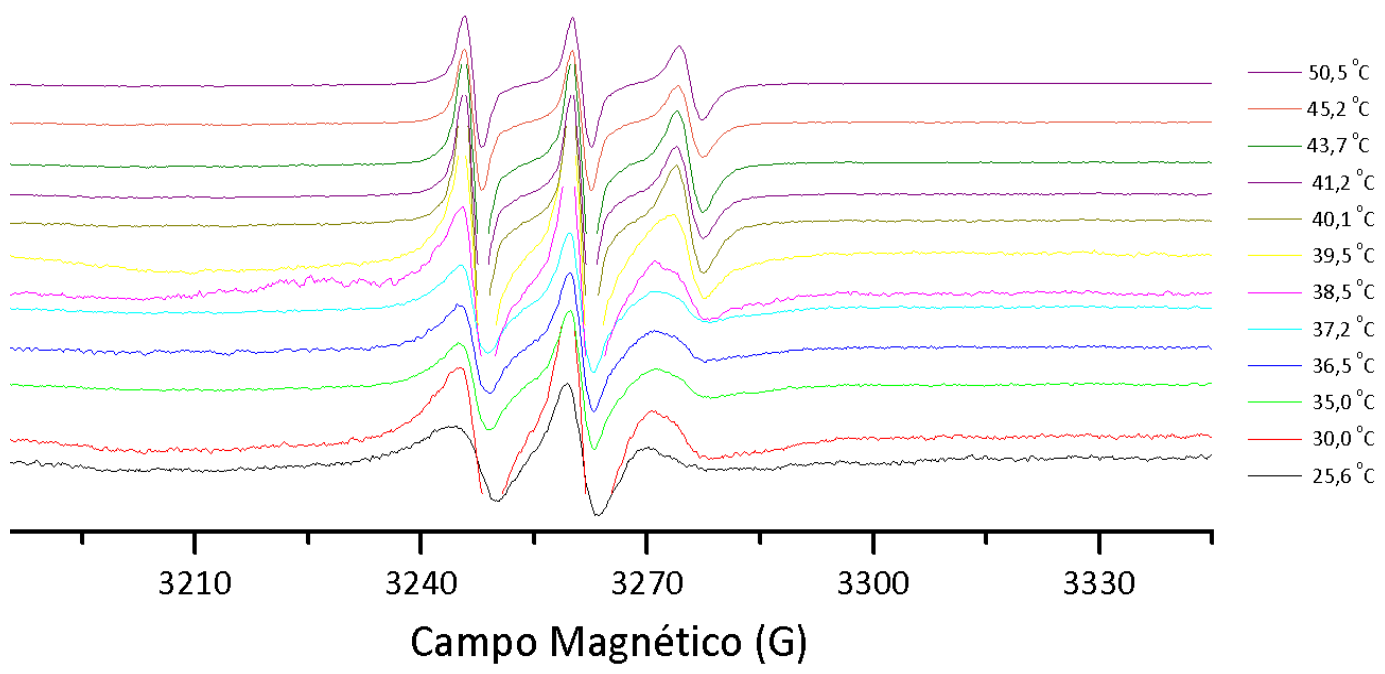

Figura 56 - Espectros de RPE em função da temperatura das modelos de membrana contendo DPPC e a sonda 16-PCSL na presença do complexo Cu(AP)(phen). Figura elaborada pela autora.

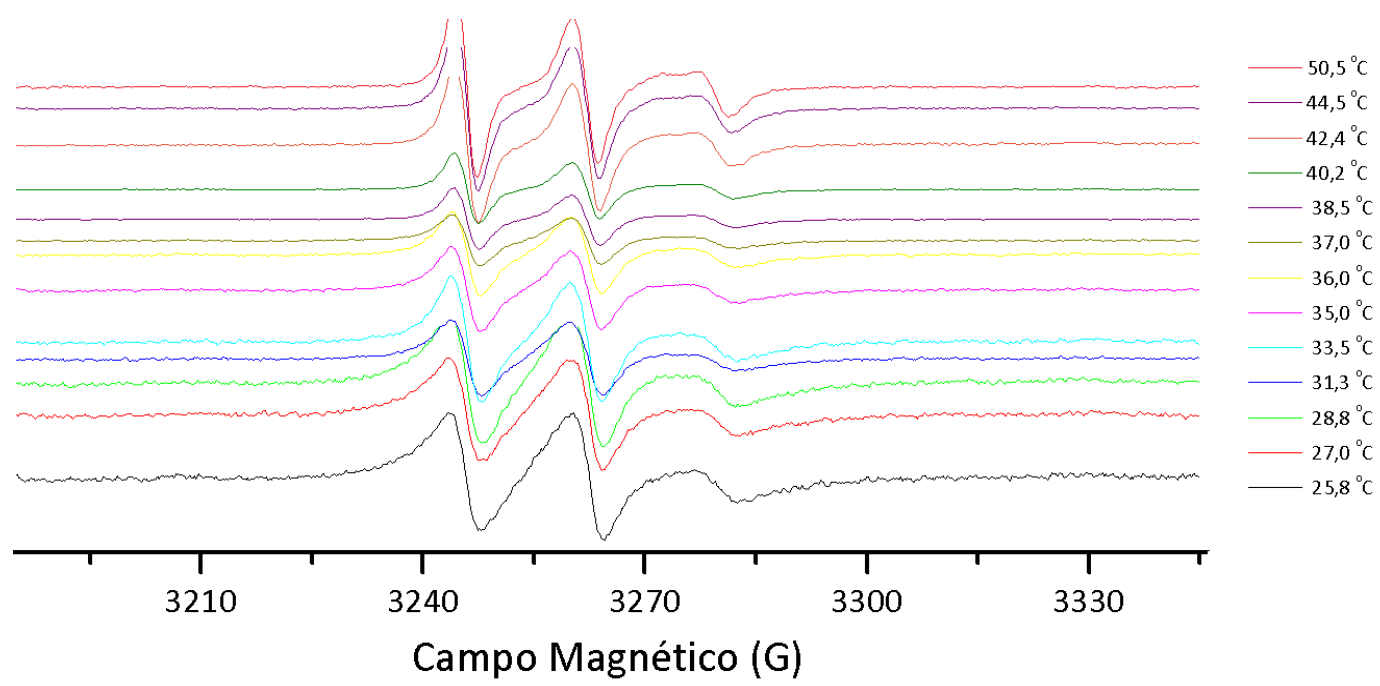

Figura 57 - Espectros de RPE em função da temperatura das modelos de membrana contendo DPPC e a sonda DOPTC. Figura elaborada pela autora. 


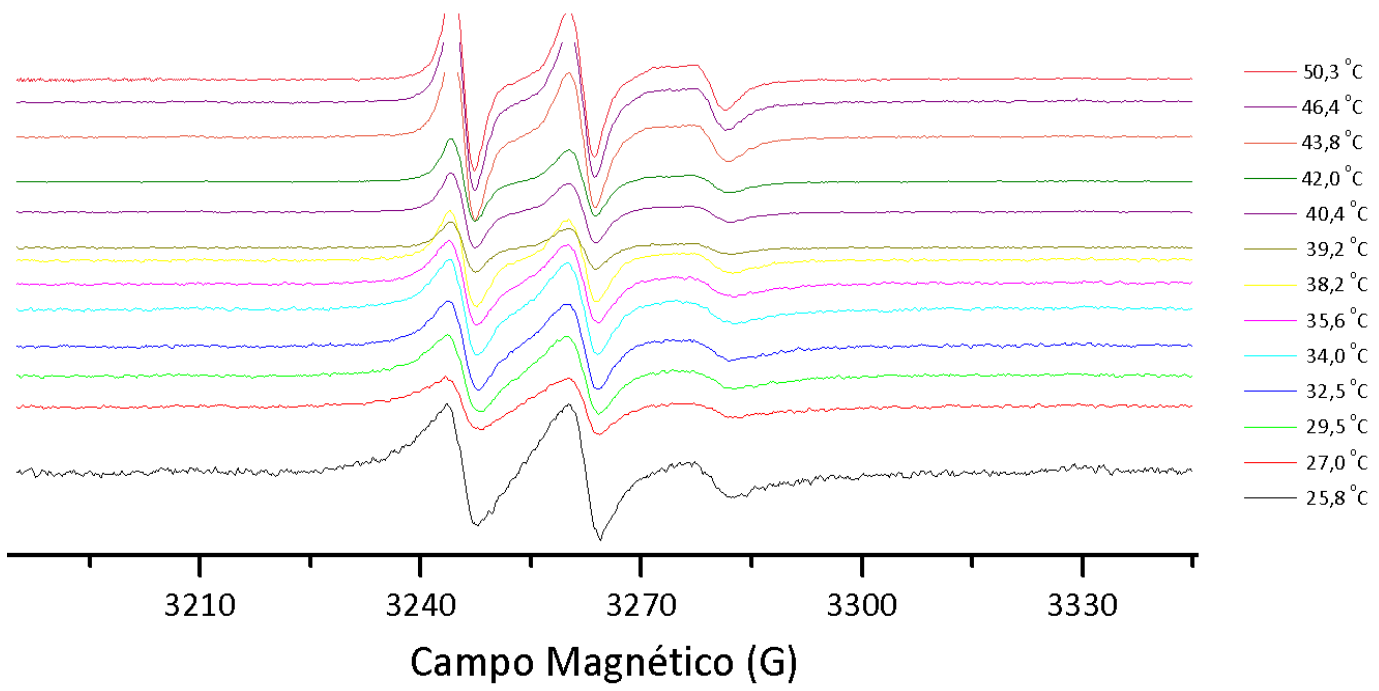

Figura 58 - Espectros de RPE em função da temperatura das modelos de membrana contendo DPPC e a sonda DOPTC, na presença da molécula de phen. Figura elaborada pela autora.

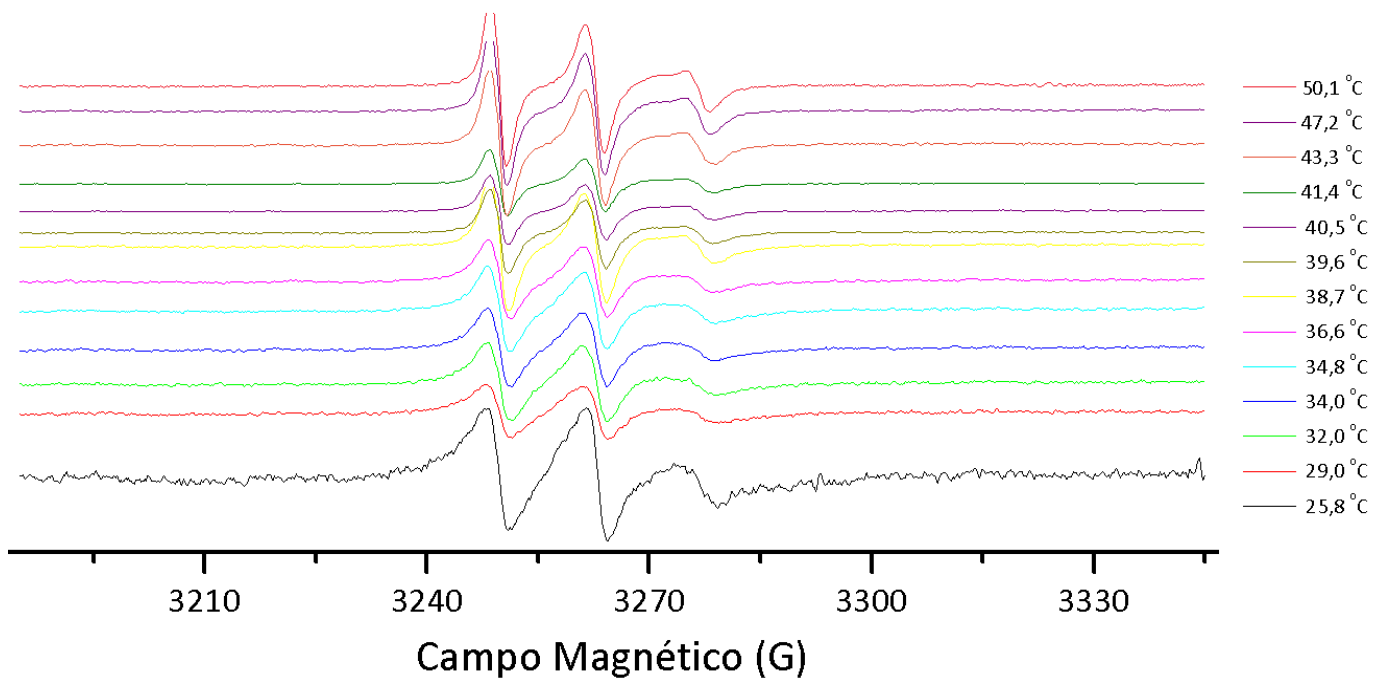

Figura 59 - Espectros de RPE em função da temperatura das modelos de membrana contendo DPPC e a sonda DOPTC, na presença do complexo Cu(phen). Figura elaborada pela autora. 


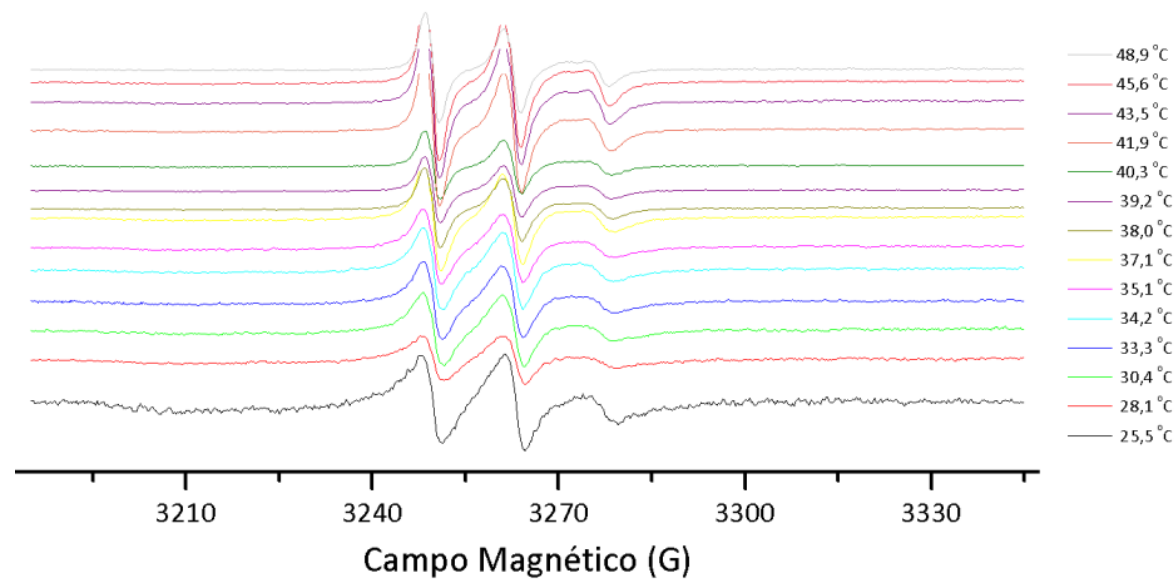

Figura 60 - Espectros de RPE em função da temperatura das modelos de membrana contendo DPPC e a sonda DOPTC, na presença do complexo $\mathrm{Cu}(\mathrm{AG})(\mathrm{phen})$. Figura elaborada pela autora.

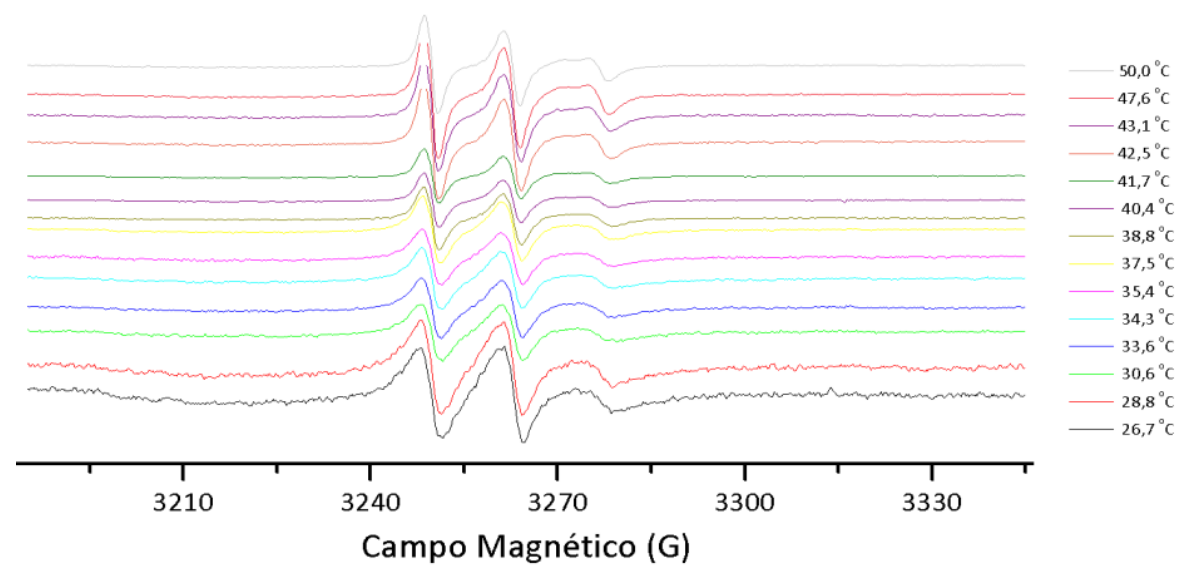

Figura 61 - Espectros de RPE em função da temperatura das modelos de membrana contendo DPPC e a sonda DOPTC, na presença do complexo $\mathrm{Cu}(\mathrm{AP})($ phen). Figura elaborada pela autora.

\section{A2. Modelo de membrana: DPPG}

Nesta seção apresentamos os espectros de RPE com o mimético de membrana DPPG e as sondas 5 e 16-PCSL e DOPTC, na ausência e na presenca dos compostos de interesse (Figuras 62-76). 


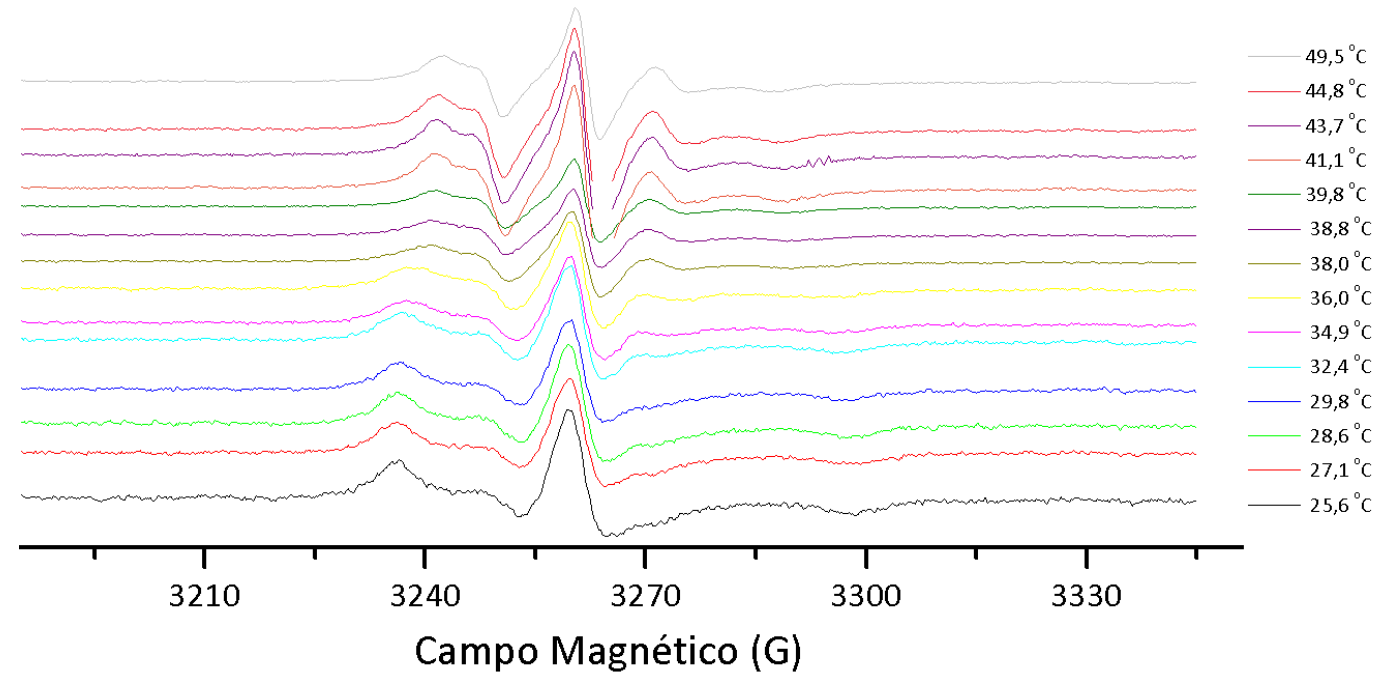

Figura 62 - Espectros de RPE em função da temperatura das modelos de membrana contendo DPPG e a sonda 5-PCSL. Figura elaborada pela autora.

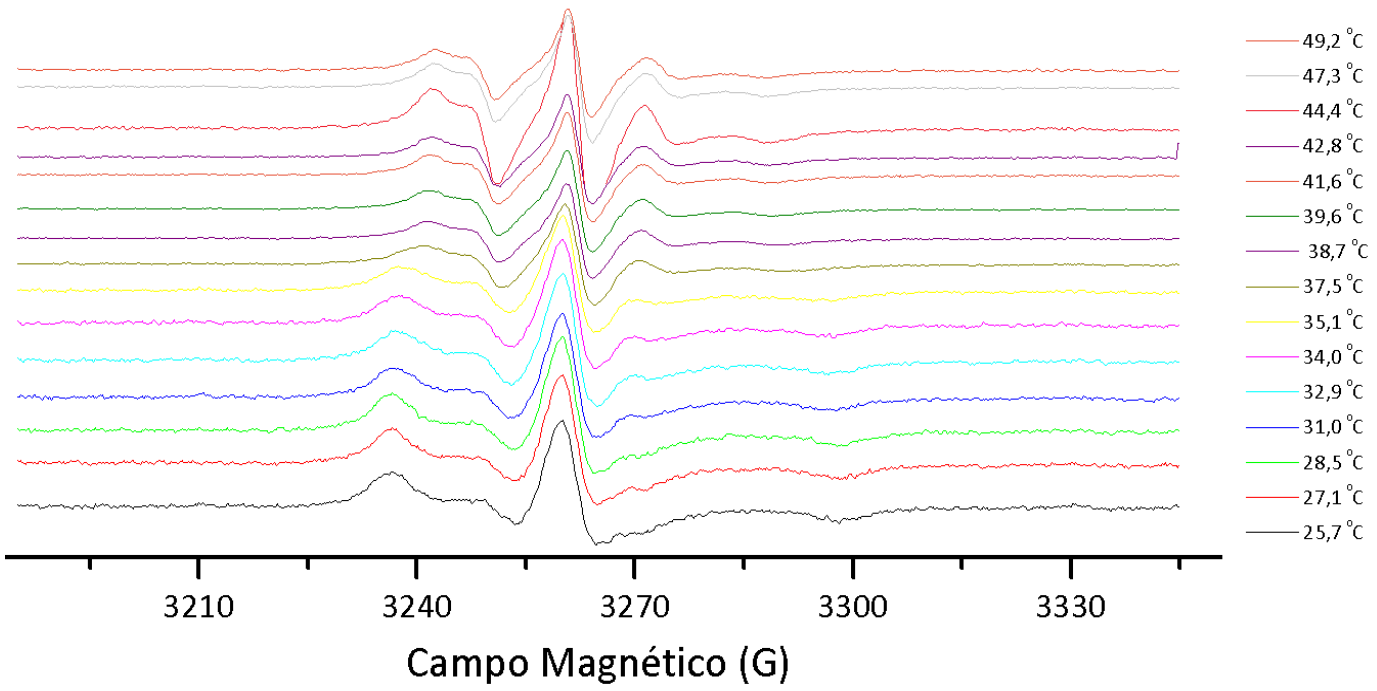

Figura 63 - Espectros de RPE em função da temperatura das modelos de membrana contendo DPPG e a sonda 5-PCSL na presença da molécula phen. Figura elaborada pela autora. 


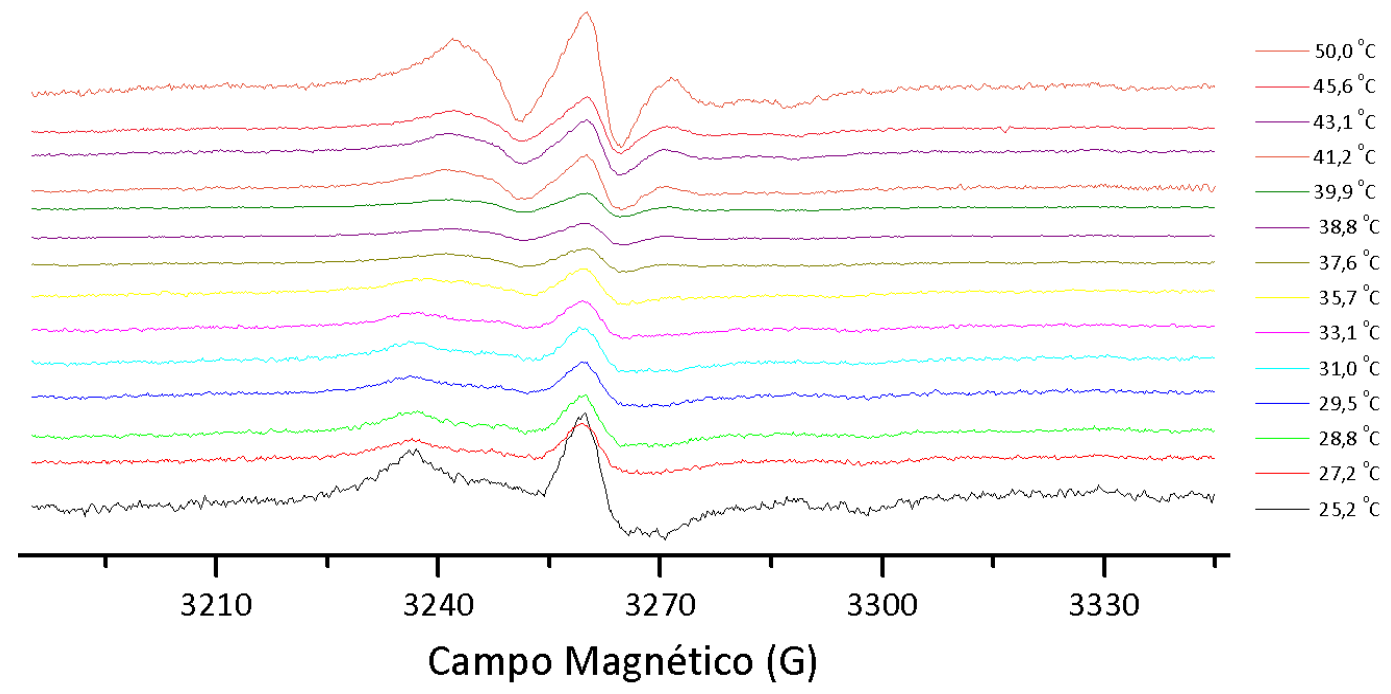

Figura 64 - Espectros de RPE em função da temperatura das modelos de membrana contendo DPPG e a sonda 5-PCSL na presença do complexo Cu(phen). Figura elaborada pela autora.

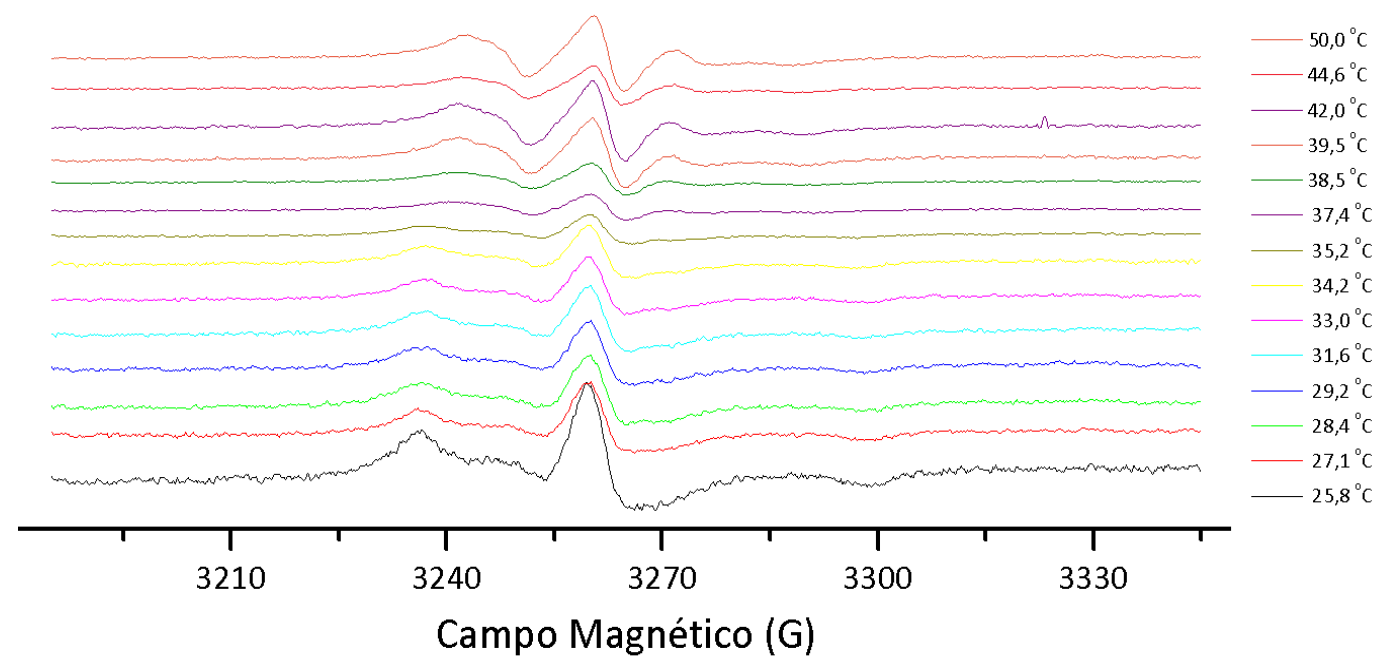

Figura 65 - Espectros de RPE em função da temperatura das modelos de membrana contendo DPPG e a sonda 5-PCSL na presença do complexo $\mathrm{Cu}(\mathrm{AG})(\mathrm{phen})$. Figura elaborada pela autora. 


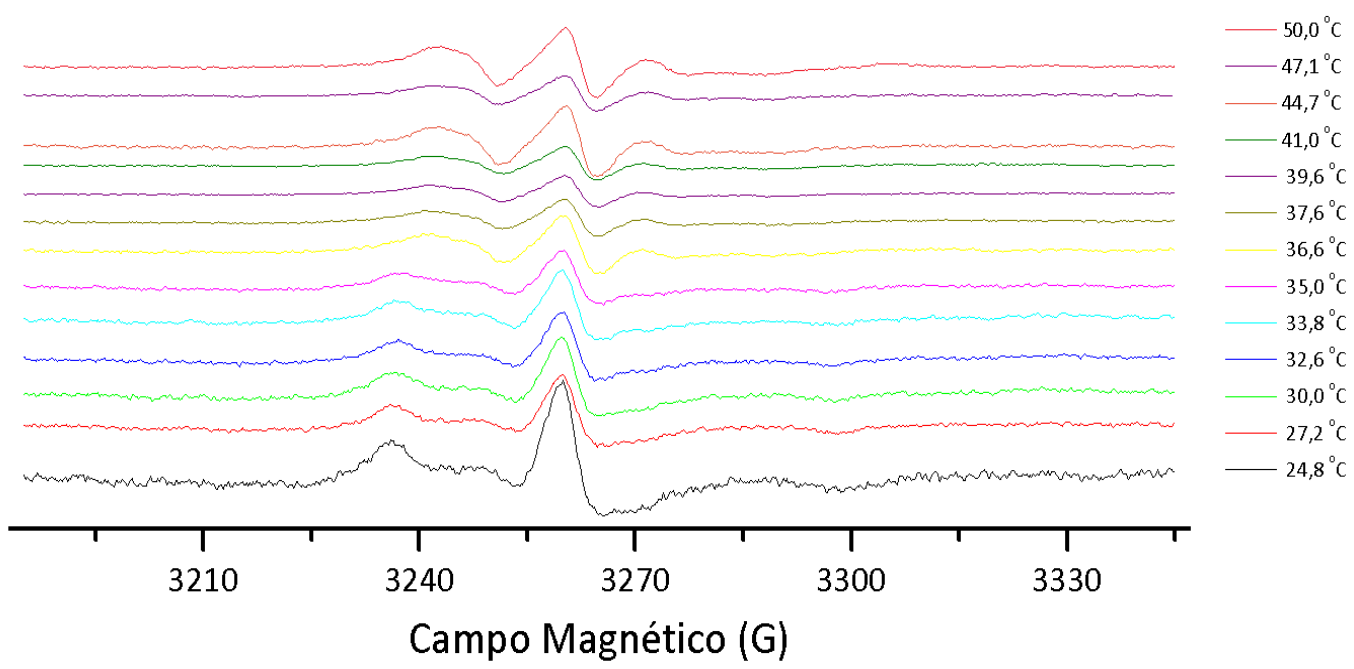

Figura 66 - Espectros de RPE em função da temperatura das modelos de membrana contendo DPPG e a sonda 5-PCSL na presença do complexo $\mathrm{Cu}(\mathrm{AP})(\mathrm{phen})$. Figura elaborada pela autora.

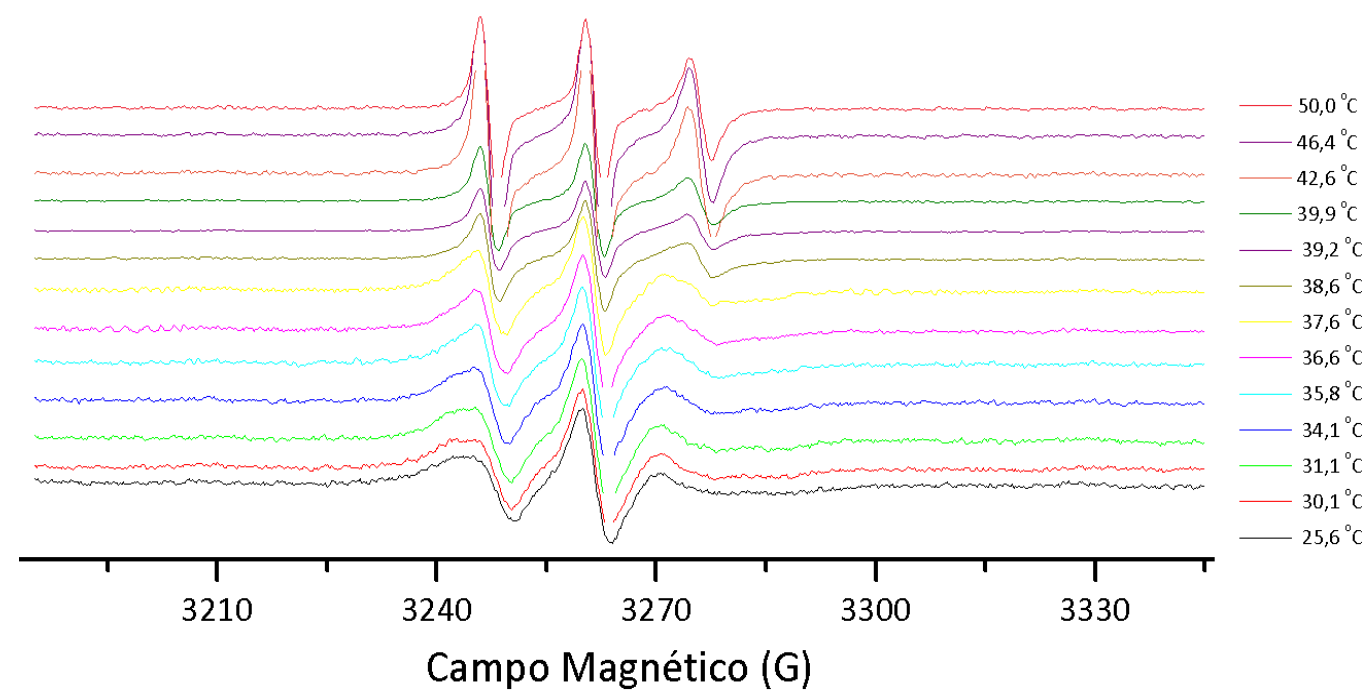

Figura 67 - Espectros de RPE em função da temperatura das modelos de membrana contendo DPPG e a sonda 16-PCSL. Figura elaborada pela autora. 


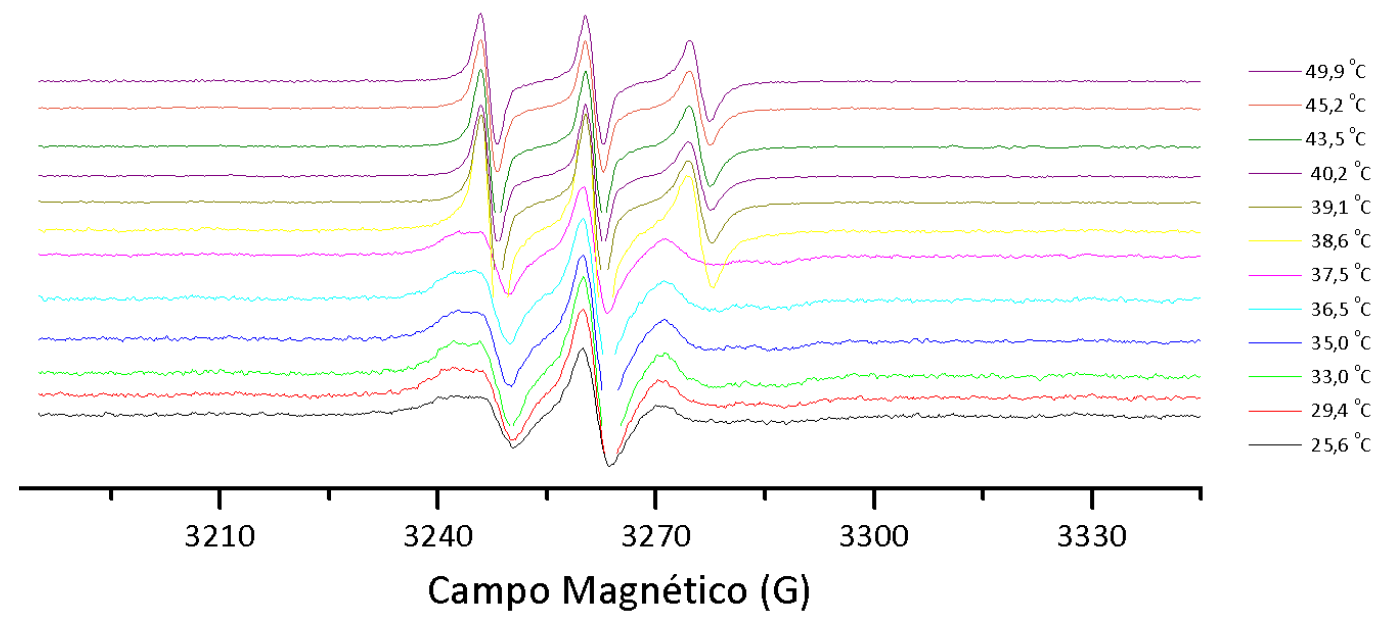

Figura 68 - Espectros de RPE em função da temperatura das modelos de membrana contendo DPPG e a sonda 16-PCSL na presença do ligante phen. Figura elaborada pela autora.

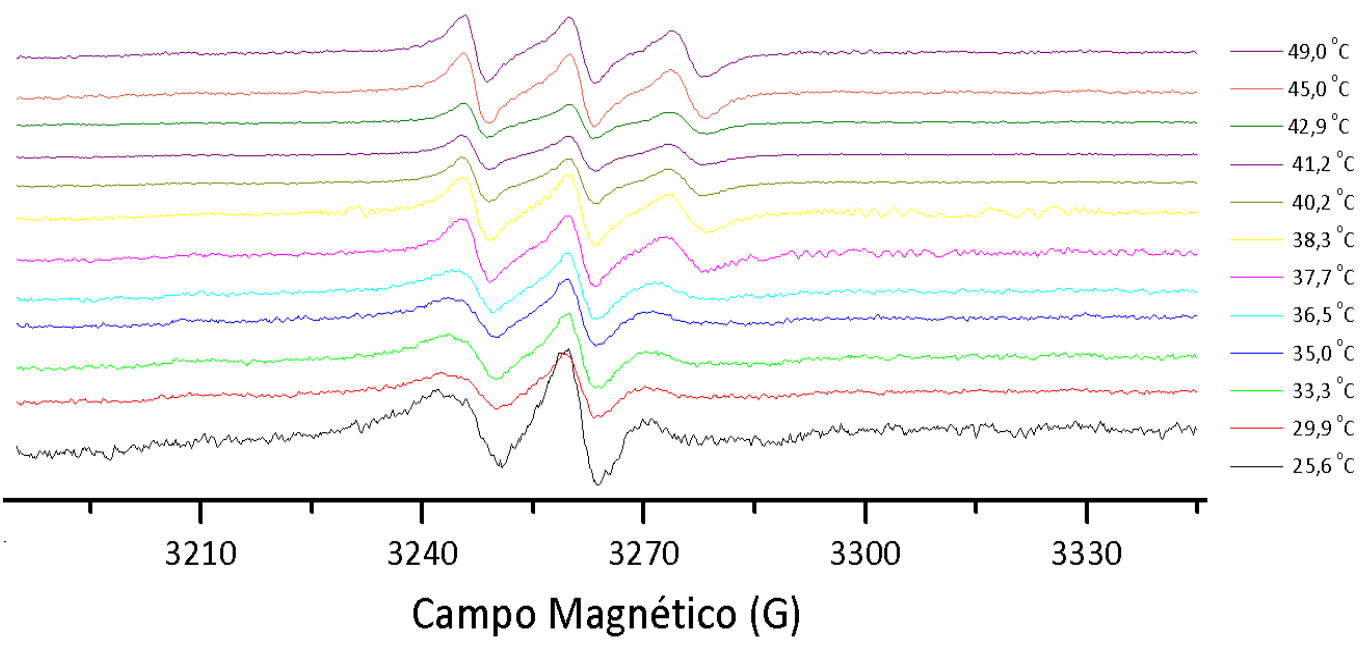

Figura 69 - Espectros de RPE em função da temperatura das modelos de membrana contendo DPPG e a sonda 16-PCSL na presença do complexo $\mathrm{Cu}(p h e n)$. Figura elaborada pela autora. 


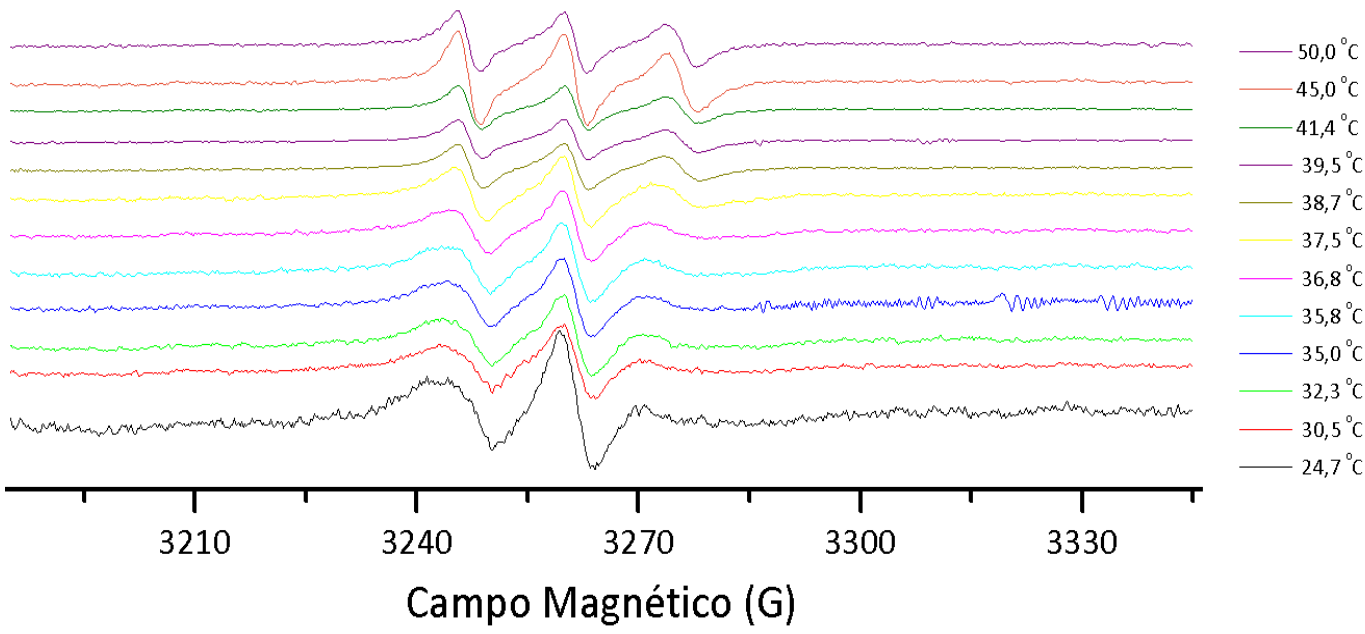

Figura 70 - Espectros de RPE em função da temperatura das modelos de membrana contendo DPPG e a sonda 16-PCSL na presença do complexo $\mathrm{Cu}(\mathrm{AG})($ phen). Figura elaborada pela autora.

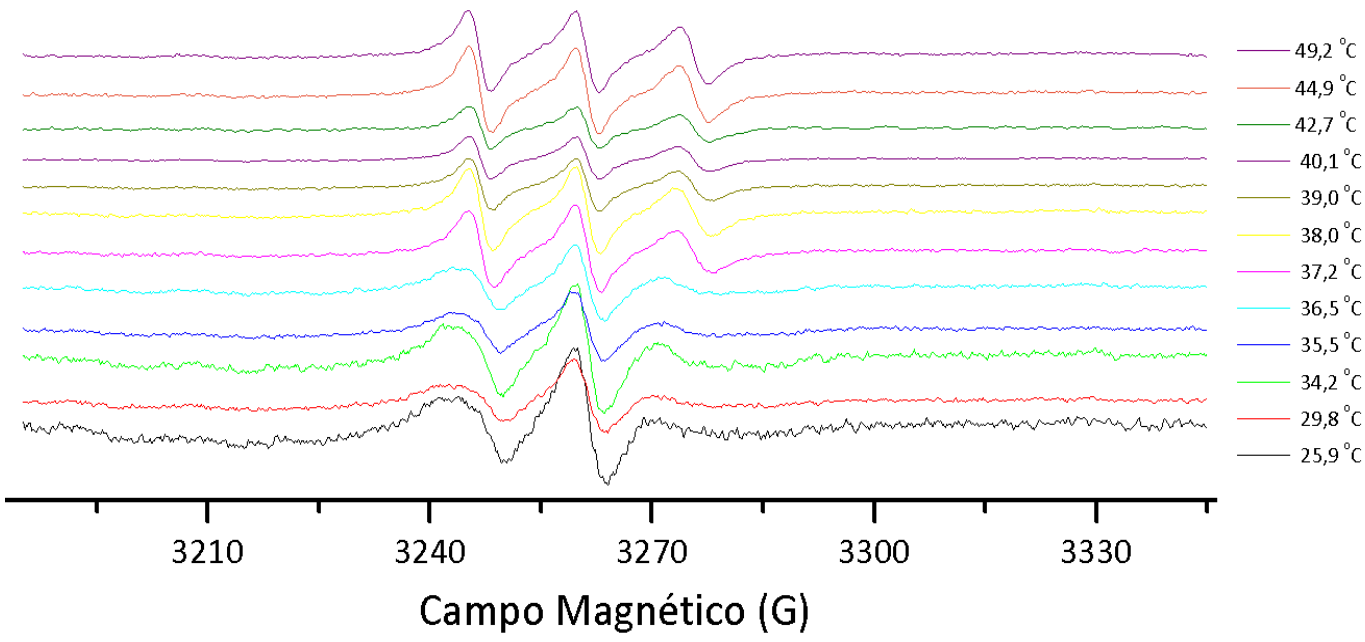

Figura 71 - Espectros de RPE em função da temperatura das modelos de membrana contendo DPPG e a sonda 16-PCSL na presença do complexo $\mathrm{Cu}(\mathrm{AP})(\mathrm{phen})$. Figura elaborada pela autora. 


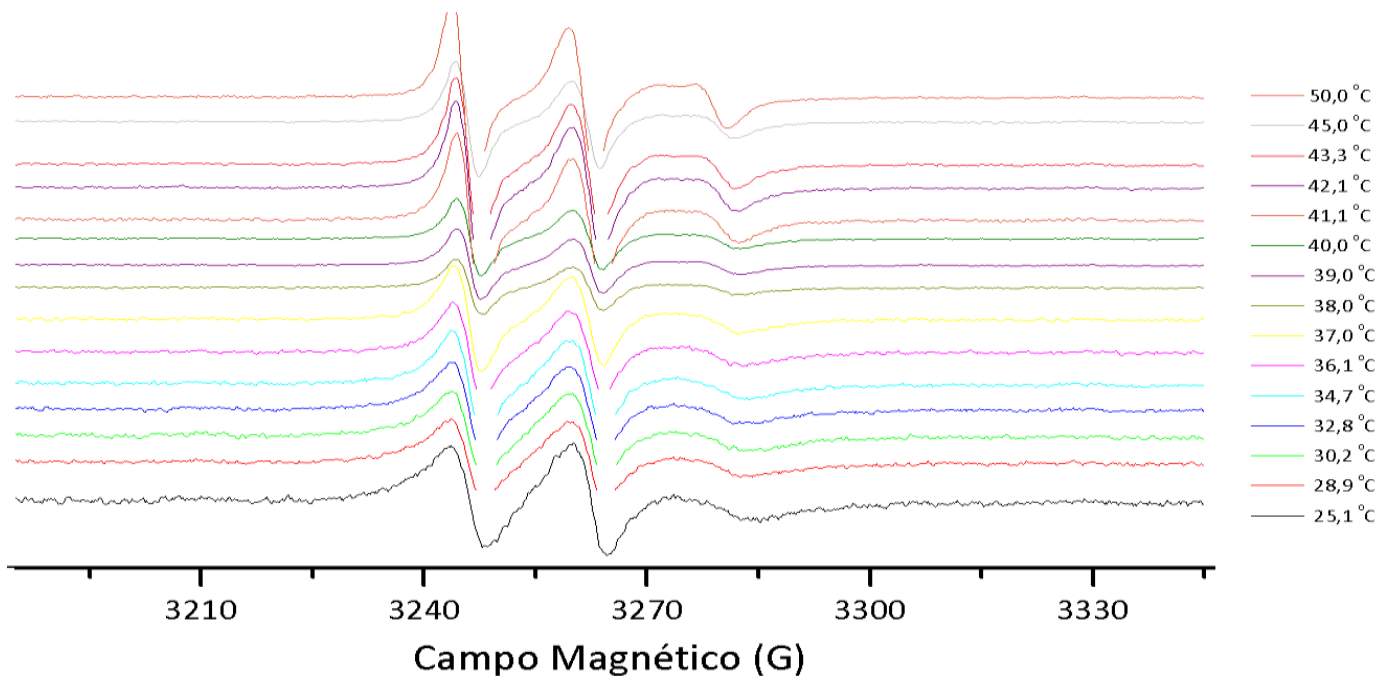

Figura 72 - Espectros de RPE em função da temperatura das modelos de membrana contendo DPPG e a sonda DOPTC. Figura elaborada pela autora.

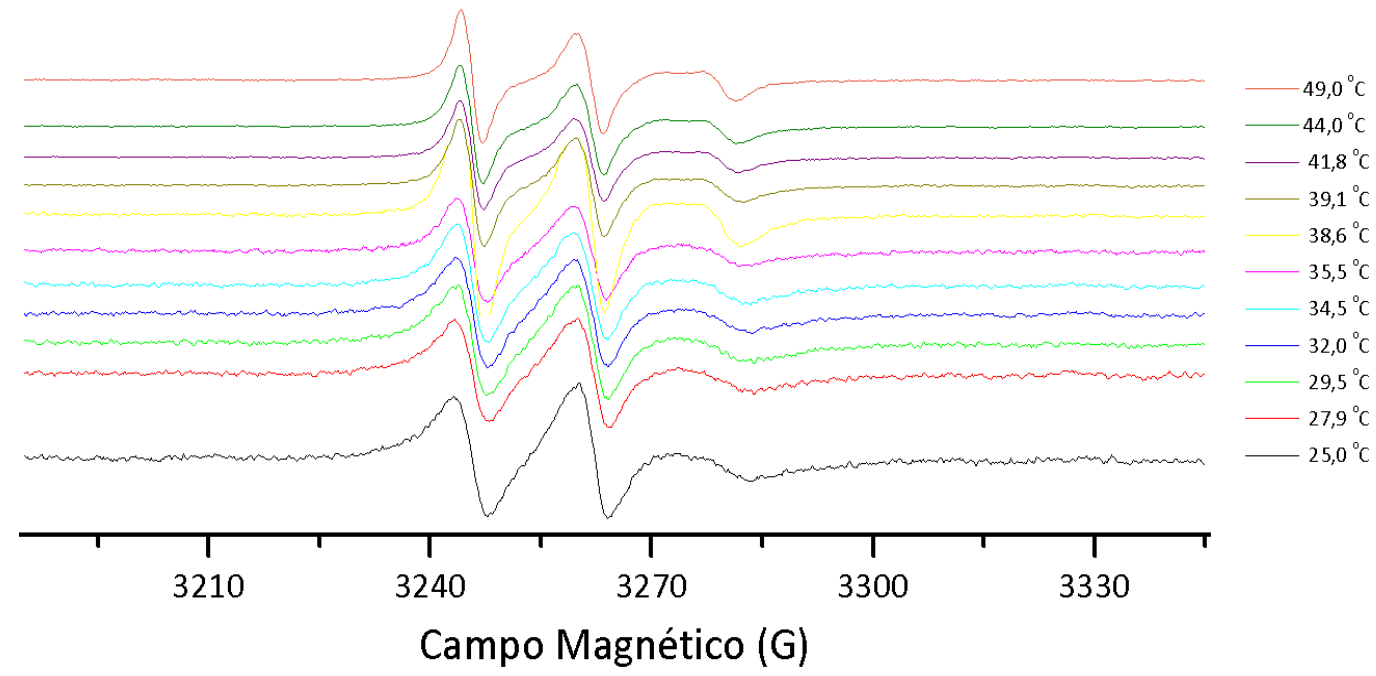

Figura 73 - Espectros de RPE em função da temperatura das modelos de membrana contendo DPPG e a sonda DOPTC na presença da molécula phen. Figura elaborada pela autora. 


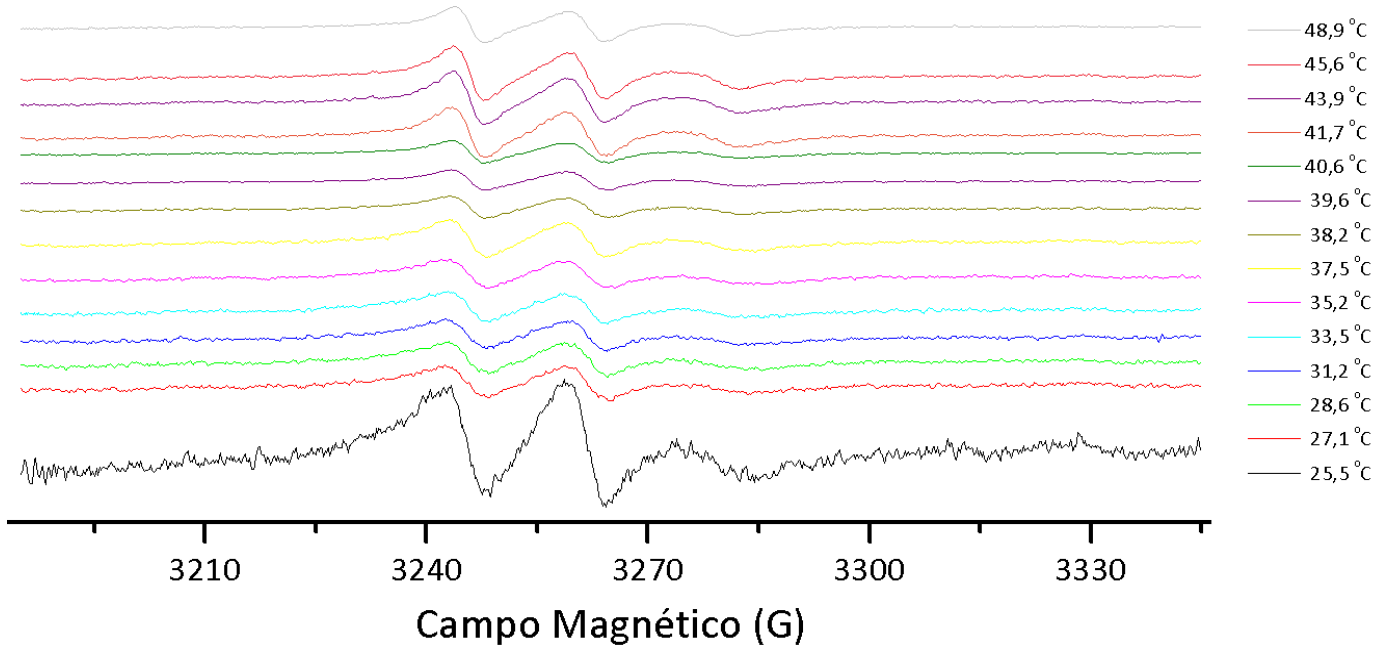

Figura 74 - Espectros de RPE em função da temperatura das modelos de membrana contendo DPPG e a sonda DOPTC na presença do complexo Cu(phen). Figura elaborada pela autora.

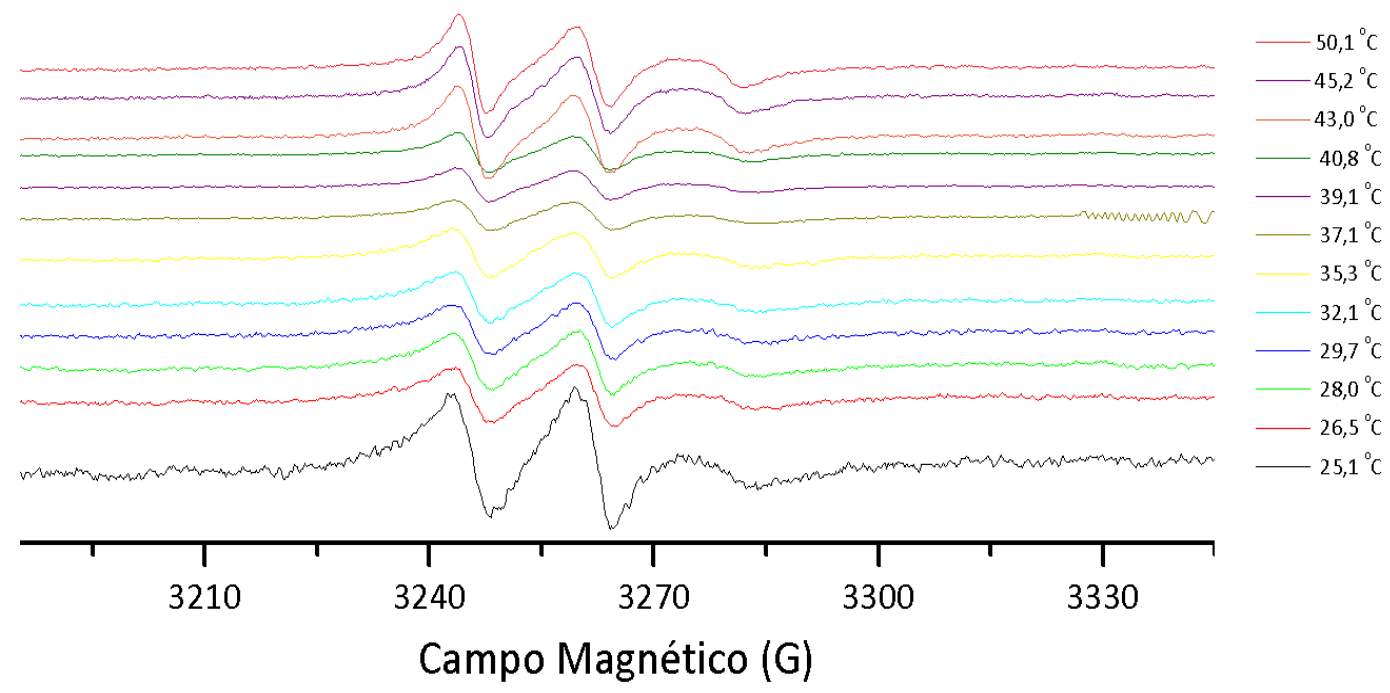

Figura 75 - Espectros de RPE em função da temperatura das modelos de membrana contendo DPPG e a sonda DOPTC na presença do complexo $\mathrm{Cu}(\mathrm{AG})(\mathrm{phen})$. Figura elaborada pela autora. 


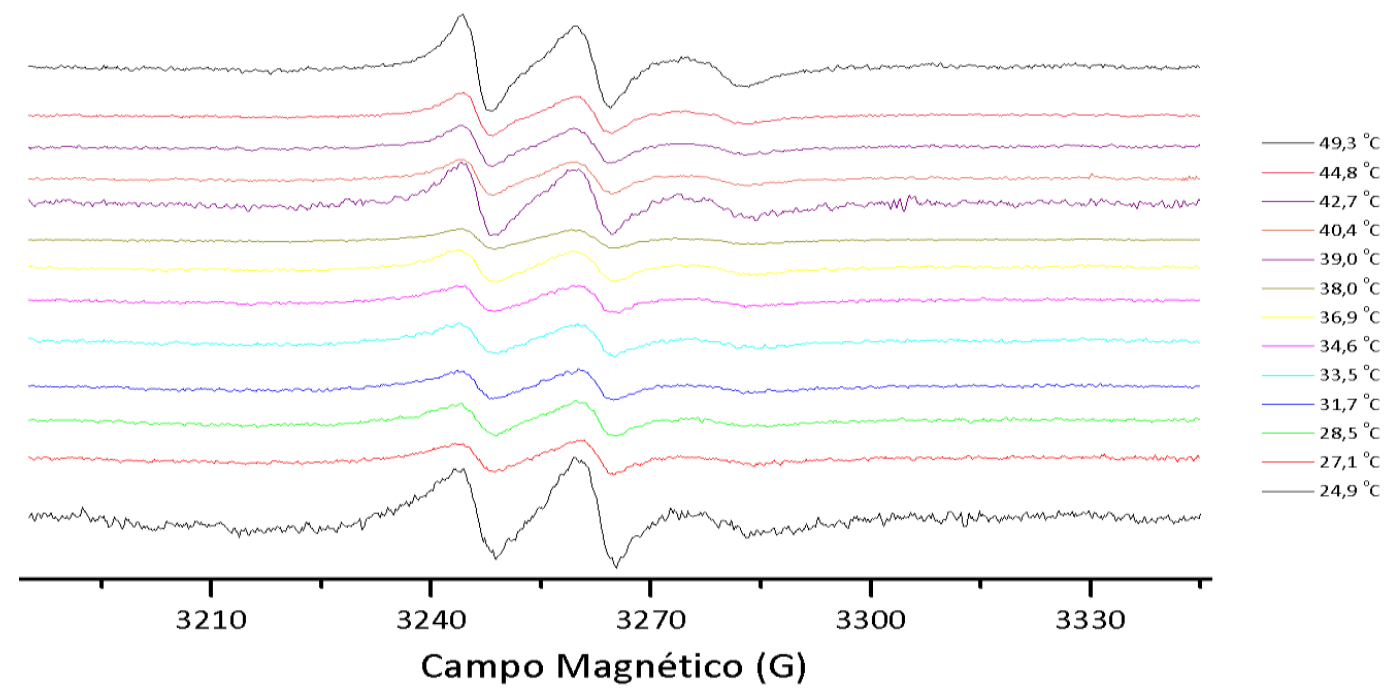

Figura 76 - Espectros de RPE em função da temperatura das modelos de membrana contendo DPPG e a sonda DOPTC na presença do complexo $\mathrm{Cu}(\mathrm{AP})($ phen). Figura elaborada pela autora.

\section{A3. Modelo de membrana: POPC}

Nesta seção apresentamos os espectros de RPE com o mimético de membrana POPc e as sondas 5, 7, 10, 12, 14 e 16-PCSL e DOPTC, na ausência e na presença dos compostos de interesse (Figuras 77-83). 


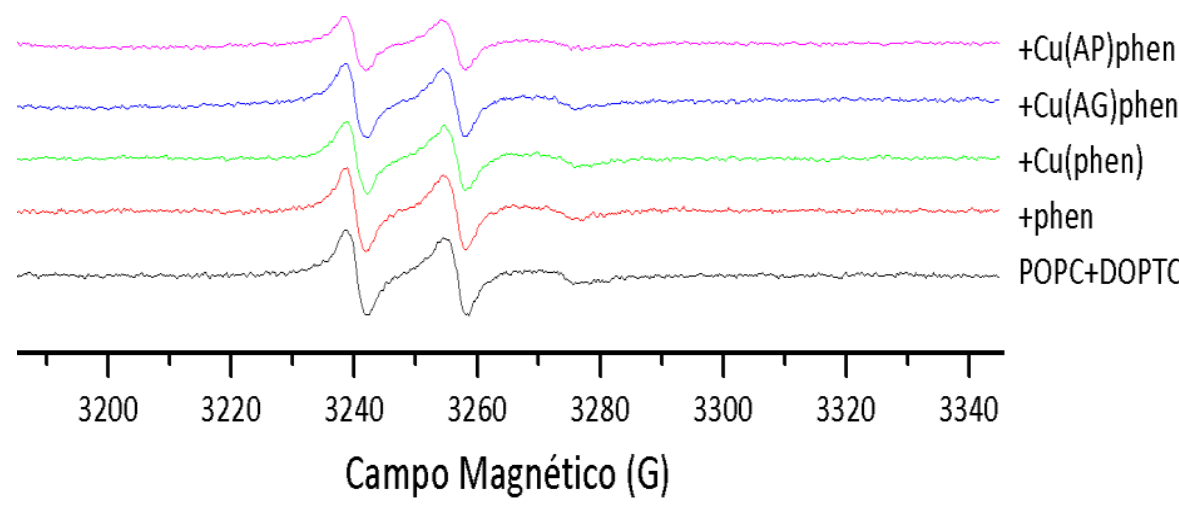

Figura 77 - Espectros de RPE do modelo de membrana contendo POPC e a sonda DOPTC na ausência e na presença das moléculas de estudo. Figura elaborada pela autora.

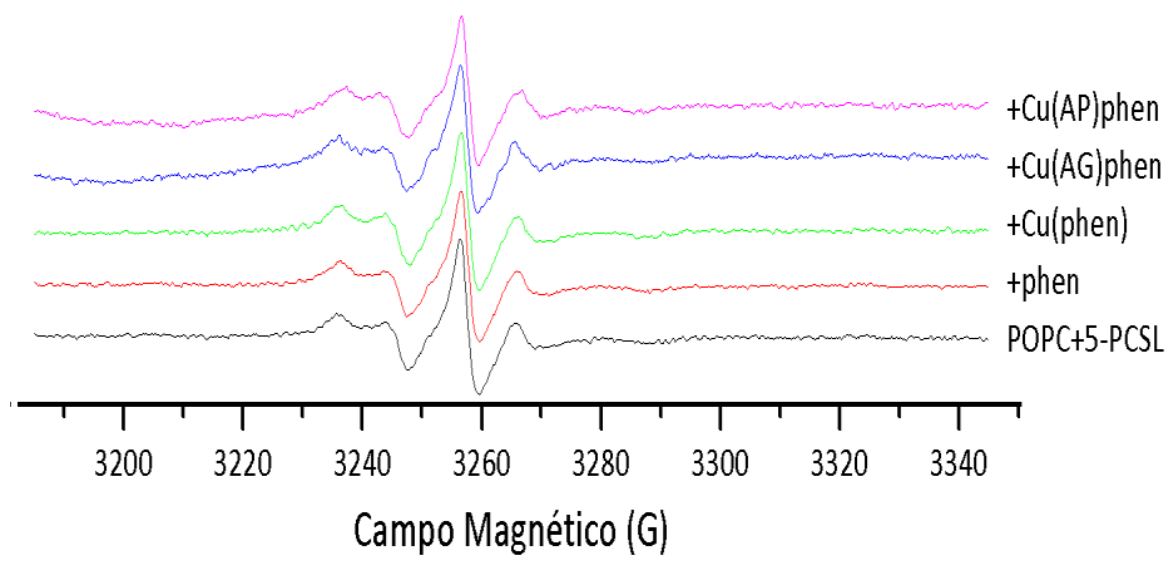

Figura 78 - Espectros de RPE do modelo de membrana contendo POPC e a sonda 5-PCSL na ausência e na presença das moléculas de estudo. Figura elaborada pela autora. 


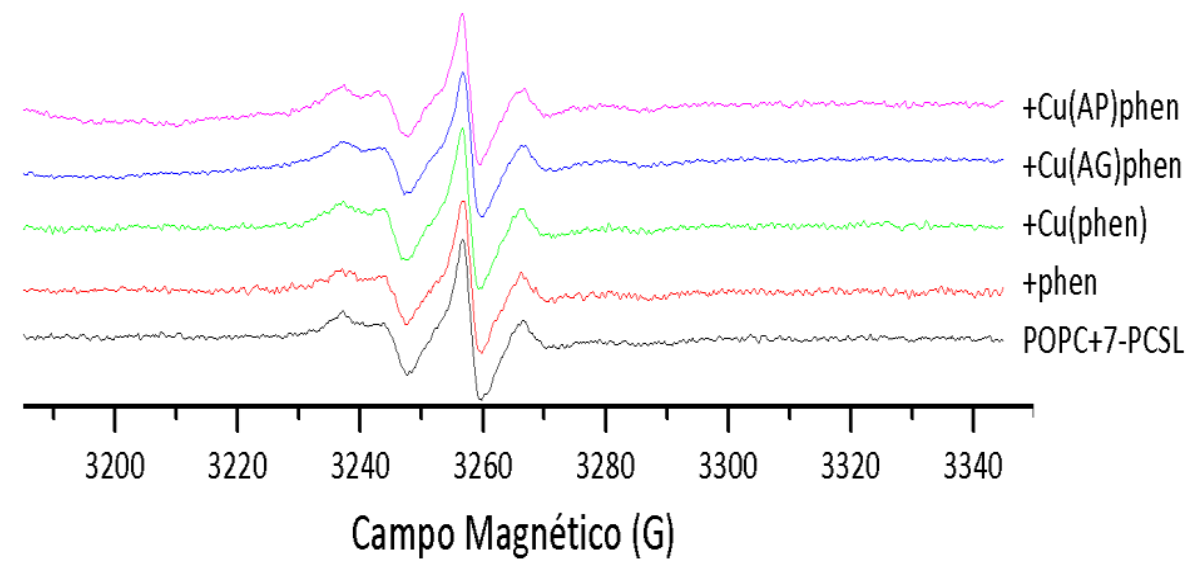

Figura 79 - Espectros de RPE do modelo de membrana contendo POPC e a sonda 7-PCSL na ausência e na presença das moléculas de estudo. Figura elaborada pela autora.

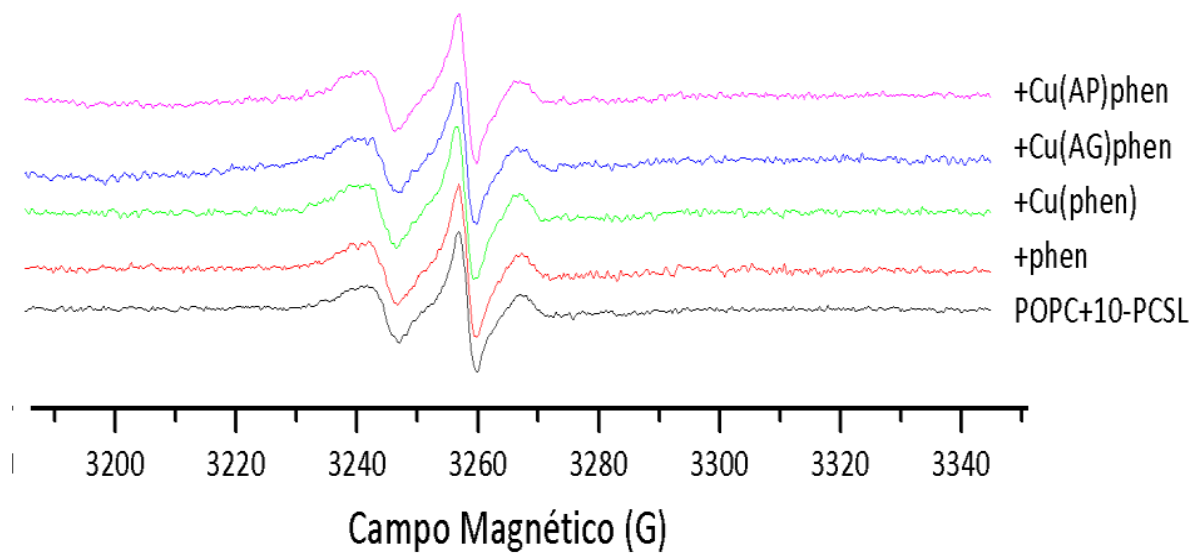

Figura 80 - Espectros de RPE do modelo de membrana contendo POPC e a sonda 10-PCSL na ausência e na presença das moléculas de estudo. Figura elaborada pela autora.

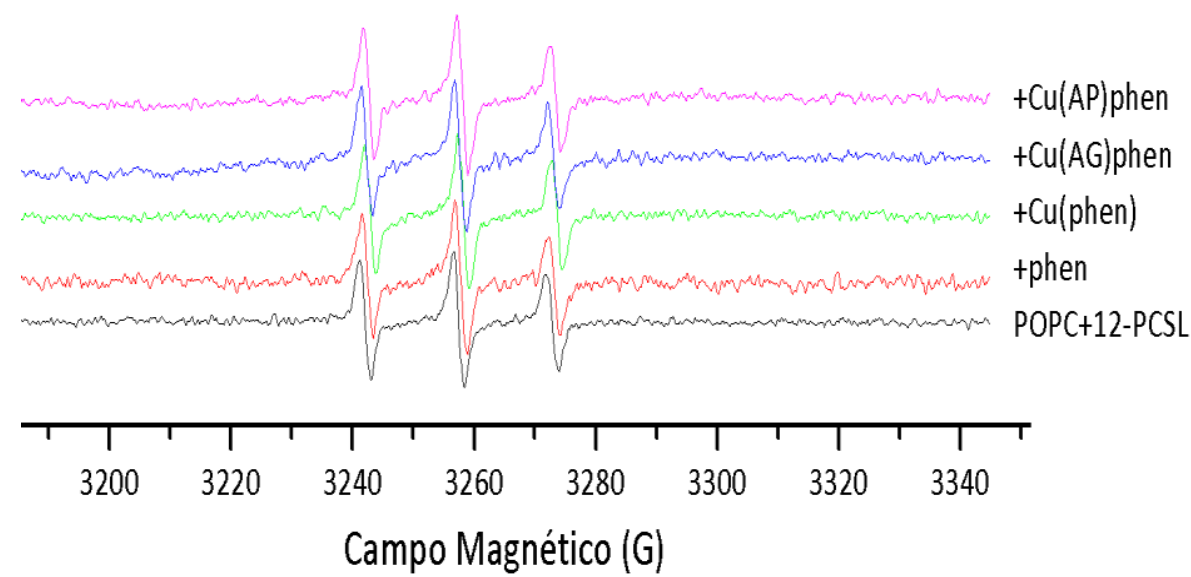

Figura 81 - Espectros de RPE do modelo de membrana contendo POPC e a sonda 12-PCSL na ausência e na presença das moléculas de estudo. Figura elaborada pela autora. 


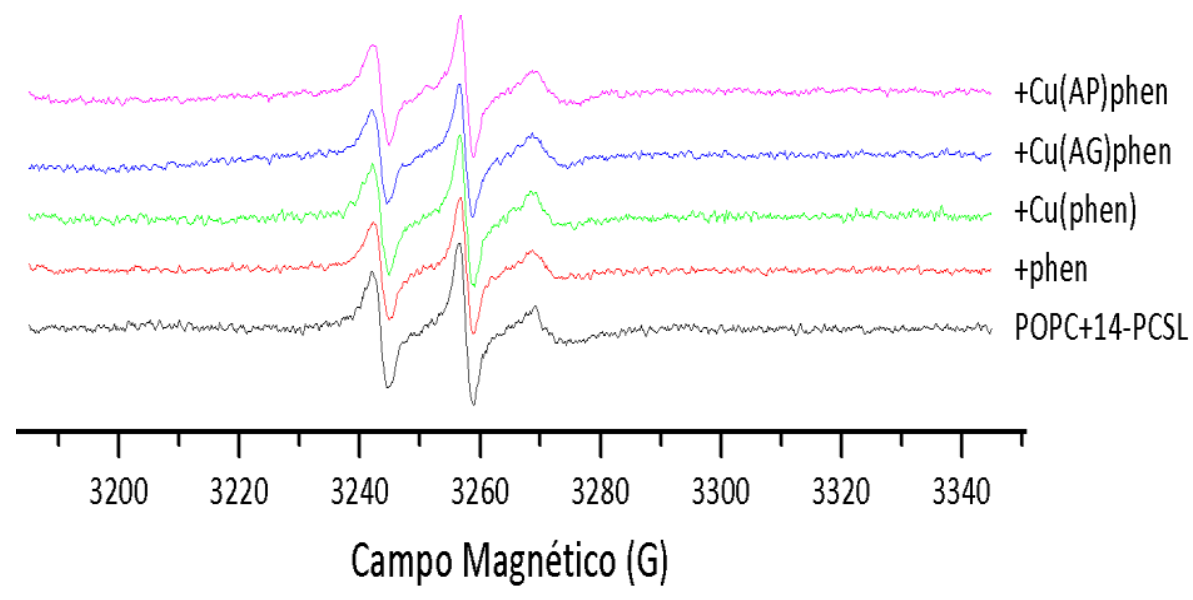

Figura 82 - Espectros de RPE do modelo de membrana contendo POPC e a sonda 14-PCSL na ausência e na presença das moléculas de estudo. Figura elaborada pela autora.

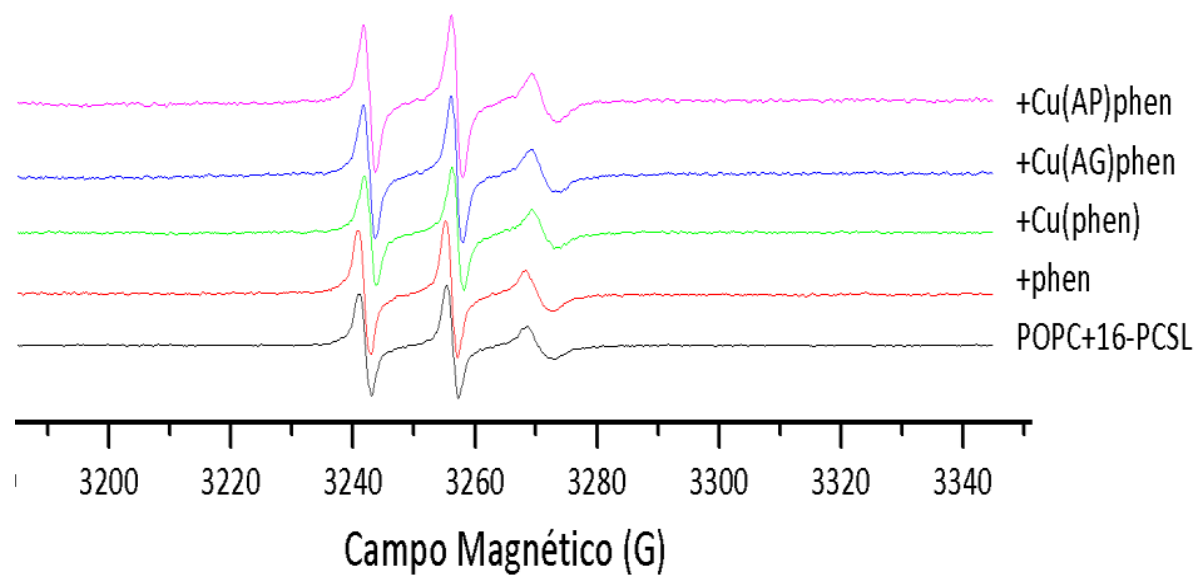

Figura 83 - Espectros de RPE do modelo de membrana contendo POPC e a sonda 16-PCSL na ausência e na presença das moléculas de estudo. Figura elaborada pela autora.

\section{A4. Modelo de membrana: POPG}

Nesta seção apresentamos os espectros de RPE com o mimético de membrana POPG e as sondas 5, 7, 10, 12, 14 e 16-PCSL e DOPTC, na ausência e na presença dos compostos de interesse (Figuras 84-90). 


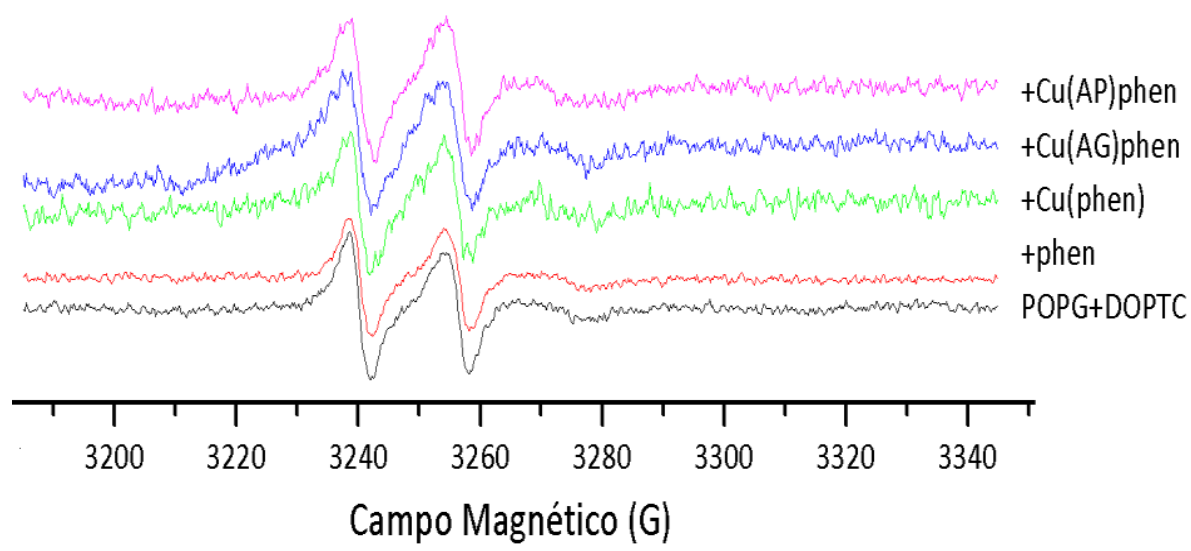

Figura 84 - Espectros de RPE do modelo de membrana contendo POPG e a sonda DOPTC na ausência e na presença das moléculas de estudo. Figura elaborada pela autora.

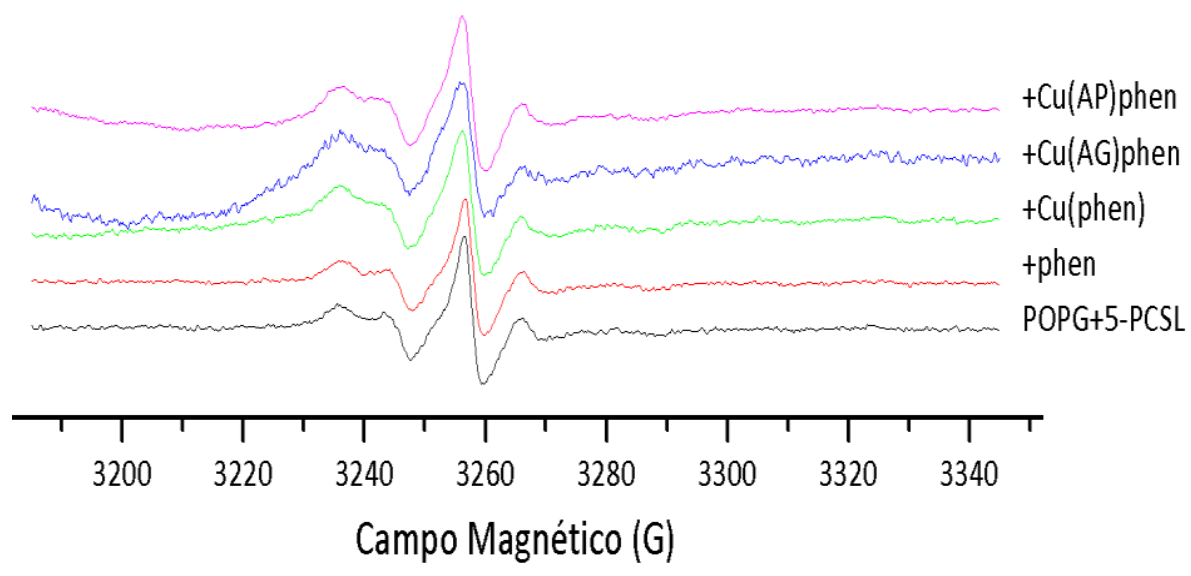

Figura 85 - Espectros de RPE do modelo de membrana contendo POPG e a sonda 5-PCSL na ausência e na presença das moléculas de estudo. Figura elaborada pela autora.

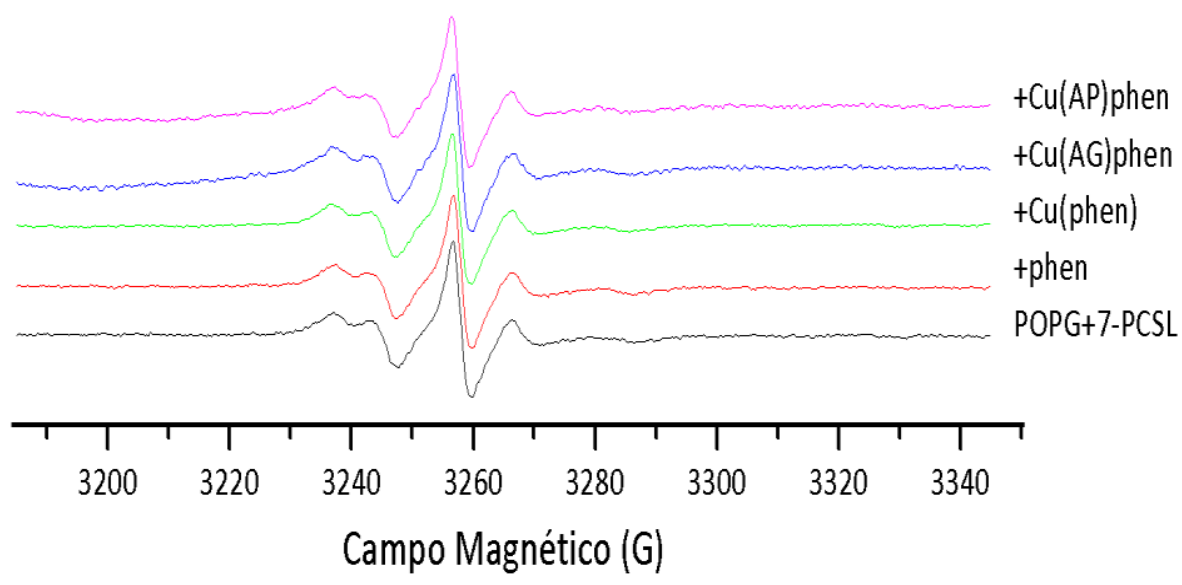


Figura 86 - Espectros de RPE do modelo de membrana contendo POPG e a sonda 7-PCSL na ausência e na presença das moléculas de estudo. Figura elaborada pela autora.

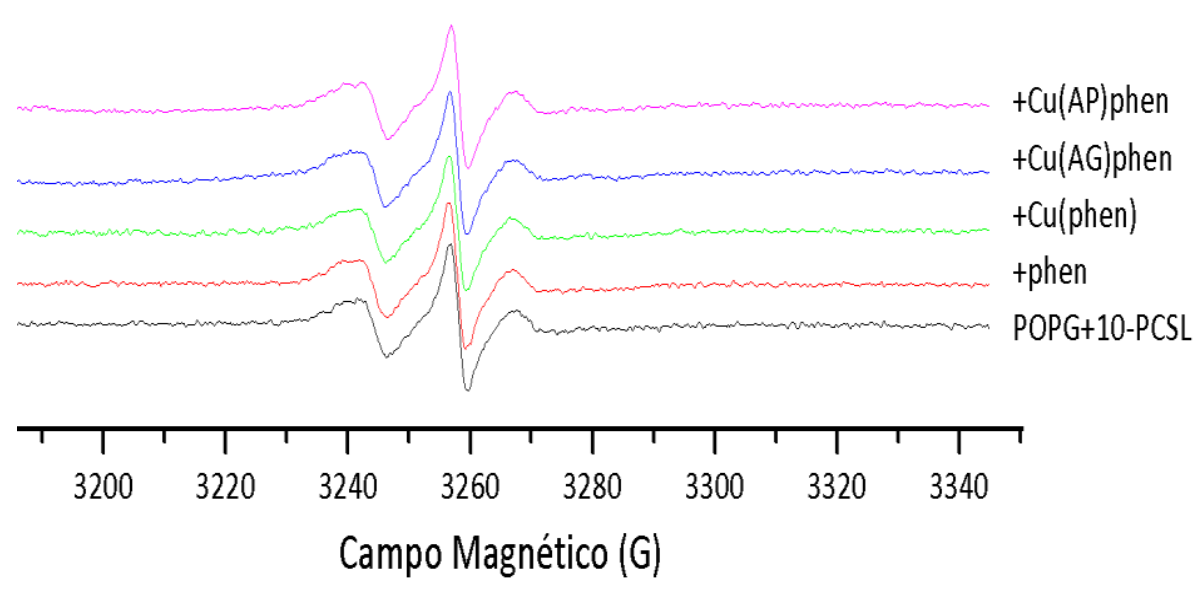

Figura 87 - Espectros de RPE do modelo de membrana contendo POPG e a sonda 10-PCSL na ausência e na presença das moléculas de estudo. Figura elaborada pela autora.

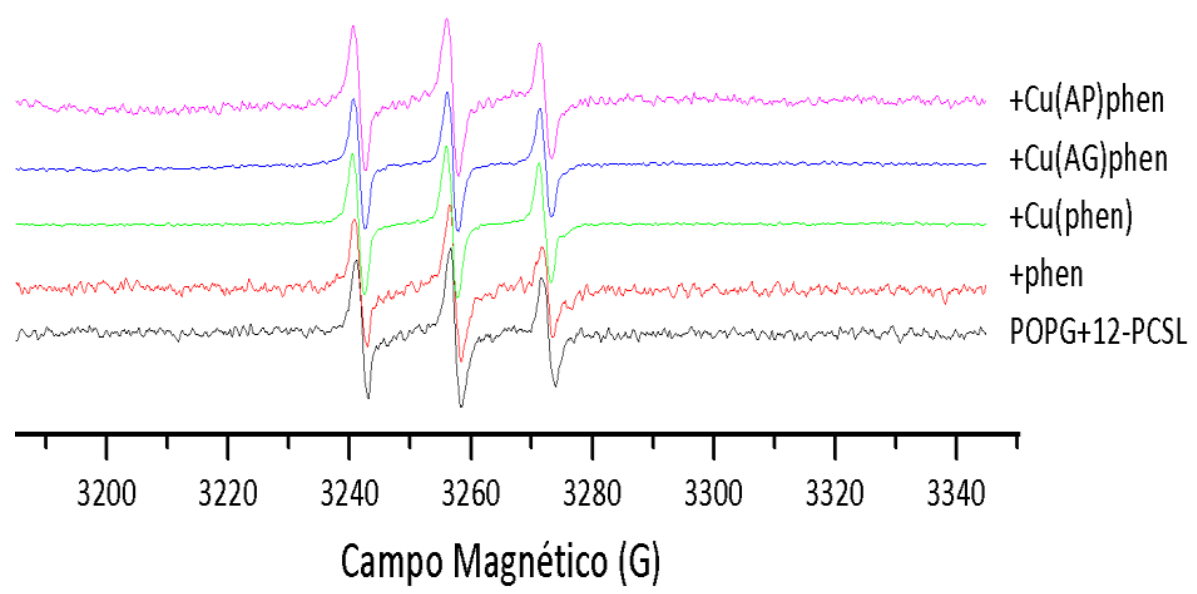

Figura 88 - Espectros de RPE do modelo de membrana contendo POPG e a sonda 12-PCSL na ausência e na presença das moléculas de estudo. Figura elaborada pela autora. 

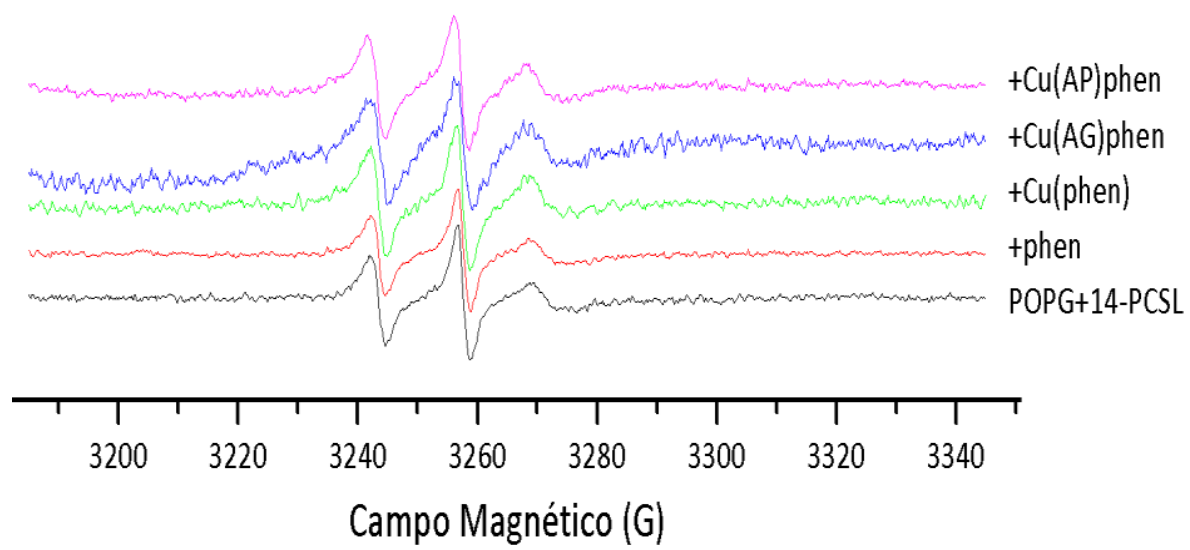

Figura 89 - Espectros de RPE do modelo de membrana contendo POPG e a sonda 14-PCSL na ausência e na presença das moléculas de estudo. Figura elaborada pela autora.

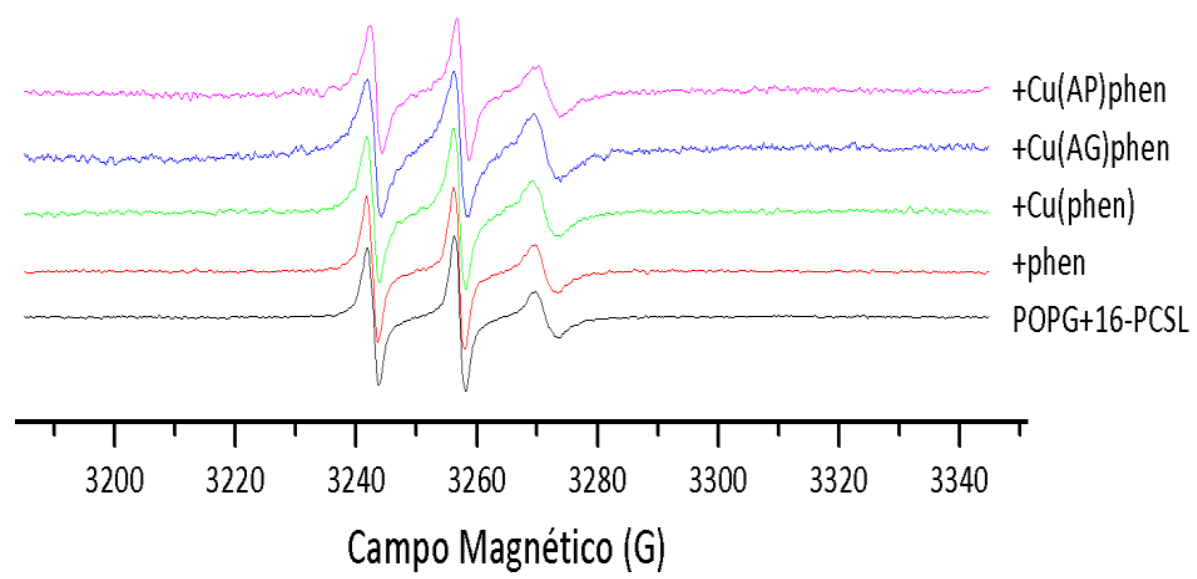

Figura 90- Espectros de RPE do modelo de membrana contendo POPG e a sonda 16-PCSL na ausência e na presença das moléculas de estudo. Figura elaborada pela autora. 